DOE/EIA-0582(97)

Distribution Category UC-950

\title{
The Effects of Title IV of the Clean Air Act Amendments of 1990 on Electric Utilities: An Update
}

\author{
March 1997
}

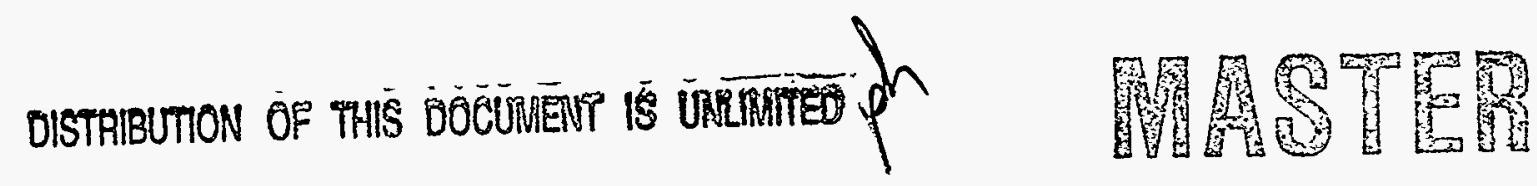

Energy Information Administration

Office of Coal, Nuclear, Electric and Alternate Fuels

U.S. Department of Energy

Washington, DC 20585

This report was prepared by the Energy Information Administration, the independent statistical and analytical agency within the Department of Energy. The information contained herein should not be construed as advocating or reflecting any policy position of the Department of Energy or of any other organization. 


\section{Contacts}

This report was prepared by the staff of the Coal and Electric Analysis Branch , Analysis and Systems Division, Office of Coal, Nuclear, Electric and Alternate Fuels. General information regarding this publication may be obtained from Robert M. Schnapp, Director, Analysis and Systems Division (202/426-1211, or e-mail at rschnapp@eia.doe.gov) or Betsy O'Brien, Chief, Coal and Electric Analysis Branch (202/426-1180, or e-mail at bobrien@eia.doe.gov). Specific questions regarding the preparation and content of the report should be directed to Art Fuldner, project manager (202/426-1125, or e-mail at afuldner@eia.doe.gov), or contributing authors Ronald Hankey (202/426-1188, or e-mail at rhankey@eia. doe.gov), William Liggett (202/426-1139, or e-mail at wliggett@eia.doe.gov), and Thelda McMillian (202/4261127, or e-mail at tmcmilli@eia.doe.gov). 


\section{DISCLAIMER}

Portions of this document may be illegible in electronic image products. Images are produced from the best available original document. 


\section{DISCLAIMER}

This report was prepared as an account of work sponsored by an agency of the United States Government. Neither the United States Government nor any agency thereof, nor any of their employees, make any warranty, express or implied, or assumes any legal liability or responsibility for the accuracy, completeness, or usefulness of any information, apparatus, product, or process disclosed, or represents that its use would not infringe privately owned rights. Reference herein to any specific commercial product, process, or service by trade name, trademark, manufacturer, or otherwise does not necessarily constitute or imply its endorsement, recommendation, or favoring by the United States Government or any agency thereof. The views and opinions of authors expressed herein do not necessarily state or reflect those of the United States Government or any agency thereof. 


\section{Preface}

Section 205(a)(2) of the Department of Energy Organization Act of 1977 (Public Law 95-91) requires the Administrator of the Energy Information Administration (EIA) to carry out a central, comprehensive, and unified energy data information program that will collect, evaluate, assemble, analyze, and disseminate data and information relevant to energy resources, reserves, production, demand, technology, and related economic and statistical information. To assist in meeting these responsibilities in the area of electric power, EIA has prepared this report, The Effects of Title IV of the Clean Air Act Amendments of 1990 on Electric Utilities: An Update.

Additional copies of this report can be downloaded from EIA's home page on the World Wide Web (http://www.eia.doe.gov). After contacting the home page, click on "Electricity" in Fuel Groups. This report will be listed in the "Publications" section. The "Applications" section can be reached by scrolling down through the "Data" section. From this point, the Clean Air Act browser can be downloaded. The browser has information about compliance activities, fuel shifts, emissions, allowance allocations, and scrubbers.

The legislation that created EIA vested the organization with an element of statutory independence. The EIA does not take positions on policy questions. Its responsibility is to provide timely, high-quality information and to perform objective, credible analyses in support of deliberations by both public and private decisionmakers, as well as by academia, the Congress, and the general public. Accordingly, this report does not purport to represent the policy positions of the U.S. Department of Energy or the Administration. 



\section{Contents}

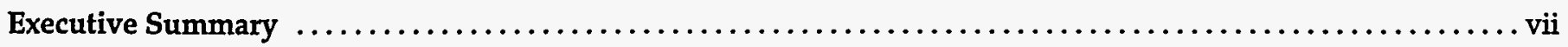

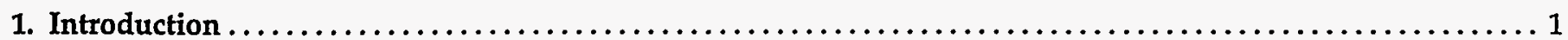

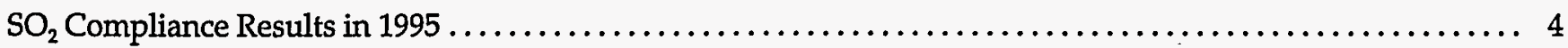

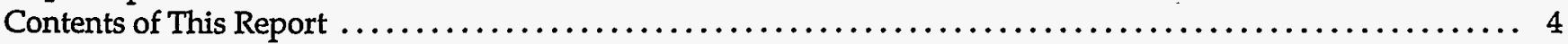

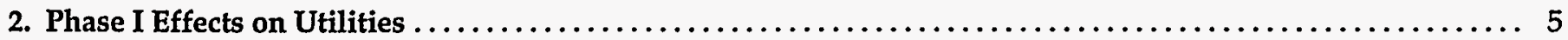

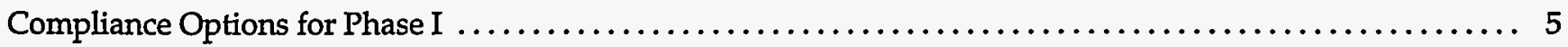

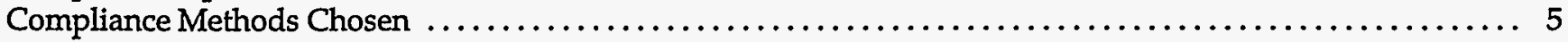

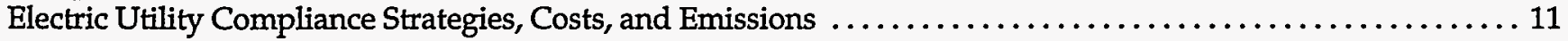

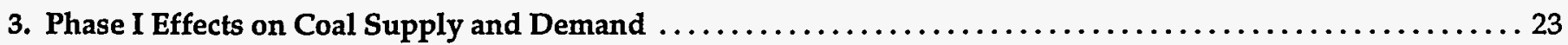

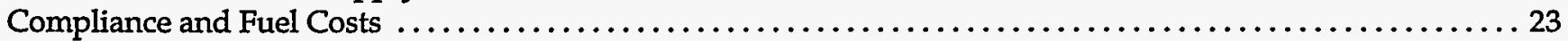

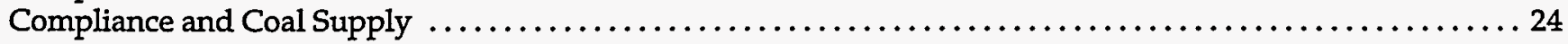

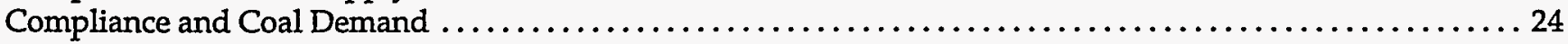

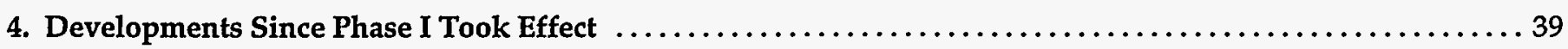

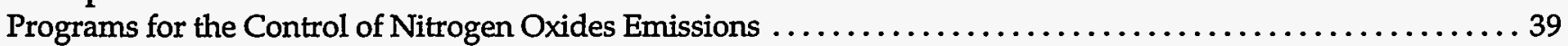

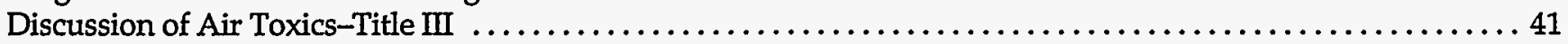

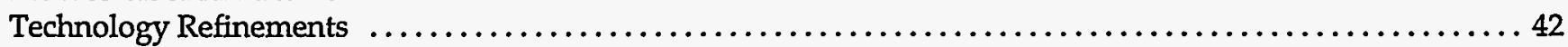

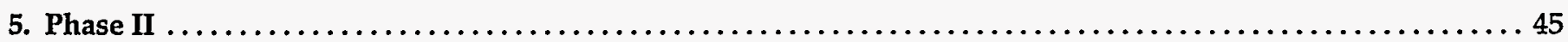

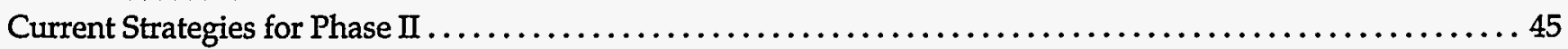

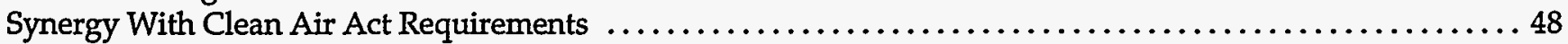

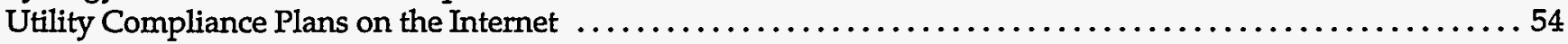

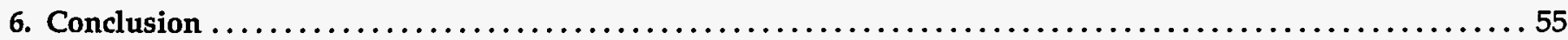

\section{Appendices}

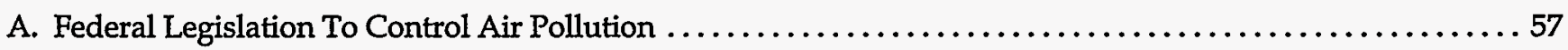

B. Profiles of the 261 Table 1 Generators Affected by Phase I (Table B1) and a Profile of the

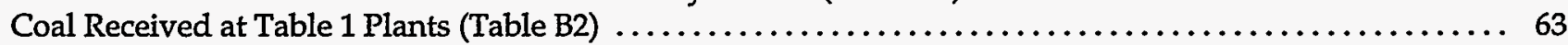

C. Cost and Characteristics of Selected Phase I Units, by Utility $\ldots \ldots \ldots \ldots \ldots \ldots \ldots \ldots \ldots \ldots \ldots \ldots \ldots$

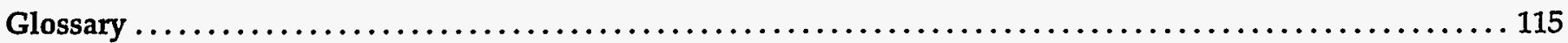


1. $\mathrm{SO}_{2}$ Emissions From Electric Utilities, 1985, 1990, 1994, and $1995 \ldots \ldots \ldots \ldots \ldots \ldots \ldots \ldots \ldots \ldots \ldots \ldots \ldots$

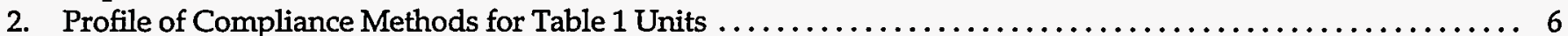

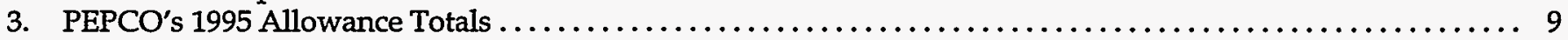

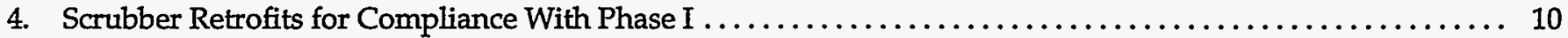

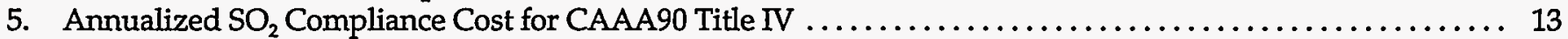

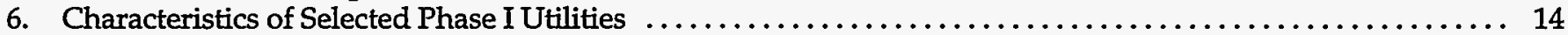

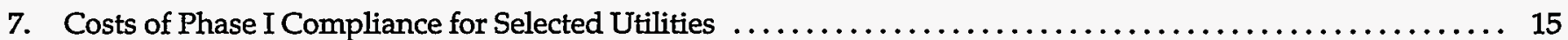

8. Costs and Quality of Fuels for Selected Electric Utility Phase I Plants, 1985, 1990, and $1995 \ldots \ldots \ldots \ldots \ldots 16$

9. Average Delivered Cost of Low-Sulfur Coal by Origin State, 1985, 1990, and $1995 \ldots \ldots \ldots \ldots \ldots \ldots . \ldots 23$

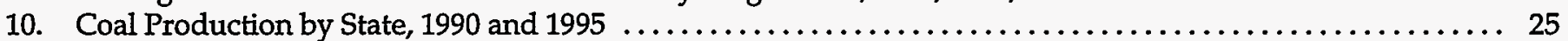

11. Coal Receipts at Electric Utility Plants by Supply Region and Sulfur Dioxide Level, 1990 and 1995 ....... 26

12. The Number of Mines and the Average Number of Miners Working Daily by State for 1990 and 1995 ..... 36

13. Phase II, Group 1 and Group 2 Boiler Statistics and Emission Limitations $\ldots \ldots \ldots \ldots \ldots \ldots \ldots \ldots \ldots \ldots \ldots$

14. Fossil Units Proposed for Repowering, 1996-2005, as of January $1,1996 \ldots \ldots \ldots \ldots \ldots \ldots \ldots \ldots \ldots . \ldots . \ldots . \ldots . \ldots$

15. U.S. Electric Utility Planned Coal-, Petroleum-, and Gas-Fired Capacity Retirements, 1996-2005,

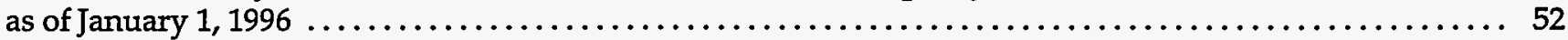

A1. Chronology of Historic Federal Legislation To Control Air Pollution $\ldots \ldots \ldots \ldots \ldots \ldots \ldots \ldots \ldots \ldots \ldots \ldots . \ldots \ldots$

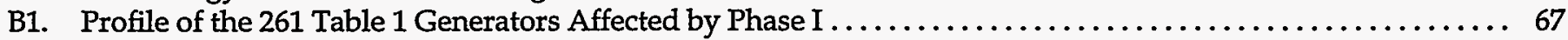

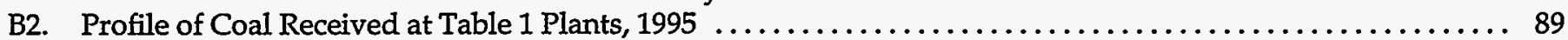

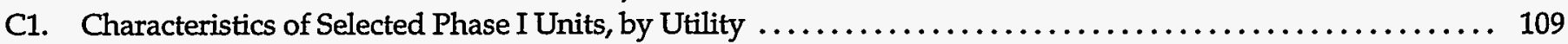

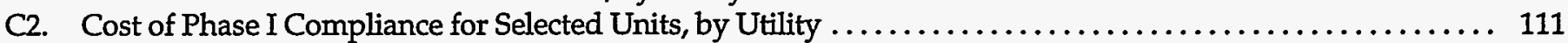

\section{Figures}

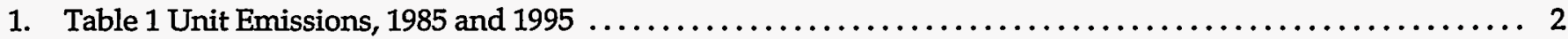

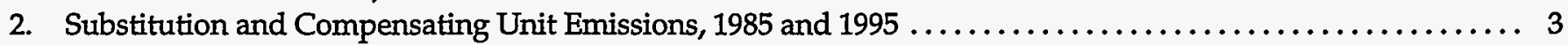

3. $1996 \mathrm{SO}_{2}$ Emission Allowance (Spot Market) Supply and Demand at the EPA Auction, March $1996 \ldots \ldots$.... 8

4. Cumulative Investments in Air Pollution Control Facilities by U.S. Major Investor-Owned Utilities,

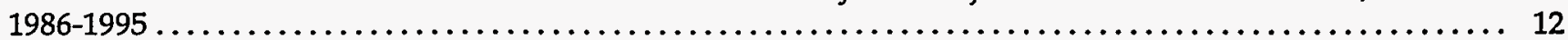

5. Total Investments in Air Pollution Control Facilities by Major Investor-Owned Utilities,

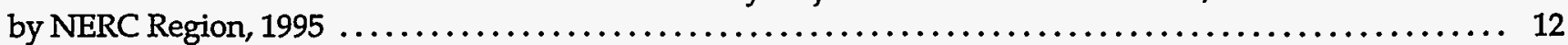

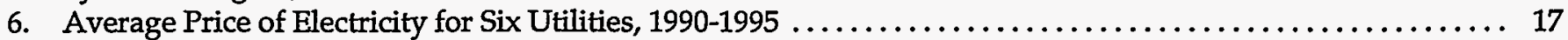

7. Coal Produced in Wyoming and Delivered to Electric Utilities, 1990 and $1995 \ldots \ldots \ldots \ldots \ldots \ldots \ldots \ldots \ldots \ldots$

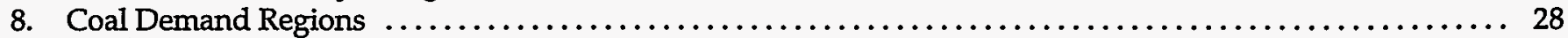

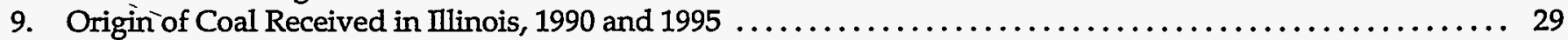

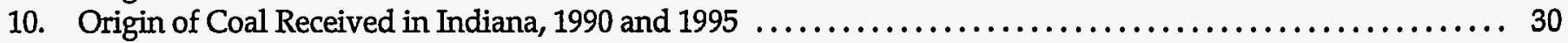

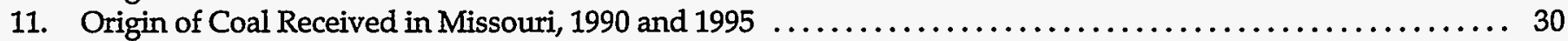

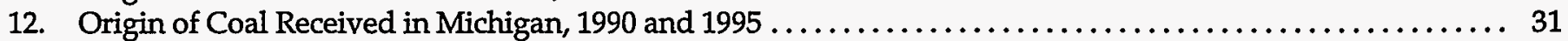

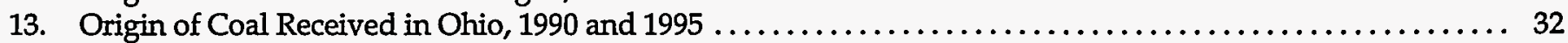

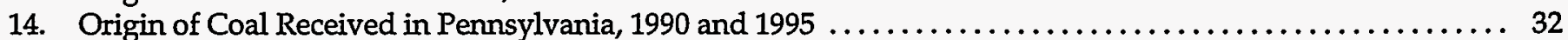

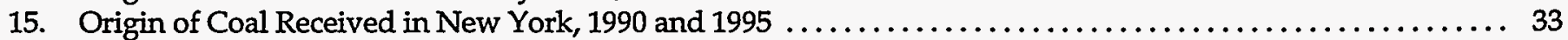

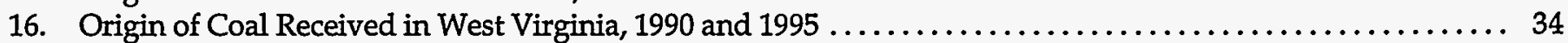

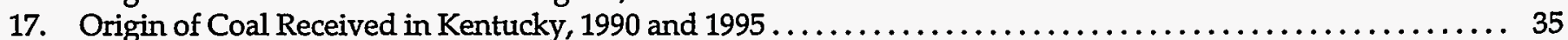

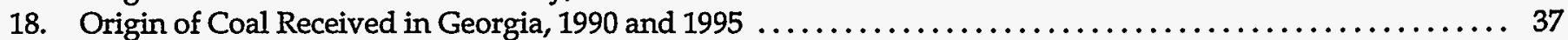

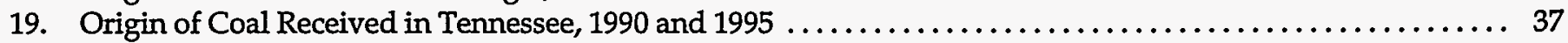

20. Average Age (Weighted by Capacity) of Fossil-Fuel Units, 1990, 2000, and 2010, as of January 1, $1996 \ldots \ldots 48$

21. Electric Power Regulations Timeline for Provisions Enacted Through the Clean Air Act ............. 53 


\section{Executive Summary}

The Clean Air Act Amendments of 1990 address numerous air quality problems in the United States that were not entirely covered in earlier legislation. One of these problems is acid rain caused by sulfur dioxide $\left(\mathrm{SO}_{2}\right)$ and nitrogen oxides $\left(\mathrm{NO}_{x}\right)$ emissions from fossil-fueled electric power plants and, to a lesser extent, from other industrial and transportation sources.

Title IV of the Act created a two-phased plan, administered by the U.S. Environmental Protection Agency (EPA), to reduce acid rain in the United States. Phase I runs from 1995 through 1999, and Phase II, which is more stringent than Phase I, begins in 2000. Title IV contains a table listing 261 generating units that are required to comply with Phase I. They are generally referred to by EPA as Table 1 units. Most of these units are coal fired with relatively high emissions. An additional 174 units are participating in Phase I based on the rules established by EPA, allowing a utility to designate substitution or compensating units as part of their Phase I compliance plans. ${ }^{1}$ Therefore, 435 units are now considered Phase I units. More than 2,000 units will be affected by Phase II.

This report updates and expands a report published by the Energy Information Administration in 1994 titled, Electric Utility Phase I Acid Rain Compliance Strategies for the Clean Air Act Amendments of 1990; it describes the strategies used to comply with the Acid Rain Program in 1995, the effect of compliance on $\mathrm{SO}_{2}$ emissions levels, the cost of compliance, and the effects of the program on coal supply and demand.

\section{$\mathrm{SO}_{2}$ Emissions Compliance Results in 1995}

The acid rain program allocated emissions allowances to Phase I units, authorizing them to emit one ton of $\mathrm{SO}_{2}$ for each allowance. Some utilities obtained additional allowances from three auctions and from bonus provisions in the Act. All 435 generating units had sufficient allowances to comply with Title $\mathrm{TV}$ in 1995. By complying with Title IV, Phase I units significantly reduced their $\mathrm{SO}_{2}$ emissions compared to previous years; they emitted 5.3 million tons of $\mathrm{SO}_{2}$ in 1995, 45 percent less than the 9.7 million tons emitted in 1990, and 34 percent lower than the 8.0 million tons emitted in 1994. In contrast, non-Phase I units emitted 6.6 million tons in 1995, 12 percent higher than the 5.9 million tons they emitted in 1990, and 5 percent higher than the 6.3 million tons they emitted in 1994.

\section{Estimated $\mathrm{SO}_{2}$ Compliance Costs}

Industry-wide annualized compliance costs are estimated at $\$ 836$ million (1995 dollars). These costs represent only 0.6 percent of the $\$ 151$ billion electric operating expenses of investor-owned utilities in 1995. Using scrubbers is estimated to cost $\$ 322$ per ton of $\mathrm{SO}_{2}$ removal and is the most expensive compliance method. Modifying a high sulfur bituminous coal-fired plant to burn lower sulfur subbituminous coal, which is estimated to cost $\$ 113$ per ton of $\mathrm{SO}_{2}$ removal, is the least expensive.

\section{Compliance Methods Used by Table 1 Units in 1995}

A utility could use one or more of the following compliance methods: (1) fuel switching and/or fuel blending with lower sulfur coal, (2) obtaining additional allowances, (3) installing flue gas desulfurization equipment (i.e., scrubbers), (4) using previously implemented emissions controls, (5) retiring units, (6) boiler repowering, (7) substituting Phase II units for Phase I units, and (8) compensating Phase I units with Phase II units. Most utilities (52 percent of Table I units) used fuel switching and blending in 1995 (Figure ES1). This method accounted for 59 percent of the reduction in $\mathrm{SO}_{2}$ emissions in 1995 compared to 1985 (Figure ES2). Competitive prices of lower sulfur coal, low shipping costs, lower than expected

\footnotetext{
1 Phase I affects 435 generating units powered by 445 boilers. Title IV states that 261 generating units are to be covered in Phase I of the program as Table A units (subsequently referred to in EPA's regulations as Table 1 units). These 261 generators are attached to 263 boiler units. Miami Fort generator 5 has two boilers. R.E. Burger generator 3 has two boilers. Similarly, the 182 boilers brought into Phase I as substitution and compensating units are attached to 174 generators.
} 
Figure ES1. Compliance Methods Used by Table 1 Units in 1995

(Percent of Table 1 Units)

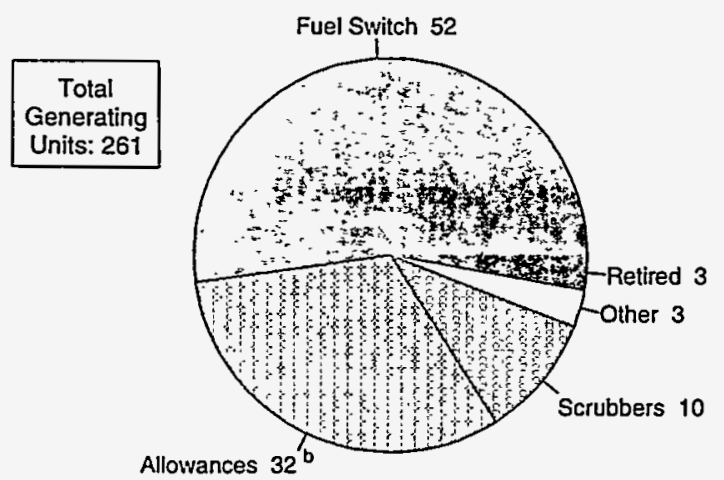

\footnotetext{
${ }^{a}$ Does not include 174 substitution and compensating units.

Includes switching to natural gas or petroleum and repowering.

Source: Energy Ventures Analysis, Inc., The Utility Report, December 1995.
}

costs for boiler modifications, and little deterioration in plant performance with lower sulfur coal were the reasons most utilities switched to lower sulfur coal. Also, because the industry is restructuring for competition, some utilities are reluctant to commit funds for more expensive solutions. For instance, scrubbers, which are relatively expensive, were chosen by only 10 percent of Table 1 units.

\section{Effects of Compliance on Regional Coal Supply and Demand}

Because fuel switching has been the compliance method used by most utilities, lower sulfur coal sales in the United States have increased substantially. In 1990, for example, low-to-medium sulfur coal accounted for 67 percent of total coal receipts at electric utilities, increasing to 77 percent by 1995 (Figure ES3). This switch to lower sulfur coal has affected regional coal distribution patterns. Between 1990 and 1995, sales of low-to-medium sulfur coal from the Powder River basin (Wyoming and Montana) increased by 78 million tons; sales from the central Appalachian region (Virginia, eastern Kentucky, and southern West Virginia) increased by 15 million tons; and sales from the Rocky Mountains (Colorado and Utah), increased by 10 million tons. In contrast, for the same period, sales of higher sulfur coal from the northern Appalachian region (Maryland, Pennsylvania, Ohio, and
Figure ES2. $\mathrm{SO}_{2}$ Reductions by Compliance Method at Table 1 Units in $1995^{\circ}$ (Percent of $\mathrm{SO}_{2}$ Reductions)

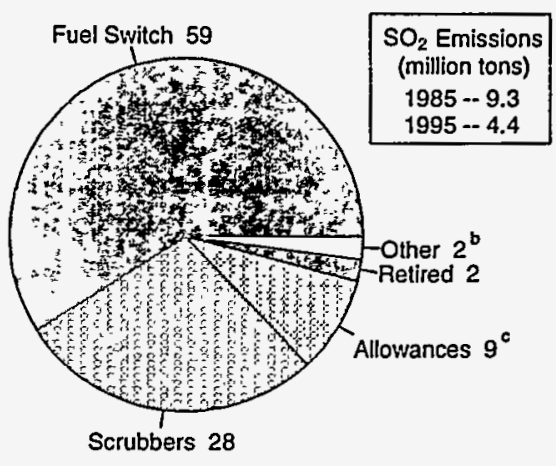

aDoes not include 174 substitution and compensating units.

b Includes switching to natural gas or petroleum and repowering.

Nine percent of the $1995 \mathrm{SO}_{2}$ emissions reductions were at units that used allowances as their compliance method. The average sulfur content of coal consumed by these units was reduced by 16 percent from 1985 to 1995 .

$\mathrm{SO}_{2}=$ Sulfur dioxide.

Note: Percent reductions of $\mathrm{SO}_{2}$ emissions were computed using 1985 as the base year.

Source: 1985 Emissions: U.S. Environmental Protection Agency, National Allowance Data Base, Version 2.11 (January 1993). 1995 Emissions: Acid Rain Division, U.S. Environmental Protection Agency.

northern West Virginia) decreased 29 million tons; and sales from the Illinois basin (Illinois, Indiana, and Western Kentucky) decreased by 40 million tons.

\section{Compliance Strategies and Costs of Six Utilities}

Compliance strategies and costs were examined in detail for six utilities with a total of 71 units (22.8 gigawatts of generating capacity) affected by Phase I. Most of the units were switched to lower sulfur coal to meet their $\mathrm{SO}_{2}$ emissions limitations. A few scrubbers were installed, but they were expensive relative to other compliance strategies. Substitution units, which in most instances generated extra emissions allowances, were used extensively by these utilities. Although the compliance costs represented a relatively small percentage of the utilities' total costs, the costs varied widely among the six. Average costs for $\mathrm{SO}_{2}$ and $\mathrm{NO}_{x}$ controls and continuous emissions monitoring systems ${ }^{2}$ ranged from a low of $\$ 16.39$ per

2 Continuous emissions monitors were required to be operational on November 15, 1993 for Phase I units and on January 1, 1995 for Phase II units (with the exception of $\mathrm{NO}_{\mathbf{x}} / \mathrm{CO}_{2}$ at oil- and gas-fired units). 
Figure ES3. U.S. Coal Receipts at Electric Utility Plants by Sulfur Level, 1990 and 1995 (Percent)

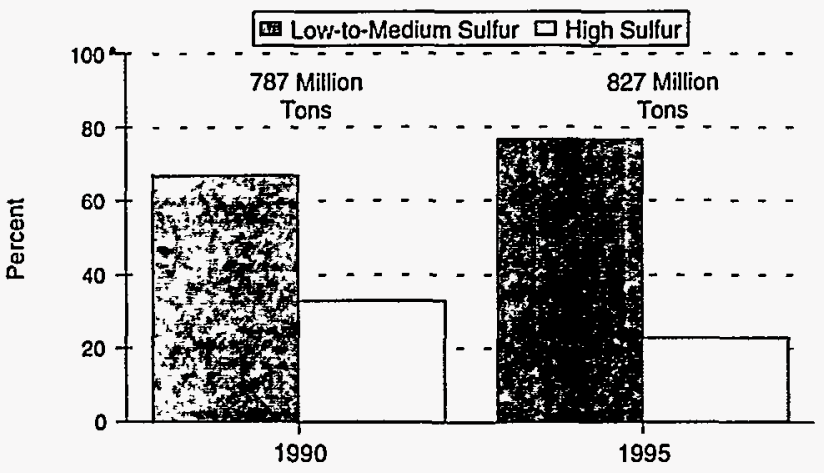

Note: High sulfur level is greater than 2.5 pounds of sulfur per million Btu. Low-to-medium sulfur level is less than or equal to 2.5 pounds of sulfur per million Btu.

Source: Federal Energy Regulatory Commission, Form 423, "Monthly Report of Cost and Quality of Fuels for Electric Plants."

kilowatt at Cincinnati Gas \& Electric to $\$ 208.90$ per kilowatt at Southern Indiana Gas and Electric Company.

Annual operation and maintenance costs (which in this analysis are primarily allowance purchases) ranged from a high of $\$ 19.4$ million at Illinois Power to a low of $\$ 1.8$ million at Potomac Electric Power Company. Depreciating capital costs over 15 years results in annual capital costs ranging from just over $\$ 1$ to almost $\$ 14$ per kilowatt of Phase I capacity.

\section{Phase II Compliance Strategies}

To meet stronger emissions limits under Phase II, some utilitiesare planning ahead by overcomplying in Phase I. For example, some utilities are installing scrubbers now instead of using a less expensive option. Many utilities have not finalized their Phase II compliance plans. One survey of 116 utilities conducted by the Industrial Information Services Company found that 41 percent of the respondents will switch fuels for Phase II and 28 percent will acquire additional emission allowances. For many utilities, fuel switching has proved to be the most cost-effective choice in Phase I, and many of them will probably continue this strategy in Phase II. For utilities selecting allowances as a strategy for Phase II, extra allowances can be obtained from numerous sources.

Utilities receiving extra allowances for installing scrubbers or for complying earlier than required are selling some of their allowances at relatively low prices. Some higher sulfur coal producers have bundled emissions allowances with their sales to help maintain their customer base. It is estimated that only 12 to 20 gigawatts of capacity may be scrubbed to comply with Phase II because a number of utilities that had originally planned to install scrubbers have either deferred installation, or canceled them in favor of fuel switching or purchasing allowances. 


\section{Introduction}

The Clean Air Act Amendments of 1990 (CAAA90), Public Law 101-549, are the latest revisions to the Clean Air Act. Among the numerous provisions of CAAA90 is Title IV, which requires the U.S. Environmental Protection Agency (EPA) to establish the Acid Rain Program to reduce the adverse effects of acidic deposition popularly known as acid rain. Acid rain is formed largely from emissions of sulfur dioxide $\left(\mathrm{SO}_{2}\right)$ and nitrogen oxides $\left(\mathrm{NO}_{x}\right)$ that are emitted primarily by fossil-fueled electric power plants, other industrial sources, and transportation sources. The $\mathrm{SO}_{2}$ reduction provisions of Title IV of the CAAA90 (hereafter referred to as Title IV) are noteworthy and creative because they represent the first large-scale attempt to set overall emissions levels by using marketable licenses (allowances) and a choice of compliance methods to control emissions rather than using regulations that specify what actions must be undertaken (command and control). An allowance permits the emission of 1 ton of $\mathrm{SO}_{2}$. Title $\mathrm{IV}$ gives electric utilities several options for reducing emissions, thus introducing flexibility into compliance plans. Because they have several compliance options, many utilities have alternative plans for complying with the Acid Rain Program, depending on the circumstances (Table B1 of Appendix B).

Title IV requires a two-phase tightening of the restrictions placed on fossil-fuel fired power plants. Phase I, from 1995 through 1999, and Phase II, starting in 2000. Phase I mostly affects those power plants that are the largest sources of $\mathrm{SO}_{2}$ and $\mathrm{NO}_{x}$. Phase II will affect virtually all fossil-fueled electric power producers, including utilities and nonutilities. Phase II will tighten the annual emissions limits imposed on these large, higher emitting plants, and it will set restrictions on smaller plants fired by coal, oil, and natural gas. Most existing utility units with an output capacity of 25 megawatts or greater and virtually all new utility and nonutility units will be affected in Phase $I$. Also, other sources of $\mathrm{SO}_{2}$ (such as industrial facilities) may elect to participate in the Acid Rain $\mathrm{SO}_{2}$ Program. ${ }^{1}$
Title IV explicitly specifies 261 generating units powered by 263 boiler units at 110 utility plants for Phase $\mathrm{I}^{2}{ }^{2}$ These 261 units, located in 21 eastern and midwestern States, are referred to as "Table 1" units because they were explicitly identified in Table 1 of the regulation. However, because of provisions in Title IV that allow utilities to use other units to substitute or compensate for those originally specified, 174 additional generating units were affected by Phase I in 1995 (a total of 435 affected generating units) (Figures 1 and 2).

A boiler unit brought into Phase I as a substitution unit can assist a Table 1 boiler unit in meeting its emissions reductions obligations. Utilities may make cost-effective emissions reductions at the substitution unit instead of at the Table 1 unit by achieving the same overall emissions reductions that would have occurred without the participation of the substitution unit. After January 1, 1995, a Table 1 boiler unit may designate any Phase II boiler unit as a substitution unit only if both units are under the control of the same owner or operator. In 1995, 91 Table 1 boiler units designated 167 Phase $I$ boiler units to be substitution units. Of these 91 Table 1 boiler units, almost half were located in the Midwest and almost a quarter were located in the South. Also, almost a third of these Table 1 units designated substitution units that were located at the same plant. ${ }^{3}$ The other seven Phase II boiler units that participated in the Acid Rain Program in 1995 entered as compensating units. Table 1 units that reduced their utilization below their baseline may designate compensating units to provide compensating generation that would account for the reduced utilization of the Table 1 unit. A Table 1 unit may designate any Phase II unit as a compensating unit if the Phase II compensating unit is in the Table 1 unit's dispatch system or has a contractual agreement with the Table 1 unit, and if the emissions rate of the compensating unit has not declined substantially since 1985.

1 Environmental Protection Agency, Allowance System, Proposed Acid Rain Rule, 400/1-91/034 (Washington, DC, December 1991 ), p.1.

${ }^{2}$ Phase I affects 445 boiler units that are associated with 435 generating units. CAAA90 explicitly states that 261 generating units are to be covered in Phase I of the program as Table A units (subsequently referred to in EPA's regulations as Table 1 units). These 261 generators are attached to 263 boilers. Miami Fort generator 5 has two boilers. R.E. Burger generator 3 has two boilers. Similarly, the 182 boilers brought into Phase I as substitution and compensating units are attached to 174 generators. Boilers are referred to throughout the report because $\mathrm{SO}_{2}$ is released into the atmosphere by burning fuel in boilers and allowances are deducted from accounts based on boiler emissions.

3 Environmental Protection Agency, 1995 Compliance Results, Acid Rain Program, EPA/430-R-96-012 (Washington, DC, July 1996 ), p. 1. 
Figure 1. Table 1 Unit Emissions, 1985 and 1995

(Tons of $\mathrm{SO}_{2}$ )

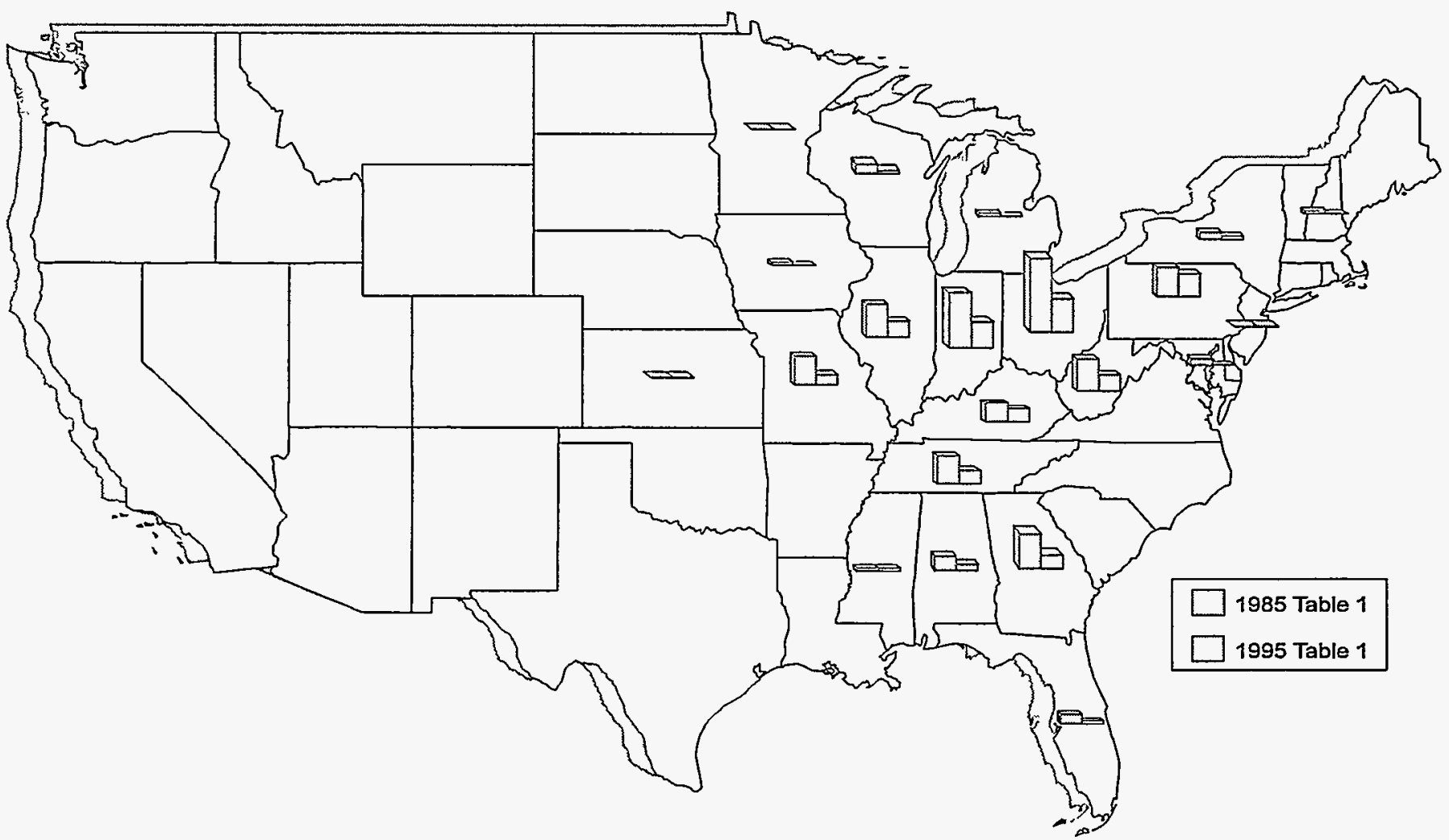

\begin{tabular}{l|c|c|l|c|c}
\hline \multicolumn{1}{c|}{ State } & $\begin{array}{c}1985 \text { Table 1 } \\
\text { Unit Emissions } \\
\text { Estimates }\end{array}$ & $\begin{array}{c}\text { 1995 Table 1 } \\
\text { Unit Emissions } \\
\text { (from CEMS) }\end{array}$ & State & $\begin{array}{c}\text { 1985 Table 1 } \\
\text { Unit Emissions } \\
\text { Estimates }\end{array}$ & $\begin{array}{c}\text { 1995 Table 1 } \\
\text { Unit Emissions } \\
\text { (from CEMS) }\end{array}$ \\
\hline Alabama & 297,195 & 132,645 & Mississippi & 83,365 & 56,621 \\
Florida & 224,089 & 108,552 & Missouri & 746,219 & 227,525 \\
Georgia & 795,476 & 276,004 & New Hampshire & 52,535 & 36,128 \\
Illinois & 766,492 & 392,177 & New Jersey & 33,735 & 21,720 \\
Indiana & $1,268,745$ & 636,502 & New York & 173,882 & 70,486 \\
lowa & 73,873 & 27,389 & Ohio & $1,711,128$ & 770,357 \\
Kansas & 3,167 & 2,893 & Pennsylvania & 671,216 & 515,804 \\
Kentucky & 461,023 & 320,074 & Tennessee & 621,923 & 287,446 \\
Maryland & 133,081 & 119,804 & West Virginia & 715,483 & 372,971 \\
Michigan & 59,017 & 13,171 & Wisconsin & 220,387 & 54,669 \\
Minnesota & 2,033 & 1,493 & Total & $9,114,064$ & $4,444,431$ \\
\hline
\end{tabular}

CEMS = Continuous Emissions Monitoring System.

Note: Totals may not equal sum of components because of independent rounding.

Source: 1995: U.S. Environmental Protection Agency, State Summary Data for 445 Phase I Boilers, http://www.epa.gov/ acidrain/comprpt/statesum.html. 1985: Energy Information Administration, Form EIA-867, "Steam-Electric Plant Operation and Design Report." 
Figure 2. Substitution and Compensating Unit Emissions, 1985 and 1995

(Tons of $\mathrm{SO}_{2}$ )

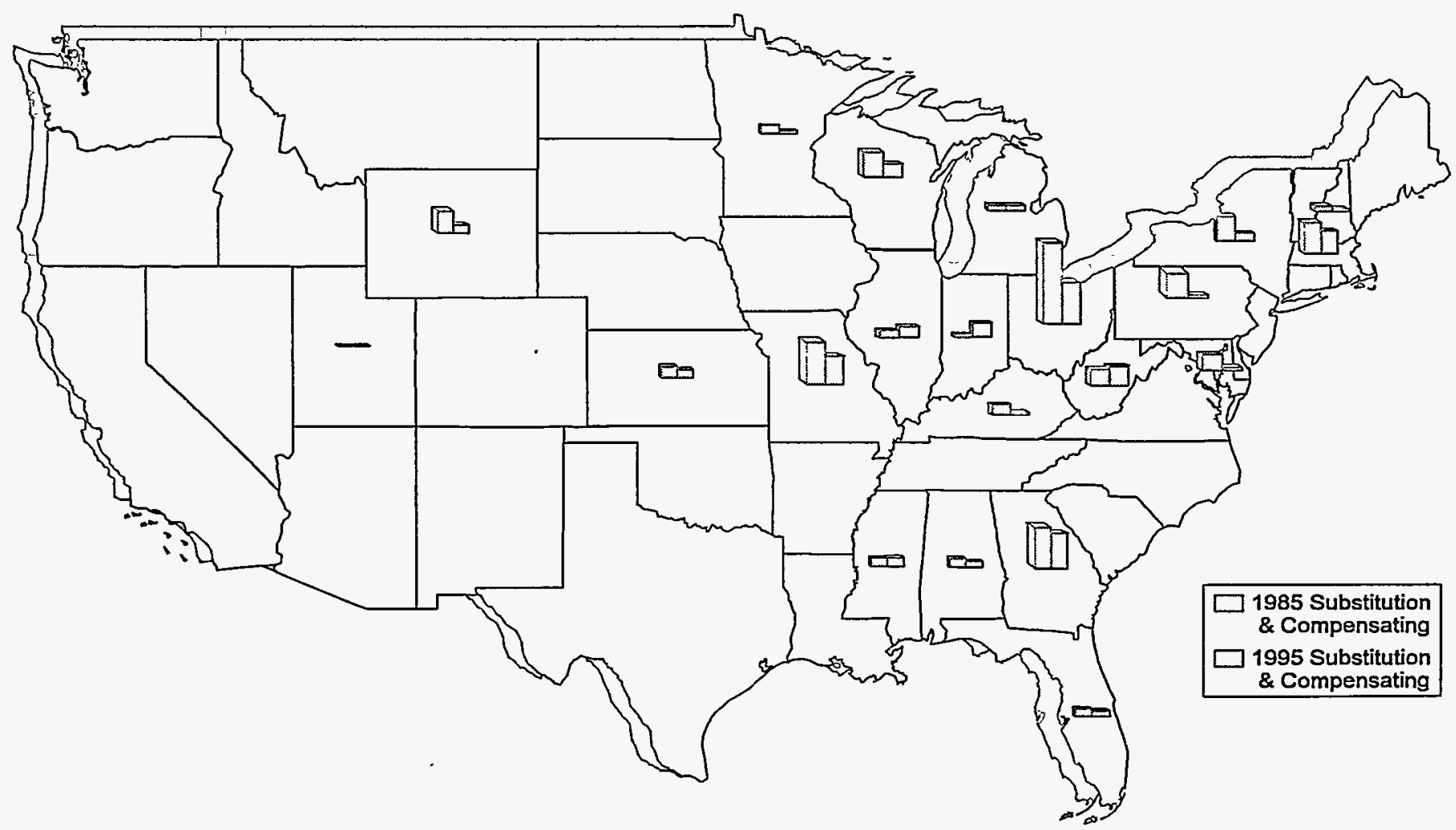

\begin{tabular}{l|c|c|l|c|c}
\hline \multicolumn{1}{c|}{ State } & $\begin{array}{c}1985 \text { Substitution } \\
\text { and } \\
\text { Compensating } \\
\text { Unit Emissions } \\
\text { Estimates }\end{array}$ & $\begin{array}{c}\text { 1995 Substitution } \\
\text { and } \\
\text { Compensating } \\
\text { Unit Emissions } \\
\text { (from CEMS) }\end{array}$ & State & $\begin{array}{c}\text { 1985 Substitution } \\
\text { and } \\
\text { Compensating } \\
\text { Unit Emissions } \\
\text { Estimates }\end{array}$ & $\begin{array}{c}\text { 1995 Substitution } \\
\text { and } \\
\text { Compensating } \\
\text { Unit Emissions } \\
\text { (from CEMS) }\end{array}$ \\
\hline Alabama & 25,993 & 17,350 & Mississippi & 19,379 & 24,617 \\
Florida & 24,599 & 22,178 & Missouri & 140,386 & 98,522 \\
Georgia & 142,033 & 121,586 & New Hampshire & 14,265 & 11,155 \\
Illinois & 31,380 & 40,042 & New York & 88,686 & 25,340 \\
Indiana & 17,937 & 44,806 & Ohio & 281,233 & 140,635 \\
Kansas & 55,567 & 26,156 & Pennsylvania & 91,693 & 13,755 \\
Kentucky & 27,151 & 14,647 & Utah & 1,783 & 2 \\
Maryland & 15,806 & 6,018 & West Virginia & 59,975 & 63,914 \\
Massachusetts & 100,310 & 72,770 & Wisconsin & 87,069 & 52,411 \\
Michigan & 21,393 & 16,330 & Wyoming & 75,121 & 30,754 \\
Minnesota & 27,645 & 11,010 & Total & $1,349,404$ & 853,998 \\
\hline
\end{tabular}

CEMS $=$ Continuous Emissions Monitoring System.

Note: Totals may not equal sum of components because of independent rounding.

Source: 1995: U.S. Environmental Protection Agency, State Summary Data for 445 Phase I Boilers, http://www.epa.gov/ acidrain/comprptstatesum.html. 1985: Energy Information Administration, Form ElA-867, "Steam-Electric Plant Operation and Design Report." 
Some utilities designated Phase II units as substitution units during Phase I, instead of waiting for Phase II, to take advantage of the Phase $\mathrm{INO}_{\mathrm{x}}$ reductions requirements, which are less stringent than the Phase II requirements. If the utility determines that the benefits of less stringent $\mathrm{NO}_{\mathrm{x}}$ requirements outweigh the costs of more stringent $\mathrm{SO}_{2}$ requirements, substitution becomes more likely.

\section{$\mathrm{SO}_{2}$ Compliance Results in 1995}

During the past decade, utilities with Phase I units have achieved significant reductions in $\mathrm{SO}_{2}$ emissions, most notably in 1995, the first year of the program. During 1995, 435 Phase I units emitted 5.3 million tons of $\mathrm{SO}_{2}$ into the atmosphere. This amount was 50 percent lower than the estimated 10.5 million tons they emitted in 1985, and well below EPA's 1995 goal of 8.7 million tons for Phase I units (Table 1).

With coal prices decreasing, particularly lower sulfur coal, some industry observers have suggested that utilities would have switched to lower sulfur coal regardless of Title $\mathrm{IV}^{\prime} \mathrm{S} \mathrm{SO}_{2}$ emissions limits. To fully address this issue, however, would require a detailed analysis of regional low- and high-sulfur coal prices and other factors, which is beyond the scope of this report. An analysis at a broader level, however, suggests that Title IV has caused, at least in part, a reduction in $\mathrm{SO}_{2}$ emissions. While $\mathrm{SO}_{2}$ emissions from Phase I units have steadily decreased, $\mathrm{SO}_{2}$ emissions from nonaffected units have increased (Table 1). In 1985, Phase I units were the largest group of $\mathrm{SO}_{2}$ emitters, accounting for 67 percent of total $\mathrm{SO}_{2}$ emissions, and nonPhase I units accounted for 33 percent. By 1995, Phase I units emitted 45 percent of total $\mathrm{SO}_{2}$ emissions, whereas non-Phase I units accounted for 55 percent of the total.

\section{Contents of This Report}

In 1994, the Energy Information Administration released an analysis report titled, Electric Utility Phase I Acid Rain Compliance Strategies for the Clean Air Act Amendments of 1990. The material presented here updates that report and provides information on the strategies utilities are using to comply with $\mathrm{SO}_{2}$ and $\mathrm{NO}$ emissions reductions requirements during Phase I of Title IV of CAAA90, and provides estimates of the costs incurred by six utilities in implementing these strategies through 1995. The discussion covers four $\mathrm{SO}_{2}$ compliance strategies: (1) fuel switching and/or blending with lower sulfur coal, (2) obtaining additional allowances, (3) installing flue gas desulfurization equipment (scrubbers), and (4) other compliance strategies. The effects of these strategies on coal supply and demand are also examined. The report describes utilities' plans for Phase $I I$, although many utilities have adopted a wait-and-see approach, choosing to see how the market for allowances develops and how competition in the electric power industry progresses. A key component of this strategy involves the accumulation of excess Phase I allowances, which can be used at any point in the future. This strategy allows utilities to delay installation of pollution control equipment with high capital costs until after 2000. Also, the evolution of the electric power industry toward more competition has led many utilities to view their compliance plans for the future as proprietary; therefore, they are less than forthcoming about these plans.

Other topics presented in this update are the proposed EPA rule for $\mathrm{NO}_{x}$ emissions reductions in Phase II Group 1 and Group 2 boilers, detailed descriptions of the shifts in coal supply, and an evaluation of the structure of the annual $\mathrm{SO}_{2}$ allowance auction.

Table 1. $\mathrm{SO}_{2}$ Emissions From Electric Utilities, 1985, 1990, 1994, and 1995 (Million Tons)

\begin{tabular}{|c|c|c|c|c|c|}
\hline & \multirow{2}{*}{$\begin{array}{c}1995 \\
\text { Capacity } \\
\text { (GW) }\end{array}$} & \multicolumn{4}{|c|}{ Total $\mathrm{SO}_{2}$ Emissions } \\
\hline & & 1985 & 1990 & 1994 & 1995 \\
\hline Phase I Units & $\begin{array}{c}130.9 \\
(28)\end{array}$ & $\begin{array}{l}10.5 \\
(67)\end{array}$ & $\begin{array}{c}9.7 \\
(62)\end{array}$ & $\begin{array}{l}8.0 \\
(56)\end{array}$ & $\begin{array}{l}5.3 \\
(45)\end{array}$ \\
\hline Non-Phase I Units & $\begin{array}{c}333.2^{\mathrm{a}} \\
(72)\end{array}$ & $\begin{array}{l}5.1 \\
(33)\end{array}$ & $\begin{array}{l}5.9 \\
(38)\end{array}$ & $\begin{array}{l}6.3 \\
(44)\end{array}$ & $\begin{array}{c}6.6 \\
(55)\end{array}$ \\
\hline Total ... & $\begin{array}{l}464.1 \\
(100)\end{array}$ & $\begin{array}{c}15.6 \\
(100)\end{array}$ & $\begin{array}{l}15.6 \\
(100)\end{array}$ & $\begin{array}{c}14.4 \\
(100)\end{array}$ & $\begin{array}{c}11.9 \\
(100)\end{array}$ \\
\hline
\end{tabular}

\footnotetext{
ancludes units that had $\mathrm{SO}_{2}$ emissions in 1995 only.
}

Note: $\mathrm{SO}_{2}$ emissions for 1985, 1990, and 1994 are estimated. Percentages are shown in parenthesis.

Sources: 1995: U.S. Environmental Protection Agency, "1995 Compliance Results, Acid Rain Program," EPA/430-R-96-012, July 1996. 1994 and prior years: Energy Information Administration, Form EIA-767, "Steam-Electric Plant Operation and Design Report." 


\section{Phase I Effects on Utilities}

According to the EPA, all of the Phase I plants, housing 445 Phase I boilers, were in compliance with Title IV at the end of 1995. The 445 Phase I boilers, associated with 435 generating units, had a total capacity of 130.9 gigawatts. This figure includes 261 Table 1 generating units, explicitly referred to in the text of Title $I V$, with a total capacity of 89.0 gigawatts and 174 substitution and compensating units (totaling 41.9 gigawatts of capacity) brought into Phase I under provisions of Title IV. A profile of the 435 Phase I generating units can be found in Table B1 of Appendix B.

\section{Compliance Options for Phase I}

Phase I affects the largest electric utility sources of $\mathrm{SO}_{2}$ emissions and the units that were brought into the program as substitution or compensating units. In Phase $\mathrm{I}$, affected units are required to have an allowance for each ton of $\mathrm{SO}_{2}$ they emit or they incur a penalty. Affected units are allocated emissions allowances based on the average annual British thermal units (Btu's) burned from 1985 through 1987 multiplied by 2.5 pounds of $\mathrm{SO}_{2}$ per million Btu. The initial quantity of allowances in most cases, is not sufficient to meet the amount of $\mathrm{SO}_{2}$ emitted in 1985 . Therefore, Phase I utilities must either reduce their emissions to the level of allowances allocated, or they can acquire additional allowances by purchasing them at an allowance auction or from another allowance owner.

The market-based approach for complying with environmental regulations established a firm annual limit on $\mathrm{SO}_{2}$ emissions from Phase I units (although with substitution and compensating unit provisions, this annual limit can vary from year to year during Phase I), but permitted allowance trading and a choice of compliance strategies. Utilities with relatively high costs of pollution control can purchase additional allowances from other utilities whose emissions reductions exceed the requirements of Title IV. Together they can meet their emissions requirements more efficiently than if each utility had to meet the $\mathrm{SO}_{2}$ limits separately. The allowance trading program gives utilities the flexibility to choose among a variety of methods to reduce $\mathrm{SO}_{2}$ emissions and reduce their pollution control costs at the same time.

A utility could choose one or a combination of the following methods to meet its annual emissions allowance limit:

- Fuel switching and/or blending with lower sulfur coal, cofiring, switching to another fuel

- Obtaining additional allowances

- Installing flue gas desulfurization equipment (scrubbers)

- Using previously implemented controls

- Retiring units

- Boiler repowering

- Substituting Phase II units

- Compensating with Phase II units.

\section{Compliance Methods Chosen}

On January 1, 1995, Phase I compliance methods effectively went into operation for the purpose of $\mathrm{SO}_{2}$ emissions monitoring by EPA. This section includes a discussion of the compliance methods chosen for the 261 Table 1 units and how the compliance methods relate to coal purchase price and specific plant implementation plans. The 174 substitution and compensating units are not included in the discussion.

\section{Fuel Switching and/or Blending}

Fifty-two percent (136 units) of the Table 1 units switched to or blended with a lower sulfur coal, accounting for 59 percent of the $\mathrm{SO}_{2}$ emissions reductions achieved in 1995 (Table 2). These choices were propelled mainly by the innovation of utilities in blending coals of varying sulfur contents to reduce the average $\mathrm{SO}_{2}$ emissions and by the availability of large quantities of lower sulfur coal on the market at favorable prices. This category includes some units in Kansas, Michigan, New Hampshire, New York, and Wisconsin that had already been switched to lower

4 "CAAA Phase I Performance: Overcompliance," Coal (October 1995), p.11. 


\begin{tabular}{|c|c|c|c|c|c|c|c|c|}
\hline Fuel Switching and/or Blending & 136 & 32 & 47,280 & $2,892,422$ & $4,768,480$ & $1,923,691$ & 53 & 59 \\
\hline \multicolumn{9}{|l|}{ Installing Flue Gas Desulfurization } \\
\hline Equipment (Scrubbers) ...... & 27 & 28 & 14,101 & 923,467 & $1,637,783$ & 278,284 & 16 & 28 \\
\hline Retired Facilities . . . . . . . . . & 7 & 32 & 1,342 & 56,781 & 121,040 & 0 & 2 & 2 \\
\hline Other $\ldots \ldots \ldots \ldots \ldots \ldots \ldots$ & 8 & 33 & 1,871 & 110,404 & 134,117 & 18,578 & 2 & 2 \\
\hline Total $\ldots \ldots \ldots \ldots \ldots \ldots \ldots$ & 261 & 32 & 88,989 & $5,550,821$ & $9,301,985$ & $4,444,432$ & 100 & 100 \\
\hline
\end{tabular}

${ }^{a}$ Base year of 1996 was used to calculate average age.

${ }^{b} \mathrm{One} \mathrm{SO}_{2}$ allowance permits one ton of $\mathrm{SO}_{2}$ emissions.

'Base year of 1985 was used to calculate $\mathrm{SO}_{2}$ emissions reductions.

$\mathrm{SO}_{2}=$ Sulfur dioxide.

Note: Fuel switching includes Phase 1 units switched to a lower sulfur coal in the 1990's. This category also includes units using state-mandated previously implemented controls that may have been switched prior to 1990. Other includes units that were repowered and those that switched to natural gas or petroleum. Totals may not equal sum of components because of independent rounding.

Sources: Compliance Method: The Utility Report December 1995, Energy Ventures Analysis, Inc. Age and Capacity: Energy Information Administration, Inventory of Power Plants 1994, DOE/EIA-0095(94) (Washington, DC, October 1995). 1985 Emissions: U.S. Environmental Protection Agency, National Allowance Data Base, Versions 2.11 (January 1993). 1995 Emissions: Acid Rain Division, U.S. Environmental Protection Agency.

sulfur coal to meet previously implemented controls mandated by State environmental regulations. ${ }^{5}$

It is useful to look at the individual characteristics of a few plants to understand the decisions made regarding switching. This section discusses the variations in the way three plants switched to lower sulfur coal: Ohio Edison's Sammis plant switched to coal from the Central Appalachian region, Associated Electric Cooperatives' Thomas Hill plant switched from Missouri coal in 1990 to lower sulfur coal from the Powder River Basin in 1994 and 1995, and the Coffeen plant of Central Illinois Public Service continued using coal from the Illinois Basin in 1995 as it had in 1990.

\section{The Sammis Plant}

The Sammis plant, operated and owned by Ohio Edison, has a coal-fired nameplate capacity of 2,303.5 megawatts with four 185.0 megawatt units, one 317.5 megawatt unit and two 623.0 megawatt units. Units 5, 6, and 7 are Table 1 units and they have a total capacity of 1,563.5 megawatts. In the early and mid-1980's, in response to EPA particulate control requirements and in anticipation of the Phase I compliance requirements, the Sammis plant replaced electrostatic precipitators (ESPs) in units 5, 6, and 7 to accommodate a wide variety of coals. The ESP, one means of removing fly ash from flue gas when fuels are burned in suspension, produces an electric charge on the ash particle to be collected and then attracts the charged particle by electronic forces to the collecting curtain. Fly ash can seriously interfere with the operation of a boiler unit, and, in some low-sulfur coals, can be resistant to being charged. Thus, in many cases, the flue gas must be treated with chemical conditioning agents, such as sulfur trioxide $\left(\mathrm{SO}_{3}\right)$ to reduce ash resistivity and to increase the collection efficiency of the ESP.

In 1985 Sammis received 24 percent of its coal from Ohio, 31 percent from Pennsylvania, about 32 percent from West Virginia and the rest from Kentucky. ${ }^{6}$ The average sulfur content of the total receipts was 1.67 percent by weight and the average delivered price was $\$ 46.76$ (1995 dollars) per short ton (191.4 cents per million Btu). In 1990, over 50 percent of Sammis' coal came from Ohio and Pennsylvania.

5 Energy Information Administration, Electric Utility Phase I Acid Rain Compliance Strategies for the Clean Air Act Amendments of 1990, DOE/EIA-0582 ( Washington, DC, March 1994), p 33.

6 Federal Energy Regulatory Commission (FERC) Form 423, "Monthly Report of Cost and Quality of Fuels for Electric Plants." 
However, in 1995, coal from Ohio and Pennsylvania was significantly reduced; less than one percent of Sammis' receipts came from Pennsylvania and none came from Ohio. Most of the coal came from southern West Virginia (56 percent) and eastern Kentucky ( 36 percent) by barge transportation, since Sammis has significant barge unloading capability. The average sulfur content went from 1.67 percent by weight in 1985 to 0.79 percent by weight in 1995 and the average delivered price of coal was reduced by 33 percent (1995 dollars) to $\$ 31.23$ per ton (128.1 cents per million Btu) in 1995.

Ohio Edison currently operates one lower sulfur coal pile for fueling all generators at the Sammis plant and recently has considered using different types of coal for the various units at the plant. However, that would entail the cost and burden of maintaining multiple coal piles. Ohio Edison estimates that maintaining a single coal pile could cost as much as $\$ 1$ million less than maintaining two separate piles.

\section{The Thomas Hill Plant}

The Thomas Hill plant located in Randolph County, Missouri, is one of two coal-fired plants owned by Associated Electric Coop., Inc. The Hill plant has a capacity of 1,135 megawatts, 465 megawatts of which are affected by Phase I at units 1 and 2. In 1985 and 1990 all coal receipts for the plant originated from Missouri-2,304,000 and 2,287,000 short tons, respectively. The average sulfur content for the coal in 1985 was 4.18 percent by weight and the delivered price was $\$ 46.42$ (1995 dollars) per short ton (223.4 cents per million Btu).

In 1992, the Thomas Hill plant received its first shipment of Powder River Basin coal-116,000 tons, 4 percent of its total coal purchases in 1992. In 1995, all coal receipts for the plant originated in Wyoming at an average delivered price of $\$ 12.55^{7}$ per short ton (71.8 cents per million Btu) with an average sulfur content of 0.20 percent by weight.

The introduction of Powder River basin coal at the Thomas Hill plant necessitated plant modifications to the coal handling and crushing systems and boiler modifications, including installation of new dampers and soot blowers. Western coal brittleness and dust-forming characteristics sometimes require dust suppression equipment to reduce the potential of explosions. ${ }^{8}$ Powder River basin coal is transported to the plant by rail in rotary car dumpers, which are rotated, tilted, and dumped by a specially designed track. In all, the coal-switching modifications totaled approximately $\$ 118$ million.

Coal receipts in 1995 at the Thomas Hill plant increased to $4,723,000$ tons in part because of the lower heat content $(8,744$ Btu's per pound as compared to a heat content of 10,382 Btu's per pound in 1985).

\section{The Coffeen Plant}

Central Illinois Public Service's Coffeen plant located in Montgomery County, Mlinois, has two Table 1 units, amounting to a capacity of 1,005.5 megawatts. In 1985, Coffeen received 1,970,000 short tons of coal from Macoupin County, Illinois, with an average sulfur content of 3.68 percent. In 1990, Coffeen received all of its coal from Macoupin County-1,746,000 short tons with 3.54 percent sulfur at $\$ 38.69$ (1995 dollars) per ton (182.7 cents per million Btu).

In response to Title $I V$, the Coffeen plant decided to continue using Illinois coal in 1995. This decision was facilitated by renegotiating a contract with the same supplier to provide lower sulfur coal and by modifying the plant with a new limestone addition system and a new electrode design for the ESP, costing approximately $\$ 1.3$ million and $\$ 500,000$, respectively.

Under a renegotiated contract, Coffeen received 1,690,000 short tons of coal from Macoupin County with a sulfur content of 0.91 percent by weight and average delivered price of $\$ 35.28$ per short ton (171.8 cents per million Btu) in 1995, which was 9 percent lower than the 1990 average delivered price.

Total capital costs to comply with the Title IV were approximately $\$ 2.2$ million with a one-time maintenance cost of approximately $\$ 1.5$ million. Operating costs have increased by approximately $\$ 300,000$ a year at the plant.

\section{Obtaining Additional Allowances}

An allowance authorizes the utility to emit 1 ton of $\mathrm{SO}_{2}$. Utilities designated the use of additional allowances as the primary compliance method for 32 percent of the Table 1 units ( 83 units). In addition to obtaining more allowances, these units reduced their emission levels by 9 percent in 1995 compared to 1985, as they decreased coal

7 This delivered price is an indication of the competitive price of Western coal. The dverage price of Wyoming coal delivered to all plants in the State of Missouri in 1995 was $\$ 15.36$ per short ton.

8 Energy Information Administration, Electric Utility Phase I Acid Rain Compliance Strategies for the CAAA90, DOE/EIA-0582 (Washington, DC, March 1994), p. 19. 
consumption by 2.5 million tons and lowered the sulfur content of coal consumed by 16 percent.

Emissions allowances are available from scrubbed plants and from plants switching to lower sulfur coal when these methods produce emissions reductions that exceed the targeted unit's reduction requirements. They are also available from the EPA's distribution of "bonus allowances" to non-Phase I utilities for using energy conservation strategies and to plants which opted to scrub earlier than required. ${ }^{9}$ These factors have contributed to an excess of allowances on the allowance market, few participants in allowance trading, and lower than projected market prices. Many attribute the low allowance prices primarily to the recent declines in coal prices. ${ }^{10}$ Therefore, utilities have been able to use allowances for the continued burning of higher sulfur coal from current sources or to purchase them at low prices, with plans to use the allowances to defer the higher cost of complying with Phase II.

Prices for $\mathrm{SO}_{2}$ emissions allowances have declined since their initial offering in the 1993 EPA allowance auction run by the Chicago Board of Trade and are well below the $\$ 1,500$ level that was estimated by various parties around the time of passage of CAAA90 $0^{11}$ (Figure 3).

The allowance market has shown a level of development far removed from the uncertainty associated with the first allowance auction. Sophisticated financial instruments typically associated with commodity markets are now characteristics of the allowance market. Some of these include forward contracts, options, and futures.

Originally, many economists expressed the following concerns with the manner in which EPA conducts the annual auctions each March:12

1) EPA, the largest seller in the auctions, has no minimum asking price.

2) Because winning bidders pay the amount they actually bid, a range of winning prices is generated.

3) The lowest-priced offers are matched to the highestpriced bids.
Figure 3. $1996 \mathrm{SO}_{2}$ Emission Allowance (Spot Market) Supply and Demand at the EPA Auction, March 1996

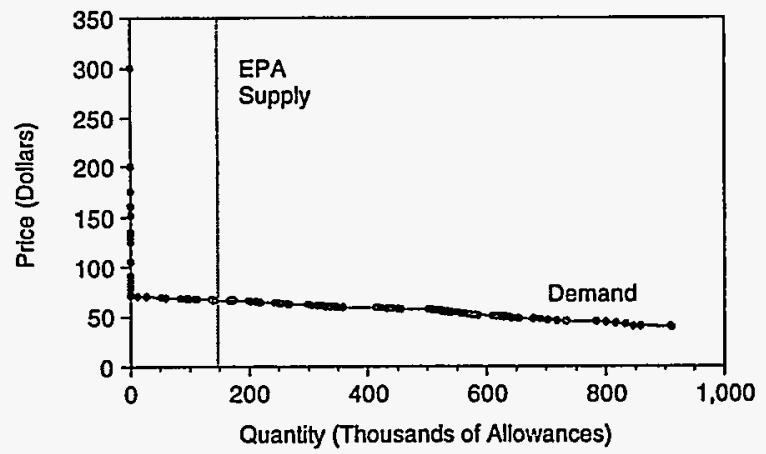

$\mathrm{SO}_{2}=$ Sulfur dioxide.

$E P A=$ U.S. Environmental Protection Agency.

Note: All bids to the left of the vertical EPA supply at quantity 150,000 were winning bids.)

Source: U.S. Environmental Protection Agency, Acid Rain Division, 1996 EPA SO${ }_{2}$ Allowance Auction Summary.

When EPA adopted the current auction design, it said it would monitor the auctions and identify any necessary changes to the design "that may be required to assure an orderly and competitive market." The General Accounting Office (GAO) has stated its belief that an auction with a single price is consistent with CAAA90 and the goals for the auction expressed in the legislative history. GAO goes on to say that "a single price auction could result in at least the same, if not higher, total proceeds to the extent that the incentive to submit lower bids present in the price-discriminating design would be removed."13

In response to the GAO report and general criticism that EPA received regarding the auction, EPA published an advanced notice of proposed rulemaking (ANPRM) in the Federal Register asking market participants whether a change in the auction design would be desired. ${ }^{14}$ The majority of commentors responded that changing the design at this time could disrupt the allowance market rather than better inform it, that a change to a single-price

9 “U.S. Utilities Opt Against Scrubbing," International Coal Report (October 30, 1995), p. 5.

${ }^{10}$ Juan-Pablo Montero, A. Denny Ellermen, and Richard Schmalensee, "The U.S. Allowance Trading Program for $\mathrm{SO}_{2}$ : An Update After the First Year of Compliance," Massachusetts Institute of Technology, for the Proceedings of the Second Workshop on Energy Externalities Organized by EC/OECD/IEA, Brussells, September 9-10, 1996, Draft: October 29, 1996, p. 13.

${ }^{11}$ Dallas Burtraw, Cost Savings Sans Allowance Trades? Evaluating the $\mathrm{SO}_{2}$ Emission Trading Program to Date, Resources for the Future, (Washington, DC, February 1996), p. 9.

${ }_{12}$ Communication from Joe Kruger of the Environmental Protection Agency, December 6, 1996.

13 United States General Accounting Office, Report to the Chairman, Environment, Energy and Natural Resources, Subcommittee, Committee on Government Operations, House of Representatives, Air Pollution: Allowance Trading Offers and Opportunity to Reduce Emissions at Less Cost, GAO/RCED-95-40, (Washington, DC, December 1994), p. 53.

${ }_{14}$ Federal Register, Vol. 61, No. 110 (June 6, 1996), pp. 28761-28763. 
auction design would probably have been more relevant in 1993 and 1994, when price discovery was very limited, and the EPA auctions played a large role in establishing market price. Now that other year-round price discovery mechanisms exist and a market price for allowances has become clearly established, the auctions are no longer setting market prices, they are reflecting them. According to the EPA, the consensus appears to be that the current auction design is neither leading nor misinforming the market and should not be changed and therefore EPA has no plans to change the auction format. ${ }^{15}$

One can see that there has been much activity in the allowance market. For example, the differences between Potomac Electric Power Company's (PEPCO's) 1995 allowance allocations and those deducted for emissions does not equal the number of allowances that PEPCO is carrying over to 1996 (Table 3). EPA has acknowledged that there has been more trading than is reflected in the Allowance Tracking System.

Because of the low allowance prices relative to other compliance options, particularly scrubbers, allowances are seen as an attractive compliance option in some cases. Illinois Power's (IP) Baldwin plant did not significantly reduce its emissions in 1995 because IP decided that acquiring the additional allowances needed for its $\mathrm{SO}_{2}$ emissions was economically viable. As prices climb, other actions will become more attractive, but for now, holding allowances is seen by some as a reasonable approach for meeting Phase I compliance requirements and by most as a way to hedge against uncertainty for Phase II.

\section{Installing Scrubbers}

Units with scrubbers installed for Phase I compliance accounted for 28 percent of $1995 \mathrm{SO}_{2}$ emissions reductions, the second largest share after fuel-switching units (59 percent). Sixteen utilities installed scrubbers at 27 units (Table 4), 10 percent of the Table 1 units. Fewer utilities than expected opted to scrub high-sulfur coal supplies, with some utilities located in higher sulfur coalfields indicating they will postpone scrubber installations several years beyond $2000 .^{16}$ The availability of emissions allowances and the failure of State legislators in Illinois and Indiana to enact laws that would protect local higher sulfur coal supplies are factors contributing to the utilities' decisions to delay or avoid scrubbing.

All scrubber systems rely on a chemical reaction with a sorbent to remove $\mathrm{SO}_{2}$ from flue gases. Scrubber systems are either "wet" or "dry." In the more common wet scrubber process, flue gases containing $\mathrm{SO}_{2}$ are contacted with a sorbent liquid that results in the formation of a wet solid byproduct. The liquid sorbent is sprayed into the flue gas in an absorber vessel. Most wet scrubber systems use alkaline slurries of limestone or slaked lime as sorbents. Sulfur oxides react with the sorbent to form calcium sulfite and calcium sulfate, which is a wet

Table 3. PEPCO's 1995 Allowance Totals

\begin{tabular}{|c|c|c|c|c|}
\hline Unit & $\begin{array}{c}1995 \\
\text { Allowance } \\
\text { Allocation } \\
\end{array}$ & $\begin{array}{c}1995 \text { Allowances } \\
\text { Deducted for } \\
\text { Emissions }\end{array}$ & Difference & $\begin{array}{c}\text { Allowances } \\
\text { Carried Over } \\
\text { to } 1996 \\
\end{array}$ \\
\hline Chalk Point ST1 ............. & 25,403 & 20,543 & 4,860 & 3,700 \\
\hline Chalk Point ST2 ............. & 23,690 & 20,544 & 3,146 & 6,756 \\
\hline Morgantown ST1 ............ & 39,864 & 28,040 & 11,824 & 7,257 \\
\hline Morgantown ST2 $\ldots \ldots \ldots \ldots$ & 45,592 & 38,515 & 7,077 & 10,017 \\
\hline Conemaugh $1, \ldots \ldots \ldots \ldots$ & 9,389 & 460 & 8,929 & 106 \\
\hline Conemaugh $2 \ldots \ldots \ldots \ldots$ & 8,335 & 7,131 & 1,204 & 1,859 \\
\hline Chalk Point $3 . \ldots \ldots \ldots \ldots$. & 9,000 & 3,010 & 5,990 & 5,990 \\
\hline Chalk Point $4 \ldots \ldots \ldots \ldots \ldots$ & 1,519 & 1,354 & 165 & 373 \\
\hline PEPCO Total... & 162,792 & 119,597 & 43,195 & 36,057 \\
\hline
\end{tabular}

Note: One allowance permits the emission of 1 ton of sulfur dioxide.

Source: Environmental Protection Agency, Acid Rain Division, 1995 Compliance Results, EPA/430-R-96-012, July 1996, p. D-6.

${ }^{15}$ Communication from Joe Kruger of the Environmental Protection Agency, December 6, 1996.

16 "U.S. Utilities Opt Against Scrubbing," International Coal Report, October 30, 1995, p 5. 
Table 4. Scrubber Retrofits for Compliance With Phase I

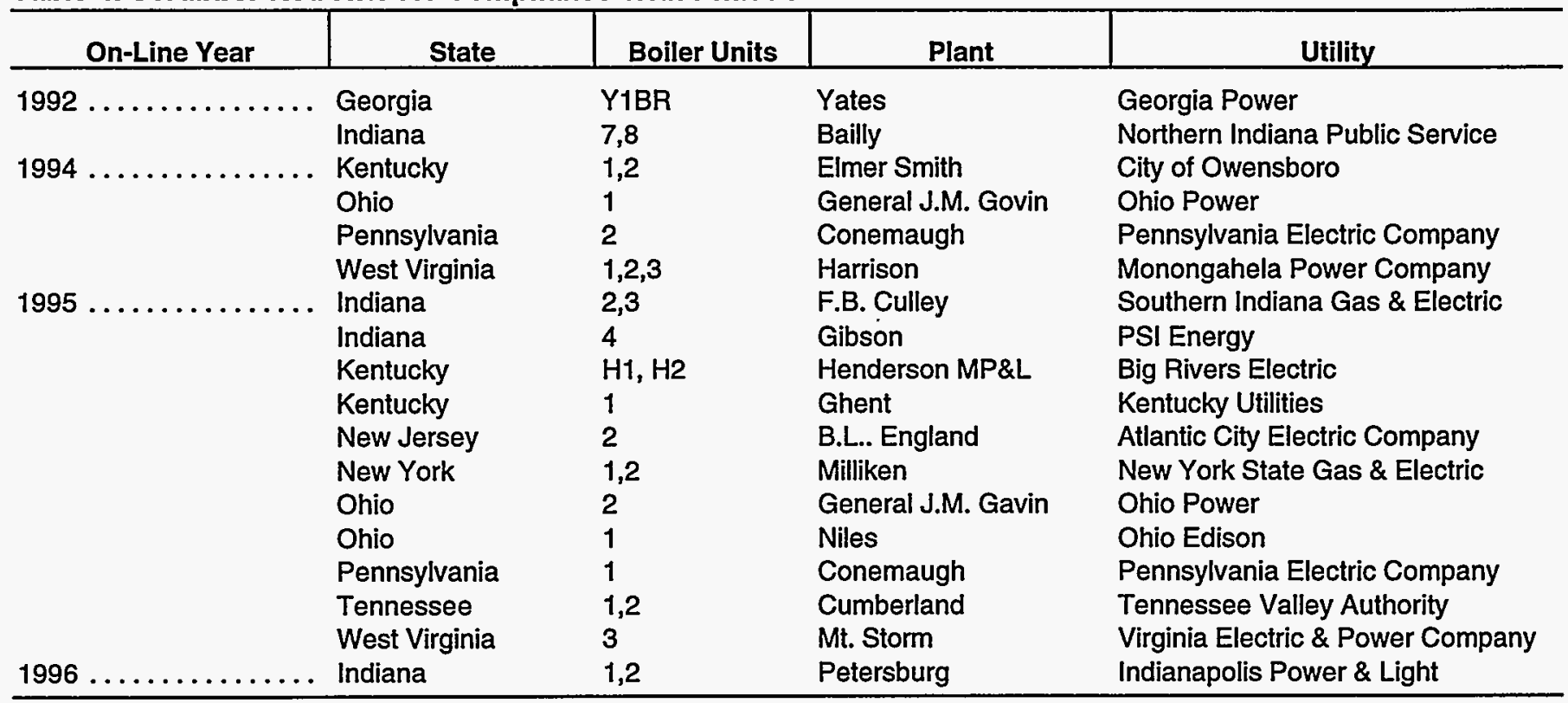

Source: U.S. Environmental Protection Agency, Applications for Acid Rain Program Phase I Bonus and Extension $\mathrm{SO}_{2}$ Emission Allowances (March 31, 1993).

byproduct. Oxidation of this results in a gypsum byproduct that can be sold.

Dry scrubber systems can be grouped into three categories: spray dryers, circulating spray dryers, and dry injection systems. All three categories avoid total water saturation of the flue gas, and provide a dry, free-flowing waste product. The elimination of any liquid waste is the ma jor difference between dry scrubbers and wet scrubbers.

Scrubbers have been used for some time and are the standard by which new technology is judged. The last decade has seen improvement in process chemistry, simplified designs, and other technological enhancements. All these improvements have improved reliability, efficiency, cost, waste prevention, and reduced energy consumption of scrubbers. The wet limestone system has been the most popular scrubber choice for Phase I largeunit retrofits. The Phase II decisions on scrubbers are essentially on hold because of utility competition, the desire to avoid large capital expenditures, and low $\mathrm{SO}_{2}$ allowance prices.

Before 1980, scrubber systems were unreliable. Scrubber components often suffered from plugging and scaling, and material failures were frequently responsible for unplanned outages. The availability of these early systems was as low as 85 percent. By simplifying process configurations, selecting better materials, and using redundant equipment in critical areas, much higher availability has now been attained. More recently, the North American Electric Reliability Council concluded that wet scrubber systems contributed, on average, to system availability of 99.7 percent. $^{17}$

Operating data prove that wet scrubbers can reliably remove 95 percent or more of the $\mathrm{SO}_{2}$ from stack emissions. In fact, $\mathrm{SO}_{2}$ removal efficiencies often are as high as 98 percent or 99 percent. Many scrubbers currently retrofitted to comply with CAAA90 will remove more $\mathrm{SO}_{2}$ than required, thus generating marketable emissions allowances. The use of recently developed additives, such as dibasic acid, formic acid, and magnesium compounds, improve efficiencies, especially for high-sulfur coal. Dry scrubbers also are quite efficient. Spray dryers often achieve greater than 90 percent $\mathrm{SO}_{2}$ removal on coals 1 percent to 2 percent sulfur. ${ }^{18}$

Recent technological advances in wet scrubber systems have reduced capital and operating costs relative to

\footnotetext{
17 "Scrubber myths and realities; don't let common misperceptions about flue gas desulfurization systems bias a realistic appraisal of this capable control technology," Power Engineering (January 1995), p. 35.

${ }^{18}$ Ibid.
} 
historical values. Capital costs have been reduced by more than 30 percent. ${ }^{19}$ These innovations include installing larger (and fewer) absorber modules, eliminating flue gas reheat components, incorporating additives into the process design, fitting higher velocity absorbers and alternative duct work designs, installing absorbers in the base of a new chimney, and reducing reagent preparation costs.

The retrofit costs of scrubbers are site-specific and vary considerably. Site-specific factors, such as space and access limitations, major modifications to existing equipment, and the operating condition of the units, all affect retrofit costs. The average costs of Phase I retrofits ranged from $\$ 123$ per kilowatt to $\$ 317$ per kilowatt for different units. Average operating and maintenance costs for scrubbers, exclusive of capital recovery, are 1.42 mills per kilowatt hour. This increase in electrical rates is about onehalf that associated with pre-1990 wet scrubbers. If commercial grade gypsum, a byproduct of scrubbing, is produced and sold, it would produce revenue and reduce disposal costs. ${ }^{20}$

Advances in design and technology have greatly improved scrubber's energy efficiency. The current generation of wet scrubbers that incorporate advances in chimney design, construction materials, regenerative heaters, and additives to enhance pollutant removal efficiencies consumes less than 1 percent of total plant energy. Dry scrubbers consume even less. Some new scrubber designs even employ heat exchangers, which use waste heat from stack gases and actually increase power plant efficiency. Scrubbers with condensing heat exchangers can recover as much as 4 percent of additional energy, thus offsetting the scrubbers use of plant energy. ${ }^{21}$

\section{Retiring Facilities}

Electric utilities have retired seven Table I units, most of which are outdated and small capacity units. Retired units accounted for 2 percent of $1995 \mathrm{SO}_{2}$ emissions reductions. Wisconsin Electric Power Company removed four units from service at North Oak Creek in 1988 and 1989. Indiana-Michigan Power's Breed plant, shut down in March 1994, is undergoing asbestos removal and may be used again in the future. Cleveland Electric Illumi- nating's Avon Lake unit 8 was retired in November 1987 and Iowa Power's Des Moines unit 7 is out of service but can be brought back into service in 180 days.

\section{Other}

Units in this category accounted for 2 percent of $1995 \mathrm{SO}_{2}$ emissions reductions. One Table I unit, PSI Energy Inc.'s Wabash River Station unit 1, has been repowered with an integrated gasification combined-cycle generator. Using new technology, the plant burns high-sulfur coal, reduces $\mathrm{SO}_{2}$ emissions, and increases the plant capacity by approximately 155 megawatts. One unit each at Ilinois Power's Vermilion plant and Ohio Edison's Edgewater plant were switched to natural gas. Two units at the Long Island Lighting Company's Port Jefferson plant and three units at North Port plant are using No. 6 fuel oil.

\section{Electric Utility Compliance Strategies, Costs, and Emissions}

Electric utilities in the United States have invested heavily in air pollution control equipment during the last decade. Scrubbers were installed at some utilities to reduce $\mathrm{SO}_{2}$ emissions, and many utilities have retrofitted low- $\mathrm{NO}_{x}$ burners to reduce $\mathrm{NO}_{\mathrm{x}}$ emissions. Some utilities have installed equipment to accommodate cleaner fuel and to monitor emissions levels. Cumulatively through 1986, major investor-owned utilities had invested $\$ 16.7$ billion in air pollution control facilities (Figure 4). By 1990, investments had increased to $\$ 20.8$ billion, and by the end of 1995 utilities had invested $\$ 29.6$ billion. ${ }^{22}$

The level of investment in air pollution control equipment varies according to the location and size of the plant and the fuel mix used at the plant. Utilities owning units affected under Phase I had cumulative investments of $\$ 14.4$ billion in 1995, almost half of the total utility investments in air pollution control facilities. ${ }^{23}$ Power plants in the East Central and Mid-Atlantic regions (corresponding to the East Central Area Reliability Coordination Agreement (ECAR) and the Mid-Atlantic Area Council (MAAC) of the North American Reliability Council (NERC)) account for most of these investments

\footnotetext{
19 Ibid.

20 Ibid.

21 Ibid.

22 Energy Information Administration, Financial Statistics of Major U.S. Investor-Owned Electric Utilities, DOE/EIA-0437(95/1) (Washington, DC, December 1996 and previous years).

${ }^{23}$ These investments were for all air pollution control requirements, not just to meet the provisions of the acid rain program.
} 
Figure 4. Cumulative Investment in Air Pollution Control Facilities by Major InvestorOwned Utilities, 1986-1995

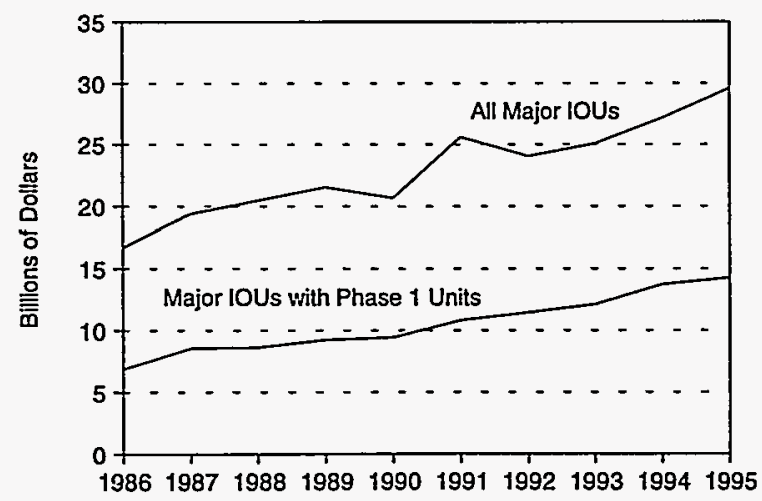

IOU = Investor-Owned Utilities.

Note: Air pollution control facilities include (1) scrubbers, electrostatic precipitators, tall smokestacks, etc.; (2) changes necessary to accommodate use of environmentally clean fuels such as low-ash or low-sulfur fuel including storage and handling equipment; (3) monitoring equipment; and (4) other equipment.

Source: Energy Information Administration, Financial Statistics of Major U.S. Investor-Owned Electric Utilities, DOE/EIA-0437 (95/1) (Washington, DC, December 1996 and previous years).

(Figure 5). These regions have a high concentration of large coal-fired units, many of which are affected by Phase I.

\section{Compliance Costs for Title IV}

Previous studies have indicated that compliance costs for Title IV would be lower with the introduction of an allowance trading system. In 1992 for example, EPA estimated that the cost of compliance would be up to 50 percent lower using emission allowance trading compared to command and control regulation. The U.S. General Accounting Office (GAO) supported that statement. GAO estimated that by the year $2002, \mathrm{SO}_{2}$ reductions under traditional regulation would cost as much as $\$ 4.5$ billion annually, but an $\mathrm{SO}_{2}$ allowance trading program would reduce the costs by $\$ 2$ to $\$ 3$ billion annually. ${ }^{24}$

\section{Figure 5. Total Investments in Air Pollution Control Facilities by Major Investor- Owned Utilities, by NERC Region, 1995}

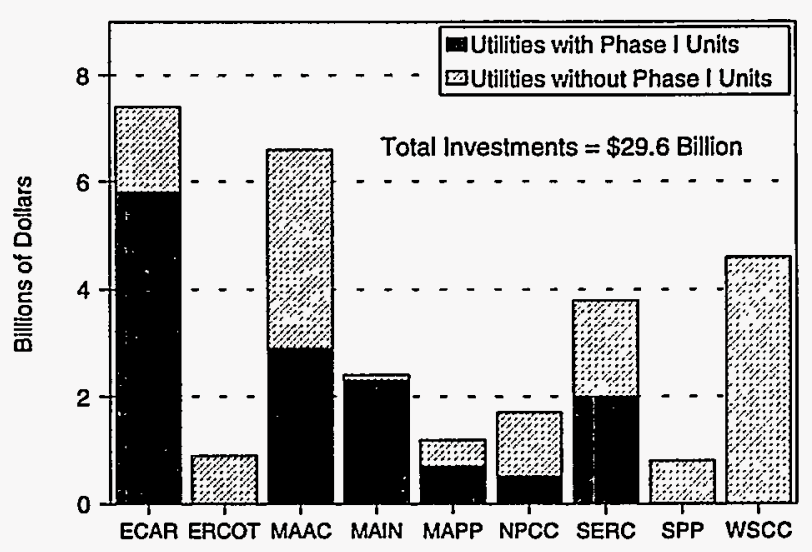

$\mathrm{IOU}=$ Investor-Owned Utilities.

Note: Air pollution control facilities include (1) scrubbers, electrostatic precipitators, tall smokestacks, etc.; (2) Changes necessary to accommodate use of environmentally clean fuels such as low-ash or low-sulfur fuel including storage and handling equipment; (3) monitoring equipment; and (4) other equipment.

$E C A R=$ East Central Area Reliability Coordination Agreement.

ERCOT $=$ Electric Reliability Council of Texas.

MAAC = Mid-Atlantic Area Council.

MAIN = Mid-America Interconnected Network.

MAPP $=$ Mid-Continent Area Power Pool.

NPCC $=$ Northeast Power Coordinating Council.

SERC = Southeastern Electric Reliability Council.

SPP $=$ Southwest Power Pool

WSCC $=$ Western Systems Coordinating Council.

Source: Energy Information Administration, Financial Statistics of Major U.S. Investor-Owned Electric Utilities, DOE/EIA-0437(95/1) (Washington, DC, December 1996).

The Massachusetts Institute of Technology (MIT), in a preliminary report, estimated an annualized compliance cost of $\$ 836$ million (Table 5). ${ }^{25}$ This estimate, which was based on program data through 1995, represents less than 0.6 percent of the $\$ 151^{26}$ billion of electric operating expenses of investor-owned utilities in 1995.

${ }^{24}$ General Accounting Office, Air Pollution Alllowance Trading Offers an Opportunity to Reduce Emissions at Less Cost, GAO/RC ED-95-30 (Washington, DC, December 1994), p. 37.

${ }_{25}$ Massachusetts Institute of Technology, for the Proceedings of the Second Workshop on Energy Externalities, Brussels, September 9-10, 1996, The U.S. Allowance Trading Program for Sulfur Dioxide: An Update After the First Year of Compliance, Draft (Cambridge, MA, October 29, 1996).

${ }^{26}$ Energy Information Administration, Financial Statistics of Major U.S. Investor-Owned Electric Utilities 1995, DOE/EIA-0437(95)/1 (Washington, DC, December 1996). 
Table 5. Annualized $\mathrm{SO}_{2}$ Compllance Cost for CAAA90 Title IV (1995 Dollars) $^{\mathrm{a}}$

\begin{tabular}{|c|c|c|c|}
\hline $\begin{array}{c}\text { Method of } \\
\text { Compliance for Title IV }\end{array}$ & $\begin{array}{l}1995 \text { Emissions } \\
\text { Reduction } \\
\text { (thousand } \\
\left.\text { tons of } \mathrm{SO}_{2}\right)^{b}\end{array}$ & $\begin{array}{l}\text { Annualized } \\
\text { Compliance Cost } \\
\text { (thousand dollars) }^{c}\end{array}$ & $\begin{array}{c}\text { Annualized } \\
\text { Average Cost per } \\
\text { Ton of } \mathrm{SO}_{2} \text { Removed }\end{array}$ \\
\hline \multicolumn{4}{|l|}{ Scrubbing } \\
\hline Title IV Scrubbers $\ldots \ldots \ldots \ldots \ldots \ldots \ldots$ & 1,734 & 558,128 & 322 \\
\hline NSPS Scrubbers $^{d} \ldots \ldots \ldots \ldots \ldots \ldots$ & 21 & 1,345 & 64 \\
\hline \multicolumn{4}{|l|}{ Switching } \\
\hline Bituminous ${ }^{\ominus}$ & 1,547 & 258,737 & 167 \\
\hline Subbituminous (Powder River Basin (PRB)) . & 160 & 18,126 & 113 \\
\hline Subtotal...$\ldots \ldots \ldots \ldots \ldots \ldots \ldots \ldots \ldots$ & 3,462 & 836,336 & 242 \\
\hline \multicolumn{4}{|l|}{ No Cost Switching ${ }^{f}$} \\
\hline PRB \& CO/UT $\ldots \ldots \ldots \ldots \ldots \ldots \ldots$ & 369 & & \\
\hline Natural Gas $\ldots \ldots \ldots \ldots \ldots \ldots \ldots \ldots$. & 20 & & \\
\hline Midwest $\ldots \ldots \ldots \ldots \ldots \ldots \ldots \ldots \ldots \ldots$ & 32 & & \\
\hline Others $\ldots \ldots \ldots \ldots \ldots \ldots \ldots \ldots \ldots \ldots \ldots \ldots \ldots \ldots$ & 5 & & \\
\hline Subtotal $\ldots . \ldots \ldots \ldots \ldots \ldots \ldots \ldots \ldots \ldots$ & 426 & & \\
\hline Total $\ldots \ldots \ldots \ldots \ldots \ldots \ldots \ldots \ldots \ldots \ldots$ & 3,888 & 836,336 & 215 \\
\hline
\end{tabular}

QPreliminary annualized compliance cost for $\mathrm{SO}_{2}$ could be changed as MIT finalizes their estimates. Costs are not included for low $\mathrm{NO}_{x}$ control and continuous emissions monitoring systems.

b The baseline year to compare $1995 \mathrm{SO}_{2}$ emissions is 1993. It is assumed that the reductions before 1993 are not due to the CAAA90, but to economic reasons. The $1995 \mathrm{SO}_{2}$ emissions reductions are the difference between the $\mathrm{SO}_{2}$ emissions that would have been observed in 1995 in the absence of Title IV and the actual emissions. The $\mathrm{SO}_{2}$ emissions that would have been observed in 1995 was calculated as the product of the emissions rates in 1993 and the heat input in 1995.

"A capital charge of 14 percent is used to annualize initial fixed investments in scrubbers or switching to lower sulfur coal. The 14 percent includes 9 percent of capital cost and 5 percent of 20 years' linear depreciation.

"The New Source Performance Standards (NSPS) scrubbers were installed before Title IV was passed. Only variable costs of extra reductions are included for these scrubbers, not any fixed cost.

${ }^{6}$ Bituminous switching from high-sulfur to low-sulfur coal includes premiums paid for low-sulfur bituminous coal.

'The "No Cost Switching" for $\mathrm{SO}_{2}$ reductions would have taken place regardless of Title IV. Most of these are switches to low-sulfur subbituminous western coal (Powder River Basin and Colorado and Utah) due to the reduction in coal prices, especially the decline in rail rates.

Sources: Massachusetts Institute of Technology, Center for Energy and Environmental Policy Research, $\mathrm{SO}_{2}$ Compliance Costs with Titte IV, Memorandum (from Juan-Pablo Montero on December 24, 1996) to Art Fuldner and Ron Hankey, Office of Coal, Nuclear, Electric and Alternate Fuels, Energy Information Administration. Massachusetts Institute of Technology, Center for Energy and Environmental Policy Research, More on $\mathrm{SO}_{2}$ Compliance Costs with Title IV, Memorandum (from Juan-Pablo Montero on January $13,1997)$ to Art Fuldner, Office of Coal, Nuclear, Electric and Alternate Fuels, Energy Information Administration.

The lowest annualized average cost through 1995 for Phase I is switching of bituminous plants to burn lower sulfur subbituminous coal, with modifications, from the Powder River basin (PRB) ( $\$ 113$ per ton of $\mathrm{SO}_{2}$ removed). The most expensive is retrofitting scrubbers at $\$ 322$ per ton of $\mathrm{SO}_{2}$ removed. Utilities removed more $\mathrm{SO}_{2}$ by switching higher sulfur bituminous coal to lower sulfur bituminous coal (1,547 thousand tons) com- pared to switching from higher sulfur bituminous coal to lower sulfur subbituminous coal (160 thousand tons). Also, utilities switching to subbituminous coal from PRB and Colorado/Utah with no modification cost achieved a large $\mathrm{SO}_{2}$ reduction (369 thousand tons) compared to switching with modifications from bituminous to subbituminous coal. 


\section{Specific Utility Compliance Plans and Costs}

This section of the report presents a detailed look at Phase I compliance strategies and compliance costs through 1995 for six utilities, ${ }^{27}$ updating an earlier report on Phase I compliance strategies for these utilities. ${ }^{28}$ These utilities were selected to obtain a representative sample of generating capacities, sulfur dioxide $\left(\mathrm{SO}_{2}\right)$ emissions, locations, and initial compliance strategies. Also, the willingness to participate and share information was essential. Tables 6 through 8 and Figure 6 contain utility level data referred to throughout the discussion. Appendix $C$ lists detailed information on the characteristics and costs of compliance for each of the six utilities' plants affected by Phase I. Because the data for these utilities cover only 1 year of a multi-year program, compliance strategies, annual compliance costs, and even total capital costs for Phase I will likely change for some units. One such cost that will most certainly change is emissions allowances. Different substitution or compensating units might also be selected for participation in future years. The point is, because utilities are constantly looking for ways to achieve minimum compliance costs, changes in compliance strategies and costs are expected over the life of the acid rain program.

\section{Illinois Power}

Illinois Power (IP) operates eight power plants with an electric-generating capacity of 5.0 gigawatts. Initially, 45 percent of IP's generating capacity (five units) was affected by Phase I. Under the substitution revisions of CAAA90, IP added 8 relatively small units to its Phase I-affected units, increasing its affected capacity to 54 percent of total generating capacity..$^{29}$ Phase I affects the generating capacity at Baldwin, Hennepin, Vermillion, Havana, and Wood River power plants.

IP originally planned to install scrubbers to meet the $\mathrm{SO}_{2}$ emissions standards at the 1.9 gigawatts Baldwin Plant

Table 6. Characteristics of Selected Phase I Utilities

\begin{tabular}{|c|c|c|c|c|c|c|c|}
\hline \multirow[b]{2}{*}{ Utility $^{\mathbf{a}}$} & \multirow[b]{2}{*}{$\begin{array}{c}\text { Affected } \\
\text { Nameplate } \\
\text { Capacity } \\
\text { (Utility } \\
\text { Owned) } \\
\text { (MW) }\end{array}$} & \multirow[b]{2}{*}{$\begin{array}{c}\text { Total } \\
\text { Capacity } \\
(\mathrm{MW}) \\
\end{array}$} & \multirow[b]{2}{*}{$\begin{array}{l}\text { Percent } \\
\text { Capacity } \\
\text { Affected }\end{array}$} & \multicolumn{4}{|c|}{ Sulfur Dioxide Emissions Allowances } \\
\hline & & & & $\begin{array}{c}1995 \\
\text { Allocation } \\
\text { of } \mathrm{SO}_{2} \\
\text { Allowances }\end{array}$ & $\begin{array}{c}\text { Allowances } \\
\text { Deducted } \\
\text { for } 1995 \\
\mathrm{SO}_{2} \\
\text { Emissions }\end{array}$ & $\begin{array}{l}\text { Differences } \\
\text { Between } \\
\text { Allowances } \\
\text { and } 1995 \\
\text { Emissions }\end{array}$ & $\begin{array}{c}\text { Allowances }^{b} \\
\text { Carried } \\
\text { Over } \\
\text { to } 1996 \\
\end{array}$ \\
\hline Illinois Power . . . . . . . . . & 2,699 & 5,005 & 53.9 & 186,579 & 297,504 & $(110,925)^{c}$ & 645 \\
\hline Pennsylvania P\&L & 2,343 & 8,704 & 26.9 & 185,700 & 136,411 & 49,289 & 47,749 \\
\hline Potomac Electric Power & 3,480 & 6,433 & 54.1 & 162,792 & 119,597 & 43,195 & 36,057 \\
\hline Cincinnati G\&E $\ldots \ldots \ldots$ & 2,664 & 5,300 & 50.3 & 155,384 & 107,734 & 47,650 & 55,716 \\
\hline Georgia Power . . . . . . . . . & 10,252 & 15,995 & 64.1 & 715,187 & 372,586 & 342,601 & 211,835 \\
\hline Southern Indiana G\&E ... & 530 & 1,359 & 39.0 & 38,095 & 21,390 & 16,705 & 5,392 \\
\hline
\end{tabular}

'The full utility names are Illinois Power Company, Pennsyivania Power \& Light Company, Potomac Electric Power Company, Cincinnati Gas \& Electric Company, Georgia Power Company, and Southern Indiana Gas \& Electric Company.

${ }^{b}$ Allowances carried over to 1996 may not equal the differences between allocated and 1995 emissions due to purchases or sales of additional allowances. The data in this table do not account for a utility's purchases and sales of allowances.

'Illinois Power purchased enough emissions allowances to cover their 1995 emissions.

$\mathrm{SO}_{2}=$ Sulfur dioxide.

$\mathrm{MW}=$ Megawatt.

Note: For unit level data, see Appendix C.

Source: Environmental Protection Agency, "1995 Compliance Results Acid Rain Program," EPA/430-R-96-012 (Washington, DC, July 1996).

\footnotetext{
${ }^{27}$ Sources of information on these utilities consisted of personal contact with each utility; the Securities and Exchange Commission's, "1995 10K"; the Federal Energy Regulatory Commission's, "Interrogatory on Fuel and Energy Purchases Practices, 1992-1993"; FERC Form 580; and various articles published in trade journals.

${ }^{28}$ Energy Information Administration, Electric Utility Phase I Acid Rain Compliance Strategies for the Clean Air Act Amendments of 1990, DOE/EIA-0582 (Washington, DC, March, 1994).

${ }^{29}$ IP also substituted five PacifiCorp units located in Wyoming and Utah. These units are not included in the total.
} 
Table 7. Costs of Phase I Compliance for Selected Utilities

\begin{tabular}{|c|c|c|c|c|c|c|c|c|c|c|c|}
\hline \multirow[b]{3}{*}{ Utility $^{\mathrm{a}}$} & \multirow{3}{*}{$\begin{array}{c}\text { Number of } \\
\text { Low-NO } \\
\text { Burners }\end{array}$} & \multirow{3}{*}{$\begin{array}{c}\text { Number } \\
\text { of } \\
\text { CEMS }\end{array}$} & \multirow{3}{*}{$\begin{array}{c}\begin{array}{c}\text { Number } \\
\text { of } \\
\text { Scrubbers }\end{array} \\
\end{array}$} & \multicolumn{2}{|c|}{$\mathrm{SO}_{2}$ Control } & \multirow{2}{*}{$\begin{array}{c}\begin{array}{c}\mathrm{NO}_{\mathrm{x}} \\
\text { Control }\end{array} \\
\text { Capital } \\
\text { Cost }\end{array}$} & \multicolumn{2}{|c|}{ CEMS } & \multirow[b]{2}{*}{$\begin{array}{l}\text { Total } \\
\text { Capital } \\
\text { Costs } \\
\end{array}$} & \multirow{3}{*}{$\begin{array}{c}\text { Total } \\
\text { Annual } \\
\text { O\&M } \\
\text { Costs } \\
\end{array}$} & \multirow{3}{*}{$\begin{array}{l}\text { Average } \\
\text { Capital } \\
\text { Cost } \\
\text { (dollars/ kW } \\
\text { affected) } \\
\end{array}$} \\
\hline & & & & $\begin{array}{c}\text { Capital } \\
\text { Cost }\end{array}$ & $\begin{array}{l}\text { Annual } \\
\text { O\&M } \\
\text { Cost }\end{array}$ & & $\begin{array}{c}\text { Capital } \\
\text { Cost }\end{array}$ & $\begin{array}{l}\text { Annual } \\
\text { O\&M } \\
\text { Cost }\end{array}$ & & & \\
\hline & & & & \multicolumn{5}{|c|}{ (million dollars) } & & & \\
\hline Illinois Power...... & 2.0 & 13.0 & 0.0 & 34.6 & 18.5 & 12.7 & 15.2 & 0.9 & 62.5 & 19.4 & 23.15 \\
\hline Pennsylvania P\&L .... & 7.2 & 5.2 & 0.2 & 51.2 & 2.2 & 70.7 & 11.1 & c & 133.0 & 2.2 & 56.76 \\
\hline Potomac Electric Power & 6.0 & 6.5 & 0.2 & 62.4 & 1.8 & 120.6 & 12.8 & c & 195.8 & 1.8 & 56.27 \\
\hline Cincinnati G\&E & 1.4 & 5.7 & 1.0 & 12.4 & $c^{d}$ & 6.9 & 3.5 & c & 22.8 & c & 16.39 \\
\hline Georgia Power ....... & 15.1 & 19.4 & 1.0 & 47.0 & 2.0 & 125.3 & 17.1 & c & 189.5 & 2.0 & 18.48 \\
\hline Southern Indiana G\&E & 2.0 & 2.5 & 1.0 & 103.0 & 4.0 & 5.0 & 2.8 & 0.2 & 110.8 & 4.2 & 208.90 \\
\hline
\end{tabular}

aThe full utility names are Illinois Power Company, Pennsylvania Power \& Light Company, Potomac Electric Power Company, Cincinnati Gas \& Electric Company, Georgia Power Company, and Southern Indiana Gas \& Electric Company.

b fractional value indicates that ownership of equipment was allocated across more than one unit.

${ }^{\circ}$ Costs not estimated.

aThe capital costs for the scrubber were not included because the scrubber was installed in 1980, before passage of the Clean Air Act Amendments of 1990.

${ }^{-}$Some of these costs are offset by selling the gypsum produced by the scrubber.

$\mathrm{NO}_{\mathrm{x}}=$ Nitrogen oxides.

$\mathrm{SO}_{2}=$ Sulfur dioxide.

$\mathrm{KW}=$ Kilowatt.

CEMS $=$ Continuous emissions monitor system

$\mathrm{O} \& M=$ Operation and maintenance.

Notes: In some cases the costs are low because cost estimates were not available for all of the Phase I units. For unit level data, see Appendix $C$.

Sources: Personal contact with Illinois Power, Pennsylvania Power and Light, Potomac Electric Power, Cincinnati Gas and Electric, Georgia Power, and Southern Indiana Gas \& Electric. 
Table 8. Costs and Quality of Fuels for Selected Electric Utility Phase I Plants, 1985, 1990, and 1995 (Delivered Costs are in 1995 Dollars)

\begin{tabular}{|c|c|c|c|c|c|c|c|c|c|}
\hline \multirow[b]{2}{*}{ Utllity/Plant } & \multicolumn{3}{|c|}{1985} & \multicolumn{3}{|c|}{1990} & \multicolumn{3}{|c|}{1995} \\
\hline & $\begin{array}{c}\text { Quantity } \\
\text { (thousand } \\
\text { short tons) }\end{array}$ & $\begin{array}{c}\text { Sulfur } \\
\text { Content } \\
\text { (percent) }\end{array}$ & $\begin{array}{c}\text { Dellvered } \\
\text { Cost } \\
\text { (dollars/ton) }\end{array}$ & $\begin{array}{c}\text { Quantity } \\
\text { (thousand } \\
\text { short tons) }\end{array}$ & $\begin{array}{l}\text { Sulfur } \\
\text { Content } \\
\text { (percent) }\end{array}$ & $\begin{array}{c}\text { Dellivered } \\
\text { Cost } \\
\text { (dollars/ton) }\end{array}$ & $\begin{array}{l}\text { Quantity } \\
\text { (thousand } \\
\text { short tons) }\end{array}$ & $\begin{array}{c}\text { Sulfur } \\
\text { Content } \\
\text { (percent) }\end{array}$ & $\begin{array}{c}\text { Dellvered } \\
\text { Cost } \\
\text { (dollars/ton) }\end{array}$ \\
\hline \multicolumn{10}{|l|}{ Illinols Power } \\
\hline Baldwin ....... & 4,669 & 2.80 & 42.53 & 3,995 & 3.06 & 37.02 & 4,353 & 2.92 & 23.75 \\
\hline Havana ....... & 324 & 0.50 & 58.37 & 496 & 0.66 & 45.33 & 761 & 0.47 & 31.05 \\
\hline Wood River .... & 701 & 0.70 & 66.31 & 738 & 0.86 & 47.66 & 707 & 0.73 & 34.01 \\
\hline Average ...... & - & 2.46 & 45.50 & - & 2.54 & 38.34 & - & 2.39 & 25.82 \\
\hline \multicolumn{10}{|l|}{ Pennsylvania P\&L } \\
\hline Brunner Island . & 3,254 & 1.83 & 62.05 & 3,930 & 1.95 & 52.18 & 2,756 & 1.61 & 39.25 \\
\hline \multicolumn{10}{|c|}{ Potomac Elec. Power } \\
\hline Chalk Point .... & 1,578 & 1.72 & 59.66 & 1,909 & 1.85 & 50.99 & 1,428 & 1.34 & 40.60 \\
\hline Morgantown ... & 1,787 & 1.70 & 59.32 & 2,747 & 1.68 & 51.03 & 2,367 & 1.39 & 41.79 \\
\hline Conemaugh $^{\mathrm{a}} \ldots$ & 387 & 2.23 & 51.94 & 462 & 2.21 & 44.07 & 430 & 2.25 & 28.41 \\
\hline Average ...... & - & 1.76 & 58.70 & - & 1.79 & 50.39 & - & 1.48 & 39.97 \\
\hline \multicolumn{10}{|l|}{ Clnclnnati G\&E } \\
\hline Mlami Fort ...... & 2,627 & 1.75 & 55.16 & 3,269 & 1.70 & 39.93 & 2,663 & 0.82 & 34.76 \\
\hline Beckjord $^{a}$. & 976 & 1.97 & 54.35 & 2,089 & 2.04 & 37.68 & 1,675 & 0.98 & 38.25 \\
\hline Conesville $^{\mathrm{a}} \ldots$. & 541 & 3.47 & 51.87 & 564 & 3.13 & 42.86 & 530 & 2.88 & 34.89 \\
\hline Wansley $^{\mathrm{a}} \ldots$ & 2,296 & 2.59 & 51.76 & 2,472 & 2.57 & 48.72 & 1,499 & 0.88 & 48.20 \\
\hline Yates ........ & 2,520 & 2.37 & 57.74 & 2,676 & 2.02 & 48.60 & 1,235 & 0.90 & 40.26 \\
\hline Gaston $^{\mathrm{a}} \ldots \ldots$ & 1,061 & 1.73 & 68.34 & 1,015 & 2.14 & 52.95 & 1,019 & 0.77 & 42.63 \\
\hline Arkwright ..... & 388 & 2.04 & 66.52 & 194 & 2.09 & 46.87 & 110 & 1.64 & 41.10 \\
\hline Harllee Branch . & 4,081 & 1.24 & 62.73 & 4,000 & 1.26 & 50.22 & 3,546 & 1.13 & 40.08 \\
\hline Mitchell ....... & 534 & 1.36 & 68.57 & 269 & 1.37 & 59.72 & 149 & 1.21 & 58.45 \\
\hline Scherer $^{a} \ldots .$. & 713 & 0.68 & 102.06 & 718 & 0.52 & 49.71 & 2,132 & 0.48 & 34.36 \\
\hline Average $\ldots$. & - & 1.83 & 60.42 & - & 1.70 & 48.83 & - & 0.93 & 39.80 \\
\hline \multicolumn{10}{|c|}{ Southern Indlana G\&E } \\
\hline Culley ... . . . . . & 901 & 3.01 & 46.36 & 1,144 & 2.75 & 39.50 & 1,007 & 3.10 & 25.76 \\
\hline Warrick $^{\mathrm{a}} \ldots \ldots$ & 219 & 3.18 & 43.27 & 149 & 2.87 & 29.39 & 220 & 2.82 & 23.52 \\
\hline Average ..... & - & 3.04 & 45.76 & - & 2.91 & 38.34 & - & 3.05 & 25.36 \\
\hline
\end{tabular}

aThese plants are partially owned by the utillty. The quantity of fuel received represents the utility's portion of the total fuel received at the plant. It should be noted that these date are avallable only at the plant level; therefore, Phase I data cannot be broken out.

$-=$ Not applicable.

Source: Energy Information Administration, Cost and Quality of Fuels for Electric Utility Plants DOE/EIA-0191(various Issues). 
Figure 6. Average Price of Electricity for Six Utilities, 1990-1995

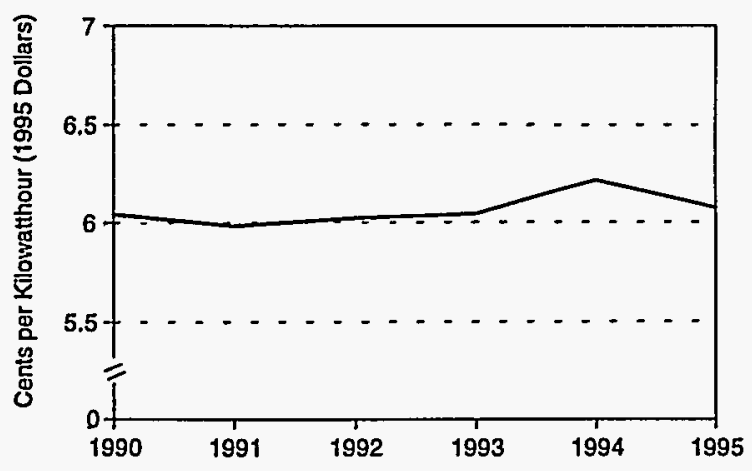

Note: The average is for Pennsylvania Power \& Light, Illinois Power, Potomac Electric Power, Georgia Power, Cincinnati Gas \& Electric, and Southern Indiana Gas \& Electric.

Source: Energy Information Administration, Financial Statistics of Major U.S. Investor-Owned Electric Utilities, DOE/EIA0437(94/1) (Washington, DC, December 1995 and previous years).

and to comply with the Illinois Coal Act. This Act, passed by the Illinois General Assembly in 1991, sought to discourage the use of low-sulfur western-State coal in favor of Illinois high-sulfur coal. In December 1993, the Act was found to be in violation of the Commerce Clause of the U.S. Constitution. This decision was upheld in the U.S. Court of Appeals. IP, acting in response to a forecast of lower allowance prices and anticipating that the Illinois Coal Act would be overruled, announced in August 1992 that it had suspended construction of the Baldwin Power Station scrubbers. In 1993, IP reconsidered its alternatives for compliance.

IP decided to purchase allowances for most of its plants. In 1995, it purchased almost 118,000 vintage $1995 \mathrm{SO}_{2}$ emissions allowances. Also, one substitution unit-Vermilion 1-switched to natural gas, freeing emissions allowances for other plants. The Havana units and Wood River Unit 1 were not operated in 1995, and the few allowances allocated to these units for 1995 were used elsewhere. IP also activated its conditional substitution plan for Wood River 4 in 1995 because actual emissions of the unit were less than its allocation. In 1995, IP acquired enough emissions allowances to meet most of its anticipated needs for 1996; it will purchase additional allowances on the spot market. The Illinois Commerce Commission has approved the recovery of emissions allowance costs through the Uniform Fuel Adjustment Clause; therefore, IP's emissions purchase costs may be added to its retail customer rates.
IP has three Phase I Group I boilers-Baldwin 3, Hennepin 2, and Vermilion 2. To comply with Phase $\mathrm{INO}_{x}$ emission reduction requirements, low-NO $\mathrm{N}_{\mathrm{x}}$ burners were installed at Baldwin 3 and Vermilion 2. Through systemwide averaging, $\mathrm{IP}$ will be able to meet the $\mathrm{NO}_{\mathbf{x}}$ emissions standards for Hennepin 2.

Through 1995, IP spent almost $\$ 63$ million on capital equipment for compliance. However, more than half of that amount-approximately $\$ 35$ million-was expended for the suspended scrubbers. Of course, this increased compliance costs, but perhaps IP will decide to complete the scrubbers later and then the utility will not need to rely as heavily on allowances for compliance. Of the six utilities examined, IP was the only one that used allowances as a primary compliance strategy. Through 1995, IP had spent $\$ 18.5$ million on allowance purchases (classified as O\&M costs in Table 7). They installed 13 continuous emission monitors (CEMS) at a cost of $\$ 15.2$ million and two low $-\mathrm{NO}_{x}$ burners for $\$ 12.7$ million. IP has not developed a compliance strategy for meeting Phase II requirements, but they anticipate additional capital expenditures to comply with the Phase II NO requirements in 2000 and with future State air quality standards for the St. Louis and Chicago metropolitan areas.

\section{Pennsylvania Power and Light Company}

Pennsylvania Power and Light Company (PP\&L), headquartered in Allentown, Pennsylvania, owns 8.7 gigawatts of capacity. Two gigawatts of PP\&L's generating capacity were designated as Phase I Table 1 affected units. Unlike many other Phase I utilities, PP\&L did not participate in the substitution or compensation programs.

PP\&L switched to lower sulfur coal at its owned and operated units to meet its Phase I obligations in 1995. Because of a general decline in coal prices throughout the United States, PP\&L did not incur higher fuel prices for lower sulfur coal. From 1985 to 1995, the delivered cost of coal for PP\&L's Phase I units decreased from $\$ 57.30$ per ton to $\$ 34.30$ per ton, while the average sulfur content fell from 1.77 percent to 1.52 percent. PP\&L's Phase I units showed no major shifts to coal suppliers outside of Pennsylvania. Over the past 5 years, however, PP\&L reduced its purchases of Central Pennsylvania coal, and increased its purchases of lower sulfur coal from western Pennsylvania. They also received a small amount from Utah and West Virginia in 1995. To meet the $\mathrm{NO}_{x}$ emissions requirements, $\mathrm{PP} \& \mathrm{~L}$ installed low- $\mathrm{NO}_{x}$ burners on all its Phase I units and submitted a plan for systemwide $\mathrm{NO}_{x}$ averaging. 
PP\&L's Phase II compliance strategy will be similar to its Phase I strategy. PP\&L plans to purchase lower sulfur coal, to utilize banked allowances, and to purchase additional emissions allowances as needed. PP\&L does not plan to use scrubbers for its plants. As a hedge against the uncertainty of future compliance market conditions, PP\&L, as part owner of the Conemaugh plant, will take advantage of its share of allowances generated by Conemaugh's scrubbers. PP\&L estimates that further Title IV compliance operating costs will be incurred beyond 2000 in amounts that are not now determinable but could be material.

PP\&L spent a total of $\$ 51.2$ million on equipment for Phase ISO $\mathrm{S}_{2}$ emissions compliance. However, $\$ 41$ million of this is attributable to its share of scrubbing equipment at the Conemaugh plant. The utility spent $\$ 70.7$ million on low-NO $\mathrm{N}_{\mathrm{x}}$ burners and $\$ 11.1$ million on CEMS. PP\&L's average cost of Phase I compliance per kilowatt of affected capacity was $\$ 56.76$.

\section{Potomac Electric Power Company}

The Potomac Electric Power Company (PEPCO) is headquartered in Washington, DC. It owns 6.4 gigawatts of capacity. Four units at two power plants-Chalk Point and Morgantown - with 1.8 gigawatts of capacity, were designated as Phase I Table 1 affected units. Additionally, PEPCO owns 9.7 percent of the 2 Table 1 units at the Conemaugh plant in Pennsylvania. PEPCO decided that switching to lower sulfur coal would provide the best strategy for complying with Title IV $\mathrm{SO}_{2}$ limits. No significant capital costs are associated with switching to lower sulfur coal at Chalk Point. In fact, the cost of its delivered coal fell from $\$ 58.70$ per ton to $\$ 39.97$ per ton, while the average sulfur fell from 1.76 percent to 1.48 percent during the same time period. Although the mix of PEPCO's coal supply for Table 1 units changed, its coal came from Pennsylvania, Maryland, and West Virginia in 1995-the same as in 1985.

By using lower sulfur coal as its primary $\mathrm{SO}_{2}$ compliance strategy, excess allowances were accumulated at these plants. Also, Chalk Point 4 was designated as a substitution unit for Chalk Point units 1 and 2, and Chalk Point 3 was designated as a substitution unit for Morgantown units 1 and 2. PEPCO indicated that the marginal cost of adding these units to Phase I was $\$ 3.2$ million, for installation of CEMS. However, by designating these substitution units, PEPCO obtained additional emissions allowances that can be banked for later use. To meet $\mathrm{NO}_{\mathrm{x}}$ emissions requirements, $\mathrm{PEPCO}$ installed low- $\mathrm{NO}_{x}$ burners on all its coal-burning units; because both substitution units burn petroleum, low-NO $\mathrm{N}_{\mathrm{x}}$ burners were not installed on them.

Phase I capital compliance costs for PEPCO total $\$ 196$ million. Like PP\&L, most of these costs are a result of the installation of low- $\mathrm{NO}_{x}$ burners, and more than half of the capital spent on $\mathrm{SO}_{2}$ control went toward its share of Conemaugh's scrubbers. Another large portion of the expenditures was incurred in adding gas-fired capacity to Chalk Point units 1 and 2 ( $\$ 30$ million). PEPCO spent almost $\$ 13$ million on CEMS. The per kilowatt capital cost for PEPCO's total Title IV compliance was $\$ 56.27$, which was quite similar to PP\&L's $\$ 56.76$ per kilowatt.

For future compliance actions, PEPCO may continue to burn lower sulfur coal or low-sulfur oil. Scrubbing is also a possibility for meeting future emissions reductions requirements. One possible strategy is fuel switching for Phase I and scrubbing for Phase II. This strategy avoids the high capital costs of installing scrubbers for as long as possible.

\section{Cincinnati Gas and Electric Company}

Cincinnati Gas and Electric Company (CG\&E) serves Ohio with power from the nine plants in which it has ownership interest. These nine plants have a total nameplate generating capacity of about 5.3 gigawatts. Initially, 25 percent of the utility's total capacity was affected by Phase I. With the addition of five substitution units, Phase I capacity increased to 50 percent of total generating capacity.

In October 1994, CG\&E and PSI Energy merged to form the CINergy Corporation, a holding company registered under the Public Utility Holding Company Act of 1935. CG\&E's compliance plan was in place in late 1994, and the merger did not cause significant changes to the plan. CG\&E and PSI will prepare a joint compliance plan for Phase II.

To meet the $\mathrm{SO}_{2}$ emissions reduction requirements, CG\&E switched to lower sulfur coal at the Miami Fort, Beckjord, and J.M. Stuart plants. Electrostatic precipitator modifications were made on Beckjord unit 5 and on Miami Fort unit 6. $\mathrm{An} \mathrm{SO}_{3}$ injection system was installed on Miami Fort unit 7 to accommodate the lower sulfur coals. The average sulfur content of coal received at these plants in 1995 was 0.88 percent, down from 1.64 percent in 1985. The average sulfur content of coal received at all of CG\&E's Phase I plants, including those that did not switch to lower sulfur coal, decreased from 1.92 percent in 1985 to 1.21 percent in 1995. 
To accumulate extra emissions allowances, CG\&E designated East Bend Power Plant Unit 2 a substitution unit. This unit originally entered commercial operation in 1981, and a scrubber had been installed in 1980 . By designating East Bend 2 a substitution unit, CG\&E obtained overcompliance allowances that can be used for other units. $\mathrm{SO}_{2}$ emissions in 1995 at Conesville unit 4, which is a jointly-owned unit, were higher than its allowance allocation; therefore, excess allowances from other units were applied to this unit.

For short-term contingencies, CG\&E intends to build an operating reserve of $\mathrm{SO}_{2}$ allowances containing about 13 percent of annual allotments. Extra allowances will come from overcompliance at some units and from participation in the allowance markets. CG\&E purchased allowances in the 1993 and 1994 EPA allowance auctions; no purchases were made in the 1995 and 1996 auctions.

Through 1995, CG\&E spent approximately $\$ 23$ million on capital equipment for compliance with Title $I V$, and its average capital costs are $\$ 16.91$ per kilowatt of affected capacity. This expenditure is relatively low compared to the other 5 utilities, primarily because the costs for East Bend's unit 2 scrubber were not included. Also, because of its original low- $\mathrm{NO}_{x}$ design, the East Bend plant did not require $\mathrm{NO}_{x}$ modifications to meet $\mathrm{NO}_{\mathrm{x}}$ emission requirements.

Modifications to burn lower sulfur coal at the Beckjord and Miami plants have cost about \$12.4 million. Capital costs for low- $\mathrm{NO}_{\mathrm{x}}$ burners at the Beckjord plant were $\$ 6.9$ million. Miami Fort 7 and J.M. Stuart units 1 through 4 have been designed with cell burner technology which is exempt from Phase I NO limits. Interestingly, the cell burners at the Stuarts units were installed as part of the Clean Coal Project, which was funded by the U.S. Department of Energy (DOE). Conesville 4 is able to meet $\mathrm{NO}_{x}$ limits by taking its high $\mathrm{NO}_{x}$ emitting burners out of service.

CG\&E has spent $\$ 3.5$ million on CEMS, but they expect to incur more costs as final project enhancements are implemented and software modifications required by the EPA are made.

CINergy is investigating alternatives to meet Phase II requirements. Its current allowance banking strategy allows them to defer plant modifications for reducing $\mathrm{SO}_{2}$ emissions. CINergy intends to submit a system-wide $\mathrm{NO}_{x}$ averaging plan to meet Phase II requirements.

\section{Georgia Power Company}

The Georgia Power Company (GPC) is an operating company of Southern Company, a registered holding company headquartered in Atlanta, Georgia. Southern's other operating companies are Alabama Power, Mississippi Power, Savannah Power, and Gulf States Power. GPC owns 16 gigawatts of capacity at 33 plants and 7.6 gigawatts of GPC-owned-and-operated capacity at 5 plants, which were designated as Phase I Table 1 affected units. Georgia Power owns 53.5 percent of the Wansley plant, a Table 1 unit, and 75 percent of Scherer Unit 3, a substitution plant; GPC operates both Wansley and Scherer. Additionally, GPC owns 50 percent of units 1 through 4 at the EC Gaston plant, operated by Alabama Power, which were designated Phase I Table 1 affected units.

GPC's basic compliance strategy was integrated into the Southern Company's overall plan. GPC's primary method of compliance with Phase I requirements was to increase burning of lower sulfur coal. In 1994, GPC was the recipient of more coal than all but three utilities (Tennessee Valley Authority, PacifiCorp, and Texas Utilities Electric Company). Clearly, any changes in GPC's coal consumption patterns can have significant effects on the coal market. Yates unit 1 installed a scrubber at an estimated cost of $\$ 34$ million, one-half of which was funded by DOE. GPC also substituted 10 Phase II units into Phase I and employed a reduced utilization plan, including increased unit efficiency and sulfur-free generation.

GPC's switch to lower sulfur coal required some equipment upgrades. Switching fuels-from an approximate mix of 1.5 percent high-sulfur coal from the Illinois basin to lower sulfur sources from central Appalachia-allowed GPC to overcomply and accumulate unused emissions allowances that were banked for future use. Additionally, the Scherer plant received subbituminous coal from $W y o m i n g$. The average delivered cost of GPC's coal fell from an average of $\$ 60.42$ per ton in 1985 to $\$ 39.80$ per ton in 1995. During the same period, the average sulfur content of the coal received at GPC's Phase I plants fell from 1.83 percent to 0.93 percent. Compliance with the acid rain $\mathrm{NO}_{x}$ emissions reduction requirements was achieved through the installation of new control equipment at 18 of the original 33 affected boiler units.

Construction expenditures for GPC's share of Phase I compliance totaled approximately $\$ 189.6$ million through 
1995. Most of this total, $\$ 125$ million, was allocated to the installation of low-NO $\mathrm{N}_{x}$ burners. The largest expenditure for $\mathrm{SO}_{2}$ control was GPC's $\$ 17$ million share for the scrubber at Yates unit 1. GPC so far has spent $\$ 17$ million on CEMS for Phase I. On a per-kilowatt basis, GPC's capital costs for affected Phase I compliance are $\$ 18.48$.

Georgia Power and the Southern Company's plan to comply with Phase II are uncertain at this point. Various options are being considered including using banked emissions allowances, continued use of fuel switching, installing scrubbers at selected plants, and/or purchasing more allowances, depending on their price and availability. In Phase II, equipment to control $\mathrm{NO}_{x}$ emissions will be installed on additional system fossil-fired plants as required to meet anticipated Phase II limits. From 1996 to 2000 , the current compliance strategy may require total construction expenditures of approximately $\$ 45$ million. However, GPC realizes that the full impact of Phase II compliance cannot be determined with certainty; much depends on the continuing development of a market for emission allowances, the completion of EPA regulations, and the possibility of new emission reduction technologies. The bottom line is that much uncertainty still exists regarding Phase $I$, and GPC wants to remain as flexible as possible. Phase I and Phase II are not distinct. Rational utilities will not isolate the two but will integrate their Phase I and Phase II plans to form an overall compliance plan.

An increase of up to 1 percent in GPC's annual revenue requirements could be necessary to fully recover the cost of compliance for both Phase I and Phase II. Compliance costs include construction expenditures, modification costs to facilitate switching to lower sulfur coal, and costs related to emissions allowances. GPC expects to recover a significant portion of these costs through existing ratemaking provisions. However, GPC states there are no assurances that all Clean Air Act costs will be recovered.

\section{Southern Indiana Gas and Electric Company}

Southern Indiana Gas and Electric Company (SIGECO) is a relatively small investor-owned utility serving Indiana with a total of 1.4 gigawatts of generating capacity from five power plants. Two units at the Culley Power Plant and one unit (partially owned) at the Warrick Plant are Table 1 units. SIGECO's ownership share of the affected units is 530 megawatts of capacity. Interestingly, two of SIGECO's principal coal-fired facilities (A.B. Brown Units 1 and 2) had been equipped with scrubbers and were not significantly affected by the CAAA90.
To reduce $\mathrm{SO}_{2}$ emissions, SIGECO installed a single scrubber at the Culley Generating Station serving both Culley 2 and Culley 3 . Construction of the scrubber started in 1992, and it went in-service on February 1, 1995. Because of the scrubber, SIGECO overcomplied at the Culley Power Plant and has allowances that can be sold to other parties or banked to meet future emissions reductions requirements. Some of the allowances from the Culley Plant were applied to the $\mathrm{SO}_{2}$ emissions from the Warrick Plant. To meet Phase I NO emissions requirements, SIGECO installed low- $\mathrm{NO}_{\mathrm{x}}$ burners at the Culley Plant. The Warrick Plant utilizes cell burner technology and is not affected by the Phase $\mathrm{INO}_{\mathrm{x}}$ emissions standards.

A federal court overturned parts of an Indiana law that was designed to encourage State utilities to use Indiana coal to meet $\mathrm{CAAA} 90 \mathrm{SO}_{2}$ requirements. The December 1995 decision-like several other recent cases-rules that the law violates the U.S. Constitution's Commerce Clause because it provides Indiana coal suppliers with an unfair advantage over coal mined in other States. Although recently overturned, this law perhaps influenced SIGECO to install scrubbers instead of using the more popular fuel switching strategy. In any event, by continuing to use less expensive high-sulfur coal, SIGECO reduced their real costs of fuel 34 percent from 1990 to 1995.

Through 1995, SIGECO has spent about $\$ 111$ million on capital equipment for compliance, most of which, $\$ 103$ million, was spent for the Culley Power Plant scrubber. SIGECO estimates that it will cost approximately $\$ 4$ million annually to operate and maintain the scrubber, including the costs of chemicals used in the process. Costs for scrubber maintenance are offset somewhat by selling gypsum, which is a byproduct of scrubbing. SIGECO produces approximately 20 tons of gypsum per hour on average. About $\$ 5$ million was spent on $\mathrm{NO}_{\mathrm{x}}$ control equipment, and $\$ 2.8$ million was spent on the installation of CEMS. The average capital cost through 1995 was about $\$ 209$ per kilowatt affected by Phase I.

The majority of SIGECO's generating capacity is already positioned to comply with the Phase $\mathrm{II} \mathrm{SO}_{2}$ emissions reductions requirements. Sixty-six percent of its generating capacity has scrubbers. SIGECO plans to purchase emissions allowances and/or to blend lower sulfur coal with coal of a higher sulfur content for the remaining capacity. Meeting $\mathrm{NO}_{\mathrm{x}}$ standards is more problematic. SIGECO's largest plant, the A.B. Brown Power Plant, is currently in compliance with the $0.5 \mathrm{lbs}$ per million Btu $\mathrm{NO}_{x}$ limits. However, if this standard is lowered, equipment retrofits will be needed to comply. To meet the $\mathrm{NO}_{x}$ standards at Warrick 4, SIGECO is installing low-NO ${ }_{x}$ burners, which will cost an estimated $\$ 4$ million. 


\section{Conclusions Drawn From These Case Studies}

Utilities employ a variety of strategies for complying with the CAAA90 Title IV requirements. For 1995, most of the 6 utilities' units were switched to lower sulfur coal to meet the $\mathrm{SO}_{2}$ emissions limitations. Because of declining coal prices, none of these utilities paid more for low-sulfur coal in 1995 than they paid for high-sulfur coal in previous years. ${ }^{30}$

Although their price has declined from levels estimated in the early 90 's, only a few scrubbers were installed because they are expensive relative to other compliance methods. Designation of substitution units, which generated extra emissions allowances in most instances, was used extensively by utilities. By exceeding the required emissions reductions, most utilities have excess $\mathrm{SO}_{2}$ emissions allowances, which they have banked or traded.
Some industry observers thought that compliance with Title IV would cause electricity prices to increase. A closer examination suggests that compliance has not caused electricity prices to increase, at least for the six utilities examined in this report. Since 1990, which is 5 years prior to the start of the program, real electricity prices of the six utilities have remained relatively stable at about 6 cents per kilowatthour. Prices increased slightly in 1994, but returned to previous levels in 1995. Admittedly, this is a rough analysis, and the effect on prices of future compliance requirements remains to be seen.

For the most part, the six utilities discussed here do not have firm plans for meeting Phase II requirements. Most of them are delaying large capital expenditures, while banking extra allowances as a hedge for the future.

${ }^{30}$ One could argue that regardless of declining coal prices, the difference in price between higher sulfur and lower sulfur coal represents a fuel premium. Because of the volatility of coal prices in today's market, however, the six utilities were not asked to estimate a lower sulfur coal premium. 


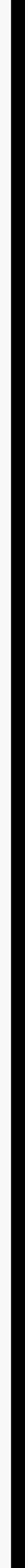




\section{Phase I Effects on Coal Supply and Demand}

\section{Compliance and Fuel Costs}

Despite the increased demand for lower sulfur coal brought on by Phase I compliance programs, the average delivered price of lower sulfur coal (as well as higher sulfur coal) declined between 1990 and 1995. The delivered price of coal generally includes the mine price, transportation costs, and shipping and loading fees and may account for as much as 75 percent of the operating costs at an electric utility plant. ${ }^{31}$ The recent decline in coal prices can be attributed to lower mine prices and lower transportation costs.

New and improved mining technologies such as longwall mining have increased coal mining productivity by almost 7 percent per year between 1990 and 1995. Also, transportation costs for coal purchased under contract have fallen for all modes of transportation in the last decade. Although transportation cost as a percentage of delivered cost varies greatly across different coal demand and supply regions because it is influenced by shipping distance, contract coal transportation costs are a significant portion of the average delivered cost of coal on average, accounting for 31 percent of the average delivered price of contract coal in the United States in $1993 .^{32}$ Transportation costs have fallen for varying reasons in different coal supply regions-in the West because of increased competition among railroads and substantial productivity gains made by railroads, and in the East because of an increase in low-cost barge shipments. ${ }^{33}$ These declines, along with electric utilities' renegotiation of long-term contracts, may have caused the average delivered price of lower sulfur coal from almost every producing State to decrease between 1990 and 1995 (Table 9). The availability of low-cost, lower sulfur coal may have induced utilities to burn more lower sulfur coal, resulting in a greater reduction of $\mathrm{SO}_{2}$ emissions and more allowance credits earned.
Table 9. Average Delivered Cost of Low-Sulfur Coal by Origin State, 1985, 1990, and 1995 (1995 Dollars Per Short Ton)

\begin{tabular}{|c|c|c|c|}
\hline State & 1985 & 1990 & 1995 \\
\hline Alabama .......... & 72.89 & 61.22 & 47.00 \\
\hline Arizona . . . . . . . . . & 27.44 & 27.29 & 24.67 \\
\hline Colorado ........ & 50.45 & 35.14 & 28.83 \\
\hline Illinois . . . . . . . . . & 51.39 & 50.20 & 35.77 \\
\hline Indiana .......... & 47.85 & 37.05 & 28.43 \\
\hline Kentucky (eastern) . & 64.55 & 48.60 & 38.98 \\
\hline Kentucky (western) . & 63.58 & 34.64 & 26.28 \\
\hline Louisiana . . . . . . . & 31.52 & 21.10 & 17.97 \\
\hline Maryland ........ & 48.29 & 45.89 & 36.79 \\
\hline Missouri . . . . . . . . & 52.80 & $-{ }^{a}$ & $--^{a}$ \\
\hline Montana .......... & 42.08 & 28.32 & 23.14 \\
\hline New Mexico ....... & 35.01 & 32.31 & 28.81 \\
\hline North Dakota ..... . & 16.56 & 11.07 & 9.71 \\
\hline Ohio ........... & 49.87 & 38.68 & 36.00 \\
\hline Oklahoma ........ & 63.73 & 41.98 & 33.84 \\
\hline Pennsylvania ..... . & 52.86 & 44.60 & 35.84 \\
\hline Tennessee ........ & 57.15 & 42.82 & 33.82 \\
\hline Texas ............ & 17.13 & 15.93 & 13.53 \\
\hline Utah ........... & 53.39 & 31.54 & 26.56 \\
\hline Virginia $\ldots \ldots \ldots$ & 68.74 & 50.96 & 40.63 \\
\hline W. Virginia $(\mathrm{N}) \ldots \ldots$ & 61.44 & 48.15 & 36.07 \\
\hline W. Virginia (S) ..... & 66.09 & 47.39 & 37.93 \\
\hline Washington ...... & 37.05 & 29.78 & 23.61 \\
\hline Wyoming ........ & 40.08 & 26.43 & 20.45 \\
\hline U.S. Average . . . . . . & 46.25 & 33.83 & 27.00 \\
\hline
\end{tabular}

a Low-sulfur coal sales less than 1 million tons.

Note: Low-sulfur coal is defined to have less than or equal to 2.5 pounds of $\mathrm{SO}_{2}$ per million Btu.

Source: Federal Energy Regulatory Commission (FERC) Form 423, "Monthly Report of Cost and Quality of Fuels for Electric Plants."

\footnotetext{
31 "Fuel Flexibility Underpins Gibson's Long Range Plans,"Power (April 1995).

32 Energy Information Administration, Energy Policy Act Transportation Rate Study: Interim Report on Coal Transportation, DOE/EIA-0597 (Washington, DC, October 1995), p. 62.

${ }^{33}$ Energy Information Administration, Energy Policy Act Transportation Rate Study: Interim Report on Coal Transportation, DOE/ELA-0597 (Washington, DC, October 1995), p. 73.
} 


\section{Compliance and Coal Supply}

In 1995, the Powder River Basin (PRB) was the leading coal supply region, producing 303.3 million tons of coal (29 percent of U.S. coal production), while the central Appalachian region was second in coal production at 269.5 million tons (26 percent) (Table 10). After leading the nation in coal production for many years, the central Appalachian region slipped to second in 1994 as utilities found that PRB was a low-cost source of lower sulfur coal that could often be burned without significantly reducing the efficiency of their plants. ${ }^{34}$ PRB produces a lower sulfur, low-Btu subbituminous coal, which can be economically mined and transported, while a lower sulfur, high-Btu bituminous coal originates from the central Appalachian region, where recoverable reserves are limited and more difficult to mine. Northern Appalachia and the Illinois basin, with relatively high sulfur and high-Btu coal, produced 13 percent and 11 percent of total coal production, respectively, in 1995. ${ }^{35}$ The Rocky Mountains are a primary source of lower sulfur bituminous coal for electric utilities in the Midwest and accounted for 5 percent of total coal produced in the United States in 1995. ${ }^{36}$

Because fuel switching and blending has proven to be the most popular Phase I compliance method, shifts from higher sulfur coal regions to lower sulfur coal regions have occurred. In 1990, low-to-medium sulfur coal accounted for 67 percent of total coal receipts at electric utilities, increasing to 77 percent by 1995 . Consequently, high-sulfur coal decreased from 33 percent in 1990 to 23 percent in $1995 .^{37}$

Of the three coal supply regions with large lower sulfur reserves-the central Appalachian region (including Virginia, eastern Kentucky, and southern West Virginia), PRB (including Wyoming and Montana), and the Rocky Mountains (including Colorado and Utah)-PRB and the Rocky Mountains increased total coal sales dramatically between 1990 and 1995, while central Appalachia's total coal sales increased marginally ( 6 percent) (Table 11 ). Central Appalachia, once thought to be the most popular choice for lower sulfur coal by the Phase I plants, increased its lower sulfur coal sales by 15 million tons as its higher sulfur coal sales fell by 5 million tons. Most of the increase was from southern West Virginia. Lower sulfur coal receipts originating from PRB in 1995 increased by 78 million tons over coal receipts from PRB in 1990, which amounted to a 37-percent increase. For Wyoming, total coal sales increased by 77 million tons between 1990 and 1995 (Table 11). Wyoming coal was shipped to 18 States in 1995, as far east as Indiana and as far south as Georgia. Several States significantly increased purchases of Wyoming coal between 1990 and 1995 (Figure 7). Missouri led with an increase of 18 million tons. Lower sulfur coal receipts from the Rocky Mountains increased by almost 10 million tons from 1990. Total coal receipts from the northern Appalachian region fell from 127 million short tons in 1990 to 103 million short tons in 1995 (a 19-percent decrease). Northern Appalachia was able to increase its lower sulfur coal sales by 5 million tons, but not enough to offset the decline of 29 million tons in higher sulfur coal sales. Total coal receipts from the Illinois Basin dropped to 96 million short tons in 1995 from 129 million tons in 1990 (26 percent). The Illinois basin was able to double its lower sulfur coal sales from 1990 to 1995; however, its higher sulfur coal sales dropped by 40 million tons at the end of 1995 .

\section{Compliance and Coal Demand}

One general perception of the outcome of Phase I of Title IV is that compliance has been less costly for electric utilities than projected because the price of allowances has dropped and lower sulfur coal prices have not increased as projected. However, just as this legislation has stimulated the energy markets by producing winners with innovative and cost-saving compliance methods, it has also resulted in losses in the higher sulfur coal supply regions where there are few options to improve the productive capability and the marketability of higher sulfur coal. This section of the report compares four broad coal demand regions-the Midwest, Northeast, South, and West (each a combination of the U.S. census divisions) (Figure 8)-to observe the significant differences in coal receipts, coal suppliers, transportation costs, and employment in these regions during the 1990's. Particular attention is given to those coal-producing States with a large number of Phase I generating units to observe shifts in coal supply sources due to compliance. Reductions in mining jobs and the number of operating mines discussed in this section are primarily attributable to productivity gains in the mining industry resulting from the closing of inefficient, uneconomical mines and the more efficient

${ }^{34}$ Fossil Plant News, Fall 1996, p. 3.

${ }^{35}$ Energy Information Administration, Coal Industry Annual 1995, DOE/EIA-0584(95) (Washington, DC, October 1996), pp. 90-101.

${ }^{36}$ Energy Information Administration, Energy Policy Act Transportation Rate Study: Interim Report on Coal Transportation, DOE/EIA-0597 (Washington, DC, October 1995), p. 11.

${ }^{37}$ Federal Energy Regulatory Commission, Form 423, "Monthly Report of Cost and Quality of Fuels for Electric Plants." 
Table 10. Coal Production by State, 1990 and 1995 (Thousand Short Tons)

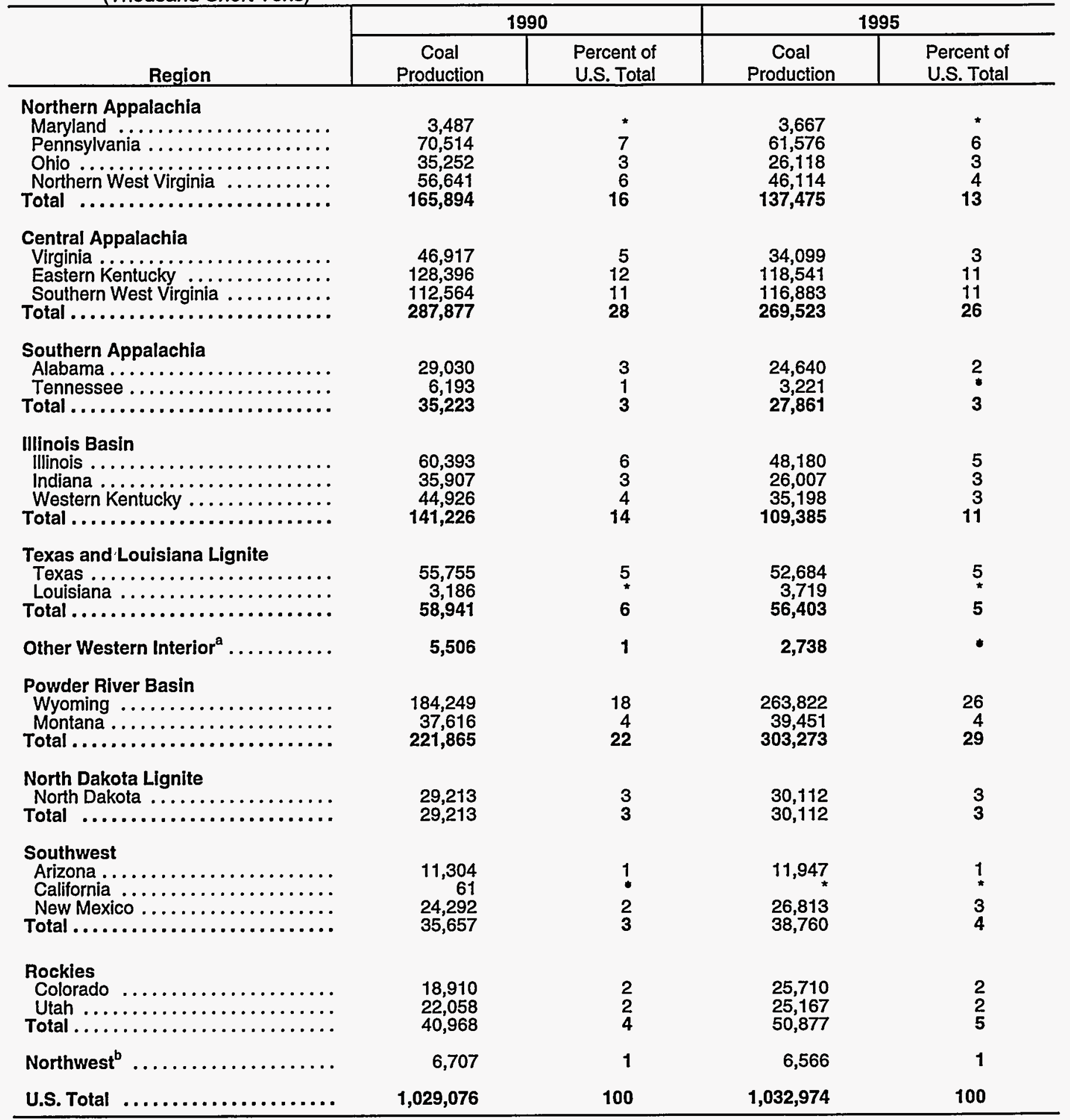

Includes lowa, Oklahoma, Kansas, Arkansas, and Missouri.

Includes Alaska and Washington.

$=$ Less than 0.5 percent.

Note: Totals may not equal sum of components because of independent rounding.

Source: Energy Information Administration, Coal Industry Annual 1995, DOE/EIA-0584(95) (Washington, DC, October 1996), pp. 90-101. 
Table 11. Coal Receipts at Electric Utility Plants by Supply Region and Sulfur Dioxide Level, 1990 and 1995

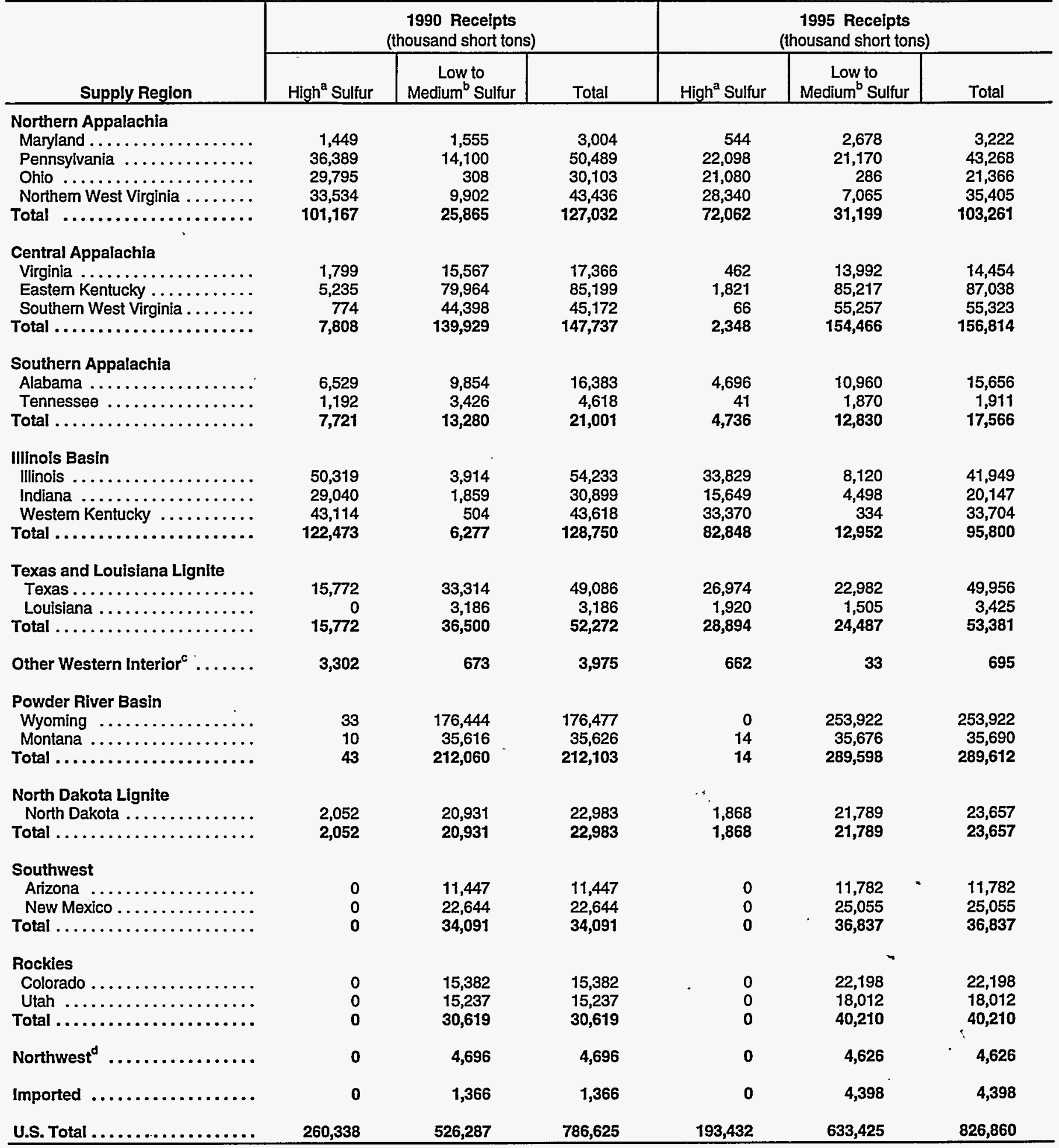

aHigh sulfur level is greater than 2.5 pounds of sulfur per million Btu's.

bow-to-medium sulfur level is less than or equal to 2.5 pounds of sulfur per million Btu's.

Includes lowa, Oklahoma, Kansas, and Missouri.

Includes Alaska and Washington.

Source: Federal Energy Regulatory Commission (FERC) Form 423, "Monthly Report of Cost and Quality of Fuels for Electric Plants." 
Figure 7. Coal Produced in Wyoming and Delivered to Electric Utilities, 1990 and 1995

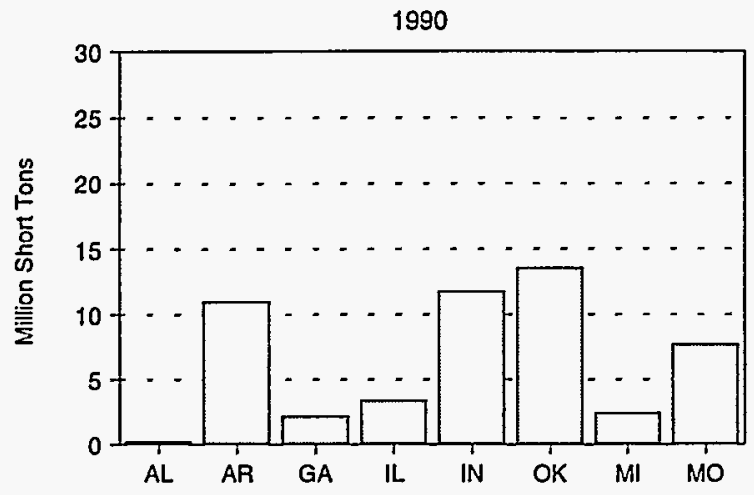

1995

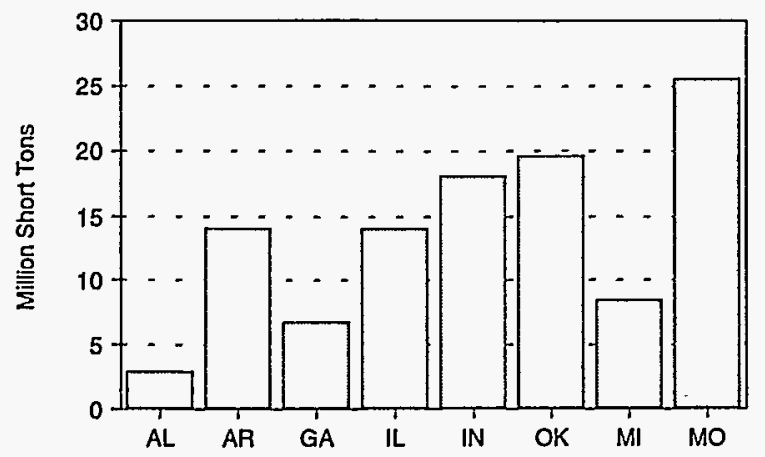

Source: Energy Information Administration, Cost and Quality of Fuels for Electric Utility Plants 1990, DOE/EIA0191 (Washington, DC, August 1991), Table 33 and Federal Energy Regulatory Commission (FERC) Form 423, "Monthly Report of Cost and Quality of Fuels for Electric Plants."

operation of existing mines. Shifts in coal supply sources brought on by compliance with Phase I has a smaller impact on these statistics.

\section{The Midwest Demand Region}

The Midwest, made up of the East North Central and West North Central census divisions, had 134 Table 1 units with 42.8 gigawatts of capacity. In 1995, the Midwest was the second largest recipient of coal of the four regions, with 302 million tons; the region received about 24 million tons more than in 1990.

Railroads, the major mode of transporting coal purchased under contract to this region, were able to reduce rail transportation costs between 1988 and 1993 because of rail productivity increases and because coal transporters in certain regions renegotiated contracts with utilities to maintain market shares where possible. In 1990, five States in the Midwest-Illinois, Indiana, Michigan, Ohio, and Missouri-received more than 64 percent of the coal received in the region.

\section{The State of Illinois}

Coal is abundant in Illinois and is the most valuable mineral resource, exceeding crude oil and natural gas in estimated total value. Underlying about two-thirds of the State in relatively thick, flat-lying coalbeds, the coal is bituminous in rank and has a high-sulfur content, averaging 2 to 3 percent by weight even when cleaned. ${ }^{38}$ In 1990, Illinois produced 60.4 million tons of coal, ${ }^{39}$ selling 15.5 million tons in the State. A large share was sold to Missouri (12.4 million tons) and Indiana (9.7 million tons).$^{40}$ Two-thirds of the coal produced in Illinois is from underground mines, most of which are large operations.

In choosing between scrubbing and switching, the four Illinois utilities with 17 Table 1 units were faced with an important economic decision that affected both the utilities and the State: Illinois coal could continue to be used; however, switching to lower sulfur coal meant obtaining coal from sources outside of Illinois, thus reducing the demand for a valuable State resource.

In 1991, the Illinois State legislature passed a clean air law to protect Illinois coal producers. The law required utilities to inform the State whether their Title IV plans included use of Illinois coal before State approval was granted. Similar laws were passed in Indiana, Oklahoma, and Ohio. However, the Alliance for Clean Coal, a coalition of western coal producers and railroads, filed suit $^{41}$ against the Illinois clean air law, arguing that it violated Federal interstate commerce statutes; the Alliance succeeded in having the Illinois law struck down. The

${ }^{38}$ Energy Information Administration, State Coal Profiles, DOE/EIA-0576 (Washington, DC, January, 1994), p. 27.

39 Energy Information Administration, Coal Industry Annual 1994, DOE/EIA-0584 (Washington, DC, October 1995), p. 5.

40 Energy Information Administration, Cost and Quality of Fuels for Electric Utility Plants 1990, DOE/ELA-0191 (Washington, DC, August 1991), p. 56.

41 Alliance for Clean Coal vs. Craig, Docket No. 93C4391, December 15, 1993. 
Figure 8. Coal Demand Regions

West

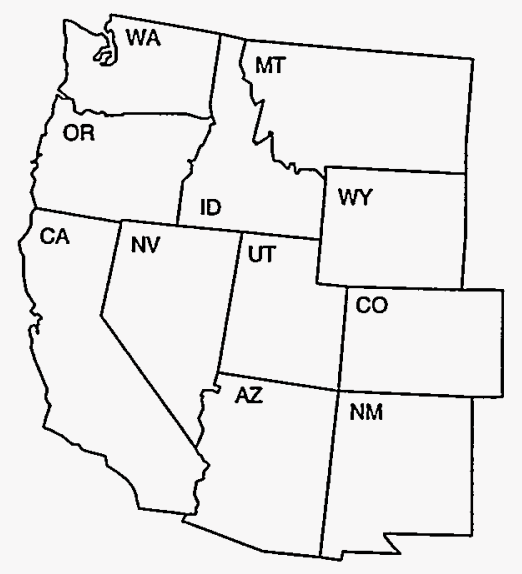

Midwest

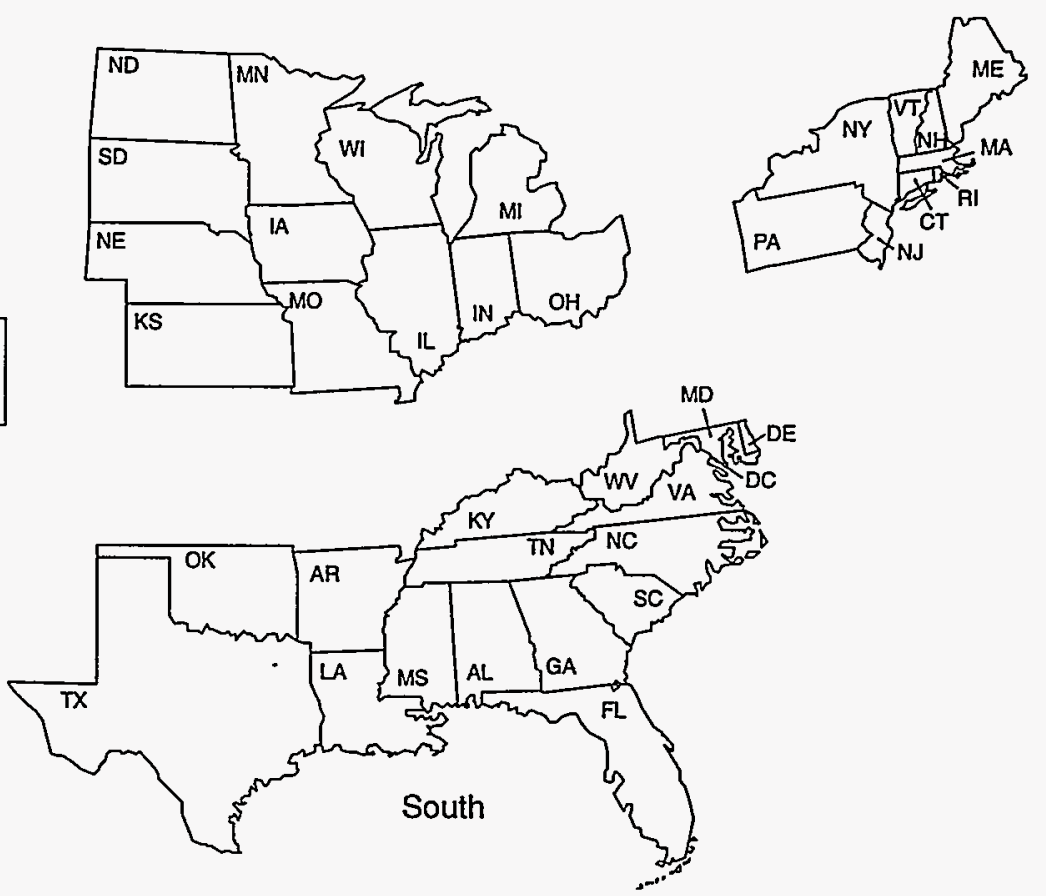

\section{Coal Demand Regions}

Northeast

Connecticut

Maine

Massachusetts

New Hampshire

New Jersey

New York

Pennsylvania

Rhode Island

Vermont
Midwest

Illinois

Indiana

lowa

Kansas

Michigan

Minnesota

Missouri

Nebraska

North Dakota

Ohio

South Dakota

Wisconsin
South

Alabama

Arkansas

Delaware

District of Columbia

Florida

Georgia

Kentucky

Louisiana

Maryland

Mississippi

North Carolina

Oklahoma

South Carolina

Tennessee

Texas

Virginia

West Virginia

Northeast 
Alliance won a similar suit in Indiana $\mathrm{a}^{42}$ and filed a suit against the Ohio law in September 1995. ${ }^{43}$

Illinois coal production in 1995 fell to 48.2 million tons (about 11.9 million tons were used in the State). One of Illinois' main consumers, Missouri, purchased only 4.2 million tons, a reduction of 8 million tons from 1990, and Indiana received 10.7 million tons, a slight increase from 1990. As consumers, the electric utilities in both Illinois and Missouri in 1995 substituted a substantial amount of lower sulfur coal from Wyoming for coal from Illinois-Illinois received 14 million tons from Wyoming (Figure 9) and Missouri increased its purchases from Wyoming by 17.9 million tons. Between 1990 and 1995, the number of operating mines in Illinois dropped from 45 to 31 , while the average number of miners decreased on average by 11 percent per year between 1990 and 1995 $(10,018 \text { to } 5,652)^{44}$

\section{The State of Indiana}

In 1995, Indiana produced 26 million tons of coal, ${ }^{45}$ almost 10 million tons less than in 1990 . Nearly all of the coal was obtained from surface mines-bituminous in rank and high in sulfur content. Second only to Texas in annual consumption, Indiana is a large consumer of coal, using about three-fifths of coal produced in the State. ${ }^{46}$

Indiana's excellent rail network and sophisticated port facilities on Lake Michigan to the north and on the Ohio River to the south make coal delivery to Indiana utilities easy, but also makes the State vulnerable to penetration by lower sulfur western coal. ${ }^{47}$

Because of the higher sulfur content of Indiana coal, Indiana utilities affected by Phase I ( 15 plants housing 37 units) had to either scrub or modify their boiler units to burn lower sulfur coal from other States. As of December 1995, utilities in the State installed scrubbers on seven units at four plants and constructed a coal gasification combined cycle project at the Wabash River Plant. This clean coal technology project at Wabash River removes 98 percent of the $\mathrm{SO}_{2}$ from 2,700 tons of high-sulfur bituminous coal each day. These compliance choices have
Figure 9. Origin of Coal Received in Illinois, 1990 and 1995
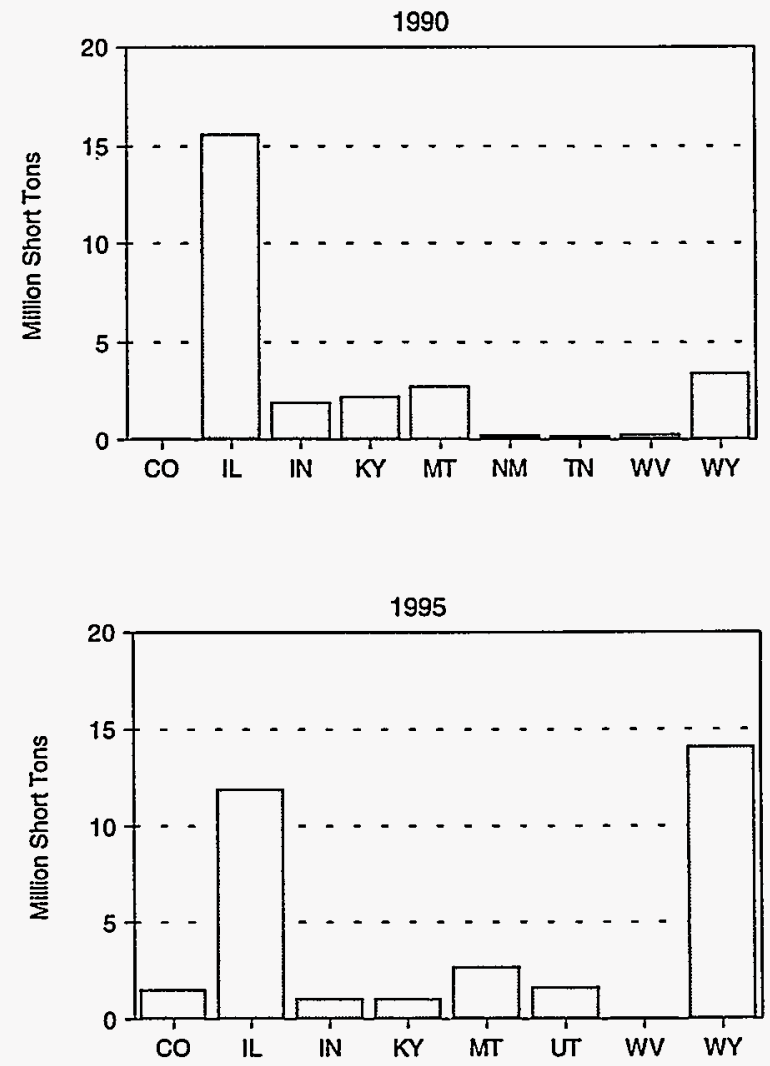

Sources: Energy Information Administration, Cost and Quality of Fuels for Electric Utility Plants 1990, DOE/EIA(Washington, DC, August 1991), Table 34; and Federal Energy Regulatory Commission (FERC) Form 423, "Monthly Report of Cost and Quality of Fuels for Electric Plants."

helped Indiana coal producers retain a share of the utility market and preserve some of the 3,000 jobs (mining and other coal industry jobs) in the State. ${ }^{48}$

PublicService of Indiana's Gibson plant, the third largest coal-fired power plant in the United States, chose to scrub its No. 4 unit to comply with Title IV and received virtually all of its 1995 coal from Illinois (as it had in 1990). In fact, Indiana received almost the same quantity of coal

42 Alliance for Clean Coal vs. Bayh, Docket No. IT94-890-C-T/G. March 22, 1995. Appealed and affirmed December $22,1995$.

43 In a recent ruling, U.S. District Judge John Holschuk dismissed the Alliance for Clean Coal suit to overturn a 1991 Ohio coal law (Case No. C2-95-905) that gives regulatory and tax preferences to Ohio utilities that burn Ohio coal. Utility Environment Report, October 25, 1996, p. 2.

${ }^{44}$ Energy Information Administration, Coal Industry Annual 1995, DOE-EIA-0584 (Washington, DC, October 1996), Tables 1 and 40.

45 Energy Information Administration, Coal Industry Annual 1995, DOE/EIA-0584 (Washington, DC, October 1996 ), p. 7.

46 Energy Information Administration, State Coal Profiles, DOE-EIA-0576 (Washington, DC, January 1994), p. 31.

47 Indiana Business Magazine, Vol. 39, No. 2, February 1995, p. 186.

${ }^{48}$ Ibid. 
in 1995 as it did in 1990 (about 49 million tons); however, this coal had a significantly lower sulfur content (24 percent lower). From 1990 to 1995, in-state coal use was reduced by 5 million tons and coal from western Kentucky was reduced by 3 million tons. Indiana utilities increased their use of Wyoming coal by 6.3 million tons (Figure 10), and slightly increased their use of coal from Virginia, Illinois, and Ohio. In 1995, the number of mines in operation dropped from 64 in 1990 to 42 in 1995. Employment in the mines decreased on average by about 9 percent per year during this period.

\section{The States of Michigan and Missouri}

In 1990, Michigan received 30 million tons of coal and Missouri received 24 million tons; Michigan had one plant with 2 Table 1 units, while 8 Missouri plants had 16 Table 1 units. Both States received some coal from PRB in 1990;

\section{Figure 10. Origin of Coal Received in Indiana,} 1990 and 1995
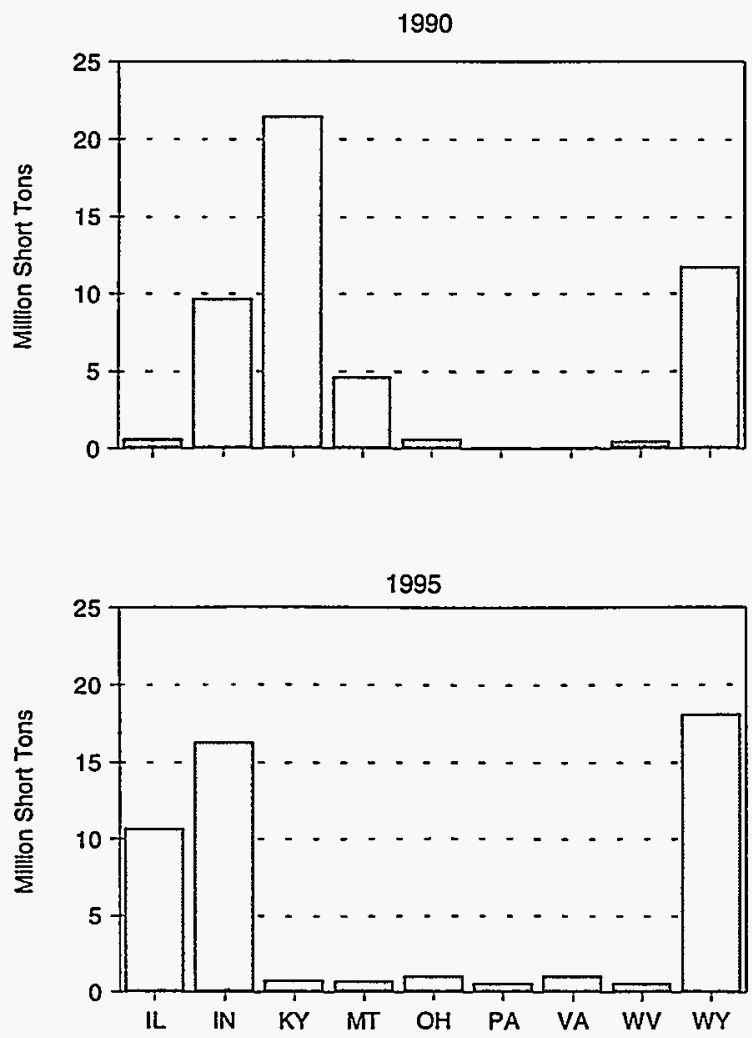

Sources: Energy Information Administration, Cost and Quality of Fuels for Electric Utility Plants 1990, DOE/EIA0191 (Washington, DC, August 1991), Table 34; and Federal Energy Regulatory Commission (FERC) Form 423, "Monthly Report on Cost and Quality of Fuels for Electric Plants."
Michigan combined PRB coal with 13 million tons of coal from the central Appalachian region, while Missouri combined PRB coal with 12 million tons from Mllinois.

In 1995, compliance programs in Missouri reduced Illinois coal usage by 8 million tons, a large portion of the 23percent decline in coal originating from Illinois between 1990 and 1995. Missouri increased its 1995 total receipts by 6.5 million tons from 1990 , purchasing 25.6 million tons from the PRB, and reduced its average sulfur content to 0.57 percent by weight, a 72 percent reduction in 1995 (Figure 11). Michigan replaced about 3 million tons of Central Appalachian coal with 3 million tons of Powder River Basin coal in the same period (Figure 12).

\section{The State of Ohio}

Ohio is part of the northern Appalachian coal production region, which also includes Pennsylvania, Maryland, and

\section{Figure 11. Origin of Coal Received in Missouri, 1990 and 1995}
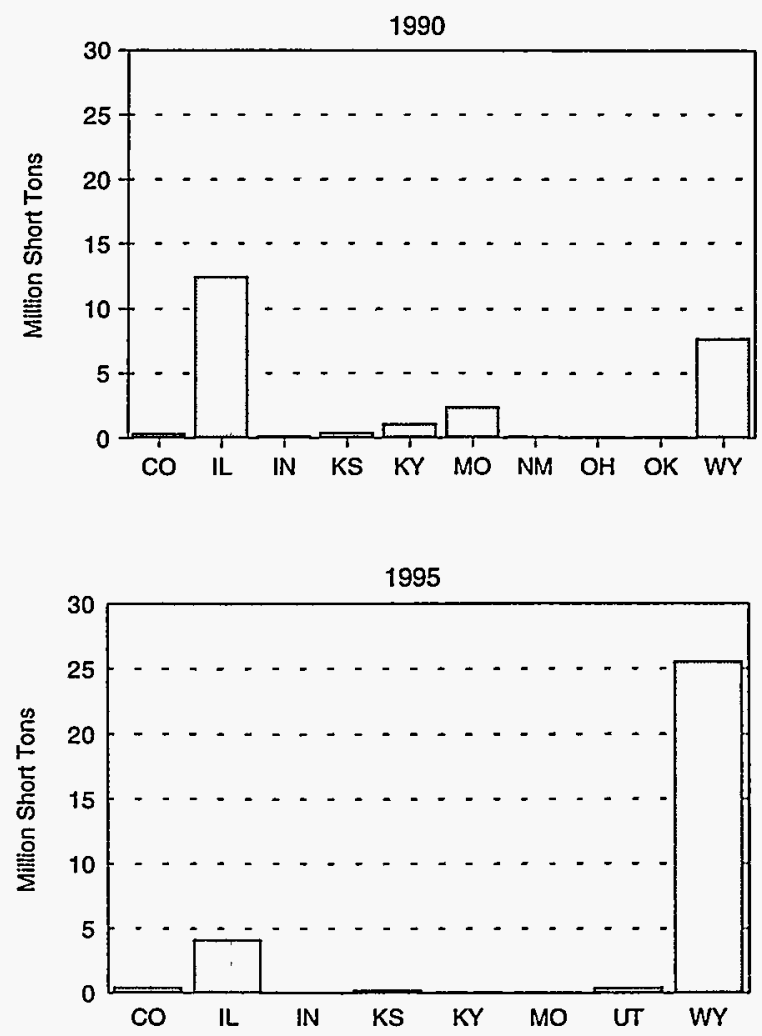

Sources: Energy Information Administration, Cost and Quality of Fuels for Electric Utility Plants 1990, DOE/EIA0191 (Washington, DC, August 1991), Table 34; and Federal Energy Regulatory Commission (FERC) Form 423, "Monthly Report of Cost and Quality of Fuels for Electric Plants." 
Figure 12. Origin of Coal Received in Michigan, 1990 and 1995
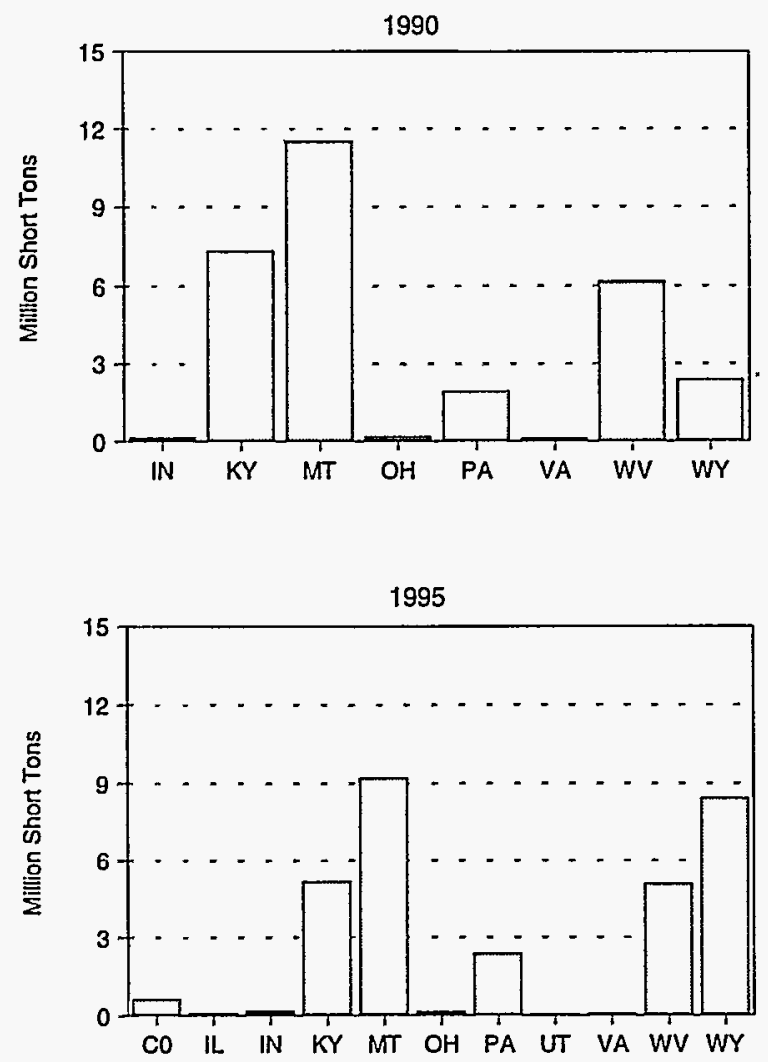

Sources: Energy Information Administration, Cost and Quality of Fuels for Electric Utility Plants 1990, DOE/EIA0191 (Washington, DC, August 1991), Table 34; and Federal Energy Regulatory Commission (FERC) Form 423, "Monthly Report of Cost and Quality of Fuels for Electric Plants."

the northern portion of West Virginia. Ohio coal is bituminous in rank and high in sulfur content (more than 3 percent by weight). In 1995, Ohio produced 26 million tons of coal, 9 million tons less than in 1990; 66 percent of the 1995 coal production was delivered to consumers in the State. Ohio is the third largest coal-consuming State after Texas and Indiana, and second in the Nation in the amount of electricity generated from coal in $1995 .^{49}$

Title IV targeted 14.3 gigawatts of Ohio's coal-fired capacity ( 57.3 percent) as Table 1 units, which translates to 41 units in 15 plants in the State. In early 1995, two wet limestone scrubbers went into commercial operation for Phase I compliance at the 2,600 MW Gavin plant of the Ohio Power Company, the largest coal-fired plant in Ohio..$^{50}$

This \$630-million-dollar project allowed the Gavin plant to continue using Ohio coal-5.8 million tons in 1995 compared to 6.4 million tons in 1990 . Ohio Edison's Niles plant used almost 100 percent Ohio coal in 1995 because of the operating success of a year-old, $\$ 31$ million LS-2 wet scrubber installed at generator No. 1, a 132.8 megawatt unit. Compliance strategies chosen for the remainder of the Table 1 units in the State include the following: 16 units switched to lower sulfur coal, 20 units used allowances, 1 unit was scrubbed, and 1 unit was retired.

Compliance with Phase I had some impact on Ohio's coal consumption. In 1995, Ohio received 48 million tons of coal, a decrease of about 4 million tons from the total receipts in 1990 and a decrease of 8 million tons of Ohio coal (Figure 13). An 8-million-ton increase of coal from central Appalachia supplemented Ohio receipts, resulting in a drop of the average sulfur content by weight from 2.44 in 1990 to 1.89 in 1995. The number of mines operating in Ohio in 1990 was 172, decreasing to 113 in 1995 , while the number of miners decreased on average by 10 percent per year during this period.

\section{The Northeast Demand Region}

The Northeast demand region is made up of the Middle Atlantic and New England census divisions, which include Connecticut, Maine, Massachusetts, New Hampshire, New York, New Jersey, Pennsylvania, Rhode Island, and Vermont (Figure 8). In 1995, this region received 54 million tons of coal, with more than 70 percent $(38$ million tons) received by Pennsylvania. In this region, 35 units at 16 plants were designated as Table 1 units. Pennsylvania had the most, 21 units at 9 plants.

\section{The Commonwealth of Pennsylvania}

Pennsylvania has long been a major producer and consumer of coal and led the Nation in coal production until the early 1950's. ${ }^{51}$ In 1995, Pennsylvania produced 62 million tons of coal; approximately 47 percent

\footnotetext{
49 Energy Information Administration, Electric Power Annual 1995 Volume I, DOE/EIA-0384 (Washington, DC, July 1995).

50 "Western Coal Suppliers, Railroads Sue to Overturn Ohio Coal Protection" Law, Electric Utility Week, September 25, 1995, p. 77.

${ }^{51}$ Energy Information Administration, State Coal Profiles, DOE/ELA-0576 (Washington, DC, January 1994).
} 
Figure 13. Origin of Coal Received in Ohio, 1990 and 1995
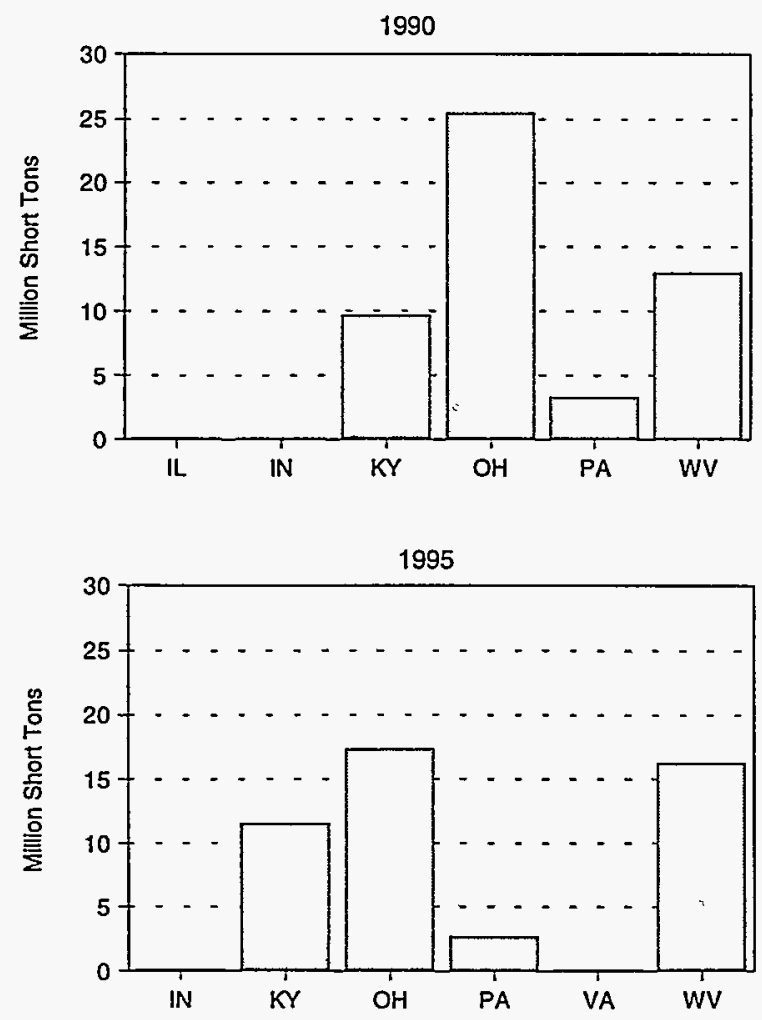

Sources: Energy Information Administration, Cost and Quality of Fuels for Electric Utility Plants 1990, DOE/EIA0191 (Washington, DC, August 1991), Table 34; and Federal Energy Regulatory Commission (FERC) Form 423, "Monthly Report of Cost and Quality of Fuels for Electric Plants."

remained in the State. ${ }^{52}$ The largest out-of-state shipments went to New York, Ohin, and Michigan.

Pennsylvania is part of the northern Appalachian coalproducing region, an area that has seen a decline in shipments to electric utilities in recent years. From 1990 to 1995, Pennsylvania reduced its total coal receipts by 6.3 million tons, with almost all of this decline occurring in the central Pennsylvania coal production area (in Clearfield, Jefferson, Indiana, Cambria, Clarion, and Somerset counties) (Figure 14). These counties are part of the U.S. Bureau of Mines District 1 (BOM 1), a region populated by small to mid-size producers facing a depleting reserve base, escalating mining costs and shrinking demand..$^{53}$ One large regional coal producer, Rochester \& Pittsburgh, closed two of its Helvetia mines in 1994 and three highcost Keystone mines in December $1995 .^{54}$

In 1990, PP\&L, a utility with three of its four coal-fired plants targeted for Phase I reductions, purchased over 90 percent of its coal from central Pennsylvania. By 1995, PP\&L receipts from central Pennsylvania had fallen to 43 percent of its total receipts. This utility substituted 80

Figure 14. Origin of Coal Received in Pennsylvania, 1990 and 1995
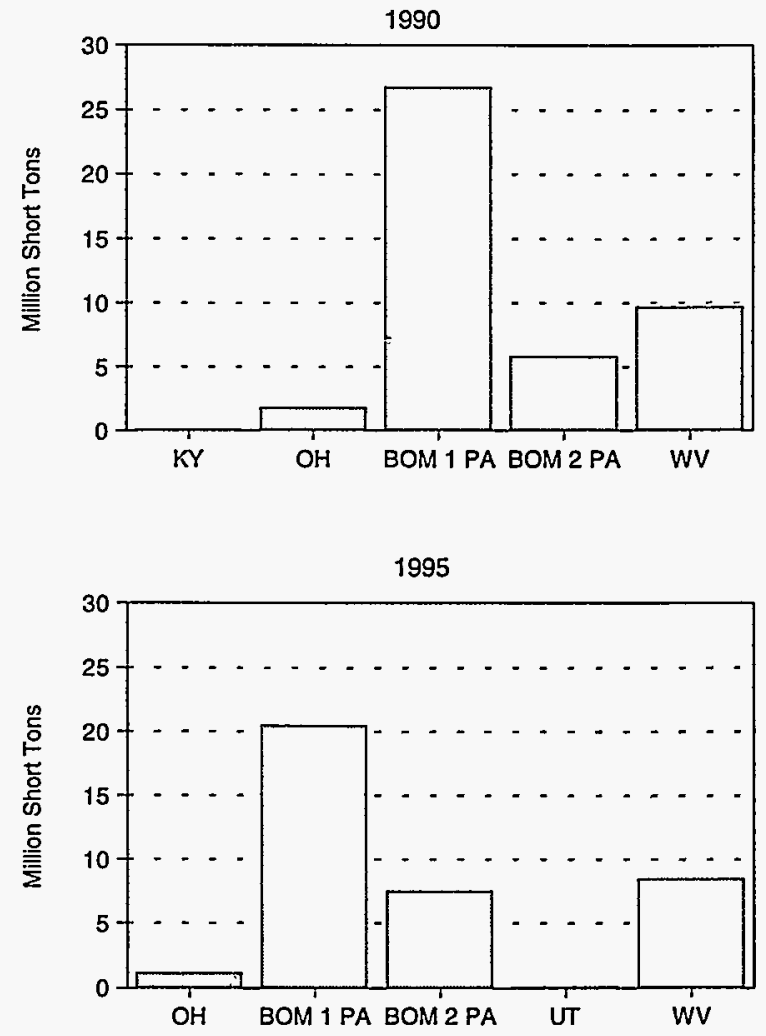

BOM 1 PA = Bureau of Mines District 1, Pennsylvania. BOM 2 PA = Bureau of Mines District 2, Pennsylvania. Note: See glossary for specific counties in BOM Districts 1 and 2 in Pennsylvania.

Sources: Energy Information Administration, Cost and Quality of Fuels for Electric Utility Plants 1990, DOE/EIA-0191 (Washington, DC, August 1991), Table 34; and Federal Energy Regulatory Commission (FERC) Form 423, "Monthly Report of Cost and Quality of Fuels for Electric Plants."

\footnotetext{
52 Energy Information Administration, Coal Industry Annual 1995, DOE/ELA-0584(95) (Washington, DC, October 1996).

53 "Central Pennsylvania Coal Faces an Uncertain Future," Coal, March 1996, p. 37.

54 Ibid.
} 
percent of its Brunner Island plant purchases and 50 percent of its Martins Creek plant purchases with lower sulfur coal supplies from Pittsburgh No. 8 seam in Greene County (BOM District 2) (Figure 14). ${ }^{55}$ Utilities in the State of New York reduced total coal purchases by almost 3 million tons in 1995; almost all of the decline was in the central Pennsylvania area (Figure 15). More than twothirds of the coal produced in Pennsylvania comes from underground mines. The number of miners has dropped by 6,935 since 1990 . The number of mines operating in Pennsylvania was 459 in 1995, a drop of 32 percent since 1990.

\section{The South Demand Region}

The broad South demand region encompasses three census divisions: the South Atlantic census division (Delaware, District of Columbia, Florida, Georgia, Maryland, North Carolina, South Carolina, Virginia, and West Virginia); the East South Central census division (Alabama, Kentucky, Mississippi, and Tennessee); and the West South Central census division (Arkansas, Louisiana, Oklahoma, and Texas). Transportation to utilities in the South region is dominated by long-distance rail hauls from Appalachian and, more recently, western mines. ${ }^{56}$ As the distance that contract coal was shipped by rail increased and rail costs decreased slightly, more contract coal was shipped by rail to utilities in the South than in any other region in 1993.

Ninety-two generating units at 33 plants were designated as Table 1 units in the South region. Tennessee and Georgia had 19 Table 1 units each, followed by Kentucky with 17 units, West Virginia with 14, and Alabama with 10 Table 1 units. Florida, Maryland, and Mississippi had a total of 13 Table 1 units. Texas, the largest consumer of coal at electric utility plants in the United States, had no Table 1 units.

In 1995, six States dominated the coal purchases at electric utilities: Kentucky purchased 37 million tons, West Virginia purchased 30 million tons, Georgia and Alabama each purchased 28 million tons, Florida purchased 24 million tons, and Tennessee purchased 24 million tons. Of the six States, Georgia, West Virginia, and Tennessee had the highest $1985 \mathrm{SO}_{2}$ emissions in the South region.
Figure 15. Origin of Coal Received in New York, 1990 and 1995
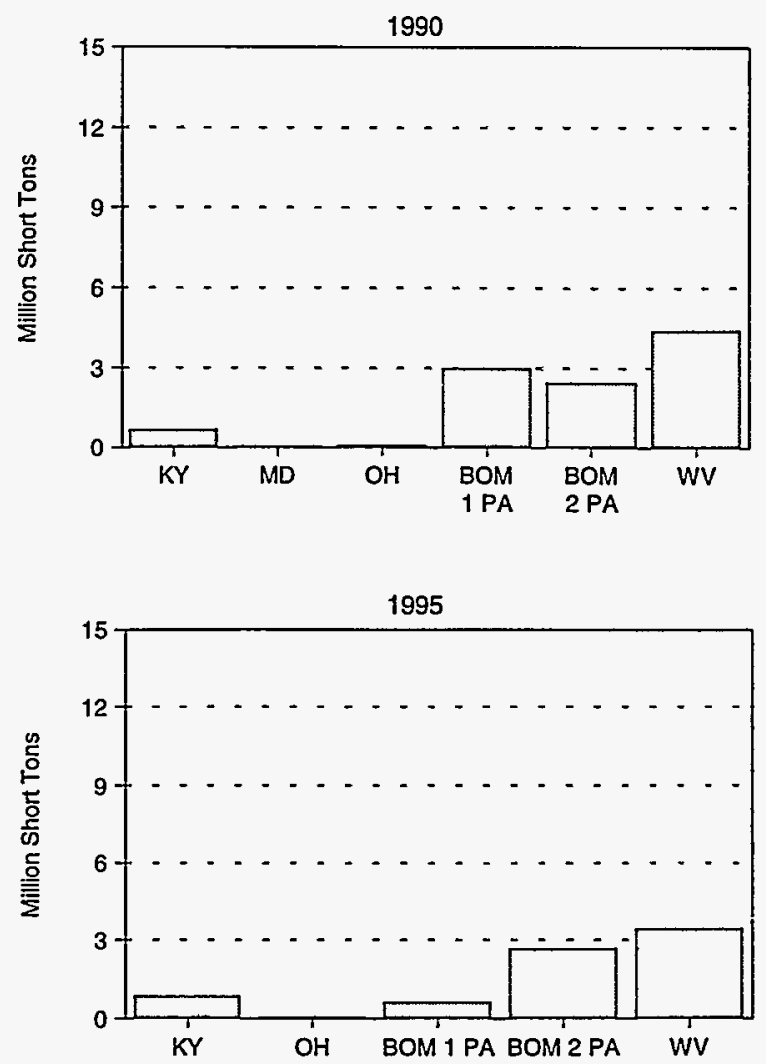

$B O M 1 P A=$ Bureau of Mines District 1, Pennsylvania. BOM 2 PA = Bureau of Mines District 2, Pennsylvania. Note: See glossary for specific counties in BOM Districts 1 and 2 in Pennsylvania.

Sources: Energy information Administration, Cost and Quality of Fuels for Electric Utility Plants 1990, DOE/EIA0191 (Washington, DC, August 1991), Table 34; and Federal Energy Regulatory Commission (FERC) Form 423, "Monthly Report of Cost and Quality of Fuels for Electric Plants."

\section{The State of West Virginia}

West Virginia has abundant bituminous coal resources underlying more than two-thirds of the State. The coal deposits are divided geologically into the northern and southern fields. Coalbeds in the southern field generally have a higher heating value and a lower sulfur content than the northern field. ${ }^{57}$ With well-established railroad

\footnotetext{
55 Ibid.

${ }^{56}$ Energy Information Administration, EPACT Transportation Rate Study: Interim Report on Coal Transportation, DOE/EIA-0597 (Washington, DC, October 1995), p. 61.

${ }^{57}$ Energy Information Administration, State Coal Profiles, DOE/EIA-0576 (Washington, DC, January 1994), p. 103.
} 
and river transportation facilities, coal production in the State was 163 million tons in 1995 . Most of the coal produced is shipped outside the State. ${ }^{58}$

The 13 coal-fired electric utility plants in West Virginia received approximately 30 million tons of coal in 1995; about 86 percent came from within the State. Fourteen units at six West Virginia plants were designated as Table 1 units. Monongahela Power and Virginia Electric \& Power installed scrubbers at two plants to comply, thus earning allowance credits for five units at three plants. Ohio Power used lower sulfur coal at two Table 1 units and allowances at three Table 1 units.

Northern West Virginia, a higher sulfur coal producing area, may have been affected by these compliance strategies because the State decreased its use of coal from northern West Virginia by about 2 million tons between 1990 and 1995 (Figure 16). The compliance programs of its other customers had greater impact on northern West Virginia, which is part of the hard-hit northern Appalachian region. The number of operating mines in northern West Virginia declined from 205 in 1990 to 98 in 1995, and the number of miners working in the mines fell on average by 9 percent per year during this period.

Between 1990 and 1995, the southern West Virginia lower sulfur coal producing area experienced little impact from the implementation of Phase I from its in-state customers because these electric utilities maintained the same level of in-state coal usage in 1995 as in 1990 (approximately 11 million tons). Total receipts originating from southern West Virginia increased substantially because out-of-state customers purchased more lower sulfur coal in 1995. Although coal production from southern West Virginia increased by 4 million short tons between 1990 and 1995, the number of operating mines decreased from 566 to 326, and the number of miners working in southern West Virginia decreased from 19,525 to 15,220 during this period. ${ }^{59}$ A number of small high cost mines in the region are marginal producers and typically shutdown when the price of coal is low and operate when prices are higher. Between 1990 and 1995, the average delivered price of low sulfur coal from southern West Virginia declined by $\$ 10$ per short ton.
Figure 16. Origin of Coal Received in West Virginia, 1990 and 1995
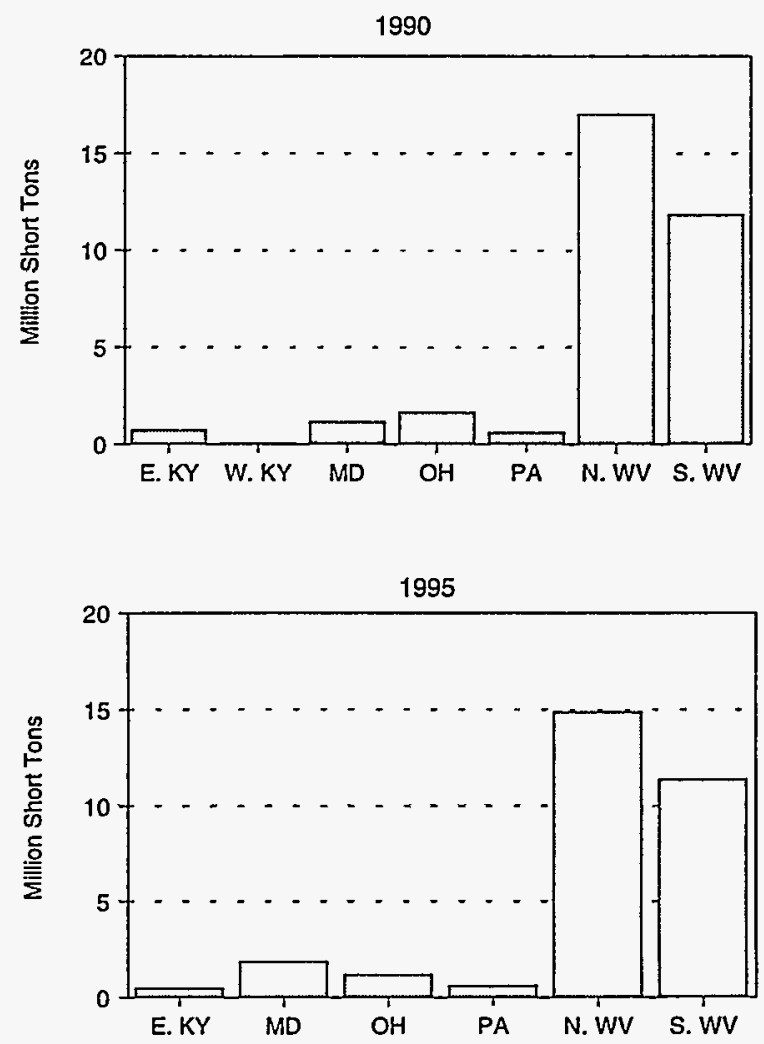

Sources: Energy Information Administration, Cost and Quality of Fuels for Electric Utility Plants 1990, DOE/EIA0191 (Washington, DC, August 1991), Table 34; and Federal Energy Regulatory Commission (FERC) Form 423, "Monthly Report of Cost and Quality of Fuels for Electric Plants."

\section{The Commonwealth of Kentucky}

With production of 154 million tons in 1995, Kentucky is one of the major coal-producing States, third largest after Wyoming and West Virginia. Kentucky coal deposits consist of bituminous coal in two coalfields, one in the east and the other in the west. The eastern coalfield is part of the Appalachian coal basin where the coal has a heat content of about 26 million Btu per short ton and a sulfur content of 1 to 2 percent by weight. The heat content of

\footnotetext{
58 Ibid.

59 Energy Information Administration, Coal Industry Annual 1994 and Coal Industry Annual 1995, DOE/EIA-0584(94) and (95) (Washington, DC, October 1994 and 1995).
} 
the coal in the western field, which is a continuation of the Illinois basin, is slightly lower, but the sulfur content is higher (approximately 3 to 4 percent by weight). ${ }^{60}$

Electric utilities in Kentucky purchased 37 million tons of coal in 1995, almost 2 million tons more than were purchased in 1990. Seventeen units at 10 utilities were designated as Table 1 units. Phase I compliance programs resulted in a mixed impact on coal sales from Kentucky. Eastern Kentucky, the lower sulfur coal producing area, maintained the same level of coal sales within the State at 9 million tons in 1990 and 1995 (Figure 17). Eastern Kentucky also increased its total coal shipments to electric utilities but there was a shift from high to low and medium sulfur coal. However, total coal production declined by 10 million short tons. The operating mines in eastern Kentucky decreased from 902 to 540 and the number of miners decreased by 8,000 , to 16,840 . Western Kentucky's in-state coal sales were reduced by 1 million tons, having been replaced by coal from Colorado. The number of operating mines in western Kentucky was reduced from 85 in 1990 to 58 in 1995, and the number of miners fell from 5,586 in 1990 to 4,285 in 1995 (Table 12).

Of the 17 Table 1 units in Kentucky, five were retrofitted with scrubbers, 7 switched to lower sulfur coal, and 5 units were designated as using allowances. The average sulfur content of the coal received in Kentucky was reduced from 2.59 percent by weight in 1990 to 2.42 percent by weight in 1995.

\section{The States of Georgia and Tennessee}

Two other southern States of interest in the Title IV program are Georgia and Tennessee because they each had 19 units designated in Table 1 . Georgia emitted 815,000 tons of $\mathrm{SO}_{2}$ in 1985 and 638,000 tons were emitted in Tennessee. Although these States are not important coal-producing States (Tennessee produced 3 million tons in 1995 and Georgia produced none), their compliance strategies affected coal sales in other States.

Georgia purchased almost the same amount of coal in 1995 as it did in 1990, approximately 28 million tons. However, in 1995 its lower sulfur coal purchases from the central Appalachian and PRB regions increased by 8 million tons, while its higher- and medium-sulfur coal purchases fell by 8 million tons, with a 4-million ton reduction in purchases from Illinois (Figure 18). Of the 19 Table 1 units, all owned and operated by Georgia Power,
Figure 17. Origin of Coal Received in Kentucky, 1990 and 1995
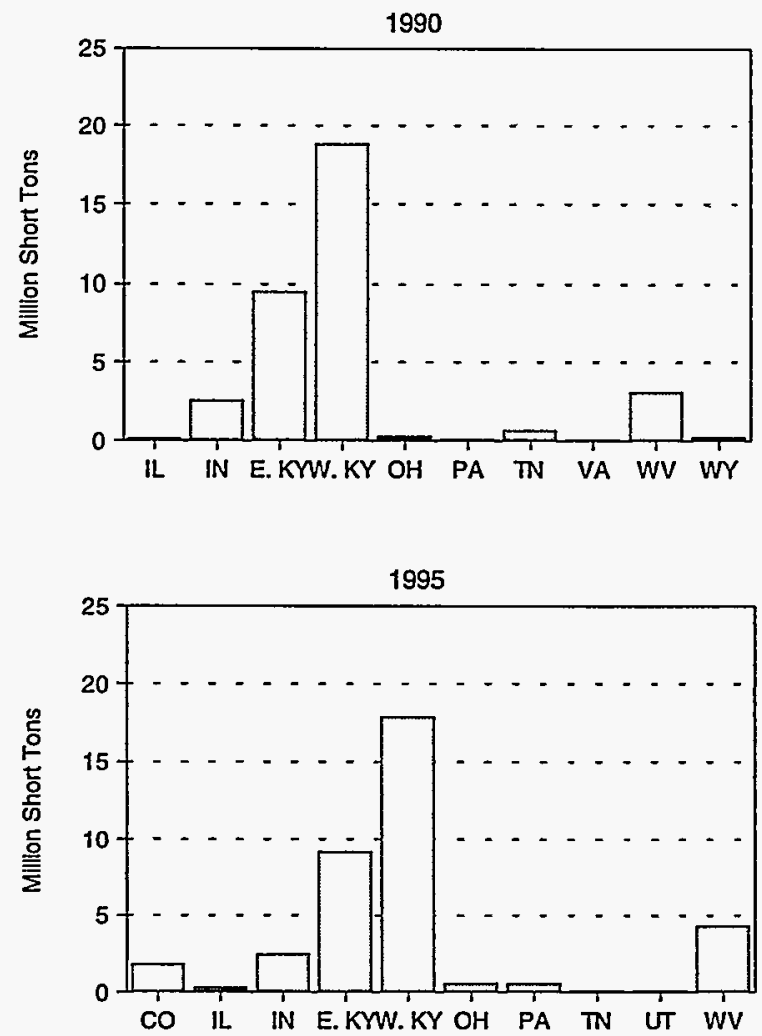

Sources: Energy Information Administration, Cost and Quality of Fuels for Electric Utility Plants 1990, DOE/EIA0191 (Washington, DC, August 1991), Table 34; and Federal Energy Regulatory Commission (FERC) Form 423, "Monthly Report of Cost and Quality of Fuels for Electric Plants."

18 were switched to lower sulfur coal and one unit at the Yates plant was retrofitted with a scrubber.

In Tennessee, the total coal receipts for the State rose by almost 3 million tons between 1990 and 1995, but no significant source changes were made during that period. Lower sulfur coal receipts from Utah and higher sulfur coal receipts from Illinois increased by more than a million each (Figure 19). The average sulfur content of Tennessee's 1995 coal receipts decreased slightly from 2.00 in 1990 to 1.97 in 1995. All of the 19 Table 1 units in Tennessee are operated by the Tennessee Valley Authority (TVA). TVA designated the use of allowances as the compliance strategy for 14 units, retrofitted 2 units with scrubbers and used lower sulfur coal for 3 units.

${ }^{60}$ Energy Information Administration, State Coal Profiles, DOE/EIA-0576 (Washington, DC, January 1994). 
Table 12. The Number of Mines and the Average Number of Miners Working Daily by State for 1990 and 1995

\begin{tabular}{|c|c|c|c|c|}
\hline \multirow[b]{2}{*}{ State } & \multicolumn{2}{|c|}{1990} & \multicolumn{2}{|c|}{1995} \\
\hline & Mines $^{a}$ & Miners $^{b}$ & Mines $^{a}$ & Miners $^{b}$ \\
\hline Alabama $\ldots \ldots \ldots \ldots \ldots \ldots \ldots$ & 97 & 6,534 & 73 & 5,567 \\
\hline Alaska $\ldots \ldots \ldots \ldots \ldots \ldots$ & 1 & 84 & 1 & 102 \\
\hline 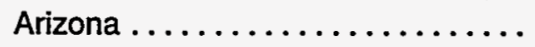 & 2 & 951 & 2 & 831 \\
\hline Arkansas $\ldots \ldots \ldots \ldots \ldots \ldots \ldots$ & 7 & 13 & 3 & 4 \\
\hline California.$\ldots \ldots \ldots \ldots \ldots \ldots$ & 1 & 5 & & \\
\hline Colorado $\ldots \ldots \ldots \ldots \ldots \ldots \ldots$ & 23 & 2,009 & 17 & 1,777 \\
\hline \multicolumn{5}{|l|}{ Georgia $\ldots \ldots \ldots \ldots \ldots \ldots$. } \\
\hline Illinois $\ldots \ldots \ldots \ldots \ldots \ldots \ldots \ldots$. & 45 & 10,018 & 31 & 5,652 \\
\hline Indiana $\ldots \ldots \ldots \ldots \ldots \ldots \ldots$ & 64 & 4,195 & 42 & 2,571 \\
\hline lowa $\ldots \ldots \ldots \ldots \ldots \ldots \ldots \ldots$ & 3 & 135 & & \\
\hline Kansas $\ldots \ldots \ldots \ldots \ldots \ldots \ldots$ & 4 & 132 & 1 & 54 \\
\hline \multicolumn{5}{|l|}{ Kentucky } \\
\hline Eastern $\ldots \ldots \ldots \ldots \ldots \ldots$ & 902 & 24,912 & 540 & 16,840 \\
\hline Western ................ & 85 & 5,586 & 58 & 4,285 \\
\hline Louisiana . . . . . . . . . . . . & 2 & 103 & 2 & 114 \\
\hline Maryland $\ldots \ldots \ldots \ldots \ldots \ldots$ & 27 & 589 & 20 & 458 \\
\hline Missouri $\ldots \ldots \ldots \ldots \ldots \ldots \ldots$ & 5 & 347 & 6 & 92 \\
\hline 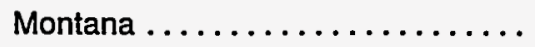 & 9 & 821 & 8 & 722 \\
\hline New Mexico . . . . . . . . . . . . . & 7 & 1,472 & 7 & 1,747 \\
\hline North Dakota . . . . . . . . . . . . & 11 & 931 & 6 & 716 \\
\hline Ohio $\ldots \ldots \ldots \ldots \ldots \ldots \ldots \ldots$ & 172 & 5,866 & 113 & 3,386 \\
\hline Oklahoma $\ldots \ldots \ldots \ldots \ldots \ldots$ & 23 & 415 & 13 & 241 \\
\hline \multicolumn{5}{|l|}{ Pennsylvania } \\
\hline Anthracite $\ldots \ldots \ldots \ldots \ldots \ldots$ & 187 & 1,687 & 134 & 1,069 \\
\hline Bituminous $\ldots \ldots \ldots \ldots \ldots \ldots$ & 486 & 14,216 & 325 & 7,899 \\
\hline Tennessee . . . . . . . . . . . . . & 86 & 1,697 & 25 & 681 \\
\hline 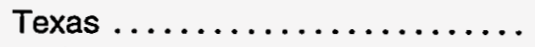 & 15 & 2,131 & 14 & 1,590 \\
\hline Utah $\ldots \ldots \ldots \ldots \ldots \ldots \ldots$ & 18 & 2,434 & 13 & 1,893 \\
\hline Virginia $\ldots \ldots \ldots \ldots \ldots \ldots \ldots$ & 340 & 10,342 & 194 & 6,919 \\
\hline Washington $\ldots \ldots \ldots \ldots \ldots$ & 4 & 777 & 3 & 566 \\
\hline \multicolumn{5}{|l|}{ West Virginia } \\
\hline Northern $\ldots \ldots \ldots \ldots \ldots \ldots$ & 205 & 10,053 & 98 & 6,114 \\
\hline Southern..$\ldots \ldots \ldots \ldots \ldots$ & 566 & 19,525 & 326 & 15,220 \\
\hline Wyoming $\ldots \ldots \ldots \ldots \ldots \ldots$ & 33 & 3,330 & 29 & 3,142 \\
\hline U.S. Total $\ldots \ldots \ldots \ldots \ldots \ldots$ & 3,430 & 131,310 & 2,104 & 90,252 \\
\hline
\end{tabular}

aExcludes silt, culm, refuse bank, slurry dam, and dredge operations, except for Pennsylvania anthracite.

bincludes all employees engaged in production, preparation, processing, development, maintenance, repair, and shop or yard work at mining operations; includes mining operations management and all technical and engineering personnel; and excludes office workers. The average number of miners working daily is the arithmetic mean number of miners working each day at a mining operation.

Sources: Energy Information Administration, Coal Industry Annual 1994, DOE/EIA-0584 (Washington, DC, October 1995), Tables 2 and 39; and Coal Industry Annual 1995, DOE/EIA-0584 (Washington, DC, October 1996), Tables 2 and 40.

\section{The West Demand Region}

The West demand region includes the Mountain and Pacific census divisions (Arizona, Colorado, Montana, Nevada, New Mexico, Utah, Wyoming, Oregon, and Washington). This region received 108 million tons of coal in 1995. Contract coal delivered to the region was transported by rail, truck, conveyor, slurry pipeline, and a combination of modes. The West demand region had no Table 1 units because the coal burned in this region is lower sulfur coal resulting in low $\mathrm{SO}_{2}$ emissions. Wyoming and Utah, however, each have units that were designated as substitution units. The West demand region is an integral part of the Title IV compliance 
Figure 18. Origin of Coal Received in Georgia, 1990 and 1995
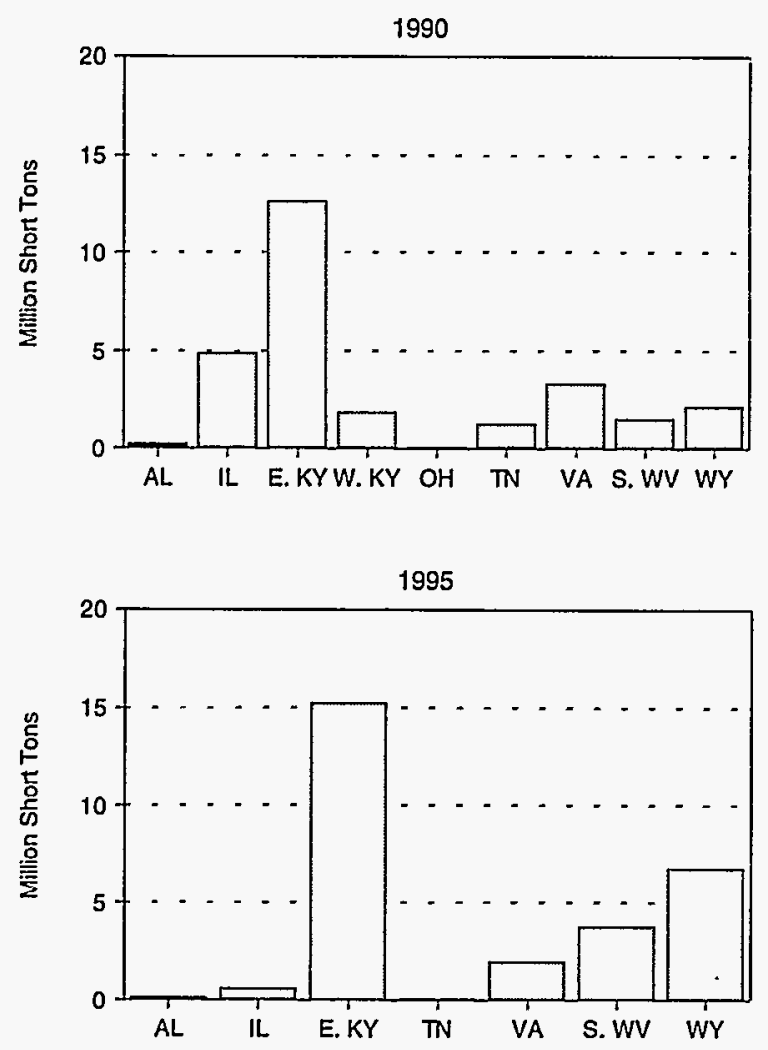

Sources: Energy Information Administration, Cost and Quality of Fuels for Electric Utility Plants 1990, DOE/EIA0191 (Washington, DC, August 1991), Table 34; and Federal Energy Regulatory Commission (FERC) Form 423, "Monthly Report of Cost and Quality of Fuels for Electric Plants."

program because it has become the major supplier of lower sulfur coal to utilities in the Midwest and South demand regions. Central to this growth share by the West demand region is the low delivered price of western coal. Between 1991 and 1995, the average mine price of
Figure 19. Origin of Coal Received in Tennessee, 1990 and 1995
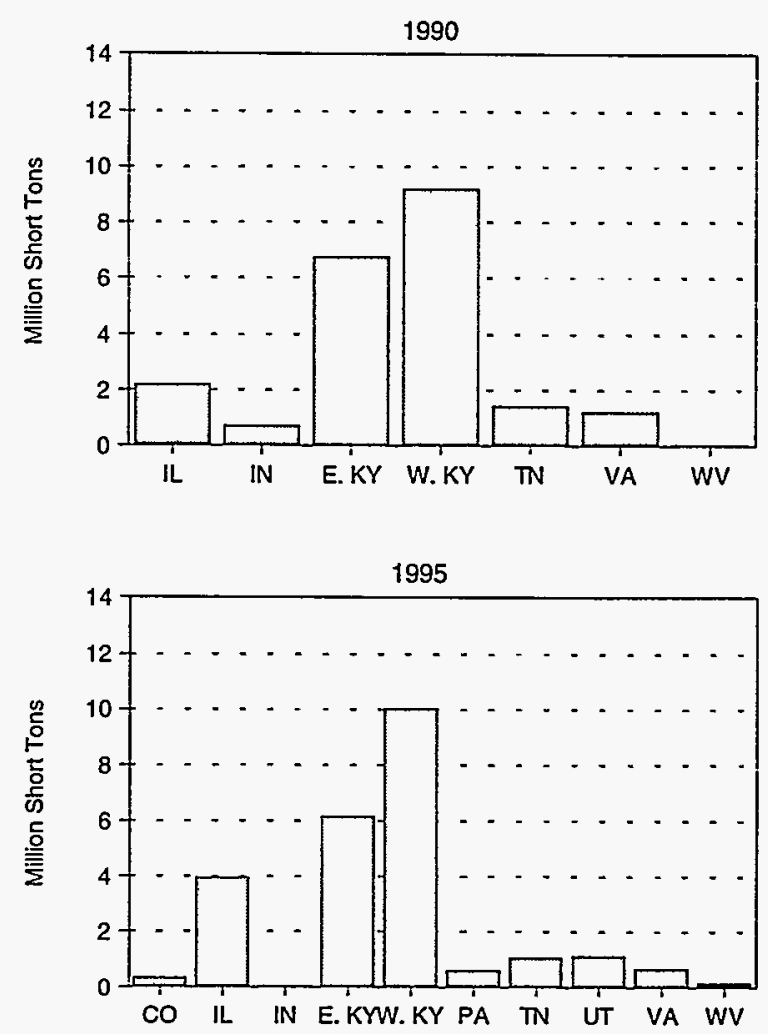

Sources: Energy Information Administration, Cost and Quality of Fuels for Electric Utility Plants 1990, DOE/EIA0191 (Washington, DC, August 1991), Table 34; and Federal Energy Regulatory Commission (FERC) Form 423, "Monthly Report of Cost and Quality of Fuels for Electric Plants."

Wyoming coal fell 5 percent per year to $\$ 6.58$ per ton in 1995, ${ }^{61}$ and rail transportation rates for contract coal originating in Wyoming, Colorado, Utah, and Montana decreased by more than 20 percent between 1988 and $1993 .{ }^{62}$

61 Energy Information Administration, Coal Industry Annual 1995, DOE/EIA-0584 (Washington, DC, October 1996 ), Table 80.

${ }^{62}$ Energy Information Administration, EPACT Transportation Rate Study: Interim Report on Coal Transportation, DOE/EIA-0597 (Washington, DC, October 1995), pp. 32-33. 


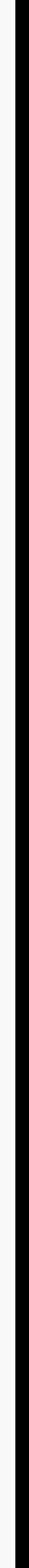




\section{Developments Since Phase I Took Effect}

Since Phase I began on January 1,1995 , some developments have been noteworthy. First, the U.S. Environmental Protection Agency's (EPA's) initial rule for a group of Phase I boilers' nitrogen oxides $\left(\mathrm{NO}_{x}\right)$ reductions was vacated by a U.S. Court of Appeals; EPA subsequently reissued the rule for these boilers. A rule for other Phase I and Phase II boilers has been issued. Second, the regulation of air toxics are unclear at this time. Third, significant developments have been made in air pollution control technology. This chapter summarizes these latest developments.

\section{Programs for the Control of Nitrogen Oxides Emissions}

\section{Original Rule for Phase I, Group 1 Boilers}

Title IV of the Clean Air Act Amendments of 1990 (CAAA90) calls for EPA to establish regulations for the reduction of $\mathrm{NO}_{x}$ emissions from coal-fired utility boilers in two stages. In the first stage, two categories of boilers affected by Phase I of the sulfur dioxide $\left(\mathrm{SO}_{2}\right)$ program are covered: tangentially fired boilers and dry bottom wall-fired boilers (Group 1). "Dry-bottom" refers to the form of the ash that leaves the boiler. In dry-bottom boilers, the temperature remains below the ash melting point, and the ash remains in a solid, "dry" form. Another type of boiler, called a wet-bottom boiler, gets hot enough to melt the ash before it leaves the boiler. "Wall-fired" and "tangentially fired" refer to the placement and orientation of burners in the combustion chamber. The burners of wall-fired boilers are perpendicular to the wall of the chamber, either all on one wall (front) or split between two facing walls (opposed). Tangentially fired burners are spaced around the chamber and angled to produce a rotating flame within the chamber. ${ }^{63}$ CAAA90 instructs EPA to set less rigid standards if it finds that the legislated limits cannot be achieved using low- $\mathrm{NO}_{x}$ burner technology ${ }^{64}$ The legislation specifies the maximum allowable emission rates for Group 1 boilers as 0.45 pounds of $\mathrm{NO}_{\mathrm{x}} / \mathrm{mmBtu}$ for tangentially fired boilers and as 0.50 pounds $/ \mathrm{mmBtu}$ for dry-bottom, wall-fired boilers (other than units applying cell-burner technology). About one-quarter of all Group 1 boilers are covered in Phase I of the $\mathrm{SO}_{2}$ program. ${ }^{65}$

\section{Final Rule for Phase I, Group 1 Boilers}

On March 22, 1994, EPA promulgated a rule establishing the Phase I Group $1 \mathrm{NO}_{x}$ emissions reduction program. ${ }^{66}$ However, on November 29, 1994, after a challenge from utility groups, the U.S. Court of Appeals for the District of Columbia Circuit found that the definition of low- $\mathrm{NO}_{x}-$ burner technology contained in the March 22 rule exceeded EPA's statutory authority. The Court vacated the rule and sent it back to EPA. On March 28, 1995, EPA signed an agreement with environmental and utilityindustry parties that addressed the March 22, 1994, regulations and the issues raised by the Court's remand, ${ }^{67}$ and on April 13,1995, ${ }^{68}$ it issued a final rule revising the definition of low-NO $\mathrm{NO}_{\mathrm{x}}$-burner technology.

The final rule removed a requirement that wall-fired and tangentially fired boilers must use an over-fire air process to be eligible for the previously mentioned less stringent emissions controls. The rule also extended the date for complying with the first stage from January 1, 1995, to January 1,1996 . EPA estimates that the final Phase I rule will cut annual emissions of $\mathrm{NO}_{\mathrm{x}}$ from Phase I, Group 1 boilers by 400,000 tons beginning in 1996.

63 Energy Information Administration, Electric Utility Phase I Acid Rain Compliance Strategies for the Clean Air Act Amendments of 1990, DOE/EIA-0582 (Washington, DC, March 1994), p. 99.

64 Clean Air Act, Section 407 (b) (1).

65 Environmental Protection Agency, EPA Fact Sheet: Nitrogen Oxides Emission Reduction Program, EPA430/F-92/014 (Washington, DC, October 1992).

66 Federal Register 40 CFR Part 76.

67 Ibid.

68 U.S. Environmental Protection Agency, EPA Fact Sheet, Nitrogen Oxides Emission Reduction Program: Proposed Rule for Phase II, Group 1 and Group 2 Boilers, EPA Number (http://www.epa.gov/docs/acidrain/noxfs2.html). 


\section{Rule for Phase II, Group 1 Boilers and for Group 2 Boilers}

On December 19, 1996, EPA issued a rule to implement the second stage of the $\mathrm{NO}_{x}$ reduction program by establishing $\mathrm{NO}_{\mathrm{x}}$ emissions limitations for additional coal-fired boiler units and by revising $\mathrm{NO}_{x}$ emissions limitations for Group 1 boilers. EPA's charge for the second stage of the $\mathrm{NO}_{x}$ program was twofold: (1) to determine whether the technology existed that would make it feasible for EPA to establish more stringent standards in Phase II for the Group 1 boilers than those established in Phase I; and (2) to establish limitations for the boilers known as Group 2 (boilers applying cell-burner technology, cyclone boilers, wet-bottom boilers, and other types of coal-fired boilers) based on $\mathrm{NO}_{\mathrm{x}}$ control technologies that are comparable in cost to low- $\mathrm{NO}_{\mathrm{x}}$ burners.

According to EPA, the total Group 1 reductions beginning in 2000 will be approximately 1.2 million tons. The total cost of this regulation to the industry is estimated to be $\$ 267$ million per year, resulting in an overall cost of $\$ 227$ per ton of $\mathrm{NO}_{x}$ removed. Group 2 reductions beginning in 2000 are estimated to be 890,000 tons annually. The annual cost of the Group 2 regulations is estimated to be approximately $\$ 200$ million with an average cost of $\$ 229$ per ton of $\mathrm{NO}_{\mathrm{x}}$ removed. ${ }^{69}$

\section{Toughèning of Phase II, Group I Boiler Limitations Based on Modeling}

From the results of two analyses, EPA concluded that data currently available on the effectiveness of low- $\mathrm{NO}_{x}$ burner technology supported revisions of the annual limitations for both dry-bottom, wall-fired boilers and tangentially fired boilers under the second stage of the $\mathrm{NO}_{x}$ program. EPA projects that 85 percent to 90 percent of the uncontrolled bottom wall-fired boilers and tangentially fired boilers could individually meet the proposed standards.

The $\mathrm{NO}_{\mathrm{x}}$ emission limitations for each boiler type follow in Table 13.
A. utility can choose to comply with the rule in one of three ways:

1. Meet the standard annual emission limitations

2. Average the emissions rates of two or more boilers (This allows utilities to "over-control" the emissions of those units that can be controlled more easily and less expensively than others.)

3. Apply for a less stringent alternative emissions limit if the utility cannot meet the standard emissions limit if it uses the applicable $\mathrm{NO}_{\mathrm{x}}$ emission control technology.

EPA's determination of an alternative emissions limitation will be based on evidence that control equipment was properly designed, installed, and operated during a demonstration period.

Phase II, Group 1 and Group 2 boilers are required to meet applicable limits by 2000. The highlight of the new rule is that, although it relies upon target performance standards, it also allows for emissions averaging and the use of alternative, higher emissions limits where meeting the applicable limits is not feasible. Utilities choose the method of compliance that best suits their needs. EPA states that this approach provides flexibility, promotes technology development and competition, and provides opportunities to reduce the cost of control. ${ }^{70}$ However, some industry groups state that the new rule "will impose unreasonable burdens on up to 1,000 coal-fired units. ${ }^{171}$

EPA has also devised an option whereby a state or group of states could petition EPA to accept an emissions cap and trade program under authority of Title I as a substitute for compliance with the final Title IV rule. Under such an option, EPA retains the authority to allow boilers subject to the final rule to achieve emissions reductions under a Title I cap and trade program as long as capping and trading would achieve lower emissions than the final rule. Existing limits for Phase I, Group 1 boilers would remain in effect. EPA believes that such a trading

69 Ibid.

70 Ibid.

71 Mining Week, National Mining Association, Issue 48, Vol. 2, Washington, DC, December 23, 1996, p. 2. 


\begin{tabular}{|c|c|c|}
\hline Boiler Types & Number of Boilers & $\begin{array}{l}\text { Proposed Phase II NO } \\
\text { Emissions Limits } \\
\text { (Pounds/mmBtu) }\end{array}$ \\
\hline \multicolumn{3}{|l|}{ Phase II, Group 1} \\
\hline Dry-Bottom, Wall-Fired..$\ldots \ldots \ldots \ldots \ldots \ldots \ldots$ & 308 & 0.46 \\
\hline$\ldots \ldots \ldots, \ldots, \ldots, \ldots, \ldots, \ldots$ & 299 & 0.40 \\
\hline \multicolumn{3}{|l|}{ Group 2} \\
\hline${ }^{\prime} \ldots \ldots \ldots \ldots \ldots \ldots \ldots \ldots \ldots \ldots \ldots \ldots$ & 36 & 0.68 \\
\hline Cyclones $>155 \mathrm{MW}, \ldots \ldots \ldots \ldots \ldots \ldots \ldots \ldots \ldots$ & 55 & 0.86 \\
\hline Wet-Bottom, Wall-Fired $>65 \mathrm{MW}, \ldots \ldots \ldots \ldots \ldots$ & 26 & 0.84 \\
\hline Vertically Fired $[, \ldots, \ldots, \ldots, \ldots, \ldots, \ldots, \ldots$ & 28 & 0.80 \\
\hline
\end{tabular}

Source: United States Environmental Protection Agency, Nitrogen Oxides Emission Reduction Program, Final Rule for Phase II, Group 1 and Group 2 Boilers (http://www.epa.gov/docs/acidrain/noxfs3.html).

provision provides for coordination of $\mathrm{NO}_{\mathrm{x}}$ reduction initiatives under Titles $I$ and IV and promotes the goal of achieving necessary $\mathrm{NO}_{\mathrm{x}}$ reductions in a cost-effective manner. ${ }^{72}$

\section{Discussion of Air Toxics-Title III}

Under Title III of CAAA90, EPA is responsible for determining the hazards to public health posed by 189 hazardous air pollutants (HAP's). Title III specifically directs EPA to perform a study of the HAP's (also known as air toxics) to determine which hazards are likely to occur as a result of emissions by electric utility steamgenerating units, and to report the results to Congress. This study must be completed prior to promulgating any new regulations. CAAA90 also required EPA to recommend whether to control 189 air toxics, including mercury, by November 15, 1995. However, this deadline has been delayed. The mercury studies, while still pending, are intended to evaluate human health and ecological impacts of all mercury emitting sources in the United States. ${ }^{73}$ EPA has submitted to Congress an interim final report on the "Study of Hazardous Air Pollutant Emissions from Electric Utility Steam Generating Units" regarding the emissions, fate, and transport of utility HAP's. ${ }^{74}$ EPA has not evaluated exposure to mercury emissions from utilities for humans or wildlife in this interim report and plans to publish a final utility HAP report at a later date.

In addition to the studies required by CAAA90, studies on air toxics and mercury and potential regulations are being considered at the State level. Minnesota, Florida, and New Jersey are among those States that are currently addressing the potential impact of air toxics. ${ }^{75}$

Title III states that individual facilities may not exceed emissions of 10 tons per year $(t / y r)$ for a single $\mathrm{HAP}$ or $25 \mathrm{t} / \mathrm{yr}$ for any combination of HAP's. However, even if a power plant falls below these limits, control requirements for a single HAP could be imposed because limits can be lowered based on pollutant potency, persistence, bioaccumulation, or other factors. ${ }^{76}$ Mercury is a special concern because of its environmental behavior and the level of mercury contamination in water due to its bioaccumulation in fish. The level of mercury in raw coal is very small, typically only $0.05-0.10$ parts per million (ppm). This results in trace mercury concentrations from stack emissions of about 1 part per billion (ppb).

The U.S. Department of Energy (DOE) and the Electric Power Research Institute (EPRI) have performed extensive research on mercury. Results of the studies show significant variations in the amount of mercury removed by

72 U.S. Environmental Protection Agency, Nitrogen Oxides Emission Reduction Program, Final Rule for Phase II, Group 1 and Group 2 Boilers (http://www.epa.gov/docs/acidrain/noxfs3.html).

73 "EPA's Utility Toxics Report Will Be Delayed by at Least Two Months," Inside EPA's Clean Air Report (April 18, 1996$),$ p. 18.

74 Environmental Protection Agency, Office of Air Quality Planning and Standards, Study of Hazardous Air Pollutant Emissions from Electric Utility Steam Generating Units-Interim Final Report, EPA-453/R-96-013a (Research Triangle Part, NC, October 1996).

75 Teresa Hansen, "Air Toxicities Controls Unlikely," Electric Light \& Power (December 1995), p. 21.

76 Ibid.

77 "Improving Common Control Devices," Atmospheric Monitoring \& Abatement News (August 1995), No. 7, Vol. 3. 
electrostatic precipitators; these variations range from about 15 percent to 75 percent. Although data are limited, mercury removed from baghouses ranges from 10 percent to 70 percent. Mercury removal from wet scrubber systems ranged from 0 percent to about 50 percent. ${ }^{78}$ Much of the variation in removal performance may have been caused by the difference in the chemical form of the mercury in the flue gas. Mercury emissions from coal combustion have been shown to vary considerably from site to site. The chemical composition of coal varies widely and so does the concentration of mercury. If EPA decides that hazardous air pollutants pose a risk, then it must propose air toxic emissions controls by November 15, 1998 , and make them final by November 15, 2000. Such controls are potentially costly, especially for coal-fired power plants. ${ }^{79}$

\section{Technology Refinements}

The electric industry faces a number of potential environmental control regulations in addition to Title IV of CAAA90, such as fine particulate and air-toxics (Title III) regulations; solid-waste restrictions; global warming and carbon dioxide $\left(\mathrm{CO}_{2}\right)$ discharges; water management; and differing State, regional, and local regulations. Increased competition and the eventual disappearance of the regulated rate of return have caused the electric utility industry to attempt to reduce the costs of compliance with Title IV of Phase II in 2000 or to coordinate the compliance strategies so they also comply with other regulations. Also, efforts may be necessary to meet regional $\mathrm{NO}_{x}$ reduction requirements associated with Title I and ozone nonattainment. Thus, refinements continue with the primary $\mathrm{NO}_{\mathrm{x}}$ reduction technologies and with particulate control.

\section{Nitrogen Oxides Reduction}

Combustion in conventional pulverized coal systems occurs at temperatures that produce significant amounts of thermal $\mathrm{NO}_{x}$ as well as fuel-bound $\mathrm{NO}_{x}$. Advanced techniques for post-combustion $\mathrm{NO}_{\mathrm{x}}$ control include Selective Catalytic $\mathrm{NO}_{x}$ Reduction (SCR) and Selective Noncatalytic Reduction (SNCR). SCR technology consists of injecting ammonia into boiler flue gas and passing it through a catalyst bed where the $\mathrm{NO}_{x}$ and ammonia react to form nitrogen and water vapor. SNCR involves uncatalyzed or thermal reaction with ammonia. SCR technology is now incorporated in some new coalfired plants and is the mainstay of $\mathrm{NO}_{x}$ reduction efforts. Several large coal-fired units have incorporated SCR technology, including two plants in New Jersey and one in Florida, and a fourth plant in Florida with full-flow SCR units. ${ }^{80}$ One development that may enhance SCR applications even further is the evolution of lightweight catalysts. Some of these new catalysts weigh more than 50 percent less than traditional extruded ceramic or metalbased catalysts.

Another technology for controlling $\mathrm{NO}_{x}$ emissions from wet-bottom boilers - SNCR - was demonstrated by Public Service Electric and Gas Company of New Jersey (PSE\&G), at its coal-fired Mercer Station. This technology is less costly than SCR. The New Jersey demonstration should benefit other utilities with wall-turbo-fired boilers and cyclone-fired boilers for which SNCR is now a viable $\mathrm{NO}_{x}$ control option. The results indicate that SNCR may be adequate to bring some boilers into compliance with CAAA90. In addition, PSE\&G demonstrated in subsequent testing that SNCR can be combined in a hybrid SNCR/SCR system to achieve 90 percent $\mathrm{NO}_{x}$ reductions-a level equivalent to that achievable with conventional $\mathrm{SCR}^{81}$

Other methods to reduce $\mathrm{NO}_{x}$ emissions include replacing or tuning pulverizers, upgrading components, balancing coal and air flows to individual burners, and correlating coal specifications with boiler operating parameters more closely. Experts concede that these strategies can approach or exceed the reduction available from low- $\mathrm{NO}_{\mathrm{x}}$ burners. So much progress has been made in reducing $\mathrm{NO}_{x}$ emissions through combustion modifications that the term low-NO $\mathrm{N}_{\mathrm{x}}$ burner has less meaning today than when the CAAA90 was passed. The entire fuel preparation and furnace system must be optimized for minimum $\mathrm{NO}_{x}$ formation. ${ }^{82}$

Control system upgrades, which are often applied in combination with hardware modifications and instrumentation additions, can also achieve low-cost $\mathrm{NO}_{x}$ reductions. By measuring and manipulating air and/or fuel flows accurately with better process software and computer technologies, it is possible to automate and optimize the

78 Teresa Hansen, “Air Toxicities Controls Unlikely," Electric Light \& Power (December 1995), p. 21.

79 Ibid.

80 Jason Makansi, "Despite market uncertainty, a few new approaches come forward," Power (March, 1996), p. 25.

81 Electric Power Research Institute, PSE\&G Demonstrated SNCR Technology for NOx Control at Mercer Station (July/August 1996), p. 34.

82 Jason Makansi, "Work with existing hardware to maximize emissions control," Power (March 1995), p. 41. 
process. A variety of software packages have been developed for this process, resulting in sizeable reductions in $\mathrm{NO}_{x}$ emissions. These software packages have the potential to greatly reduce or possibly eliminate the hardware component of a $\mathrm{NO}_{x}$ control retrofit. ${ }^{83}$

\section{Particulate Collection}

U.S. utilities have used electrostatic precipitators (ESP's) and fabric filters or baghouses to control particulate emissions at coal-fired plants for some time. These devices have enabled utilities to meet applicable emissions and opacity standards. However, the possible impact of more stringent particulate emissions requirements and the differences in ash quality as coals are switched to lowsulfur have prompted utilities to make these control devices more effective. Given these factors and the pressures of competition, utilities with coal-fired plants will have to determine how to cost-effectively improve particulate control. A list of some options follows.

- Flue-gas conditioning (FGC), usually with sulfur trioxide $\left(\mathrm{SO}_{3}\right)$ injection, is a proven method of improving the collection of fly ash in ESP's. With increasing competition among suppliers in emissions-control systems, costs are falling and performance is improving. This system converts the $\mathrm{SO}_{2}$ already in the gas stream into $\mathrm{SO}_{3}$ and avoids a separate feedstock/reagent. This system has been demonstrated and commercially installed..$^{84}$

- Another approach to improving fly ash removal is to enhance the conventional FGC process electro- statically. The electrostatic force promotes the attraction between $\mathrm{SO}_{3}$ and fly ash particle surfaces. A discharge frame with a high-tension power source is added to the ductwork upstream, which complements the diffusion mass transfer process that normally occurs with FGC. ${ }^{85}$

- In the last 2 years the Compact Hybrid Particulate Collection System (COHPAC) was developed, which is a high-efficiency, compact pulse-jet fabric filter (PJFF) that operates downstream as a separate collector of an existing ESP or in the last one or two fields of the ESP. COHPAC systems utilize PJFF's because utilities can pack the filter bags closely in baghouse compartments with a reduction in baghouse size and cost when compared to a conventional fabric-filter application. At a minimum, COHPAC systems allow utilities to upgrade some underperforming ESP's and achieve clear stacks. In addition, because this process collects fine particles efficiently, it shows promise for its ability to control air toxics as well. ${ }^{86} 87$

These techniques can form the basis for improvements in basic power plant design when emissions control considerations are factored into every major power plant component. Selection of techniques or equipment is based on optimizing project priorities, such as initial capital cost, operating costs, efficiency, emissions, maintainability, and unit operating flexibility. Most of these techniques seek to accomplish critical processes in smaller spaces, which leads to constraints on residence times, flow distribution, measuring capabilities, maintenance procedures, and operating flexibility.

83 Ibid.

84 Ibid.

85 Ibid.

86 Jason Makansi, "Despite market uncertainty, a few new approaches come forward," Power (March 1996), p. 25.

87 Ramsy Chang, "COHPAC compacts emission equipment into smaller, denser unit: Compact Hybrid Particulate Collector," Power Engineering (July 1996), p. 22 


\section{Phase II}

Increased competition has caused the electric utility industry to face major changes in the way it is structured. On April 24, 1996, the Federal Energy Regulatory Commission (FERC) issued the final rule, Order No. $888,{ }^{88}$ in response to provisions of the Energy Policy Act (EPACT) of 1992. Order No. 888 opens wholesale electric power sales to competition and requires each utility that owns transmission lines to allow buyers and sellers of power the same access to those lines as the utility provides to its own generation.

In a noncompetitive environment, State regulators allowed electric utilities to pass on the costs of pollution control requirements to consumers in the form of higher electricity rates. In a competitive market, utilities that have higher rates because of environmental controls would be at a relative disadvantage, while those with lower overall costs could increase their market share. With increasing competition and with Phase $I I$ of CAAA90 slated for implementation on January 1,2000, utilities are showing less interest in making capital investments in expensive pollution control equipment, are uncertain about cost recovery, and want to be more competitive. In 1995, an Edison Electric Institute survey of investor-owned utilities for Phase II compliance shows they have not yet significantly increased construction spending; however, utilities are expected to spend $\$ 789$ million per year from 1996 through $1998 .^{89}$

\section{Current Strategies for Phase II}

Compliance with Phase I of CAAA90 has required major investments by utilities. In Phase I, allowances are allocated at the rate of 2.5 pounds of sulfur dioxide $\left(\mathrm{SO}_{2}\right)$ times the number of million British thermal units (Btu's) consumed in the 1985-1987 baseline.
However, Phase II, which takes effect on January 1, 2000, will have an even larger impact on more generating units than Phase I. In Phase II, allowances are allocated at the rate of 1.2 pounds of $\mathrm{SO}_{2}$ times the number of million Btu's consumed in the baseline. Although utilities have not finalized their plans to comply with the more stringent Phase II requirements, most of them have elected to overcomply with Phase I requirements, thus creating a surplus of excess allowances. This is one way of deferring higher-cost Phase II compliance strategies beyond 2000.

The following is a general discussion of what is currently known about compliance plans for Phase II. It is derived from a survey of 116 utilities conducted by Industrial Information Services of Reno, Nevada. Forty-one percent of the respondents plan to switch fuels. The acquisition of acid-rain emissions allowances is the second most popular compliance choice, with 28 percent indicating they will do so..$^{90}$

\section{Fuel Switching/Blending}

Fuel switching/blending to lower sulfur coal in generating units will probably be the predominant strategy used by utilities to comply with Phase $\Pi$ of the CAAA90, just as it was for Phase I. Compared to scrubbing and repowering, the fuel switching/blending strategy involves lower capital costs, takes less time to implement, and offers flexibility in meeting future emission requirements. Because power plants are generally designed for a particular type of coal, switching to a different coal, such as lower sulfur coal, requires an assessment of the new fuel's effects on the individual plant. The new coal can affect the performance of boilers and ESP's, as well as operations and maintenance procedures. ${ }^{91}$

\footnotetext{
88 "Promoting Wholesale Competition Through Open Access Non-Discriminatory Transmission Services by Public Utilities; Recovery of Stranded Costs by Public Utilities and Transmitting Utilities," Docket Nos. RM95-8-000 and RM94-7-001, Order No. 888 (April 24, 1996).

${ }^{89}$ Edison Electric Institute, Financial Information, 1995 Construction Expenditures Surveys (Washington, DC, September 9, 1996).

90 "Fuel-Switching Outpacing Scrubbers as U.S. Utilities Comply with CAA," Asbestos \& Lead Report, No. 1, Vol. 8 (January 23, 1995).

91 For the impact of lower sulfur coal on an individual plant, see Energy Information Administration, Electric Utility Phase I Acid Rain Compliance Strategies for the Clean Air Act Amendments of 1990, DOE/EIA-0582 (Washington, DC, March 1994), p. 13.
} 
Because lower sulfur coal is usually lower in heating value (Btu rating), fuel switching/blending may require the firing of a larger volume of coal to generate the same amount of power. A larger volume of coal requires more storage space and an increase in coal-handling facilities. Generating capability could be constrained by coalhandling considerations if the volume of lower sulfur coal is increased substantially. In addition, an increased volume of coal could require ESP modifications to handle the increased fly ash or boiler derating so as not to overload the ESP. Also, the boiler heat rate could be adversely affected if boiler redesign is required to accommodate the new lower sulfur coal.

Burning western lower sulfur coal results in more particulate matter (PM) emissions than burning eastern high-sulfur coal. In addition, the coal resistivity ${ }^{92}$ may change and degrade ESP collection efficiency. These changes can require alterations to the ESP's. Finally, different coals may cause different HAP emissions. Because utility coal-fired plants are designed for certain coal types, it takes a couple of years to test fire several lower sulfur coals to determine which one reduces emissions.

\section{Co-firing With Natural Gas}

Natural gas is the cleanest of the fossil fuels available for use in power generation and has the potential to reduce emissions without great cost. The use of nearly sulfur-free natural gas instead of sulfur-containing coal can significantly reduce $\mathrm{SO}_{2}$ emissions, and the potential exists for reduced $\mathrm{NO}_{\mathrm{x}}$ emissions, depending on burner characteristics. Co-firing with natural gas can also reduce HAP's, carbon dioxide, fly ash, and disposal needs. Natural gas firing has lower operation and maintenance costs than coal firing. However, the fuel costs are higher, and access to a nearby pipeline is a requirement for this option to be economical. In addition, few coal-fired boilers are designed to co-fire natural gas. Although many can be retrofitted, usually with separate burners for gas and coal, a boiler switched from coal to gas may experience a decrease in efficiency. However, the high capital cost of retrofitting coal-fired boilers to burn natural gas is the reason that utilities seldom choose this strategy for meeting emission requirements of CAAA90.

\section{Allowances}

Just as it has been for Phase I, allowance acquisition is expected to be the second most popular choice for Phase II compliance-after fuel switching/blending. According to a study by Resource Data International, a Colorado research firm, utilities are over complying because the price of buying and using lower sulfur coal is less than originally projected and because of the flexibility provided by the EPA Title IV sulfur dioxide allowance program. The coincidence of mining efficiencies and rail deregulation and competition have made clean-burning coal from Wyoming's Powder River Basin as cheap, or cheaper, than the high-sulfur coal of the Midwest. ${ }^{93}$

Allowance credits are so inexpensive today that years of allowance credits can be purchased for less than the cost of the capital equipment for pollution control. Allowance prices are much lower than expected primarily because of the reduction in lower sulfur coal prices. Allowance and the coal markets are increasingly integrated. ${ }^{94}$ This activity in emission allowance credits, which can be traded or sold, creates the possibility of running a pollution control system as a revenue source at least in the short term. ${ }^{95}$

The typical allowance sales have been made by an eastern utility that has installed scrubbers to a midwestern utility without scrubbers. Also, many utilities bank their allowances. For instance, the Atlantic City Electric Company, which owns two coal-fired generating stations, cut its emissions in half between 1990 and 1995, primarily by adding a stack scrubber. The excess emission allowances will be held for use in Phase II. The allowances will be depleted by 2012, so the company must decide before then how to meet future long-term generating and emission requirements. ${ }^{96}$

92 A layer of ash, resistant to being charged, accumulates on the precipitator causing the degrading of the performance and necessitating manual cleaning. Sodium treatment of the particulate material can be used to reduce ash resistivity and improve the precipitator performance.

93 "Environment Week: Environmental Brokerage Services $\mathrm{SO}_{2}$ Allowance's Sharp Price Decline Attributed Mainly to Low-Sulfur Coal," Air/Water Pollution Report, No. 4, Vol. 34 (January 19, 1996).

${ }_{94}$ Massachusetts Institute of Technology, for the Proceedings of the Second Workshop on Energy Externalities, Brussels, September 9-10, 1996, Draft, The U.S. Allowance Trading Program for Sulfur Dioxide: An Update After the First Year of Compliance (Cambridge, MA, October 29, 1996), p. 14.

95 "Pollution Control for Cash," Independent Energy, Vol. 25, No. 1 (January 1995), p. 52.

96 "Environment Week: Environmental Brokerage Services $\mathrm{SO}_{2}$ Allowance's Sharp Price Decline Attributed Mainly to Low-Sulfur Coal," Air/Water Pollution Report, No. 4, Vol. 34 (January 19, 1996). 
Some utilities have expressed that the Federal tax system interferes with the intended operation of the emission allowance market. Because the Internal Revenue Service (IRS) assigns a zero tax basis to the allowances in the hands of the original owners, all proceeds from the sale of allowances are fully taxable and subject to a capital gains tax. Internal utility uses, however, such as stockpiling of emissions allowances, do not trigger taxation. This situation obviously favors internal use by utilities. Legislation has been submitted to Congress to address this problem. ${ }^{97}$

The $\mathrm{SO}_{2}$ allowance and market trading system has been successful in producing $\mathrm{SO}_{2}$ reductions faster and less expensively than expected. It has also encouraged technological and economic innovation. For example, highsulfur coal companies are buying allowances to package with their coal sales. By bundling allowances with the coal, these companies can compete with lower sulfur coal because the allowances included in the "bundle" compensates for the higher sulfur content.

\section{Scrubbers}

A number of scrubbers planned for Phase II are being deferred. For example, scrubbers on Mount Storm No. 1 and No. 2, Virginia Power; Montour, Pennsylvania Power and Light (PP\&L); and Homer City No. 3, Pennsylvania Electric are no longer planned for 2000, although they may be retrofitted later. The two 750-megawatt coal-fired generating units at the Montour station will not be fitted with scrubbers before 2004 at the earliest, a decision that PP\&L projects will save an estimated $\$ 400$ million in capital costs over the next 5 years. PP\&L will buy lower sulfur coal, use emission allowances already earned, and purchase additional allowances $^{98}$ to achieve Phase II compliance.

Carolina Power \& Light plans to switch all of its plants to compliance coal by 2000 . In 2007, it will install a scrubber at one of the largest of its 20 coal-fired units. Dayton Power \& Light, owner or part-owner of a number of plants located in the high-sulfur coalfields of Ohio, plans to switch to lower sulfur coal and to bank a substantial number of credits during Phase I, to make up for the expected allowance deficits after $2000 . .^{99}$
The Electric Power Research Institute (EPRI) estimates that no more than 12 gigawatts to 20 gigawatts of generation capacity may be scrubbed to comply with Phase II requirements, and the actual total is likely to be closer to 12 gigawatts than 20 gigawatts. This modest scrubber forecast reflects the impact of fuel switching, low $\mathrm{SO}_{2}$ allowance prices, and the delay in fulfilling scrubber commitments for as long as possible. The utilities that are over complying with Phase I have allowance credits they can use to delay their own Phase II scrubbing, or to sell to other utilities that want to delay Phase II actions. ${ }^{100}$ Planning and building a scrubber takes 4 years, so in many cases capital for scrubbers will not be committed until after the year 2000 .

This scenario could change if EPA air toxics regulations are issued in the future, requiring reductions in air toxics, including mercury. Most of these hazardous emissions are fairly easily controlled, except mercury, with wet scrubbers. Some States in the East and the Midwest are considering air toxics control.

\section{Repowering}

As of January 1,1996, fossil-fuel electric operable capacity accounted for 72 percent of U.S. electric utility net summer generating capability. ${ }^{101}$ In the year 2010, average age-weighted by capacity - of the Nation's coal-fired units will be 39 years, gas-fired units 40 years, and oilfired units 40 years (Figure 20). One method for maintaining generating capacity online or adding capacity to a utility system, while working toward meeting $\mathrm{SO}_{2}$ requirements, is to repower older fossil-fuel units.

Repowering existing power plants can be an economical way to turn unused or underutilized plants into profitable assets. The newer technology can be used to reduce emissions to comply with CAAA90 and increase efficiency. The technologies used for repowering include gas turbines; heat-recovery steam generators and feed water heaters; and coal-gasification combined-cycle, atmospheric fluidized-bed, or pressurized fluidized-bed combustion combined-cycle systems.

Repowering candidates include oil- and gas-fired plants as well as coal-fired plants that face significant emissions

\footnotetext{
97 "Why Taxes Do Distort Emission Trading," Fortnightly (February 15, 1995), p. 42.

98 "U.S. Utilities Opt Against Scrubbing," International Coal Report (October 30, 1995).

99 Ibid.

100 Ibid.

${ }^{101}$ Energy Information Administration, Inventory of Power Plants in the United States, DOE/EIA-0095(95) (Washington, DC, December 1996), p. 20.
} 
Figure 20. Average Age (Weighted by Capacity) of Fossil-Fuel Units, 1990, 2000, and 2010, as of January 1, 1996

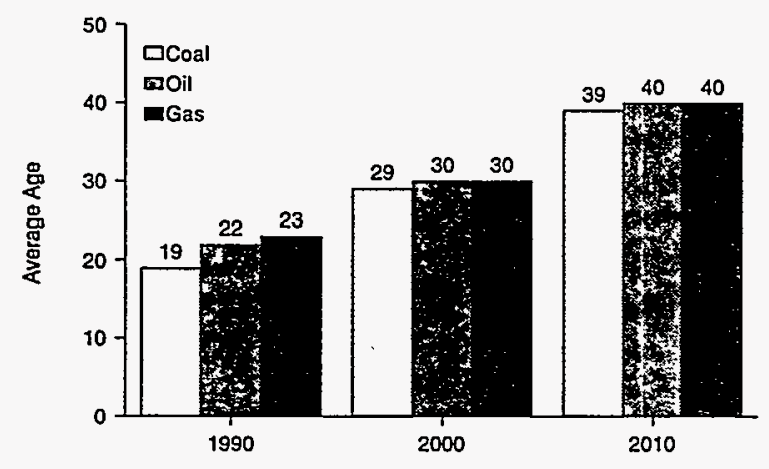

Note: The average unit age includes existing units, planned retirements, and planned capacity additions.

Source: Energy Information Administration, Form EIA-860, "Annual Electric Generator Report."

reductions to satisfy Phase II of CAAA90. Repowering power plants usually increases their capacity, the extent of which depends on the repowering procedure is used. However, even though Title IV includes specific incentives to repower fossil plants with clean-coal technology, barring the DOE's Clean Coal Technology projects, no utility has announced a repowering project for the sole purpose of meeting CAAA90 Phase I or II emission requirements. ${ }^{102}$

Most of the fossil units proposed for repowering from 1996 through 2005 (Table 14) have relatively small net summer capabilities. The proposed repowering of fossil capacity from 1996 through 2005 is 2,501.1 megawatts. This includes repowering 589.5 megawatts of natural gas steam turbine-boilers to burn natural gas again, repowering 219.0 megawatts of bituminous steam-turbine boilers to burn bituminous coal again, repowering 536.9 megawatts of natural gas combustion turbines to burn natural gas, repowering 43.2 megawatts of No. 2 fuel oil combustion turbines to burn natural gas, and repowering 80.0 megawatts of No. 6 fuel oil steam turbines to burn natural gas. The last two repowering options are the only ones that change fuel. Repowering with natural gas is a significant option for fossil units.
Some estimates indicate that utilities could bank an excess of up to 15 million $\mathrm{SO}_{2}$ allowance credits by the time Phase II begins on January 1, 2000. After the Phase I credits are depleted, the utilities will then have to reduce emissions, and repowering can help meet that need. Because repowering is cheaper than building a new generating unit, repowering will be used to meet some of the future capacity needs. ${ }^{103}$

\section{Retirements}

The planned fossil-fuel capacity retirements slated to take place from 1996 through 2005 (Table 15) include much smaller percentages of coal-fired units than petroleum or gas when compared to the generator nameplate capacity for the energy source. Just six coal-fired units are projected to retire before the start of Phase II, with six other coal-fired units retiring after the year 2000. However, 79 petroleum- and 70 gas-fired units will retire throughout the 10-year period.

\section{Synergy With Clean Air Act Requirements}

As utilities make plans to meet the requirements of CAAA90 for $\mathrm{SO}_{2}$ and $\mathrm{NO}_{x}$, they must also consider other existing Clean Air Act (CAA) requirements and possible new regulations. Through 2005, the CAÁ requires EPA to consider a number of actions and new regulations that would directly or indirectly result in the need to reduce emissions from electric power generation (Figure 21).

CAAA90 contain many requirements that will affect the electric power generating industry well into the future, such as $\mathrm{NO}_{x}$ limitations under Titles I and IV, New Source Performance Standards, new Ozone and Fine Particle Standards, and possibly, Utility Air Toxics requirements. EPA has traditionally implemented standards and requirements on a statutory provision-by-provision basis. This approach has been effective in protecting the environment though it is not likely to be the most economically efficient. For this reason, EPA is working with power generators to develop a more efficient approach called the Clean Air Power Initiative (CAPI).

102 Teresa Hansen, "Utilities to Spend \$1.4 Billion on Power Plant Maintenance," Electric Light \& Power (February 1996), p. 17.
103 "SO $\mathrm{SO}_{2}$ Banking Allows Utilities to Delay Repowering of Coal-Fired Plants," Energy Report, No. 42, Vol. 23 (October 30, 1995). 
Table 14. Fossil Units Proposed for Repowering, 1996-2005, as of January 1, 1996

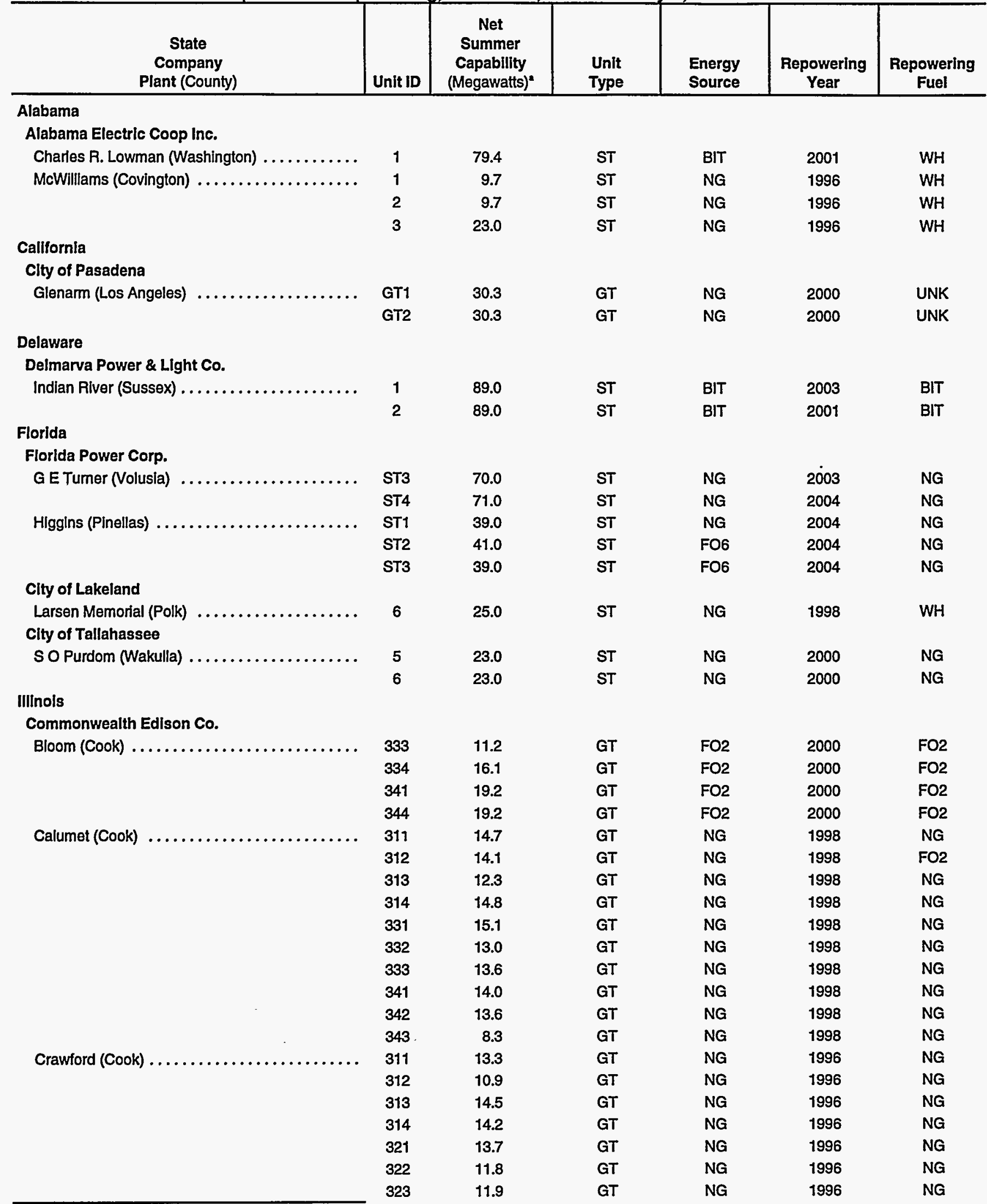

See notes at end of table. 
Table 14. Fossil Units Proposed for Repowering, 1996-2005, as of January 1, 1996 (Continued)

\begin{tabular}{|c|c|c|c|c|c|c|}
\hline $\begin{array}{c}\text { State } \\
\text { Company } \\
\text { Plant (County) } \\
\end{array}$ & Unit ID & $\begin{array}{c}\text { Net } \\
\text { Summer } \\
\text { Capability } \\
\text { (Megawatts) }^{\mathrm{a}}\end{array}$ & $\begin{array}{l}\text { Unit } \\
\text { Type }\end{array}$ & $\begin{array}{l}\text { Energy } \\
\text { Source }\end{array}$ & $\begin{array}{c}\text { Repowering } \\
\text { Year }\end{array}$ & $\begin{array}{c}\text { Repowering } \\
\text { Fuel }\end{array}$ \\
\hline \multirow[t]{5}{*}{ Crawford (Cook) (continued) } & 324 & 10.8 & GT & NG & 1996 & NG \\
\hline & 331 & 10.9 & GT & NG & 1996 & NG \\
\hline & 332 & 10.0 & GT & NG & 1996 & NG \\
\hline & 333 & 13.5 & GT & NG & 1996 & NG \\
\hline & 334 & 13.3 & GT & NG & 1996 & NG \\
\hline \multirow{13}{*}{ Electric Junction (Kane) . . . . . . . . . . . . . . } & 311 & 14.6 & GT & NG & 1996 & NG \\
\hline & 312 & 13.1 & GT & NG & 1996 & NG \\
\hline & 313 & 14.4 & GT & $N G$ & 1996 & NG \\
\hline & 314 & 14.9 & GT & NG & 1996 & NG \\
\hline & 321 & 14.3 & GT & NG & 1996 & NG \\
\hline & 322 & 15.5 & GT & NG & 1996 & NG \\
\hline & 323 & 7.3 & GT & $N G$ & 1996 & NG \\
\hline & 324 & 8.7 & GT & $N G$ & 1996 & $N G$ \\
\hline & 331 & 15.6 & GT & $N G$ & 1996 & $N G$ \\
\hline & 332 & 15.3 & GT & $N G$ & 1996 & NG \\
\hline & 333 & 9.7 & GT & $N G$ & 1996 & NG \\
\hline & 334 & 10.4 & GT & FO2 & 1996 & FO2 \\
\hline & 343 & 10.4 & GT & $N G$ & 1996 & NG \\
\hline \multirow[t]{8}{*}{ Fish (Cook) $\ldots \ldots \ldots \ldots \ldots \ldots \ldots \ldots$} & 311 & 20.0 & JE & $\mathbf{J F}$ & 1999 & JF \\
\hline & 312 & 19.0 & JE & JF & 1999 & JF \\
\hline & 321 & 18.0 & JE & JF & 1999 & JF \\
\hline & 322 & 20.0 & JE & $\mathrm{JF}$ & 1999 & JF \\
\hline & 331 & 20.0 & JE & $\mathrm{JF}$ & 1999 & JF \\
\hline & 332 & 20.0 & JE & JF & 1999 & JF \\
\hline & 341 & 20.0 & JE & $\mathrm{JF}$ & 1999 & JF \\
\hline & 342 & 20.0 & JE & JF & 1999 & JF \\
\hline \multirow[t]{8}{*}{ Joliet 9 (Will) } & 311 & 14.1 & GT & $N G$ & 1996 & NG \\
\hline & 312 & 15.5 & GT & $N G$ & 1996 & $N G$ \\
\hline & 313 & 8.1 & GT & NG & 1996 & NG \\
\hline & 314 & 12.0 & GT & NG & 1996 & NG \\
\hline & 321 & 15.2 & GT & NG & 1996 & NG \\
\hline & 322 & 12.8 & GT & $N G$ & 1996 & NG \\
\hline & 323 & 11.0 & GT & $N G$ & 1996 & NG \\
\hline & 324 & 14.2 & GT & $N G$ & 1996 & NG \\
\hline \multirow[t]{3}{*}{ Lombard (Du Page) . .................. } & 311 & 18.6 & JE & $\mathrm{JF}$ & 1998 & NG \\
\hline & 321 & 17.4 & JE & $\mathrm{JF}$ & 1998 & JF \\
\hline & 322 & 17.8 & JE & $\mathrm{JF}$ & 1998 & NG \\
\hline \multirow[t]{7}{*}{ Sabrooke (Winnebago) } & 311 & 14.1 & GT & FO2 & 1997 & FO2 \\
\hline & 312 & 13.0 & GT & FO2 & 1997 & FO2 \\
\hline & 321 & 13.9 & GT & $\mathrm{FO} 2$ & 1997 & $N G$ \\
\hline & 322 & 15.8 & GT & FO2 & 1997 & $N G$ \\
\hline & 331 & 14.0 & GT & FO2 & 1997 & FO2 \\
\hline & 332 & 13.5 & GT & $\mathrm{FO} 2$ & 1997 & NG \\
\hline & 341 & 10.6 & GT & FO2 & 1997 & FO2 \\
\hline \multirow[t]{4}{*}{ 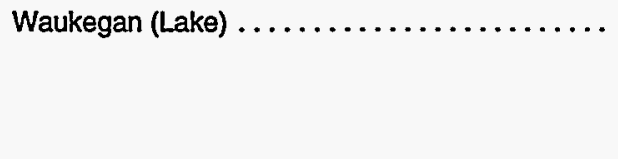 } & 311 & 24.6 & JE & JF & 1997 & $\mathbf{J F}$ \\
\hline & 312 & 29.9 & JE & JF & 1997 & FO1 \\
\hline & 321 & 28.8 & JE & JF & 1997 & FO1 \\
\hline & 322 & 29.9 & JE & JF & 1997 & F01 \\
\hline
\end{tabular}

\footnotetext{
See notes at end of table.
} 
Table 14. Fossil Units Proposed for Repowering, 1996-2005, as of January 1, 1996 (Continued)

\begin{tabular}{|c|c|c|c|c|c|c|}
\hline $\begin{array}{c}\text { State } \\
\text { Company } \\
\text { Plant (County) }\end{array}$ & Unit ID & $\begin{array}{c}\text { Net } \\
\text { Summer } \\
\text { Capability } \\
\text { (Megawatts) }\end{array}$ & $\begin{array}{l}\text { Unit } \\
\text { Type }\end{array}$ & $\begin{array}{l}\text { Energy } \\
\text { Source }\end{array}$ & $\begin{array}{c}\text { Repowering } \\
\text { Year }\end{array}$ & $\begin{array}{c}\text { Repowering } \\
\text { Fuel }\end{array}$ \\
\hline \multicolumn{7}{|l|}{$\begin{array}{l}\text { Mississippi } \\
\text { City of Clarksdale }\end{array}$} \\
\hline $\begin{array}{l}\text { Wilkins (Coahoma) } \ldots \ldots \ldots \ldots \ldots \ldots \ldots \ldots \ldots \\
\text { Public Service Commission of Yazoo City }\end{array}$ & 8 & 12.0 & GT & NG & 1996 & NG \\
\hline \multicolumn{7}{|l|}{ South Mlssissippl EI Power Assn. } \\
\hline Moselle (Jones) $\ldots . \ldots \ldots \ldots \ldots \ldots \ldots$ & 3 & 59.0 & ST & NG & 2001 & NG \\
\hline \multicolumn{7}{|l|}{ Oklahoma } \\
\hline \multicolumn{7}{|l|}{ Pennsylvanla } \\
\hline $\begin{array}{l}\text { Chambersburg Dlesel (Franklin) } \ldots \ldots \ldots \ldots \ldots \\
\text { Pennsylvanla Electric Co. }\end{array}$ & 5 & 2.1 & IC & NG & 1996 & NG \\
\hline Warren (Warren) $\ldots \ldots \ldots \ldots \ldots \ldots \ldots$ & 2 & 41.0 & ST & BIT & 1997 & BIT \\
\hline \multicolumn{7}{|l|}{ Central Power \& LIght Co. } \\
\hline J L Bates (Hidalgo) $\ldots \ldots \ldots \ldots \ldots \ldots \ldots \ldots$ & 1 & 72.0 & ST & NG & 2002 & $N G$ \\
\hline 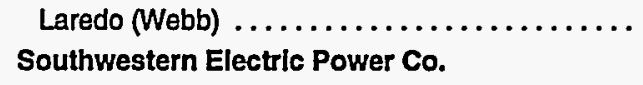 & 2 & 32.0 & ST & NG & 2001 & $N G$ \\
\hline
\end{tabular}

aSummer Capability is the maximum load that a generating unit, generating station, or other electrical apparatus can carry under specified conditions for a given period of time without exceeding approved limits of temperature and stress at the time of summer peak demand.

Notes: Unit Type: GT = Combustion (gas) Turbine, IC = Internal Combustion (diesel), ST = Steam Turbine-Boiler. Energy Source: BIT = Bituminous Coal, $F O 2=$ No. 2. Fuel OII, NG $=$ Natural Gas, $W H=$ Waste Heat, and UNK $=$ Unknown.

Source: Energy Information Administration, Form ElA-860, “Annual Electric Generator Report."

CAPI recognizes the need to improve and coordinate the development of air pollution regulations for the electric power generation sector. This sector includes utilities, independent power producers, cogenerators, and industrial boilers that produce electricity for their own needs. ${ }^{104}$ The numerous air pollution regulations and possible future regulatory mandates have potential synergies and conflicts. A complete analysis of utility compliance strategies should contemplate the entire range of environmental regulations, including CAAA90. For example, certain control options and strategies can reduce two or more pollutants at a lower cost than separate controls for each of those pollutants. Failure to take advantage of costeffective synergies and incremental compliance planning could increase control costs and utility user rates, and possibly reduce environmental benefits.

Title IV gives utilities the innovative allowance trading mechanism for $\mathrm{SO}_{2}$, as well as other potential marketbased mechanisms for $\mathrm{NO}_{x}$. However, this unprecedented flexibility gives rise to other concerns. Each fuel or process change adopted by a utility for $\mathrm{SO}_{2}$ compliance

${ }^{104}$ U.S. Environmental Protection Agency, EPA'S Clean Air Power Initiative, EPA Number (Washington, DC, April 1996), p. 1. 
Table 15. U.S. Electric Utility Planned Coal-, Petroleum-, and Gas-Fired Capacity Retirements, 1996-2005, as of January 1, 1996

\begin{tabular}{|c|c|c|c|c|c|c|}
\hline & \multicolumn{2}{|c|}{ Coal } & \multicolumn{2}{|c|}{ Petroleum } & \multicolumn{2}{|c|}{ Gas } \\
\hline & $\begin{array}{l}\text { Number } \\
\text { of Units }\end{array}$ & $\begin{array}{c}\text { Generator } \\
\text { Nameplate } \\
\text { (megawatts) }\end{array}$ & $\begin{array}{l}\text { Number } \\
\text { of Units }\end{array}$ & $\begin{array}{c}\text { Generator } \\
\text { Nameplate } \\
\text { (megawatts) }\end{array}$ & $\begin{array}{l}\text { Number } \\
\text { of Units }\end{array}$ & $\begin{array}{c}\text { Generator } \\
\text { Nameplate } \\
\text { (megawatts) }\end{array}$ \\
\hline $1996 \ldots \ldots \ldots \ldots \ldots$ & - & - & 4 & 60.9 & - & - \\
\hline $1997 \ldots \ldots \ldots \ldots \ldots \ldots \ldots$ & 2 & 60.0 & 20 & 43.0 & 5 & 147.6 \\
\hline $1998 \ldots \ldots \ldots \ldots \ldots \ldots$ & - & - & 1 & 2.5 & 3 & 39.4 \\
\hline $1999 \ldots \ldots \ldots \ldots \ldots \ldots$ & 4 & 392.0 & 2 & 24.6 & 2 & 48.5 \\
\hline $2000 \ldots \ldots \ldots \ldots \ldots \ldots$ & - & - & 6 & 19.5 & 2 & 125.6 \\
\hline $2001 \ldots \ldots \ldots \ldots \ldots \ldots$ & - & - & 8 & 67.0 & 4 & 165.0 \\
\hline $2002 \ldots \ldots \ldots \ldots \ldots \ldots$ & - & - & 14 & 232.5 & 30 & 776.3 \\
\hline $2003 \ldots \ldots \ldots \ldots \ldots \ldots$ & - & - & 11 & 424.6 & 1 & 22.5 \\
\hline $2004 \ldots \ldots \ldots \ldots \ldots \ldots$ & 3 & 159.2 & 11 & 472.4 & 9 & 664.1 \\
\hline $2005 \ldots \ldots \ldots \ldots \ldots \ldots$ & 3 & 155.1 & 2 & 83.7 & 14 & 611.9 \\
\hline U.S. Total $\ldots .$. & 12 & 766.4 & 79 & $1,430.6$ & 70 & $2,600.9$ \\
\hline
\end{tabular}

Source: Energy Information Administration, Form EIA-860, “Annual Electric Generator Report.”

will also affect other combustion emissions and byproducts. In addition to $\mathrm{SO}_{2}$ and $\mathrm{NO}_{x}$, the uncontrolled combustion of fossil fuels produces fly ash emitted as particulates; HAP's such as mercury; and other trace metals, radionuclides, and $\mathrm{CO}_{2}$. Many of these pollutants are subject to their own regulatory requirements. However, fossil-fuel utility units have not been regulated for HAP's, radionuclides, or $\mathrm{CO}_{2}$ emissions.

The uncontrolled combustion of fossil fuels also produces discharges of heat, waste water, and potentially large amounts of slag and bottom ash as solid waste. Thermal and wastewater discharges are regulated by the Clean Water Act (CWA). Thermal discharges are controlled through cooling towers, cooling pools, and recycling. Combustion wastes are regulated as solid wastes by the Resource Conservation and Recovery Act (RCRA), which requires waste generators to dispose of such wastes in sludge pools or landfills. ${ }^{105}$

A number of examples demonstrate the synergy of control options in reducing pollutants of fossil-fired utility plants. For example, many of the options to reduce particulate or $\mathrm{SO}_{2}$ emissions also reduce many of the air toxics. Utilities emit three types of air toxics: trace metals as particulates, mercury, and organic HAP's. Flue gas treatment technologies have important $\mathrm{HAP}-\mathrm{SO}_{2}$ control synergies. Except for mercury emissions, most trace metal emissions from coal-fired plants either are absorbed onto the fly ash or they precipitate with the bottom ash. Trace metal emissions absorbed onto the fly ash can be controlled by particulate control technologies, such as baghouses and ESP's. Mercury emissions can be partially removed with wet scrubber controls. Mercury emissions are usually reduced if a utility selects low-NO ${ }_{x}$ burners. Combustion temperatures are lowered, and mercury is absorbed in the fly ash. The mercury can then be effectively controlled with particulate controls. While particulate controls reduce trace metal emissions, and wet scrubbers partially reduce mercury, organic HAPs, and in particular, chlorine may not be controlled using these two methods. ${ }^{106}$

Fuel switching/blending between coals have different effects on co-pollutants and synergies, and a trade-off exists between Title IV and Title III in coal fuel switching and blending. When utilities switch from high-sulfur eastern coal to low-sulfur western coal, there is some indication that toxic particulates may result from combustion. In addition, coals vary by trace metal contents. Fuel switching or blending may reduce $\mathrm{SO}_{2}$ emissions,

\footnotetext{
${ }^{105}$ Argonne National Laboratory, Policy and Economic Analysis Group, Decision and Information Sciences Division, Synergies and Conflicts in Multimedia Pollution Control Related to Utility Compliance with Title IV of the Clean Air Act Amendments of 1990, ANL/DIS/TM-3 (January 1994), P. 4.

${ }_{106}^{10}$ Ibid., Pp. 79-80.
} 


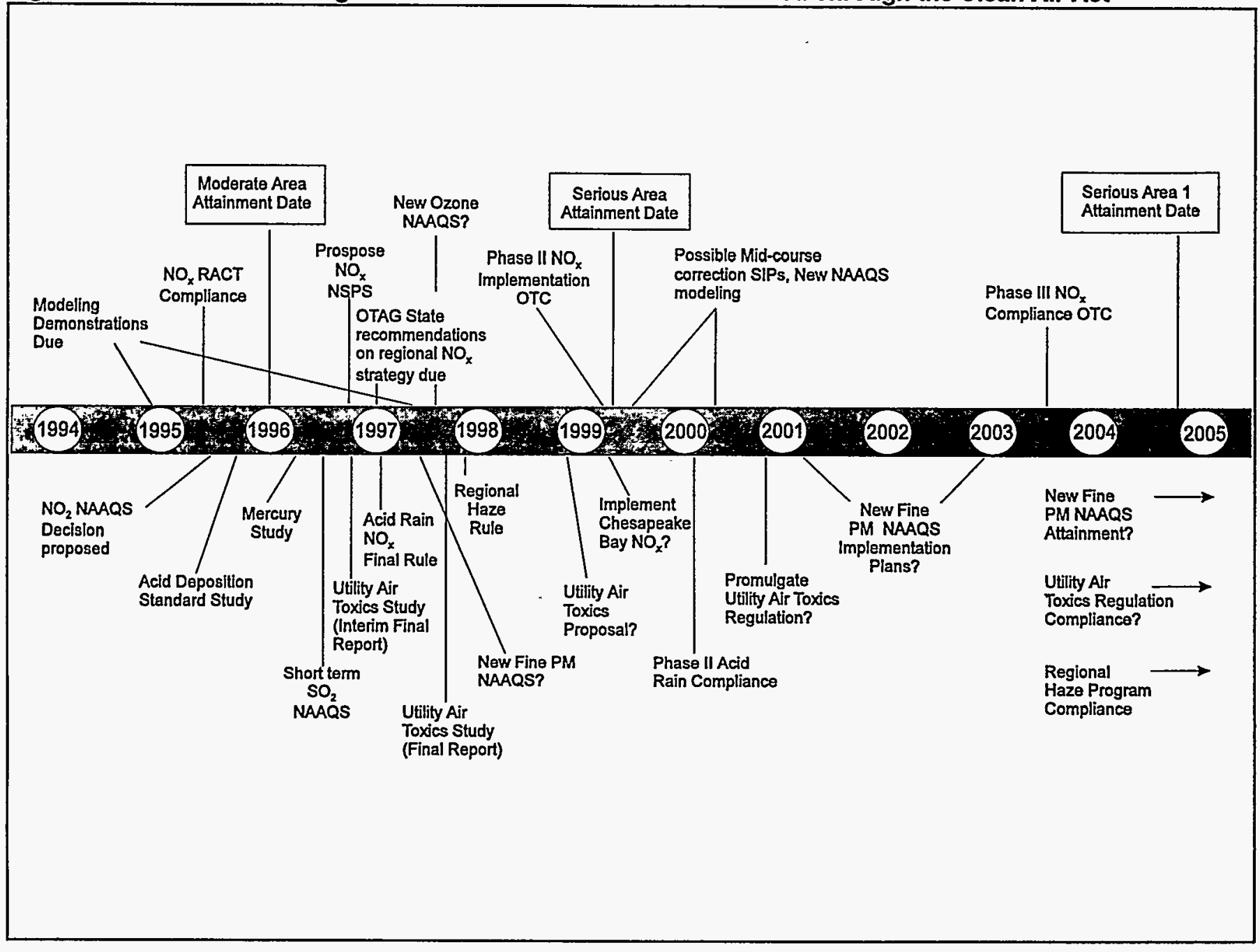

$\mathrm{NO}_{x}=$ Nitrogen oxides.

$\mathrm{SO}_{2}=$ Sulfur dioxide.

$\mathrm{PM}=$ Particulate matter.

$?=$ Under study-possible future regulation.

NAAQS = National Ambient Air Quality Standards.

OTC = Ozone Transportation Commission.

NSR $=$ New Source Review.

OTAG = Ozone Transport Assessment Group.

NSPS $=$ New Source Performance Standards.

RACT = Reasonably Available Control Technology.

SIP = State Implementation Plan.

Source: Environmental Protection Agency, Clean Air Power Initiative Forum, April 1996.

but without the presence of a wet scrubber or a low- $\mathrm{NO}_{x}$ burner, toxic metal emissions may grow.

Synergies resulting from controls to reduce the interaction of $\mathrm{SO}_{2}$ reductions with the regulation of high-volume combustion waste streams are limited. Many of the flue gas treatment processes generate greater levels of bottom and fly ash waste, and, to a certain extent, fuel switching orblending do the same thing. Scrubbing options tend to be less economical because of landfill disposal costs and the need for additional sludge treatment ponds. Some types of coal fuel switching also become less economical based on the amount of ash and slag generated. To reduce disposal costs, some utilities are finding 
commercial uses for wastes, such as gypsum for wall board, roadfill, concrete additives, and fertilizers.

In assessing the control costs of a single pollutant, both the direct costs associated with the control of that pollutant and the indirect costs associated with controlling multiple pollutants should be considered. In addition, the synergistic control effects of particular strategies should be examined. To be cost-effective, utilities choose, if possible, those controls that minimize the total cost of compliance with all pollutant regulations. Regulatory barriers and control uncertainties, however, make the choice of costeffective compliance difficult. Under these circumstances, flexibility is a key component of any utility compliance strategy. CAPI is an attempt to reduce the administrative complexity and break the costly pattern of regulation by providing the power-generation industry with more certainty of future regulatory requirements, greater flexibility, and cost savings. ${ }^{107}$

\section{Utility Compliance Plans on the Internet}

In many cases, utilities are uncertain about their Phase II compliance strategies, and even when utilities are certain, some are less than forthcoming about their plans. The evolution of the industry toward more competition makes some utilities reluctant to discuss their plans because they feel that doing so would erode their competitive edge. A list of some known Phase II compliance strategies can be found on the Internet at the home page of the Energy Information Administration (http://www.eia.doe.gov). Once the connection to the home page has been established, click on "Electricity" in Fuel Groups. A new screen will appear. Scroll down through "Publications" and "Data" to "Applications." Go to the "Clean Air Act Browser" and follow the instructions.

${ }^{107}$ U.S. Environmental Protection Agency, EPA's Clean Air Power Initiative, EPA Number (Washington, DC, April 1996 ), p. 6. 


\section{Conclusion}

The first year of Phase I demonstrated that the new market-based sulfur dioxide emissions control system could achieve significant reductions in emissions at lower than expected costs. The U.S. General Accounting Office has estimated an annual savings of $\$ 2-3$ billion with the market-based system (versus traditional regulation) depending upon the level of allowance trading taking place. Utilities reduced their aggregate emissions far below what was required by law. CAAA90 provided an economic incentive to overcomply, and many utilities seized the opportunity.

The $\$ 2,000$ per ton penalty for noncompliance dwarfed the unexpectedly low prices of sulfur dioxide allowances throughout the first year of Phase I. Many utilities exceeded the required emissions reductions for Phase I through fuel switching and the use of scrubbers, but even those units that emitted more sulfur dioxide than their original allowance allocation would have permitted found it easy to acquire enough allowances to avoid the fine.

More than half of the Phase I plants switched to or blended with lower sulfur coal partially because of the allowance trading program. The allowance trading program helped to create an active coal market in which the delivered price of higher and lower sulfur coal dropped between 1990 and 1995. Other factors contributed to this price reduction, including an oversupply of lower sulfur coal, penetration of competitively priced western lower sulfur coal, and lower transportation costs. Also, utility boiler modifications to burn lower sulfur coal were less expensive than predicted. The tendency for utilities to purchase lower sulfur coal may have resulted in early reduction of sulfur dioxide emissions and more allowance credits earned.

The evolution of the electric power industry toward more competition has led utilities to delay capital expenditures for pollution çontrol equipment as long as possible. Phase II emissions requirements are more stringent and affect many more generating units than those of Phase I. Utilities are reluctant to make commitments for Phase II because of competition and uncertainty about possible future regulatory requirements. Utility Phase I allowances are estimated to last until 2005. Utilities will have to reduce emissions to meet the more stringent Phase II requirements, and scrubbers and repowering most likely will be more attractive options than they are currently. 

Appendix A

Federal Legislation To Control Air Pollution 



\section{Appendix A}

\section{Federal Legislation To Control Air Pollution}

Federal legislative efforts aimed at controlling air pollution in the United States began in the mid-1950's when Congress passed an act requiring the provision of research and technical assistance relating to air pollution control to the States. Since then, the Federal role in air pollution control has grown considerably, and today the Federal Government sets national emissions standards for specific air pollutants. It also monitors industry's compliance with these standards.
The Clean Air Act Amendments of 1990 is the latest air pollution control legislation enacted by the U.S. Congress. Other Federal legislation controlling air pollution includes the Clean Air Act of 1963, the Air Quality Act of 1967, the Clean Air Act Amendments of 1970 and 1977, and various additional amendments and extensions of the Clean Air Act passed in 1971, 1973, 1974, and 1976 (Table A1).

Table A1. Chronology of Historic Federal Legislation To Control Air Pollution

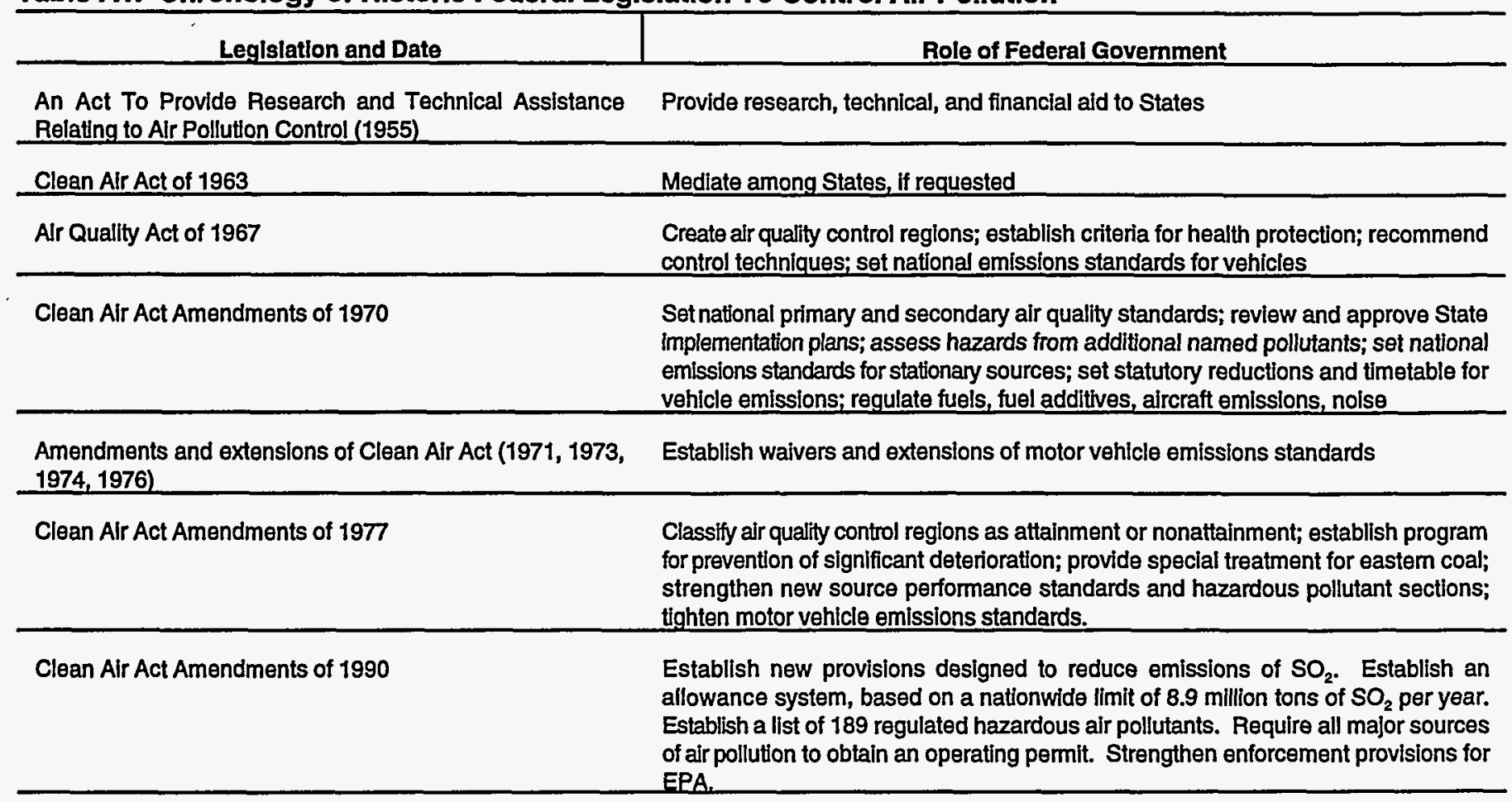

Sources: Lester B. Lave and Gilbert S. Omenn, Clearing the Air: Reforming the Clean Air Act (Washington, DC: Brookings Institution, 1981), p. 6. Environmental Law Institute, Clean Air Deskbook (Washington DC, March 1992) and Clean Air Act Handbook, A Practical Guide to Compliance, Third Edition, 1993. 


\section{An Act To Provide Research and Technical Assistance Relating to Air Pollution Control}

Passed in 1955, an Act To Provide Research and Technical Assistance Relating to Air Pollution Control was, in part, a response to the growing concentration of the U.S. population in urban areas, many of which were spread over more than one State (e.g., New York, Chicago, and Washington, D.C.). Congress found that "the growth in the amount and complexity of air pollution brought about by urbanization, industrial development, and the increasing use of motor vehicles, had resulted in mounting dangers to the public's health and welfare, including injury to agricultural crops and livestock, damage to and the deterioration of property, and hazards to air and ground transportation."

The 1955 act sought to remedy the growing air pollution problem by supporting research and providing information and financial aid to the States. The act expressly acknowledged the primary responsibilities and rights of State and local governments to control air pollution. The Federal Government had no direct regulatory role.

\section{The Clean Air Act of 1963}

The Clean Air Act of 1963 began to expand the role of the Federal Government in curbing air pollution by including direct regulation. Air pollution that "endangered the health or welfare of any persons" was made "subject to abatement" under certain circumstances. The law provided two additional tools for use in the fight against air pollution. Federal funds were to be made available to State and local pollution-control agencies, and, because the effects of air pollution often crossed State boundaries, the negotiation of interstate compacts establishing joint control agencies was authorized.

\section{The Air Quality Act of 1967}

The Air Quality Act of 1967 further extended the role of the Federal Government into air pollution standards. It authorized the Secretary of Health, Education, and Welfare to create air quality regions and establish criteria for setting air quality levels that would protect public health. The States were required to adopt ambient air quality standards consistent with these criteria.

\section{The Clean Air Act Amendments of $\mathbf{1 9 7 0}$}

The Clean Air Act Amendments of 1970 substantially expanded the Federal role in air pollution control. The act came about because, with the exception of California,
State and local governments had taken only limited action to control air pollution. Congress decided that the National Ambient Air Quality Standards (NAAQS) were the appropriate criteria for protecting public health, and it dismissed the relevance of abatement cost in setting the standards. The newly created Environmental Protection Agency (EPA) was given responsibility for setting the standards. The States implemented the program by designing, seeking EPA approval for, and then enforcing State Implementation Plans that would ensure attainment of the NAAQS by 1975. Standards were promulgated for 6 criteria pollutants: particulate matter, sulfur oxides, carbon monoxide, nitrogen dioxide, ozone, and nonmethane hydrocarbons. A standard for lead was added in 1978 , and the standard for ozone was revised in 1979. All of these standards are still in place.

For enforcement purposes, the United States was divided into 274 air quality control regions. NAAQS limits were required to be met in each region. Control regions within State boundaries where the ambient pollutant concentrations were below or met the NAAQS were designated as "attainment areas" by the 1970 amendments. Conversely, areas where the ambient pollutant concentrations did not meet NAAQS were labeled "nonattainment areas."

Distinct from ambient standards, the 1970 amendments also introduced national emissions standards for new stationary sources of air pollution, limiting the amounts of sulfur dioxide $\left(\mathrm{SO}_{2}\right)$, nitrogen oxides $\left(\mathrm{NO}_{x}\right)$, and particulates that coal-fired boilers of certain classes could emit. In general, these technology-based standards called for the application of the "best available control technology," under which Congress did allow some consideration of the cost of the abatement. However, Congress imposed stringent deadlines for achieving national standards.

\section{The Clean Air Act Amendments of 1977}

The Clean Air Act Amendments of 1977 further emphasized the classification of air quality control regions as attainment or nonattainment areas with regard to all established ambient air standards. Sanctions and special implementation strategies were introduced for nonattainment areas. The amendments stipulated that sources in nonattainment areas must use "reasonably available pollution control technologies," taking into consideration both cost and technological feasibility.

The amendments also imposed new requirements on areas already in attainment. The concept of prevention of significant deterioration (PSD) was introduced whereby 
the amendments established specific increments for maximum allowable increases in ambient concentrations for three classes of PSD areas. The PSD program included a permit program for new major emission sources and modifications to existing sources. It required sources to apply "best available technology," which would be determined case by case.

\section{The Clean Air Act Amendments of 1990}

The 1990 amendments establish a list of 189 regulated hazardous air pollutants. EPA is required to establish standards for major sources, which are defined as those with the potential to emit 10 tons per year of any single hazardous pollutant or 25 tons of any combination of pollutants.

The amendments establish a new permit program whereby all major sources are required to obtain an operating permit. States with approved permitting programs issue permits, but EPA has the power to veto State permits. Citizens also have certain rights to challenge State permits.

The 1990 amendments also establish the Acid Rain Program, which is designed to reduce the adverse effects of acid deposition. This improvement will be achieved primarily through reductions of $\mathrm{SO}_{2}$ and $\mathrm{NQ}_{4}$ emissions by electricity producers, while concurrently encouraging energy conservation and the use of renewable and clean alternative technologies in electricity production. The primary goal of the Acid Rain Program, which will be nstituted in 2010, is to reduce annual $\mathrm{SO}_{2}$ emissions from electric utilities to a level that is 10 million tons below the 1980 level. Emission allowances serve as the mechanism for compliance. Each affected unit is allocated its allowances based on its baseline fuel consumption. The baseline is calculated from the average yearly fuel consumption for the period 1985-1987. In Phase I, allowances are allocated at the rate of 2.5 pounds of $\mathrm{SO}_{2}$ times the number of mmBtu consumed in the baseline. In Phase II, allowances are allocated at the rate of 1.2 pounds of $\mathrm{SO}_{2}$ times the number of $\mathrm{mmBtu}$ consumed in the baseline.

The legislation also requires a reduction of 2 million tons of $\mathrm{NO}_{\mathrm{x}}$ emissions from utility boilers. Utilities were required to apply low- $\mathrm{NO}_{\mathrm{x}}$-burner technologies to meet regulations that become effective on the date the unit must meet the $\mathrm{SO}_{2}$ standard, i.e., January 1,1995 , for Phase I units; January 1, 1997, for Phase I units employing scrubber technology; and January 1, 2000, for all Phase II units. However, a lawsuit pushed the date of compliance back to January 1, 1996, for the Phase I units that had been required to be in compliance on January $1,1995 . \mathrm{NO}_{\mathrm{x}}$ limits for dry-bottom, wall-fired and tangentially fired boilers affected in Phase I have been selected as 0.50 pounds per million Btu and 0.45 pounds per million Btu, respectively. Regarding Phase II compliance, $\mathrm{NO}_{\mathbf{x}}$ limits must be established by no later than January 1,1997 , for two categories of boilers exempted from Phase I: cell- and cyclone-fired units. Also by that date, the limits for drybottom, wall-fired and tangentially fired boilers can be revised, if EPA deems it feasible with new technology. An emissions averaging provision allows individual utilities to average $\mathrm{NO}_{\mathrm{x}}$ emissions over multiple units, if the same or lower emissions result. 

Appendix B

Profiles of the 261 Table 1

Generators Affected by Phase I (Table B1) and a Profile of the Coal Received at Table 1 Plants (Table B2) 


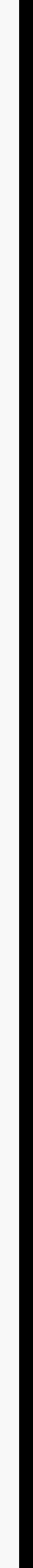




\section{Appendix B}

\section{Profiles of the 261 Table 1 Generators Affected by Phase I (Table B1) and a Profile of the Coal Received at Table 1 Plants (Table B2)}

Table B1 presents detailed information about the 261 Table 1 generator units affected by Phase I of the Clean Air Act Amendments of 1990 and the 174 substitution and compensating generator units associated with them. The table is organized around those generators that were explicitly named in the legislation as Table 1 units. The substitution and compensating units are listed to the right of each Table 1 unit.

Capacities and annual Phase I allowance allocations are provided along with 1985 sulfur dioxide $\left(\mathrm{SO}_{2}\right)$ emissions estimates and $1995 \mathrm{SO}_{2}$ emissions as determined by continuous emissions monitors (CEMS). Compliance methods and ages are also provided for the 261 Table 1 generators.

For each associated substitution and compensating unit, $1985 \mathrm{SO}_{2}$ emissions estimates and $1995 \mathrm{SO}_{2}$ emissions as determined by CEMS are provided.

Table B2 shows the origin, quality, and delivered price of coal received at the Table 1 plants in 1995. 

Table B1. Proflle of the 261 Table 1 Generators Affected by Phase I

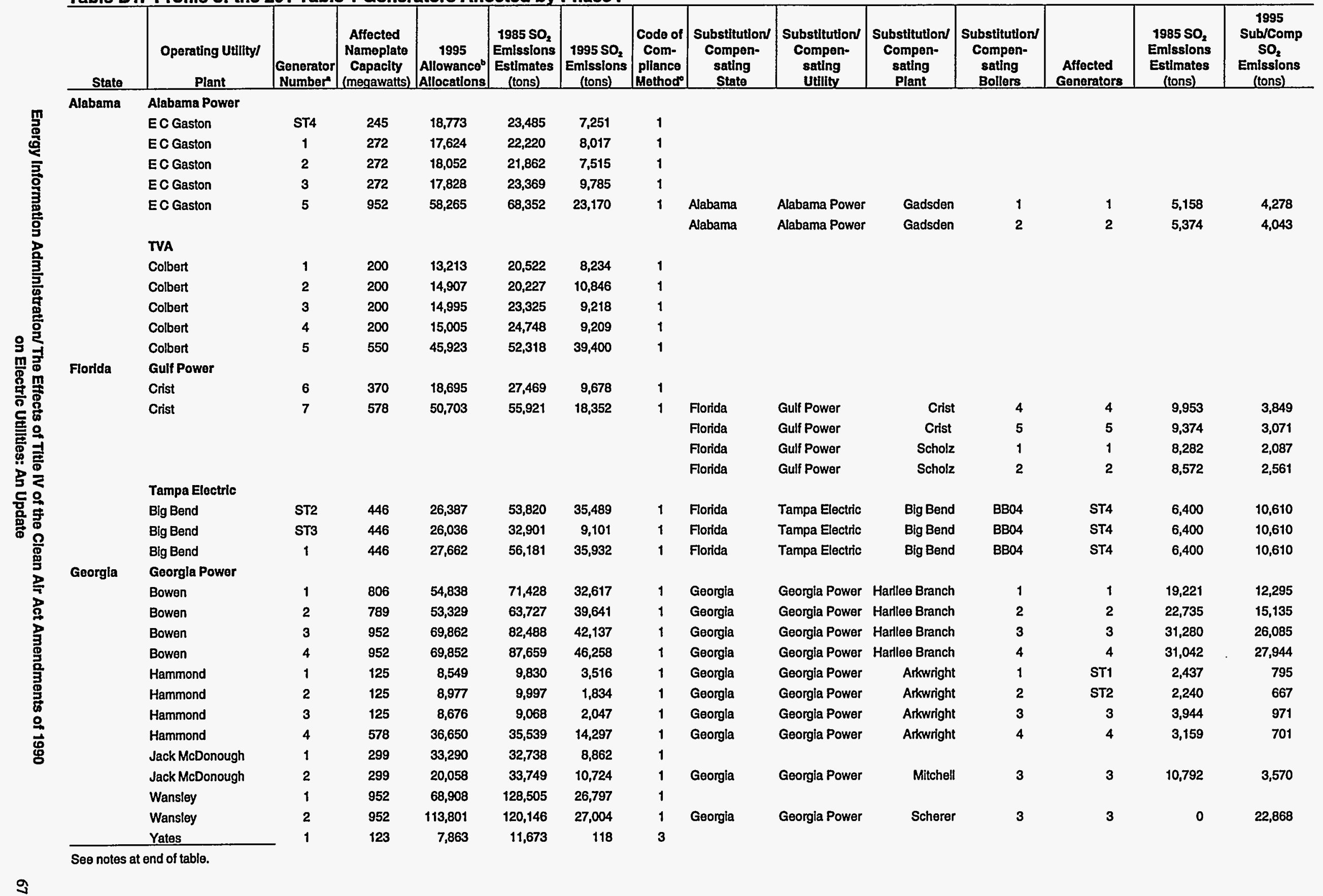


Table B1. Profile of the 261 Table 1 Generators Affected by Phase I (Continued)

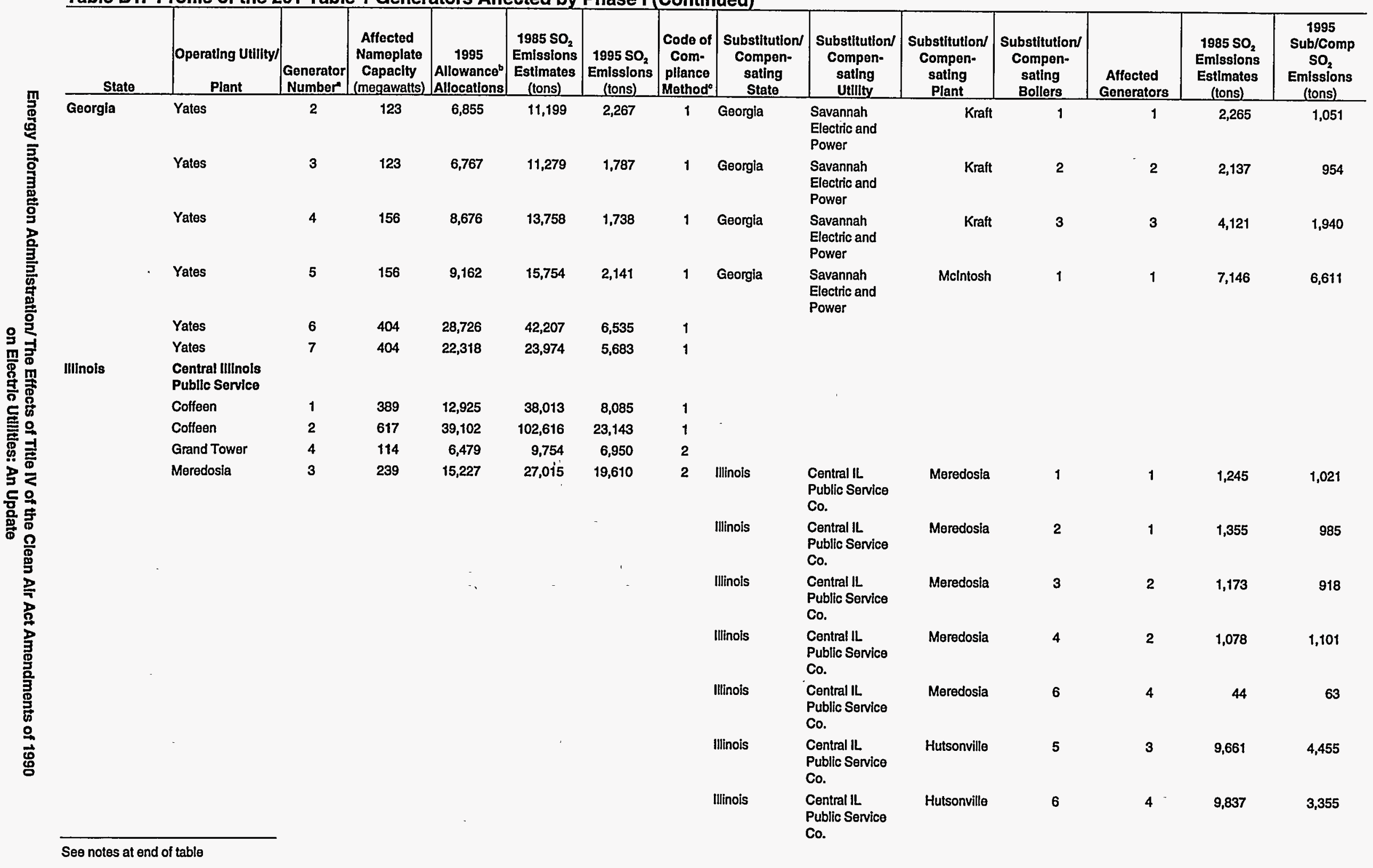


Table B1. Profile of the 261 Table 1 Generators Affected by Phase I (Continued)

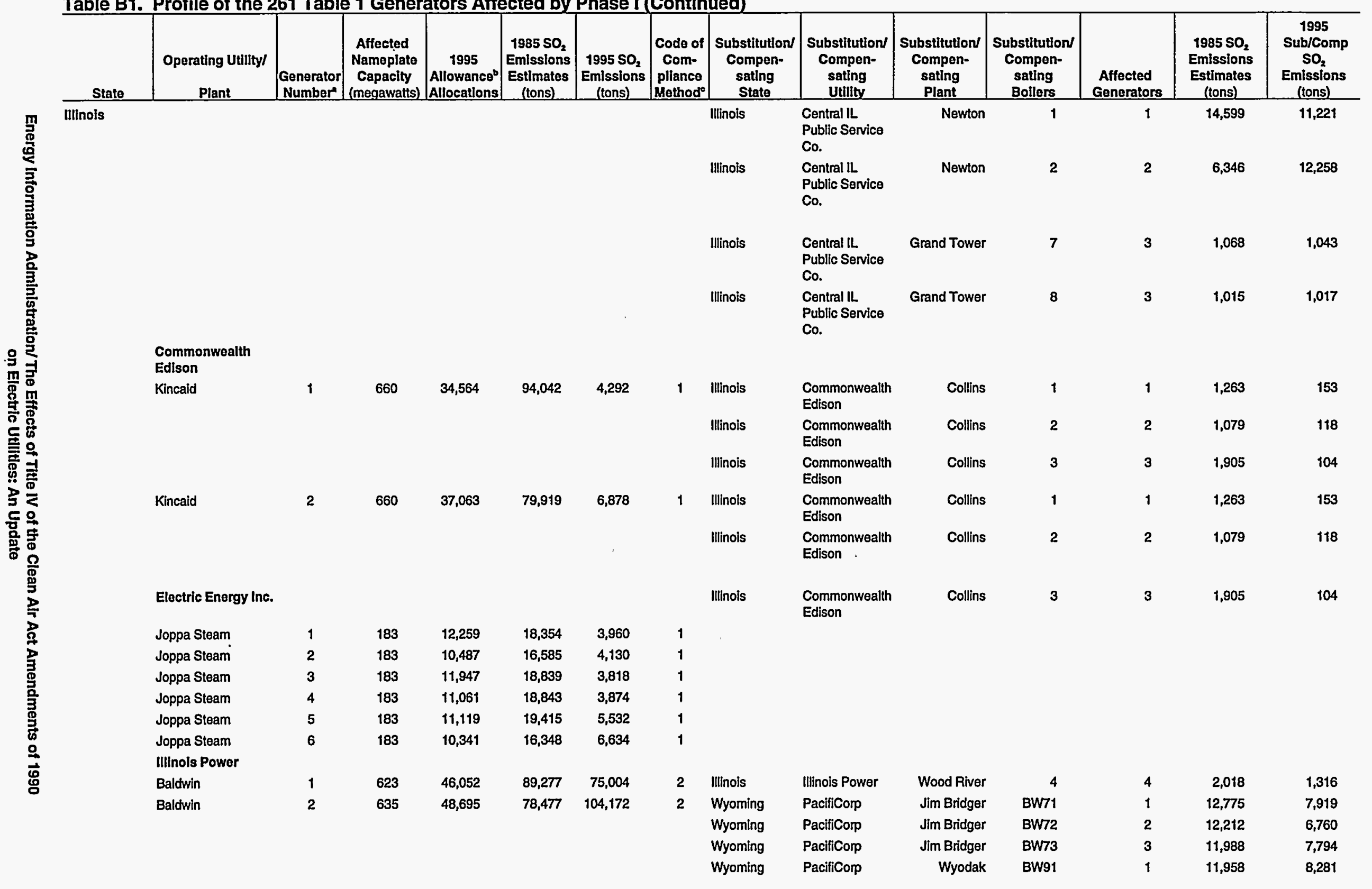


Table B1. Profile of the 261 Table 1 Generators Affected by Phase I (Continued)

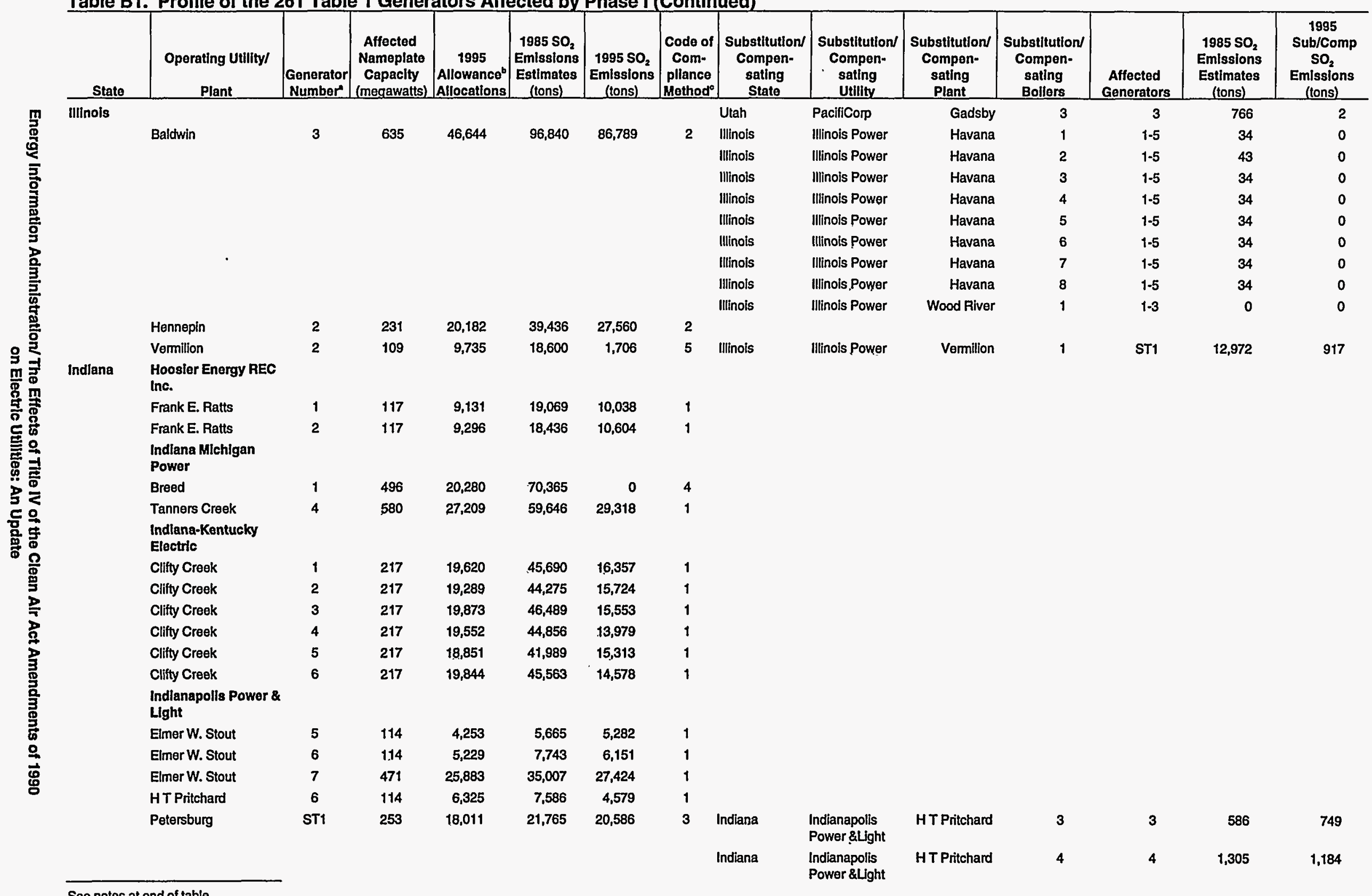


Table B1. Profile of the 261 Table 1 Generators Affected by Phase I (Continued)

\begin{tabular}{|c|c|c|c|c|c|c|c|c|c|c|c|c|c|c|}
\hline \multirow{9}{*}{$\underset{\mathrm{\Phi}}{\mathrm{S}} \frac{\text { State }}{\text { Indlana }}$} & $\begin{array}{c}\text { Operating Utilityl } \\
\text { Plant }\end{array}$ & $\begin{array}{c}\text { Generator } \\
\text { Number }\end{array}$ & $\begin{array}{c}\text { Affected } \\
\text { Nameplate } \\
\text { Capacity } \\
\text { (megawatts) }\end{array}$ & $\begin{array}{c}1995 \\
\text { Allowance } \\
\text { Allocations }\end{array}$ & $\begin{array}{c}1985 \mathrm{SO}_{2} \\
\text { Emissions } \\
\text { Estimates } \\
\text { (tons) }\end{array}$ & $\begin{array}{c}1995 \mathrm{SO}_{2} \\
\text { Emlssions } \\
\text { (tons) }\end{array}$ & $\begin{array}{c}\text { Code of } \\
\text { Com- } \\
\text { pllance } \\
\text { Method }\end{array}$ & $\begin{array}{c}\text { Substitution/ } \\
\text { Compen- } \\
\text { sating } \\
\text { State }\end{array}$ & $\begin{array}{c}\text { Substitution } \\
\text { Compen- } \\
\text { sating } \\
\text { Utility }\end{array}$ & $\begin{array}{c}\text { Substitution } \\
\text { Compen- } \\
\text { sating } \\
\text { Plant }\end{array}$ & $\begin{array}{c}\text { Substitution } \\
\text { Compon- } \\
\text { sating } \\
\text { Bollers } \\
\end{array}$ & $\begin{array}{c}\text { Affected } \\
\text { Generators } \\
\end{array}$ & $\begin{array}{c}1985 \mathrm{SO}_{2} \\
\text { Emissions } \\
\text { Estimates } \\
\text { (tons) } \\
\end{array}$ & $\begin{array}{c}1995 \\
\text { Sub/Comp } \\
\text { SO }_{2} \\
\text { Emissions } \\
\text { (tons) }\end{array}$ \\
\hline & & & & & & & & Indiana & $\begin{array}{l}\text { Indianapolis } \\
\text { Power \&Light }\end{array}$ & HT Pritchard & 5 & 5 & 1,458 & 1,353 \\
\hline & & & & & & & & Indiana & $\begin{array}{l}\text { Indianapolis } \\
\text { Power \&Light }\end{array}$ & Petersburg & 3 & ST3 & 15,471 & 20,479 \\
\hline & & & & & & & & Indiana & $\begin{array}{l}\text { Indianapolis } \\
\text { Power \&Light }\end{array}$ & Petersburg & 4 & 4 & 12,864 & 21,041 \\
\hline & Petersburg & ST2 & 471 & 35,496 & 53,110 & 42,075 & 3 & Indiana & $\begin{array}{l}\text { Indianapolis } \\
\text { Power \&Light }\end{array}$ & HT Pritchard & 3 & 3 & 15,471 & 749 \\
\hline & & & & & & & & Indiana & $\begin{array}{l}\text { Indianapolis } \\
\text { Power \&Light }\end{array}$ & HT Pritchard & 4 & 4 & 12,864 & 1,184 \\
\hline & & & & & & & & Indiana & $\begin{array}{l}\text { Indianapolis } \\
\text { Power \&Light }\end{array}$ & HT Pritchard & 5 & 5 & 1,458 & 1,353 \\
\hline & & . & & & & & & Indiana & $\begin{array}{l}\text { Indianapolis } \\
\text { Power \&Light }\end{array}$ & Petersburg & 3 & ST3 & 15,471 & 20,479 \\
\hline & Northern Indiana & & & & & & & Indiana & $\begin{array}{l}\text { Indianapolis } \\
\text { Power \&Light }\end{array}$ & Petersburg & 4 & 4 & 12,864 & 21,041 \\
\hline
\end{tabular}

Northern Indiana

Bailly

Michigan City

PSI Energy

Cayuga

Cayuga

Gibson

Gibson

Gibson

Gibson

R Gallagher

R Gallagher

R Gallagher

R Gallagher

Wabash River

Wabash River

Wabash River

Wabash River

Wabash River

See notes at end of table.

$\begin{array}{rrrrr}194 & 30,088 & 26,874 & 2,307 & 3 \\ 422 & 39,951 & 12,312 & 3,938 & 3 \\ 540 & 48,963 & 45,434 & 12,261 & 1 \\ & & & & \\ 531 & 47,631 & 56,848 & 44,666 & 1 \\ 531 & 40,579 & 69,254 & 46,504 & 1 \\ 668 & 44,288 & 71,467 & 51,701 & 2 \\ 668 & 44,956 & 77,864 & 48,279 & 2 \\ 668 & 45,033 & 67,787 & 60,912 & 2 \\ 668 & 64,632 & 77,551 & 3,783 & 3 \\ 150 & 13,908 & 1,770 & 13,127 & 2 \\ 150 & 12,644 & 19,178 & 12,266 & 2 \\ 150 & 13,127 & 20,883 & 11,766 & 2 \\ 150 & 12,512 & 21,980 & 14,471 & 2 \\ 113 & 5,558 & 6,713 & 197 & 5 \\ 113 & 5,874 & 6,308 & 2,867 & 2 \\ 123 & 4,111 & 6,889 & 3,149 & 2 \\ 125 & 4,838 & 8,201 & 2,615 & 2 \\ 387 & 17,362 & 26,239 & 13,902 & 2\end{array}$


Table B1. Profile of the 261 Table 1 Generators Affected by Phase I (Continued)

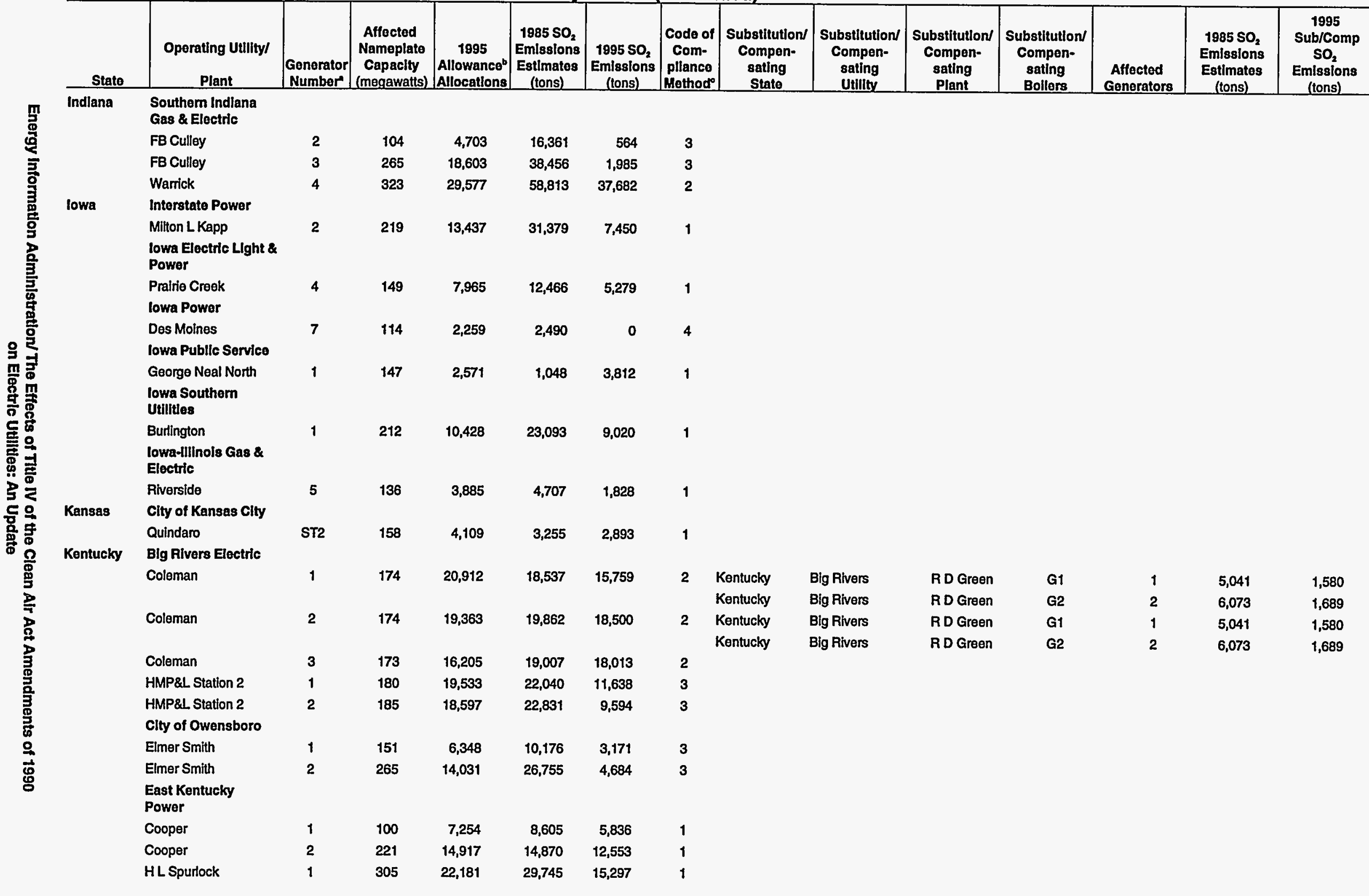

See notes at end of table 
Table B1. Profile of the 261 Table 1 Generators Affected by Phase I (Continued)

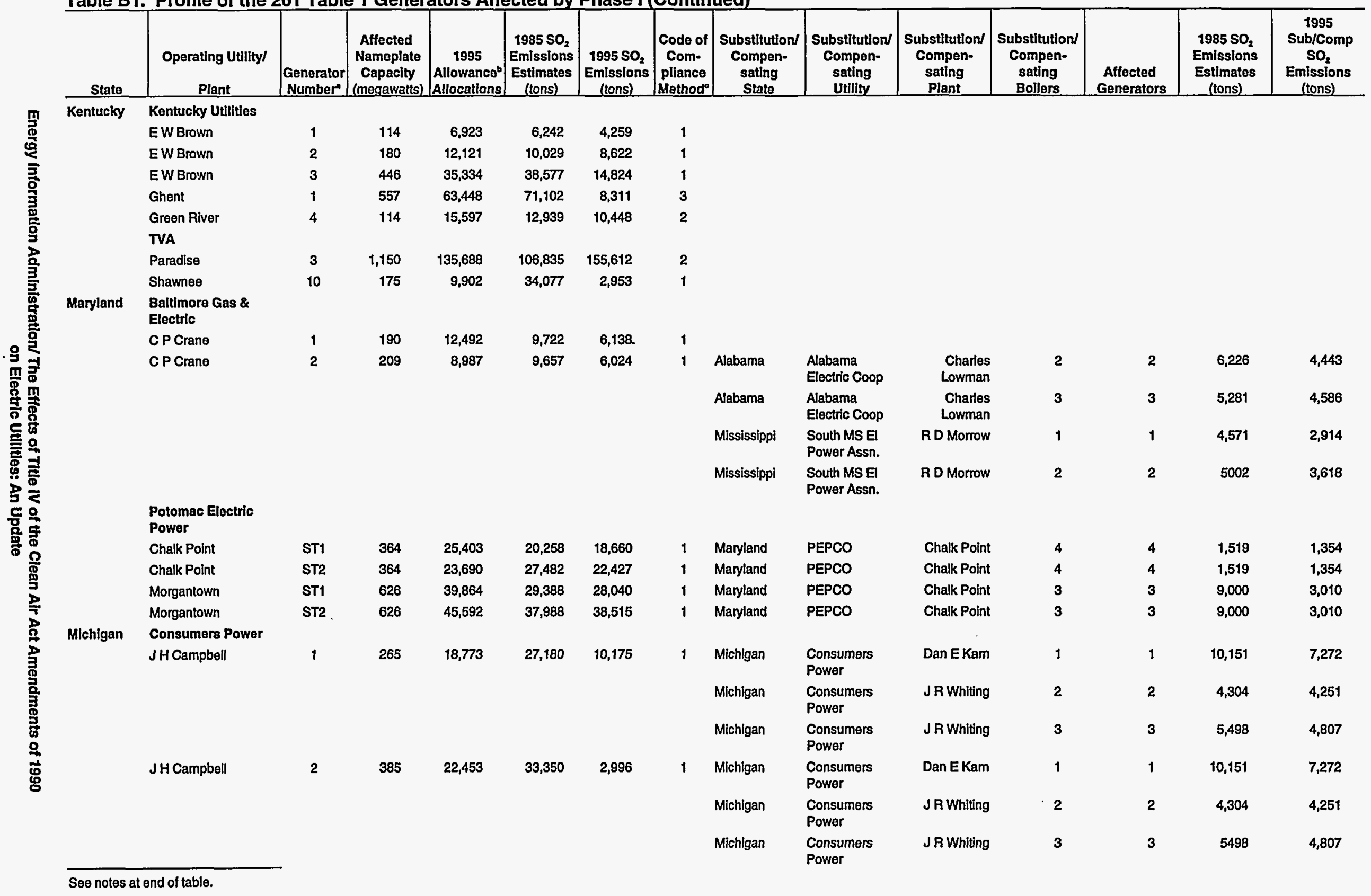


Table B1. Profile of the 261 Table 1 Generators Affected by Phase I (Continued)

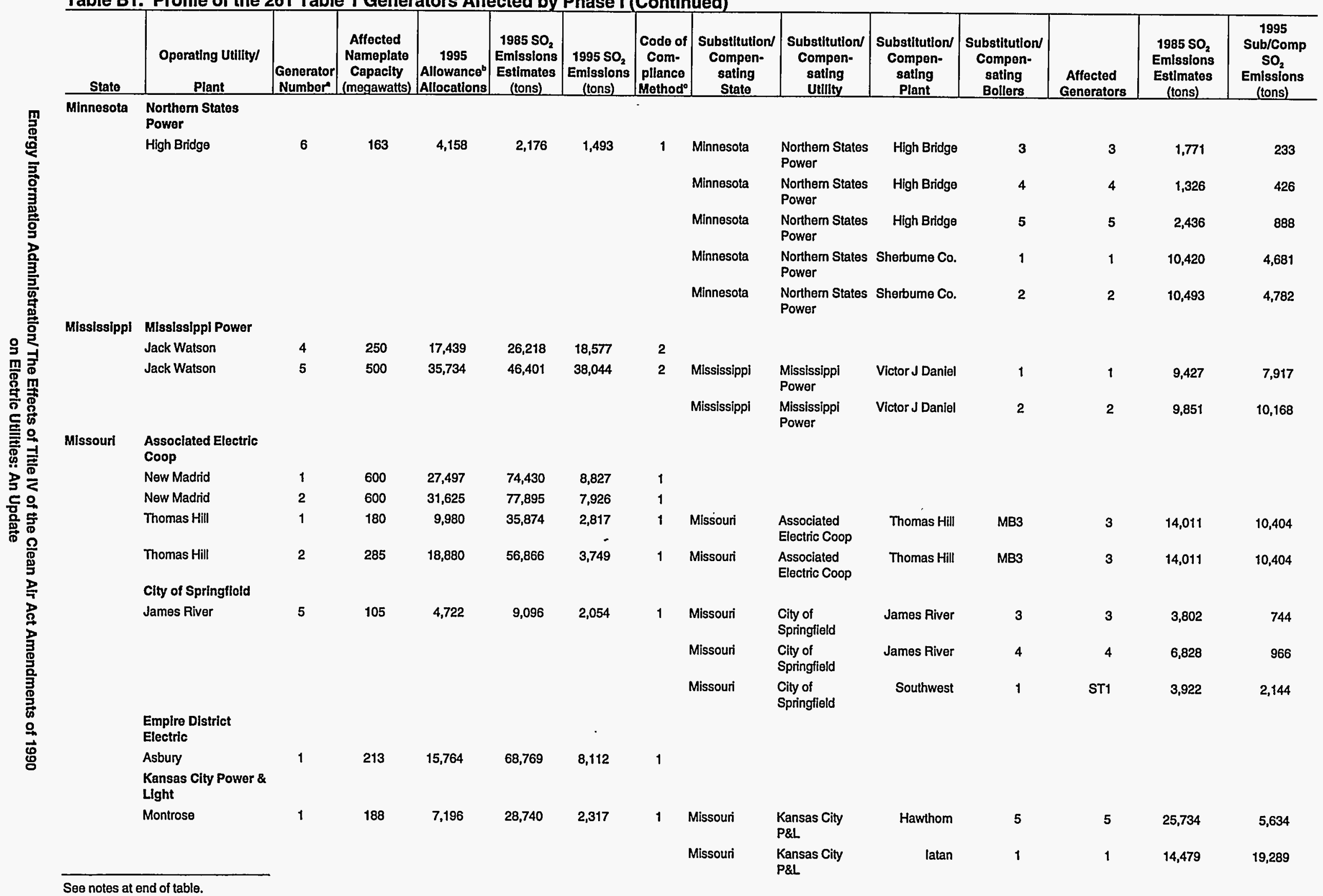


Table B1. Profile of the 261 Table 1 Generators Affected by Phase 1 (Continued)

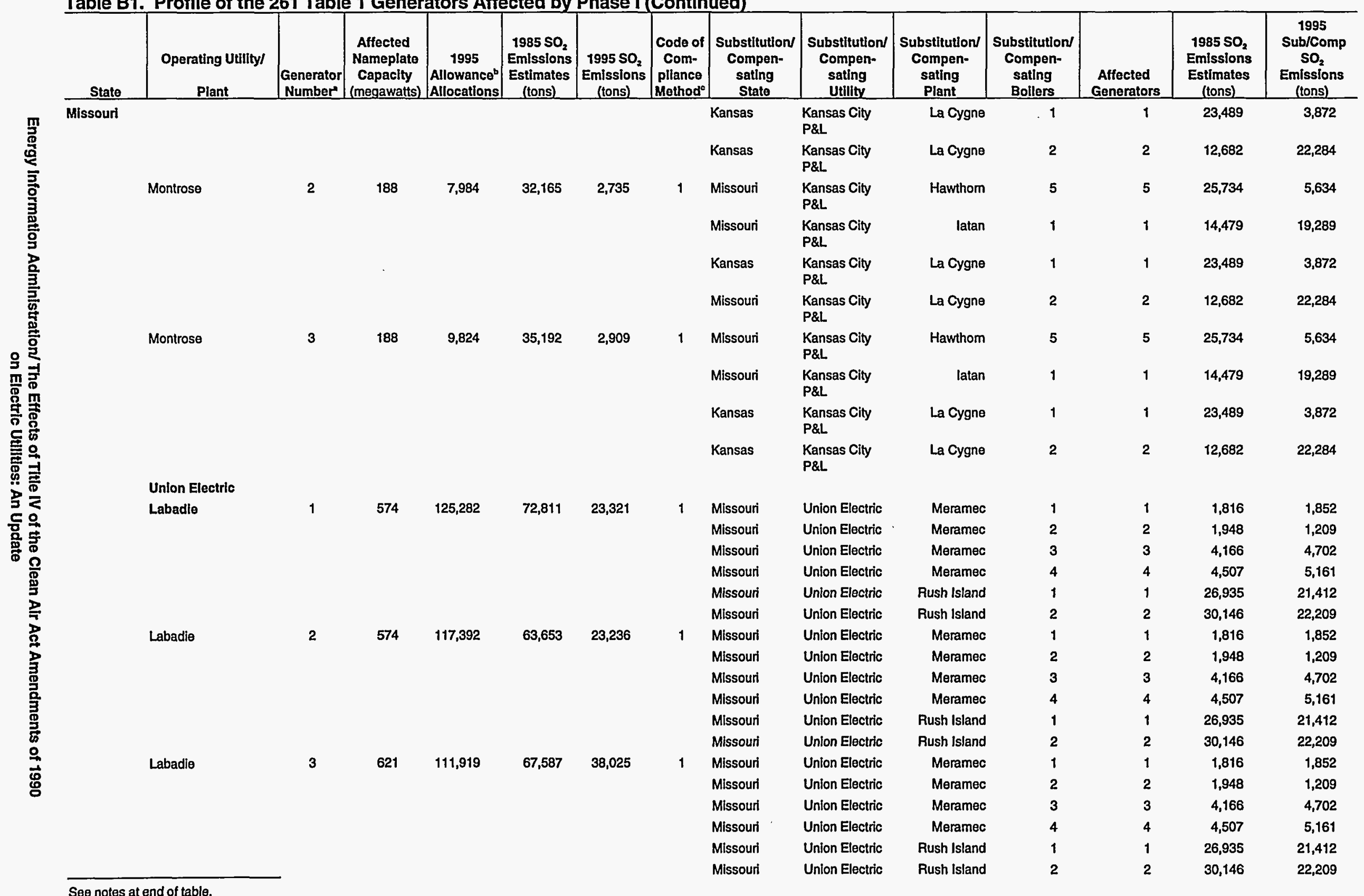




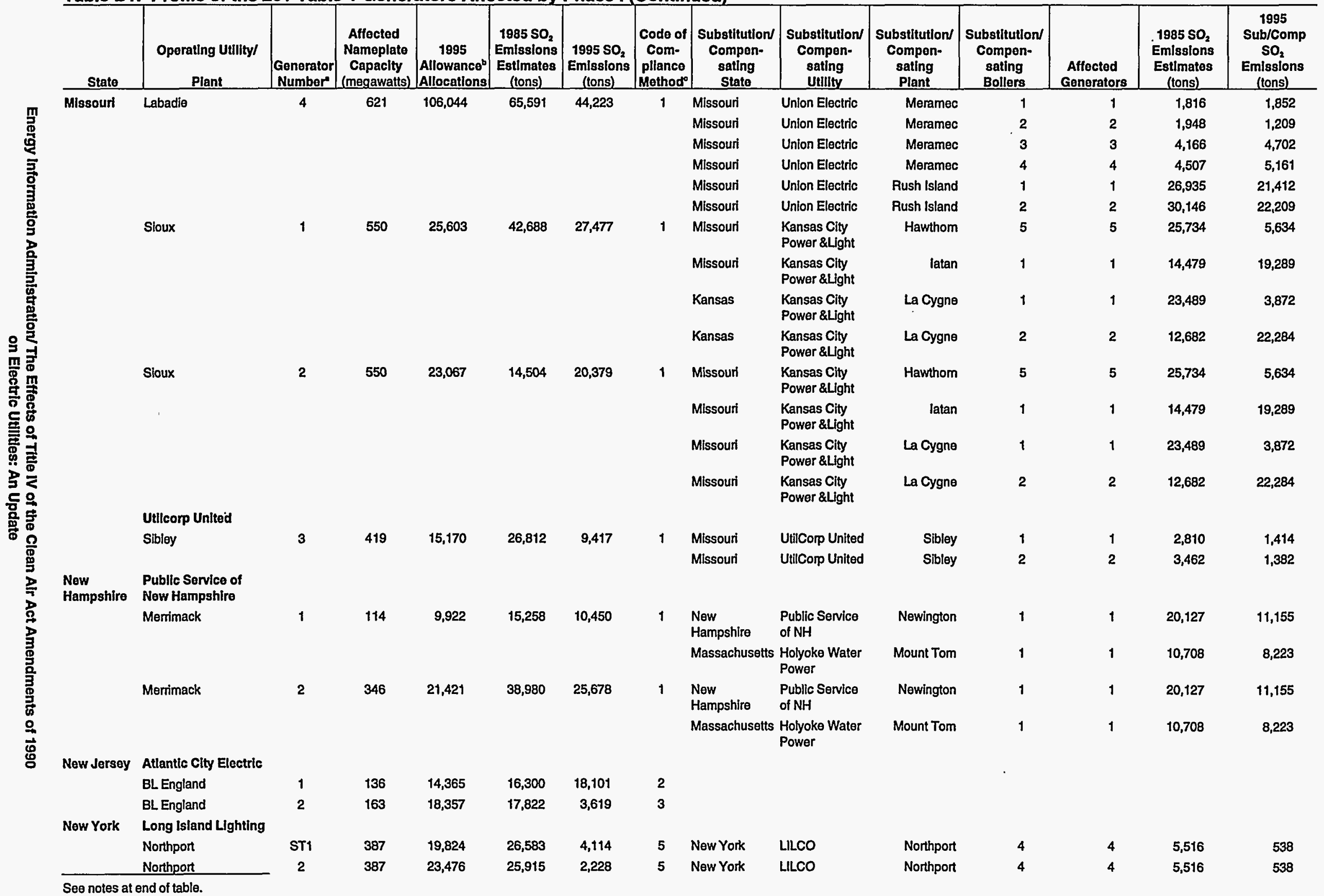


Table B1. Profile of the 261 Table 1 Generators Affected by Phase I (Continued)

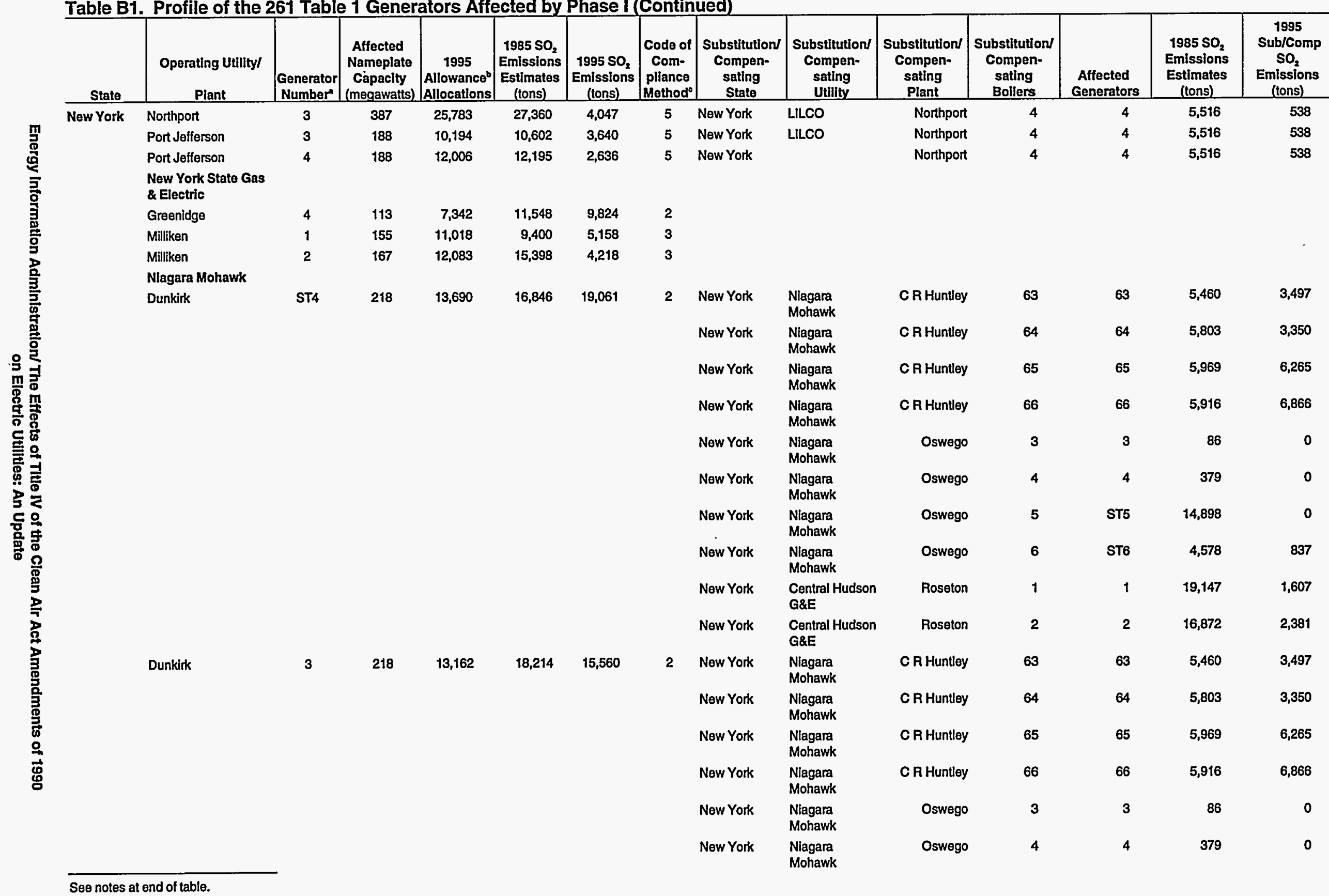


Table B1. Profile of the 261 Table 1 Generators Affected by Phase I (Continued)

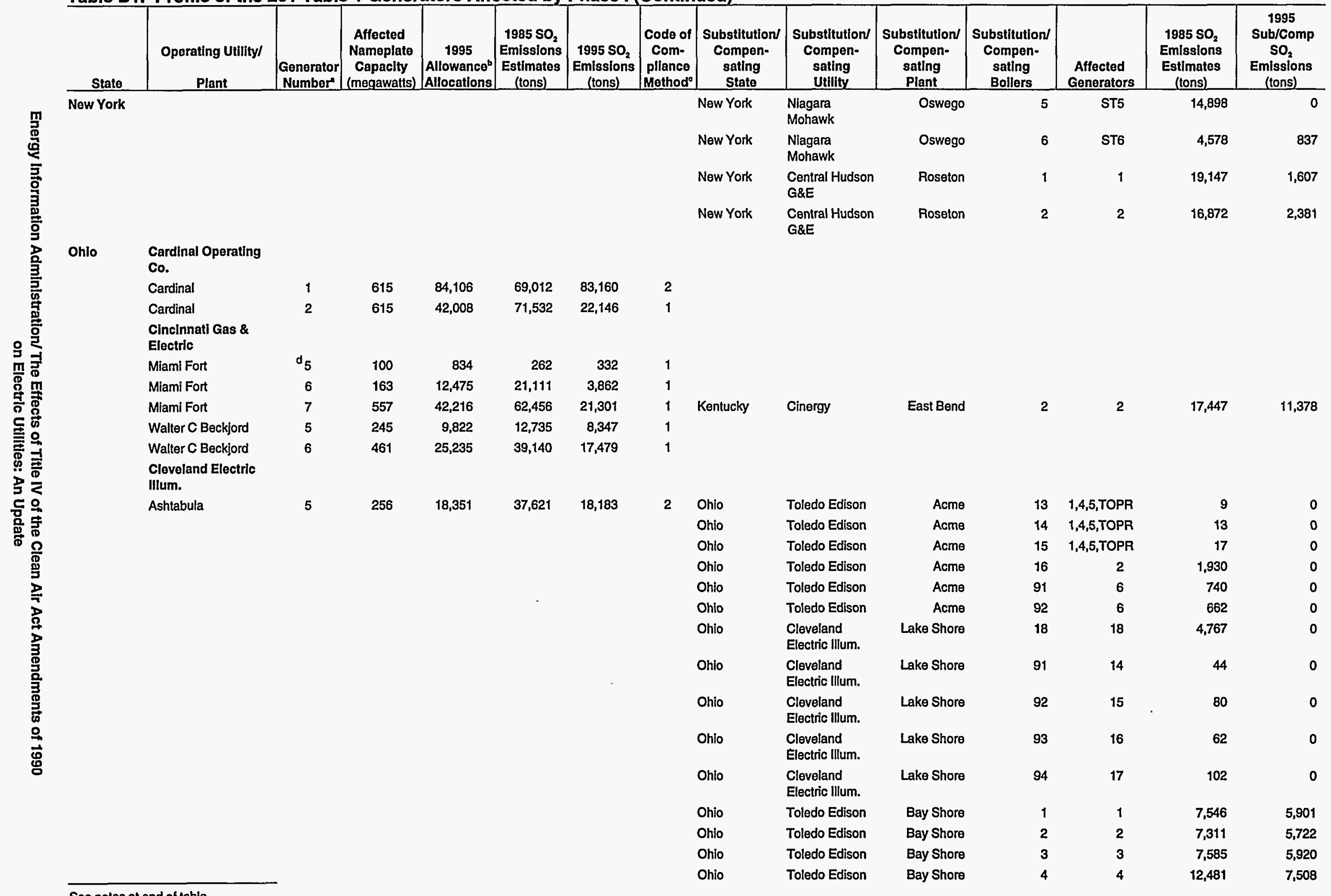


Table B1. Profile of the 261 Table 1 Generators Affected by Phase I (Continued)

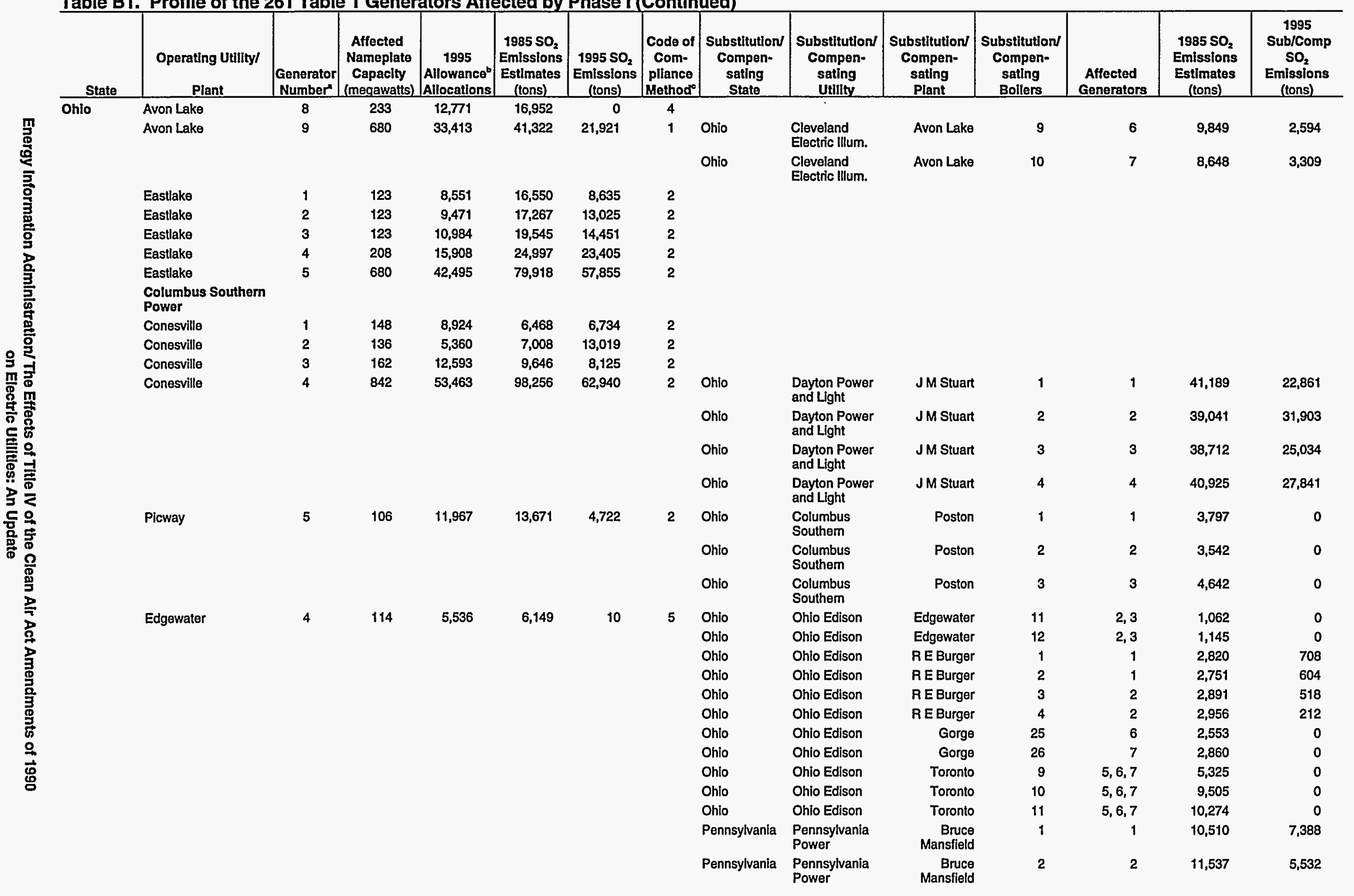

ปี See notes at end of table. 
Table B1. Profile of the 261 Table 1 Generators Affected by Phase I (Continued)

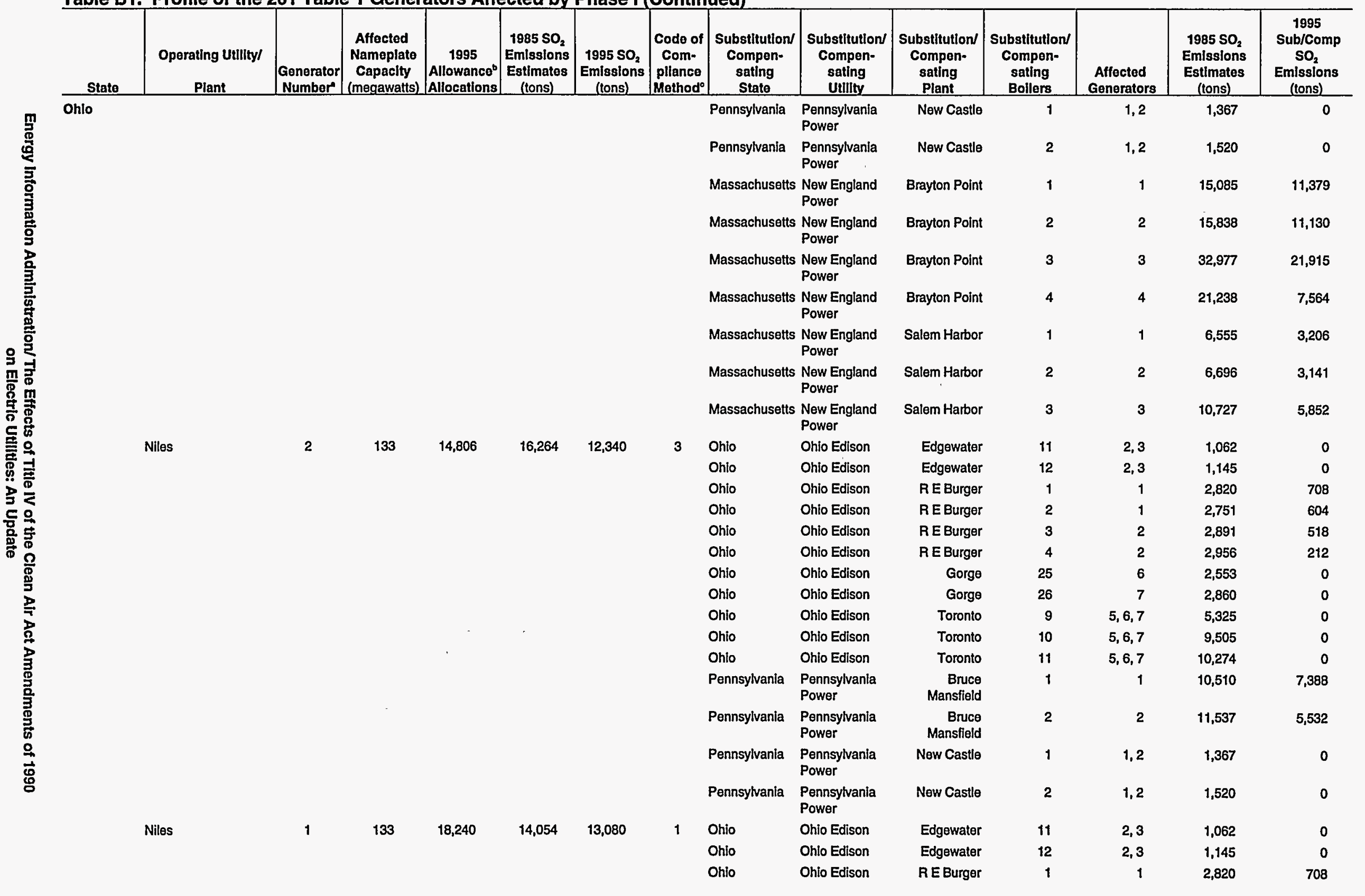


Table B1. Profile of the 261 Table 1 Generators Affected by Phase I (Continued)

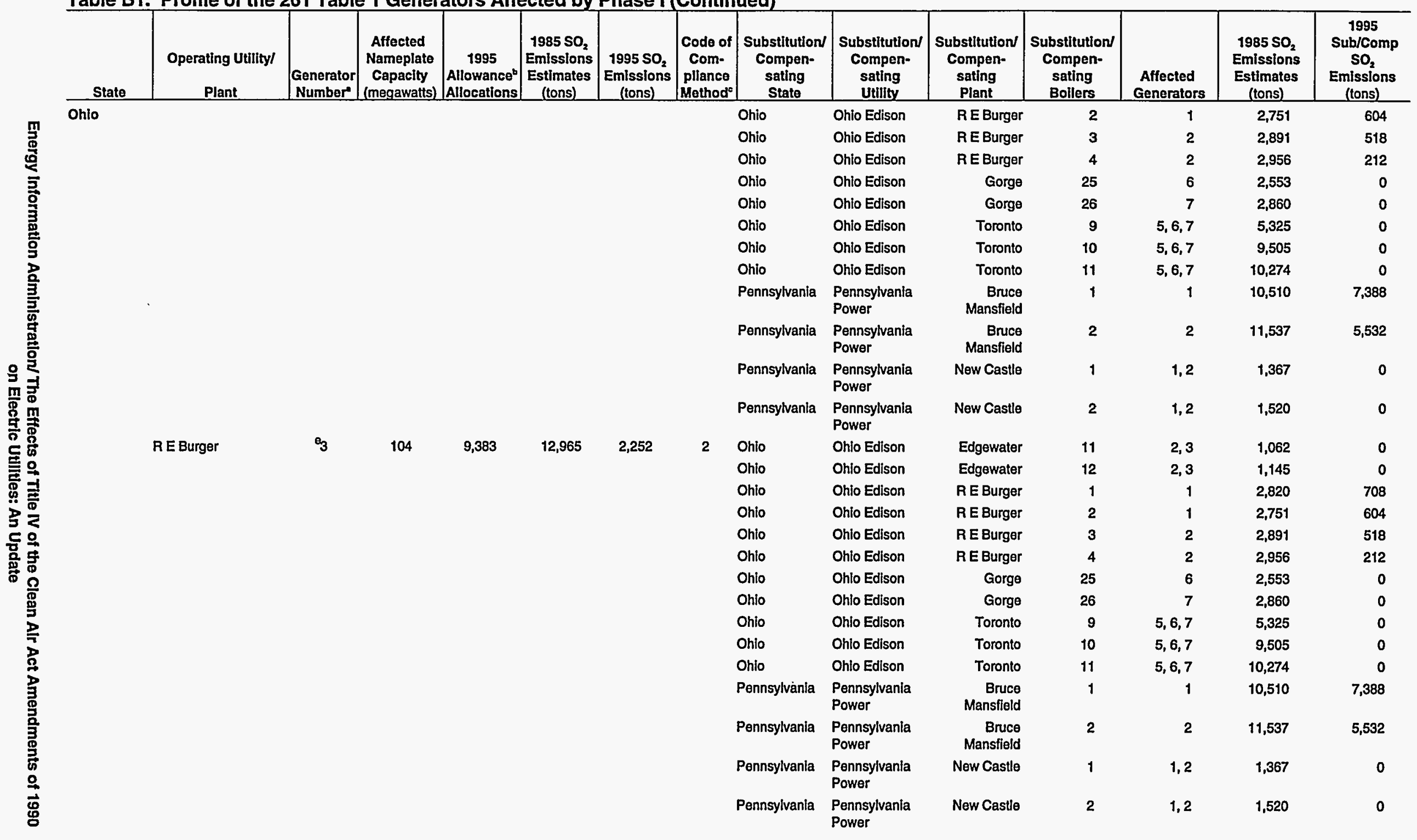


Table B1. Profile of the 261 Table 1 Generators Affected by Phase I (Continued)

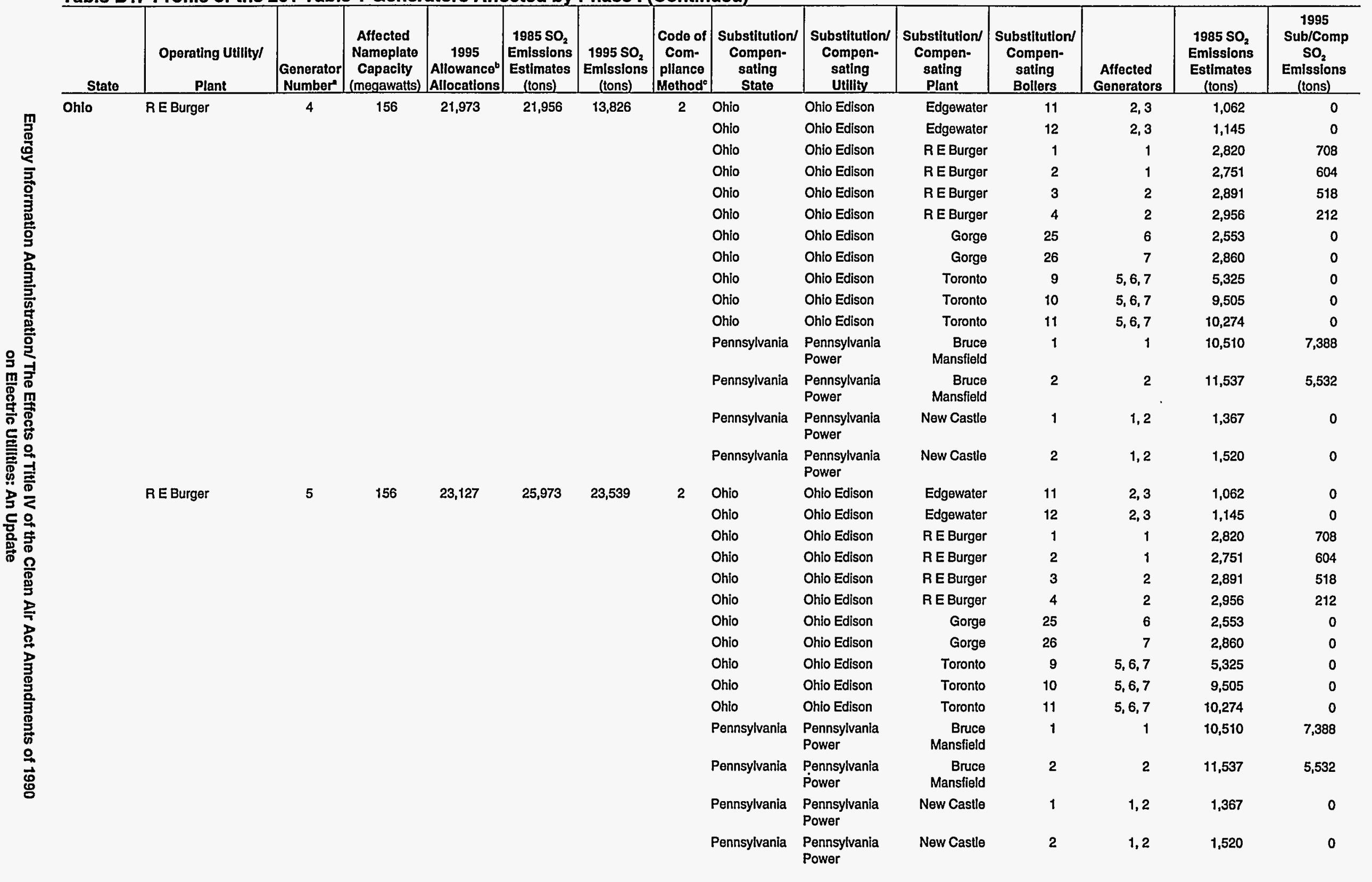


Table B1. Profile of the 261 Table 1 Generators Affected by Phase I (Continued)

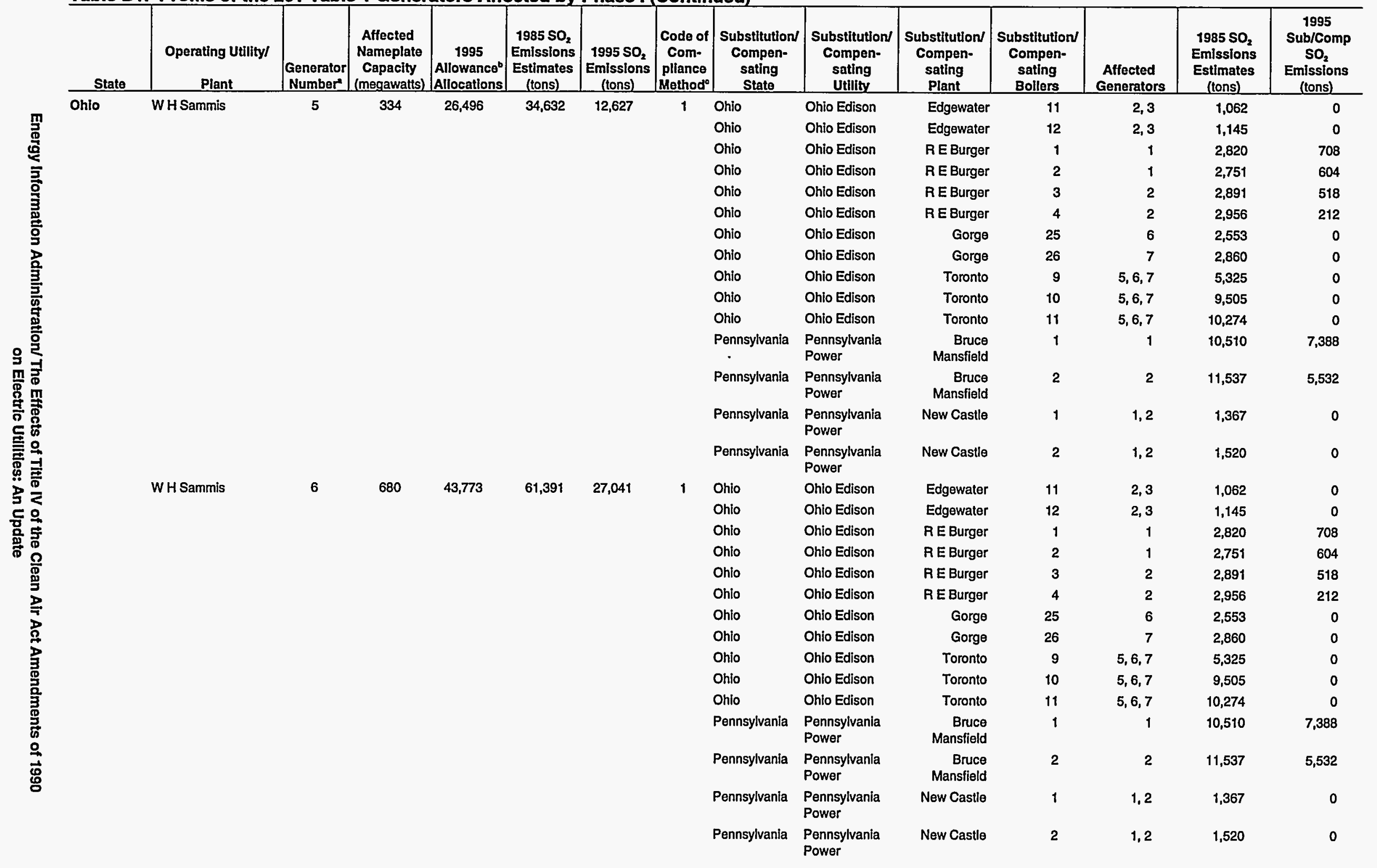


Table B1. Proflle of the 261 Table 1 Generators Affected by Phase I (Continued)

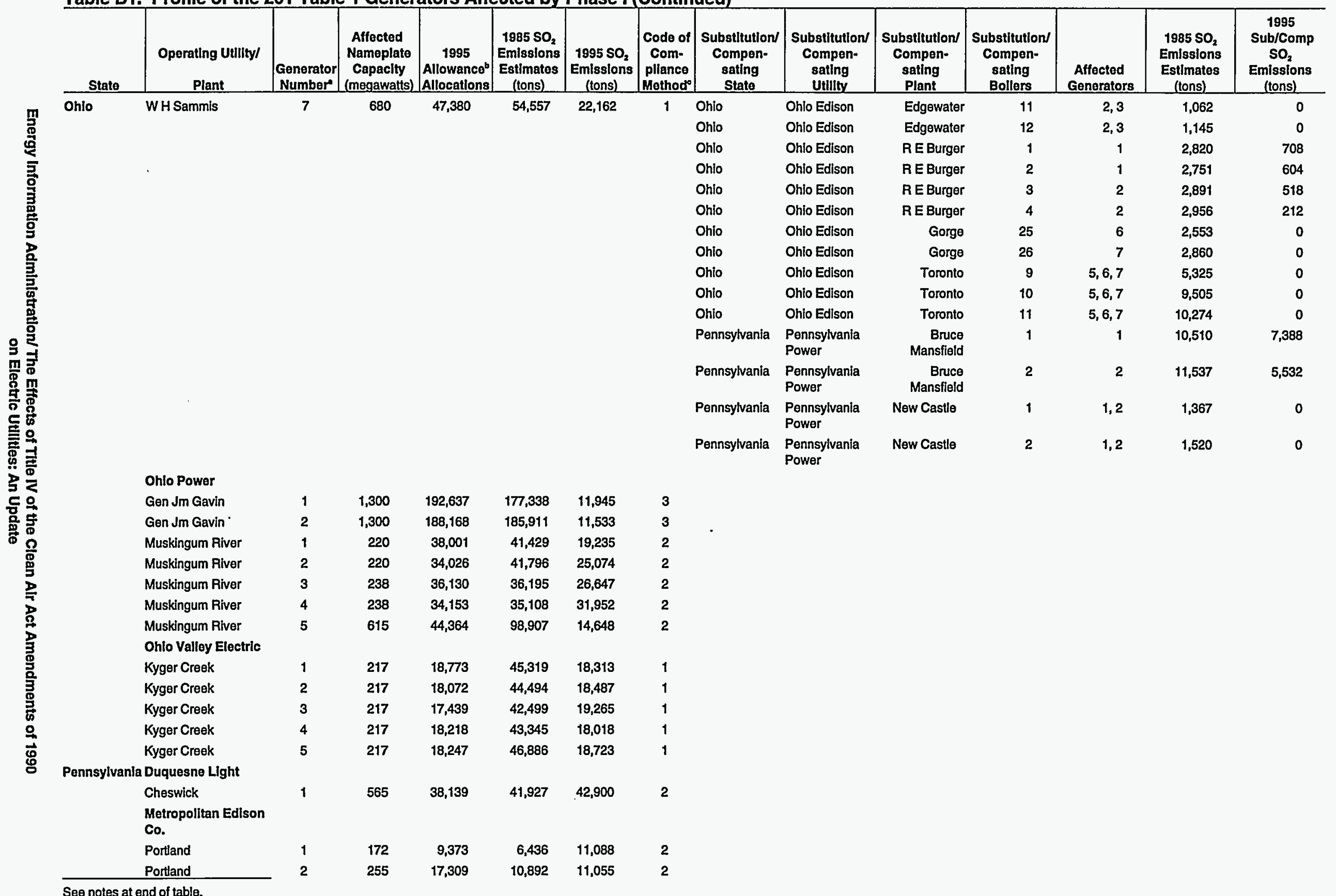


Table B1. Profile of the 261 Table 1 Generators Affected by Phase I (Continued)

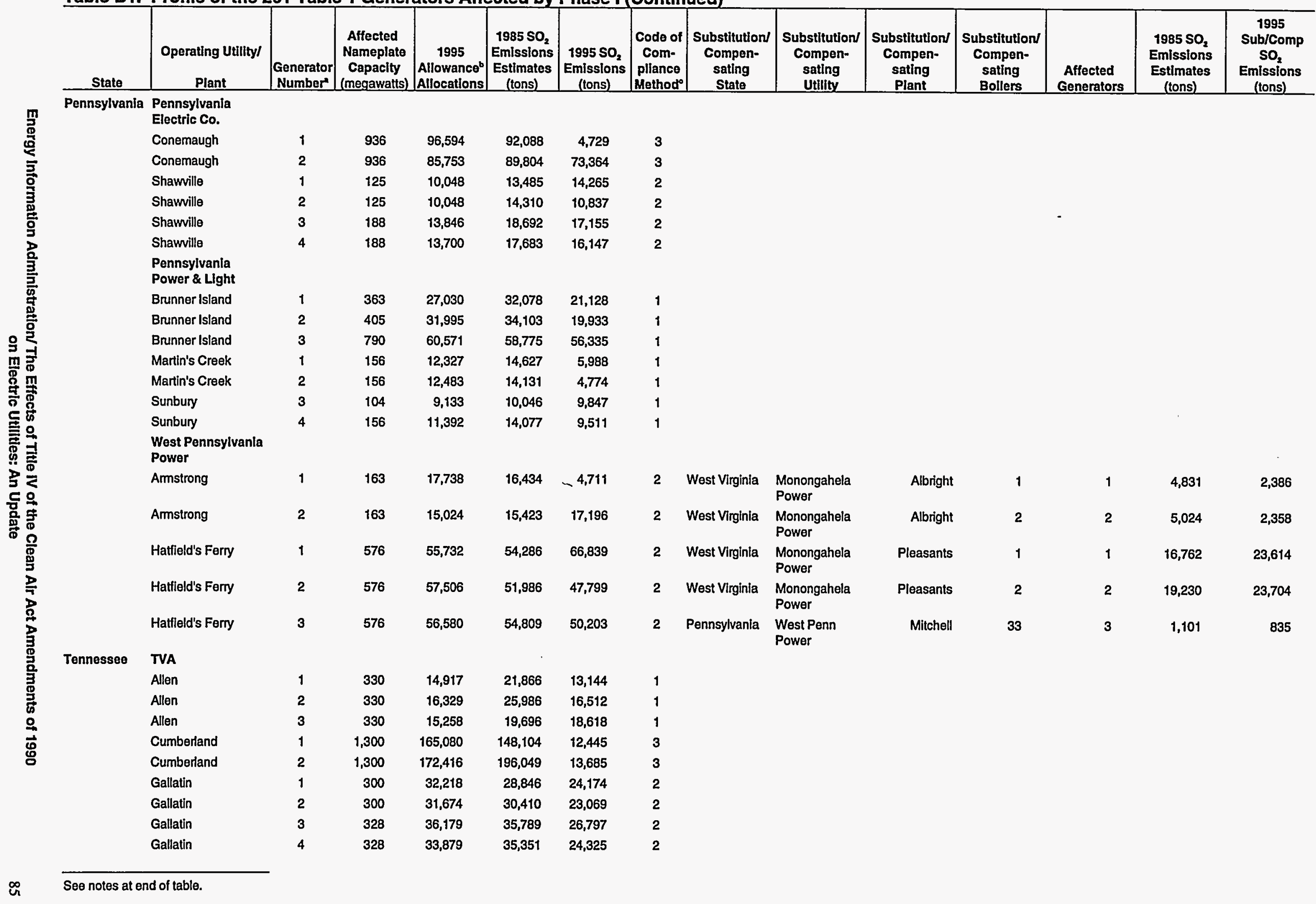


Table B1. Profile of the 261 Table 1 Generators Affected by Phase I (Continued)

\begin{tabular}{|c|c|c|c|c|c|c|c|c|c|c|c|c|c|c|}
\hline \multirow{11}{*}{ 韲 $\frac{\text { State }}{\text { Tennessee }}$} & $\begin{array}{c}\text { Operating Utilityl } \\
\text { Plant } \\
\end{array}$ & \begin{tabular}{|c|} 
Generator \\
Number
\end{tabular} & $\begin{array}{c}\text { Affected } \\
\text { Nameplato } \\
\text { Capacity } \\
\text { (megawatts) }\end{array}$ & $\begin{array}{c}1995 \\
\text { Allowance } \\
\text { Allocatlons }\end{array}$ & $\begin{array}{c}1985 \mathrm{SO}_{2} \\
\text { Emissions } \\
\text { Estimates } \\
\text { (tons) }\end{array}$ & $\begin{array}{c}1995 \mathrm{SO}_{2} \\
\text { Emissions } \\
\text { (tons) }\end{array}$ & $\begin{array}{c}\text { Code of } \\
\text { Com- } \\
\text { pllance } \\
\text { Method }\end{array}$ & $\begin{array}{c}\text { Substitution/ } \\
\text { Compen- } \\
\text { sating } \\
\text { State } \\
\end{array}$ & $\begin{array}{c}\begin{array}{c}\text { Substitution/ } \\
\text { Compen- } \\
\text { sating } \\
\text { Utility }\end{array} \\
\end{array}$ & $\begin{array}{c}\text { Substitution/ } \\
\text { Compen- } \\
\text { sating } \\
\text { Plant } \\
\end{array}$ & $\begin{array}{c}\text { Substitution/ } \\
\text { Compen- } \\
\text { sating } \\
\text { Boilers } \\
\end{array}$ & $\begin{array}{l}\text { Affected } \\
\text { Generators }\end{array}$ & $\begin{array}{c}1985 \mathrm{SO}_{2} \\
\text { Emissions } \\
\text { Estimates } \\
\text { (tons) } \\
\end{array}$ & $\begin{array}{c}1995 \\
\text { Sub/Comp } \\
\text { SO }_{2} \\
\text { Emissions } \\
\text { (tons) } \\
\end{array}$ \\
\hline & Johnsonville & 1 & 125 & 7,585 & 11,123 & 9,722 & 2 & & & & & & & \\
\hline & Johnsonville & 2 & 125 & 7,828 & 10,657 & 9,278 & 2 & & & & & & & \\
\hline & Johnsonville & 3 & 125 & 8,189 & 9,712 & 8,543 & 2 & & & & & & & \\
\hline & Johnsonville & 4 & 125 & 7,780 & 8,968 & 9,853 & 2 & & & & & & & \\
\hline & Johnsonville & 5 & 147 & 8,023 & 8,544 & 12,233 & 2 & & & & & & & \\
\hline & Johnsonville & 6 & 147 & 7,682 & 8,767 & 10,583 & 2 & & & & & & & \\
\hline & Johnsonville & 7 & 173 & 8,744 & 10,389 & 15,784 & 2 & & & & & & & \\
\hline & Johnsonville & 8 & 173 & 8,471 & 10,207 & 12,397 & 2 & & & & & & & \\
\hline & Johnsonville & 9 & 173 & 6,894 & 8,922 & 13,292 & 2 & & & & & & & \\
\hline & Johnsonville & 10 & 173 & 7,351 & 8,835 & 12,991 & 2 & & & & & & & \\
\hline \multirow[t]{17}{*}{ 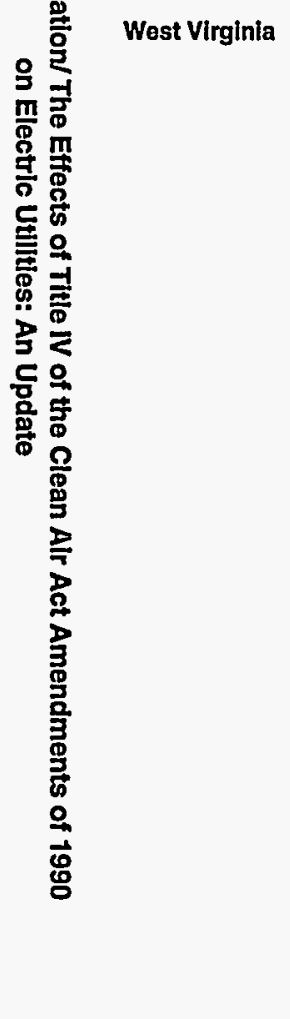 } & $\begin{array}{l}\text { Monongahela } \\
\text { Power }\end{array}$ & & & & & & & & & & & & & \\
\hline & Albright & 3 & 140 & 11,684 & 11,938 & 11,444 & 2 & Maryland & $\begin{array}{l}\text { Potomac } \\
\text { Edison }\end{array}$ & R P Smith & 9 & 3 & 386 & 118 \\
\hline & Fort Martin & 2 & 576 & 44,118 & 44,824 & 43,171 & 2 & Maryland & $\begin{array}{l}\text { Potomac } \\
\text { Edison }\end{array}$ & RP Smith & 11 & 4 & 3,128 & 1,536 \\
\hline & Harrison & 1 & 684 & 82,613 & 78,231 & 3,323 & 3 & West Virginia & $\begin{array}{l}\text { Monongahela } \\
\text { Power }\end{array}$ & Rivesville & 7 & 5 & 1,009 & 488 \\
\hline & & & & & & & & West Virginia & $\begin{array}{l}\text { Monongahela } \\
\text { Power }\end{array}$ & Rivesville & 8 & 6 & 3,059 & 1,357 \\
\hline & Harrison & 2 & 684 & 91,180 & 78,231 & 3,373 & 3 & & & & & & & \\
\hline & Harrison & 3 & 684 & 90,727 & 78,231 & 3,249 & 3 & West Virginia & $\begin{array}{l}\text { Monongahela } \\
\text { Power }\end{array}$ & Willow Island & 1 & 1 & 1,855 & 2,099 \\
\hline & . & & & & & & & West Virginia & $\begin{array}{l}\text { Monongahela } \\
\text { Power }\end{array}$ & Willow Island & 2 & 2 & 7,765 & 7,908 \\
\hline & Ohlo Power & & & & & & & & & & & & & \\
\hline & Kammer & 1 & 238 & 18,247 & 48,863 & 36,224 & 2 & & & & & & & \\
\hline & Kammer & 2 & 238 & 18,948 & 57,963 & 42,224 & 2 & & & & & & & \\
\hline & Kammer & 3 & 238 & 16,932 & 50,208 & 43,745 & 2 & & & & & & & \\
\hline & Mitchell & 1 & 816 & 42,823 & 48,079 & 26,492 & 1 & & & & & & & \\
\hline & Mitchell & 2 & 816 & 44,312 & 55,247 & 35,131 & 1 & & & & & & & \\
\hline & $\begin{array}{l}\text { Virginla Electric \& } \\
\text { Power }\end{array}$ & & & & & & & & & & & & & \\
\hline & Mt. Storm & 2 & 570 & 45,203 & 35,817 & 49,688 & 2 & & & & & & & \\
\hline & Mt. Storm & 3 & 522 & 49,859 & 43,906 & 2,549 & 3 & & & & & & & \\
\hline
\end{tabular}


Table B1. Profile of the 261 Table 1 Generators Affected by Phase I (Continued)

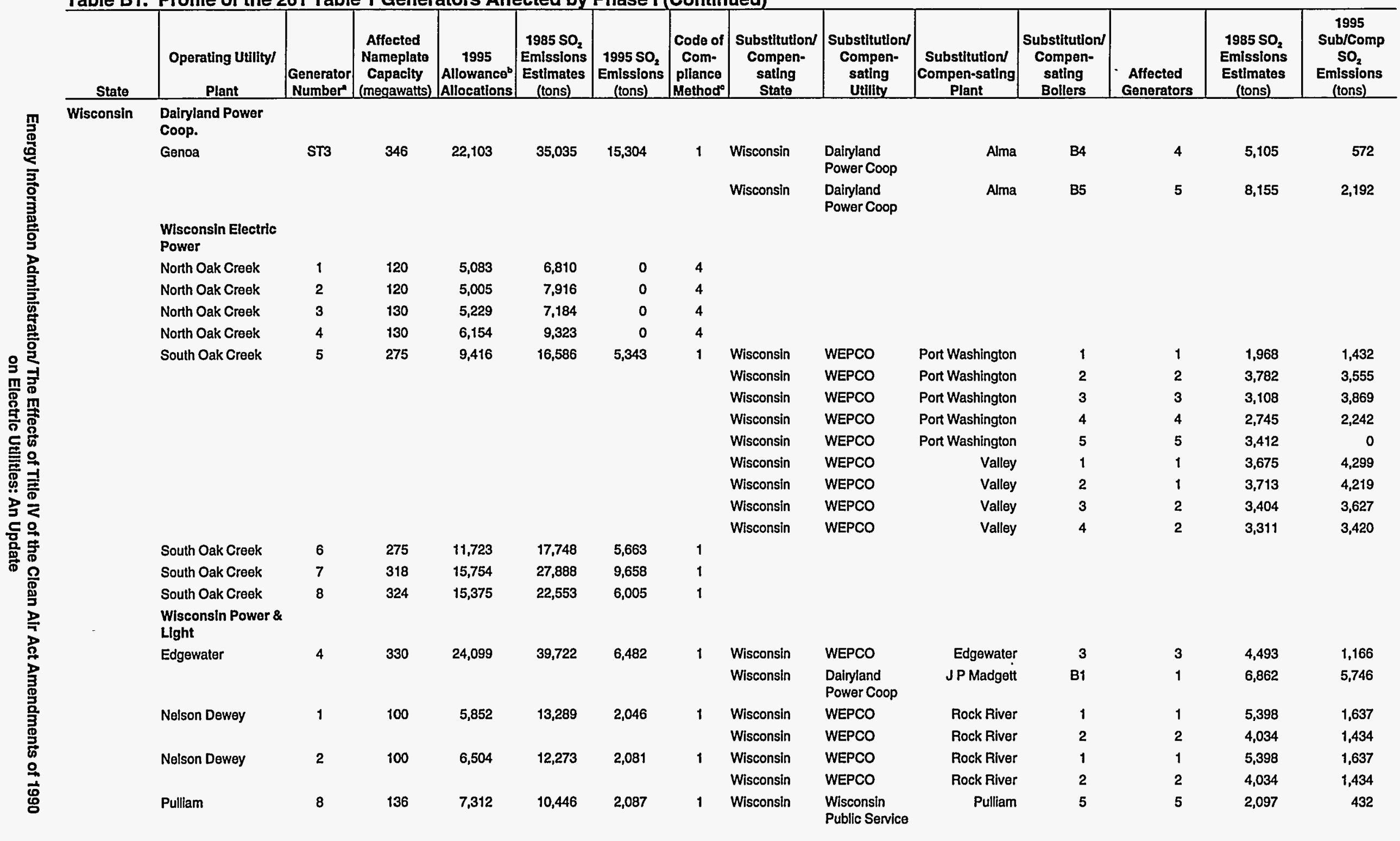


Table B1. Proflle of the 261 Table 1 Generators Affected by Phase I (Continued)

\begin{tabular}{|c|c|c|c|c|c|c|c|c|c|c|c|c|c|c|}
\hline State & $\begin{array}{c}\text { Operating Utilltyl } \\
\text { Plant } \\
\end{array}$ & $\begin{array}{l}\text { Generator } \\
\text { Number }\end{array}$ & $\begin{array}{l}\text { Affocted } \\
\text { Nameplato } \\
\text { Capacity } \\
\text { (megawatts) }\end{array}$ & $\begin{array}{c}1995 \\
\text { Allowance' } \\
\text { Allocations }\end{array}$ & $\begin{array}{c}1985 \mathrm{SO}_{2} \\
\text { Emlssions } \\
\text { Estimates } \\
\text { (tons) } \\
\end{array}$ & $\begin{array}{c}1995 \mathrm{SO}_{2} \\
\text { Emisslons } \\
\text { (tons) }\end{array}$ & $\begin{array}{c}\text { Code of } \\
\text { Com- } \\
\text { pllance } \\
\text { Method }\end{array}$ & $\begin{array}{c}\text { Substitution/ } \\
\text { Compen- } \\
\text { sating } \\
\text { State }\end{array}$ & $\begin{array}{c}\text { Substitutlon/ } \\
\text { Compen- } \\
\text { sating } \\
\text { Utility }\end{array}$ & $\begin{array}{c}\text { Substitution/ } \\
\text { Compen- } \\
\text { sating } \\
\text { Plant }\end{array}$ & $\begin{array}{c}\text { Substitutlon/ } \\
\text { Compen- } \\
\text { sating } \\
\text { Bollers } \\
\end{array}$ & $\begin{array}{c}\text { Affected } \\
\text { Generators }\end{array}$ & $\begin{array}{c}1985 \mathrm{SO}_{2} \\
\text { Emisslons } \\
\text { Estimates } \\
\text { (tons) }\end{array}$ & $\begin{array}{c}1995 \\
\text { Sub/Comp } \\
\mathrm{SO}_{2} \\
\text { Emissions } \\
\text { (tons) }\end{array}$ \\
\hline \multirow[t]{5}{*}{ Misconsin } & & & & & & & & Wisconsin & $\begin{array}{l}\text { Wisconsin } \\
\text { Public Service }\end{array}$ & Pulliam & 6 & 6 & 2,844 & 720 \\
\hline & & & & & & & & Wisconsin & $\begin{array}{l}\text { Wisconsin } \\
\text { Public Service }\end{array}$ & Pulliam & 7 & 7 & 7,317 & 1,466 \\
\hline & & & & & & & & Wisconsin & $\begin{array}{l}\text { Wisconsin } \\
\text { Public Service }\end{array}$ & Weston & 1 & 1 & 1,579 & 969 \\
\hline & & & & & & & & Wisconsin & $\begin{array}{l}\text { Wisconsin } \\
\text { Public Service }\end{array}$ & Weston & 2 & 2 & 3,580 & 1,936 \\
\hline & & & & & & & & Wisconsin & $\begin{array}{l}\text { Wisconsin } \\
\text { Public Service }\end{array}$ & Weston & 3 & 3 & 6,555 & 7,478 \\
\hline
\end{tabular}

"Cincinnati Gas \& Electric's Miami Fort generator 5 has two boilers as does Ohlo Edison's R.E. Burger generator 3. Therefore, the total number of Table 1 boilers is 263 and the number of Table 1 generators is 261. One $\mathrm{SO}_{2}$ allowance permits one ton of $\mathrm{SO}_{2}$ emissions.

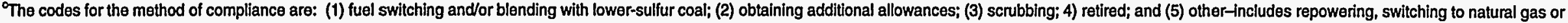
petroleum.

'Miami Fort generator 5 has two boilers. Allowances, $1985 \mathrm{SO}_{2}$ emissions estimates, and 1995 emissions for the boilers were added to provide generator-level data

R.E. Burger generator 3 has two bollers. Allowances and $1985 \mathrm{SO}_{2}$ emissions estimates and 1995 emissions for the boilers were added to provide generator-level data.

$\mathrm{SO}_{2}=$ Sultur dioxide

TVA = Tennessee Valley Authority.

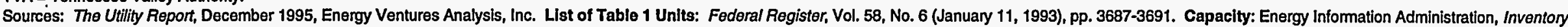

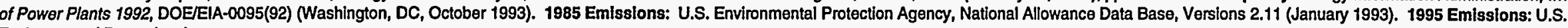

Environmental Protection Agency. 
Table B2. Profile of Coal Received at Table 1 Plants, 1995

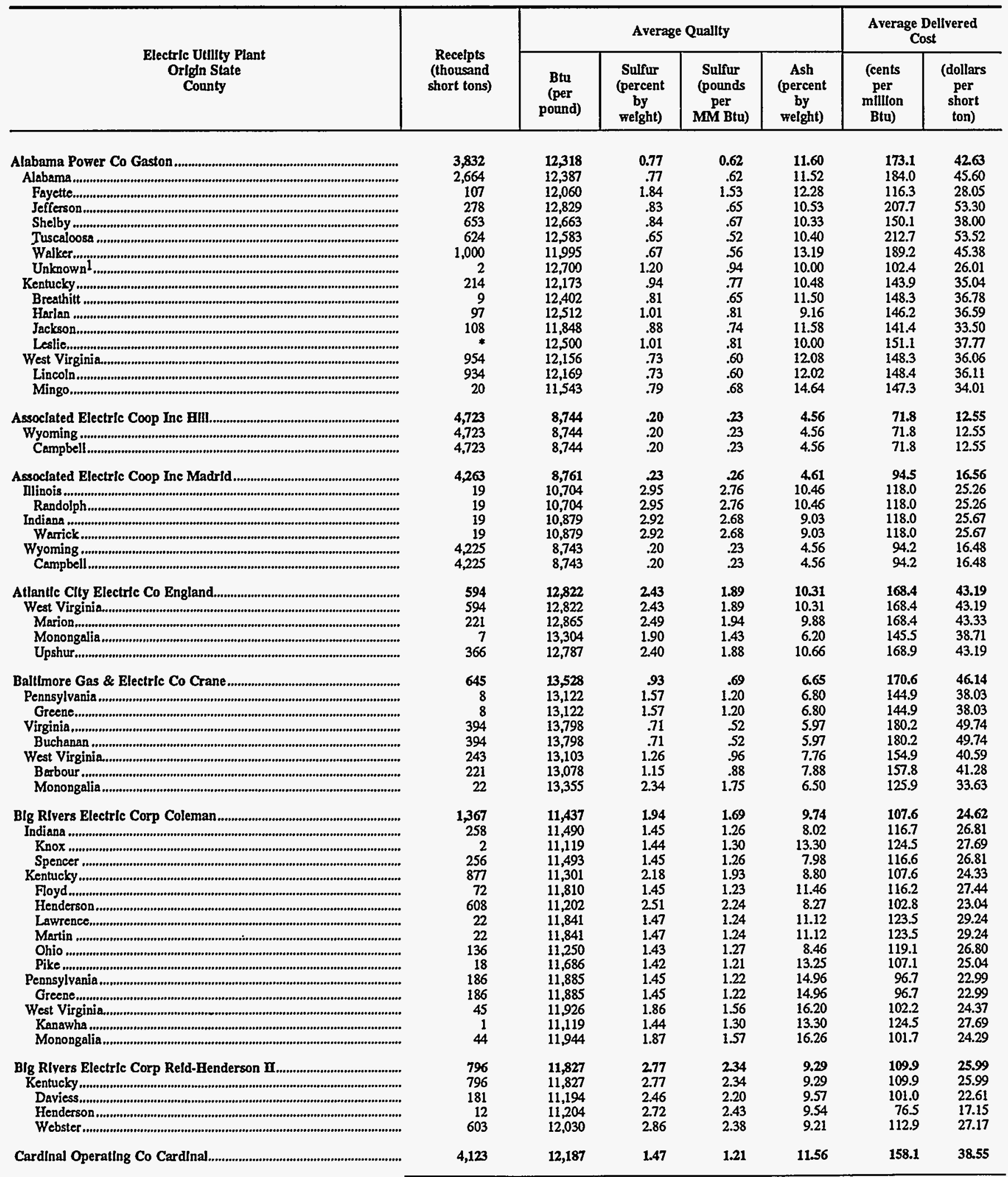

See footnotes at end of table. 
Table B2. Profile of Coal Received at Table 1 Plants, 1995 (Continued)

\begin{tabular}{|c|c|c|c|c|c|c|c|}
\hline \multirow[b]{2}{*}{$\begin{array}{c}\text { Electric Utllity Pant } \\
\text { Orlgin State } \\
\text { County }\end{array}$} & \multirow[b]{2}{*}{$\begin{array}{l}\text { Recelpts } \\
\text { (thousand } \\
\text { short tons) }\end{array}$} & \multicolumn{4}{|c|}{ Average Quality } & \multicolumn{2}{|c|}{$\begin{array}{l}\text { Average Dellvered } \\
\text { Cost }\end{array}$} \\
\hline & & $\begin{array}{c}\text { Btu } \\
\text { (per } \\
\text { pound) }\end{array}$ & $\begin{array}{l}\text { Sulfur } \\
\text { (percent } \\
\text { by } \\
\text { welght) }\end{array}$ & $\begin{array}{c}\text { Sulfur } \\
\text { (pounds } \\
\text { per } \\
\text { MM Btu) }\end{array}$ & $\begin{array}{c}\text { Ash } \\
\text { (percent } \\
\text { by } \\
\text { welght) }\end{array}$ & $\begin{array}{l}\text { (cents } \\
\text { per } \\
\text { million } \\
\text { Btu) }\end{array}$ & $\begin{array}{l}\text { (dollars } \\
\text { per } \\
\text { short } \\
\text { ton) }\end{array}$ \\
\hline \multicolumn{8}{|l|}{ Cardinal Operating Co Cardinal } \\
\hline 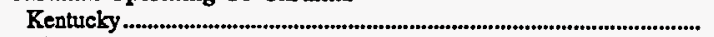 & 611 & 12,111 & 0.67 & 0.55 & 10.56 & 138.3 & 33.49 \\
\hline 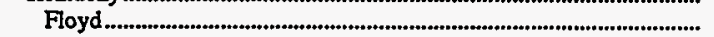 & 43 & 12,139 & .71 & .59 & 12.28 & 138.0 & 33.51 \\
\hline 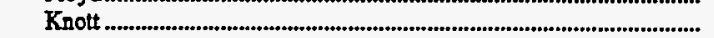 & 175 & 12,099 & .65 & .54 & 9.89 & 138.4 & 33.49 \\
\hline Magofin & 219 & 12,099 & .65 & .54 & 9.89 & 138.4 & 33.49 \\
\hline Perу & 44 & 12,099 & .65 & .54 & 9.89 & 138.4 & 33.49 \\
\hline Pike & 130 & 12,140 & .71 & .59 & 12.25 & 138.0 & 33.51 \\
\hline 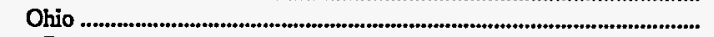 & 254 & 11,906 & 2.87 & 2.41 & 12.30 & 103.9 & 24.73 \\
\hline 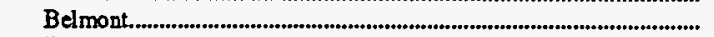 & 211 & 11,836 & 2.83 & 2.39 & 12.37 & 110.3 & 26.12 \\
\hline 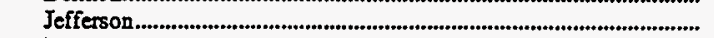 & 43 & 12,254 & 3.09 & 2.52 & 11.94 & 72.9 & 17.86 \\
\hline 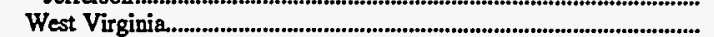 & 3,258 & 12,223 & 1.51 & 1.24 & 11.69 & 166.0 & 40.57 \\
\hline 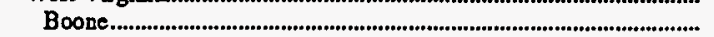 & 89 & 12,146 & .68 & .56 & 12.24 & 136.9 & 33.25 \\
\hline 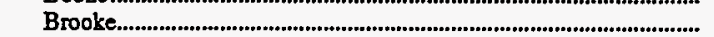 & 1,040 & 12,306 & 3.27 & 2.66 & 9.96 & 194.4 & 47.84 \\
\hline 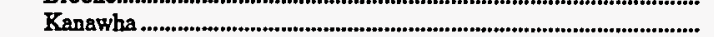 & 331 & 12,344 & .70 & .57 & 12.07 & 164.7 & 40.67 \\
\hline 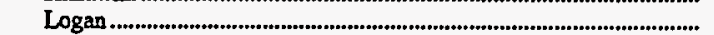 & 1,477 & 12,125 & .65 & .53 & 12.67 & 156.3 & 37.91 \\
\hline 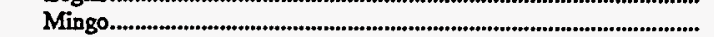 & 89 & 12,151 & .68 & .56 & 12.11 & 137.2 & 33.34 \\
\hline 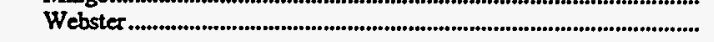 & 232 & 12,356 & .92 & .74 & 12.26 & 122.8 & 30.34 \\
\hline 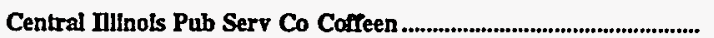 & 1,690 & 10,266 & .91 & .88 & 8.16 & 171.8 & 35.28 \\
\hline 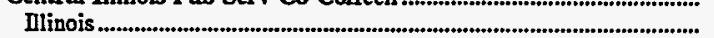 & 1,690 & 10,266 & .91 & .88 & 8.16 & 171.8 & 35.28 \\
\hline Macoupin & 1,690 & 10,266 & .91 & .88 & 8.16 & 171.8 & 35.28 \\
\hline Central Illinols Pab Serv Co Grand Tower........................................... & 150 & 11,401 & 285 & 2.50 & 11.40 & 190.8 & $\mathbf{4 3 . 5 0}$ \\
\hline Illinois & 150 & 11,401 & 2.85 & 2.50 & 11.40 & 190.8 & 43.50 \\
\hline 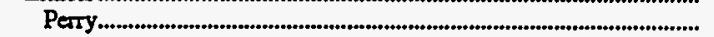 & 28 & 10,923 & 3.05 & 2.79 & 10.20 & 192.3 & 42.01 \\
\hline 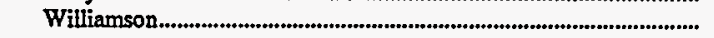 & 122 & 11,509 & 2.81 & 2.44 & 11.67 & 190.5 & 43.84 \\
\hline 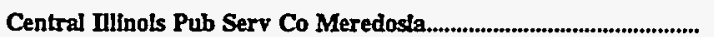 & 509 & 11,067 & 2.19 & 1.98 & 5.69 & 152.6 & 33.79 \\
\hline 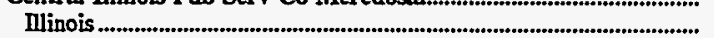 & 509 & 11,067 & 2.19 & 1.98 & 5.69 & 152.6 & 33.79 \\
\hline Macoupin & 116 & 10,311 & .89 & .86 & 8.15 & 138.3 & 28.52 \\
\hline 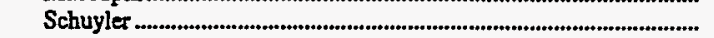 & 393 & 11,290 & 2.57 & 2.28 & 4.97 & 156.5 & 35.34 \\
\hline 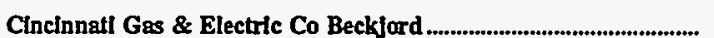 & 2,192 & 11,915 & .98 & .82 & 1288 & 160.5 & 38.25 \\
\hline 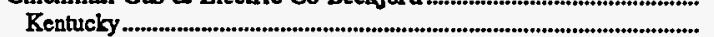 & 1,781 & 11,820 & .88 & .74 & 13.45 & 171.1 & 40.44 \\
\hline Breathitt & 100 & 12,016 & .91 & .76 & 10.52 & 119.5 & 28.72 \\
\hline 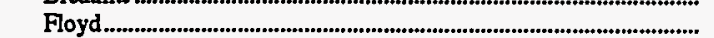 & 52 & 11,858 & .86 & .73 & 12.09 & 109.3 & 25.93 \\
\hline Johnson & 10 & 11,513 & .93 & .80 & 13.04 & 102.5 & 23.61 \\
\hline 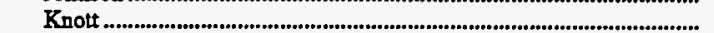 & 8 & 11,650 & .91 & .78 & 12.61 & 113.6 & 26.48 \\
\hline Knox & 8 & 11,979 & 1.17 & .98 & 12.50 & 101.8 & 24.39 \\
\hline 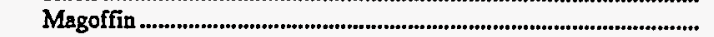 & 167 & 11,744 & 1.14 & .97 & 12.43 & 154.5 & 36.28 \\
\hline 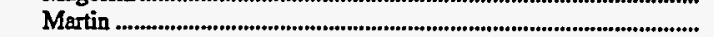 & 1,189 & 11,763 & .84 & .72 & 14.60 & 192.8 & 45.36 \\
\hline 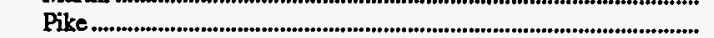 & 245 & 12,074 & .85 & .70 & 10.10 & 120.1 & 29.00 \\
\hline 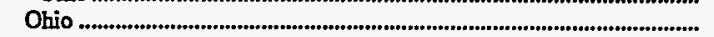 & 55 & 12,478 & 4.01 & 3.21 & 9.48 & 94.0 & 23.46 \\
\hline 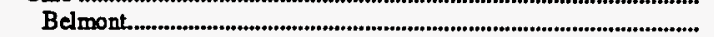 & 49 & 12,521 & 3.98 & 3.18 & 9.34 & 94.3 & 23.62 \\
\hline Harrison & 6 & 12,115 & 4.25 & 3.51 & 10.68 & 91.2 & 22.11 \\
\hline 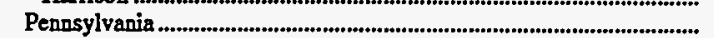 & 35 & 13,186 & 1.62 & 1.23 & 7.39 & 104.9 & 27.66 \\
\hline 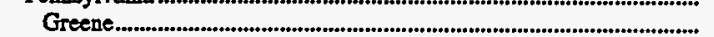 & 35 & 13,186 & 1.62 & 1.23 & 7.39 & 104.9 & 27.66 \\
\hline 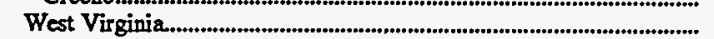 & 320 & 12,206 & .97 & .79 & 10.93 & 121.9 & 29.76 \\
\hline Boone. & 11 & 12,245 & .71 & .58 & 13.32 & 114.1 & 27.94 \\
\hline 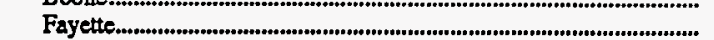 & 5 & 12,157 & 2.20 & 1.81 & 13.70 & 83.7 & 20.35 \\
\hline 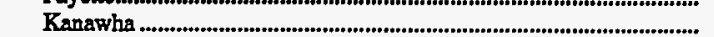 & 169 & 12,129 & .83 & $\begin{array}{r}2.02 \\
.68\end{array}$ & 11.48 & 124.4 & 30.17 \\
\hline Logan & 3 & 11,310 & 1.12 & .00 & 14.10 & 101.0 & 22.85 \\
\hline 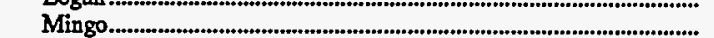 & 108 & 12,102 & $\begin{array}{r}1.12 \\
.86\end{array}$ & .71 & 10.56 & 125.0 & 30.27 \\
\hline 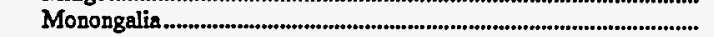 & 24 & 13,348 & 2.36 & 1.77 & 6.49 & 105.7 & 28.21 \\
\hline Clncinnatl Gas \& Electric Co Mlaml Fort........................................... & 2,663 & 12,138 & .82 & .68 & 11.79 & 143.2 & 34.76 \\
\hline 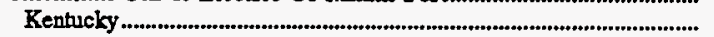 & 1,254 & 11,901 & .82 & .69 & 12.55 & 149.0 & 35.46 \\
\hline Breathitt & 42 & 11,950 & .88 & .73 & 10.30 & 117.9 & 28.18 \\
\hline Floyd & 567 & 11,980 & .69 & .57 & 12.09 & 127.8 & 30.63 \\
\hline Johnson & 8 & 11,316 & .93 & .82 & 14.58 & 99.4 & 22.50 \\
\hline Knott & 48 & 11,867 & .68 & .57 & 11.13 & 123.0 & 29.20 \\
\hline 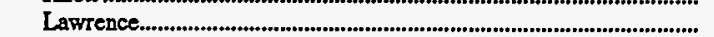 & 8 & 11,742 & 1.77 & 1.51 & 11.32 & 91.1 & 21.40 \\
\hline 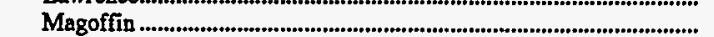 & 174 & 11,657 & 1.29 & 1.11 & 13.92 & 189.7 & 44.22 \\
\hline Martin & 296 & 11,865 & $\begin{array}{r}1.29 \\
.83\end{array}$ & $\begin{array}{r}1.11 \\
.70\end{array}$ & 13.59 & 187.0 & 44.38 \\
\hline Pike & 110 & 12,027 & .72 & .60 & 11.34 & 125.2 & 30.12 \\
\hline
\end{tabular}

See footnotes at end of table. 
Table B2. Profile of Coal Received at Table 1 Plants, 1995 (Continued)

\begin{tabular}{|c|c|c|c|c|c|c|c|}
\hline \multirow{2}{*}{$\begin{array}{l}\text { Electric Utjlity Plant } \\
\text { OrIgin State } \\
\text { County }\end{array}$} & \multirow[b]{2}{*}{$\begin{array}{l}\text { Recelpts } \\
\text { (thousand } \\
\text { short tons) }\end{array}$} & \multicolumn{4}{|c|}{ Average Quallty } & \multicolumn{2}{|c|}{$\begin{array}{l}\text { Average Dellvered } \\
\text { Cost }\end{array}$} \\
\hline & & $\begin{array}{l}\text { Btu } \\
\text { (per } \\
\text { pound) }\end{array}$ & $\begin{array}{l}\text { Sulfur } \\
\text { (percent } \\
\text { by } \\
\text { welght) }\end{array}$ & $\begin{array}{l}\text { Sulfur } \\
\text { (pounds } \\
\text { per } \\
\text { MM Btu) }\end{array}$ & $\begin{array}{l}\text { Ash } \\
\text { (percent } \\
\text { by } \\
\text { welght) }\end{array}$ & $\begin{array}{l}\text { (cents } \\
\text { per } \\
\text { million } \\
\text { Btu) }\end{array}$ & $\begin{array}{l}\text { (dollars } \\
\text { per } \\
\text { short } \\
\text { ton) }\end{array}$ \\
\hline 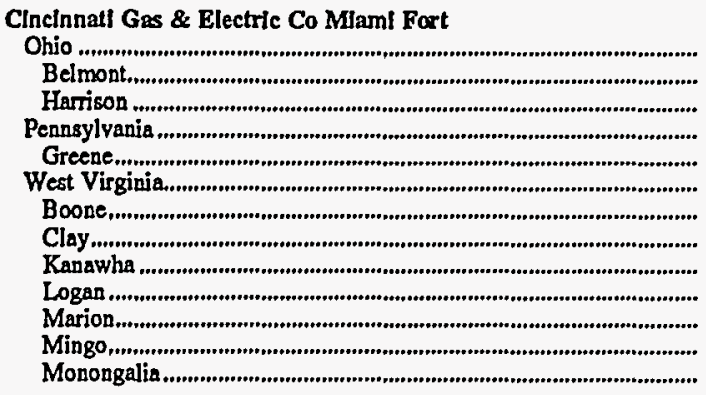 & $\begin{array}{r}31 \\
30 \\
2 \\
11 \\
11 \\
1,367 \\
9 \\
381 \\
805 \\
102 \\
2 \\
42 \\
26\end{array}$ & $\begin{array}{l}12,554 \\
12,579 \\
12,124 \\
13,204 \\
13,204 \\
12,338 \\
12,340 \\
12,206 \\
12,403 \\
12,155 \\
12,742 \\
12,094 \\
13,339\end{array}$ & $\begin{array}{r}4.01 \\
4.00 \\
4.22 \\
2.46 \\
2.46 \\
.74 \\
.72 \\
.68 \\
.71 \\
.69 \\
2.61 \\
.80 \\
2.40\end{array}$ & $\begin{array}{r}3.20 \\
3.18 \\
3.48 \\
1.86 \\
1.86 \\
.60 \\
.58 \\
.55 \\
.57 \\
.57 \\
2.05 \\
.66 \\
1.80\end{array}$ & $\begin{array}{r}9.31 \\
9.24 \\
10.60 \\
8.00 \\
8.00 \\
11.18 \\
12.90 \\
11.88 \\
11.06 \\
10.97 \\
10.00 \\
10.14 \\
6.49\end{array}$ & $\begin{array}{r}92.2 \\
92.0 \\
96.0 \\
103.8 \\
103.8 \\
139.6 \\
118.3 \\
119.8 \\
152.7 \\
126.3 \\
114.8 \\
124.6 \\
106.2\end{array}$ & $\begin{array}{l}23.15 \\
23.14 \\
23.28 \\
27.41 \\
27.41 \\
34.44 \\
29.20 \\
29.25 \\
37.87 \\
30.71 \\
29.26 \\
30.13 \\
28.33\end{array}$ \\
\hline 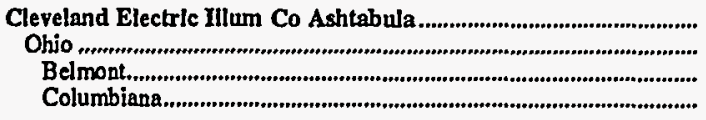 & $\begin{array}{r}621 \\
621 \\
539 \\
82\end{array}$ & $\begin{array}{l}12,635 \\
12,635 \\
12,682 \\
12,324\end{array}$ & $\begin{array}{l}3.86 \\
3.86 \\
4.03 \\
2.75\end{array}$ & $\begin{array}{l}3.06 \\
3.06 \\
3.18 \\
2.23\end{array}$ & $\begin{array}{r}9.31 \\
9.31 \\
9.07 \\
10.91\end{array}$ & $\begin{array}{l}165.3 \\
165.3 \\
171.2 \\
125.3\end{array}$ & $\begin{array}{l}41.76 \\
41.76 \\
43.42 \\
30.88\end{array}$ \\
\hline 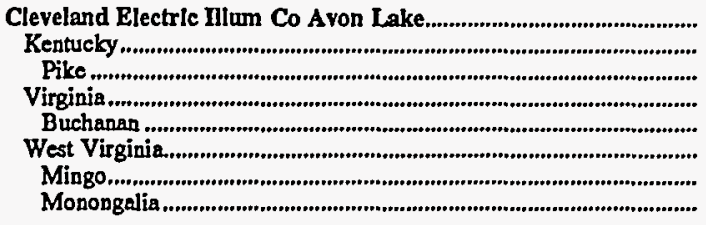 & $\begin{array}{r}1,615 \\
263 \\
263 \\
89 \\
89 \\
1,263 \\
1,123 \\
140\end{array}$ & $\begin{array}{l}12,741 \\
12,416 \\
12,416 \\
12,646 \\
12,646 \\
12,815 \\
12,767 \\
13,196\end{array}$ & $\begin{array}{l}.85 \\
.66 \\
.66 \\
.85 \\
.85 \\
.89 \\
.69 \\
2.48\end{array}$ & $\begin{array}{r}.67 \\
.53 \\
.53 \\
.67 \\
.67 \\
.70 \\
.54 \\
1.88\end{array}$ & $\begin{array}{l}8.88 \\
8.91 \\
8.91 \\
8.51 \\
8.51 \\
8.90 \\
9.07 \\
7.59\end{array}$ & $\begin{array}{l}152.3 \\
155.5 \\
155.5 \\
146.7 \\
146.7 \\
152.1 \\
155.4 \\
126.7\end{array}$ & $\begin{array}{l}38.82 \\
38.62 \\
38.62 \\
37.10 \\
37.10 \\
38.98 \\
39.68 \\
33.43\end{array}$ \\
\hline 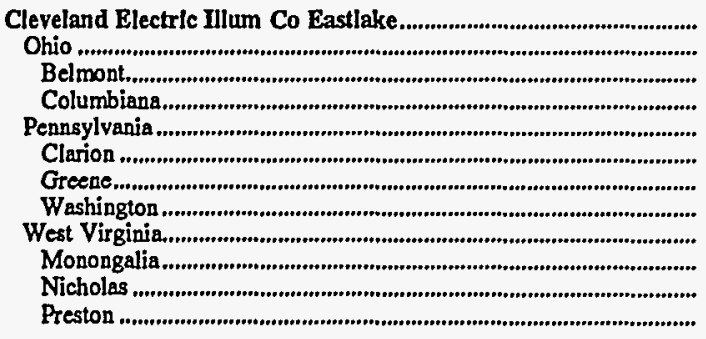 & $\begin{array}{r}2,398 \\
1,008 \\
758 \\
250 \\
1,279 \\
60 \\
876 \\
343 \\
111 \\
93 \\
9 \\
9\end{array}$ & $\begin{array}{l}12,999 \\
12,726 \\
12,762 \\
12,615 \\
13,215 \\
12,949 \\
13,177 \\
13,361 \\
12,987 \\
13,030 \\
12,785 \\
12,739\end{array}$ & $\begin{array}{l}239 \\
3.55 \\
4.10 \\
1.89 \\
1.50 \\
1.45 \\
1.50 \\
1.49 \\
2.13 \\
2.17 \\
1.68 \\
2.16\end{array}$ & $\begin{array}{l}1.84 \\
2.79 \\
3.21 \\
1.50 \\
1.13 \\
1.12 \\
1.14 \\
1.12 \\
1.64 \\
1.67 \\
1.31 \\
1.70\end{array}$ & $\begin{array}{l}7.69 \\
8.83 \\
8.99 \\
8.37 \\
6.87 \\
7.83 \\
6.84 \\
6.77 \\
6.68 \\
6.21 \\
8.70 \\
9.60\end{array}$ & $\begin{array}{l}142.0 \\
162.9 \\
175.5 \\
124.0 \\
127.8 \\
129.5 \\
127.7 \\
127.7 \\
121.8 \\
120.5 \\
133.9 \\
124.0\end{array}$ & $\begin{array}{l}36.90 \\
41.45 \\
44.80 \\
31.28 \\
33.78 \\
33.54 \\
33.66 \\
34.12 \\
31.64 \\
31.40 \\
34.24 \\
31.59\end{array}$ \\
\hline 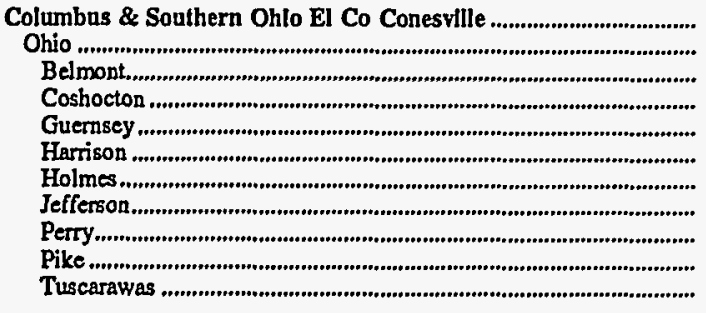 & $\begin{array}{r}3,417 \\
3,417 \\
64 \\
1,625 \\
17 \\
608 \\
27 \\
88 \\
316 \\
102 \\
570\end{array}$ & $\begin{array}{l}11,910 \\
11,910 \\
11,609 \\
11,953 \\
11,519 \\
12,618 \\
11,238 \\
11,963 \\
11,294 \\
11,941 \\
11,438\end{array}$ & $\begin{array}{l}2.88 \\
2.88 \\
3.61 \\
2.52 \\
3.12 \\
3.02 \\
3.63 \\
2.54 \\
3.20 \\
2.60 \\
3.58\end{array}$ & $\begin{array}{l}2.42 \\
2.42 \\
3.11 \\
2.10 \\
2.71 \\
2.39 \\
3.23 \\
2.13 \\
2.83 \\
2.18 \\
3.13\end{array}$ & $\begin{array}{r}8.81 \\
8.81 \\
12.25 \\
7.27 \\
11.83 \\
8.62 \\
10.72 \\
11.46 \\
11.93 \\
6.80 \\
11.07\end{array}$ & $\begin{array}{r}146.5 \\
146.5 \\
93.8 \\
180.9 \\
101.1 \\
115.1 \\
94.9 \\
101.4 \\
112.2 \\
192.8 \\
108.1\end{array}$ & $\begin{array}{l}34.89 \\
34.89 \\
21.78 \\
43.24 \\
23.28 \\
29.04 \\
21.33 \\
24.27 \\
25.35 \\
46.04 \\
24.72\end{array}$ \\
\hline $\begin{array}{l}\text { Columbus \& Southern Ohlo El Co Pictray. } \\
\text { Ohio } \\
\text { Jackson } \\
\text { Vinton }\end{array}$ & $\begin{array}{r}91 \\
91 \\
7 \\
85\end{array}$ & $\begin{array}{l}11,236 \\
11,236 \\
11,147 \\
11,243\end{array}$ & $\begin{array}{l}3.05 \\
3.05 \\
4.07 \\
2.97\end{array}$ & $\begin{array}{l}2.71 \\
2.71 \\
3.65 \\
2.64\end{array}$ & $\begin{array}{l}11.33 \\
11.33 \\
12.80 \\
11.21\end{array}$ & $\begin{array}{r}103.4 \\
103.4 \\
97.1 \\
103.9\end{array}$ & $\begin{array}{l}23.24 \\
23.24 \\
21.65 \\
23.36\end{array}$ \\
\hline 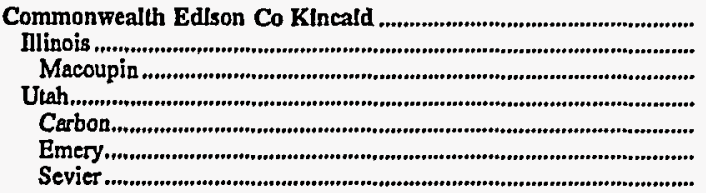 & $\begin{array}{r}1,266 \\
41 \\
41 \\
1,153 \\
795 \\
328 \\
30\end{array}$ & $\begin{array}{l}11,620 \\
10,398 \\
10,398 \\
11,842 \\
11,743 \\
12,105 \\
11,598\end{array}$ & $\begin{array}{l}.45 \\
.85 \\
.85 \\
.45 \\
.44 \\
.46 \\
.34\end{array}$ & $\begin{array}{l}.39 \\
.82 \\
.82 \\
.38 \\
.38 \\
.38 \\
.29\end{array}$ & $\begin{array}{l}7.78 \\
8.20 \\
8.20 \\
7.93 \\
7.77 \\
8.38 \\
7.20\end{array}$ & $\begin{array}{l}145.2 \\
100.8 \\
100.8 \\
138.7 \\
136.9 \\
143.1 \\
137.5\end{array}$ & $\begin{array}{l}33.75 \\
20.95 \\
20.95 \\
32.85 \\
32.15 \\
34.65 \\
31.89\end{array}$ \\
\hline
\end{tabular}

See footnotes at end of table. 
Table B2. Profile of Coal Received at Table 1 Plants, 1995 (Continued)

\begin{tabular}{|c|c|c|c|c|c|c|c|}
\hline \multirow[b]{2}{*}{$\begin{array}{l}\text { Electric Utulty Plant } \\
\text { Origin State } \\
\text { County }\end{array}$} & \multirow[b]{2}{*}{$\begin{array}{l}\text { Recelpts } \\
\text { (thousand } \\
\text { short tons) }\end{array}$} & \multicolumn{4}{|c|}{ Average Quallty } & \multicolumn{2}{|c|}{$\begin{array}{l}\text { Average Dellvered } \\
\text { Cost }\end{array}$} \\
\hline & & $\begin{array}{l}\text { Btu } \\
\text { (per } \\
\text { pound) }\end{array}$ & $\begin{array}{l}\text { Sulfur } \\
\text { (percent } \\
\text { by } \\
\text { melght) }\end{array}$ & $\begin{array}{l}\text { Sulfur } \\
\text { (pounds } \\
\text { per } \\
\text { MM Btu) }\end{array}$ & $\begin{array}{l}\text { Ash } \\
\text { (percent } \\
\text { by } \\
\text { welght) }\end{array}$ & $\begin{array}{l}\text { (cents } \\
\text { per } \\
\text { million } \\
\text { Btu) }\end{array}$ & $\begin{array}{l}\text { (dollars } \\
\text { per } \\
\text { short } \\
\text { ton) }\end{array}$ \\
\hline 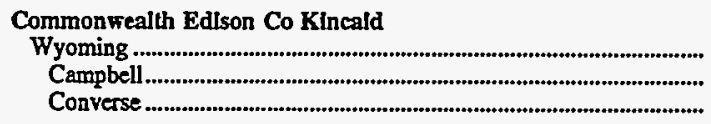 & $\begin{array}{l}72 \\
24 \\
48\end{array}$ & $\begin{array}{l}8,766 \\
8,776 \\
8,761\end{array}$ & $\begin{array}{r}0.29 \\
.21 \\
.32\end{array}$ & $\begin{array}{r}0.33 \\
.24 \\
.37\end{array}$ & $\begin{array}{l}5.07 \\
4.50 \\
5.35\end{array}$ & $\begin{array}{l}315.5 \\
295.3 \\
325.6\end{array}$ & $\begin{array}{l}55.31 \\
51.83 \\
57.05\end{array}$ \\
\hline 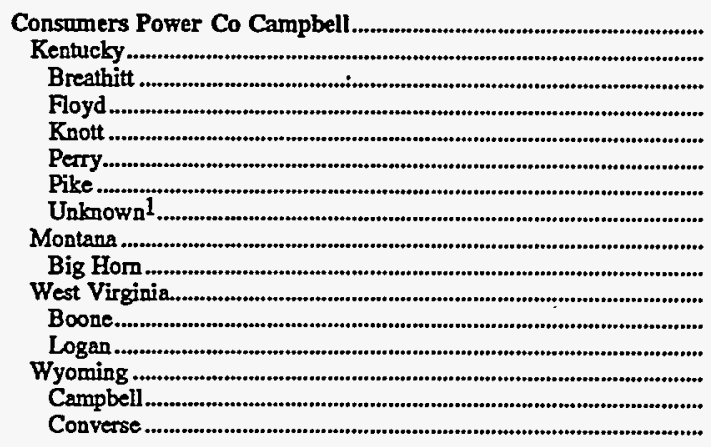 & $\begin{array}{r}3,030 \\
1,201 \\
105 \\
305 \\
114 \\
10 \\
655 \\
13 \\
12 \\
12 \\
1,170 \\
988 \\
182 \\
648 \\
616 \\
31\end{array}$ & $\begin{array}{r}11,631 \\
12,586 \\
12,356 \\
12,455 \\
12,304 \\
12,178 \\
12,732 \\
12,900 \\
9,352 \\
9,352 \\
12,263 \\
12,220 \\
12,499 \\
8,759 \\
8,756 \\
8,815\end{array}$ & $\begin{array}{l}.65 \\
.76 \\
.71 \\
.87 \\
.78 \\
.89 \\
.71 \\
.90 \\
.36 \\
.36 \\
.72 \\
.73 \\
.63 \\
.33 \\
.34 \\
.21\end{array}$ & $\begin{array}{l}.56 \\
.60 \\
.57 \\
.70 \\
.64 \\
.73 \\
.56 \\
.70 \\
.38 \\
.38 \\
.59 \\
.60 \\
.51 \\
.38 \\
.39 \\
.24\end{array}$ & $\begin{array}{r}9.54 \\
9.54 \\
9.65 \\
10.56 \\
10.93 \\
10.77 \\
8.83 \\
7.50 \\
4.10 \\
4.10 \\
11.93 \\
12.02 \\
11.46 \\
5.30 \\
5.30 \\
5.23\end{array}$ & $\begin{array}{l}158.2 \\
161.8 \\
165.4 \\
160.5 \\
158.5 \\
178.7 \\
162.3 \\
157.3 \\
122.0 \\
122.0 \\
169.8 \\
170.7 \\
164.9 \\
120.1 \\
119.9 \\
124.4\end{array}$ & $\begin{array}{l}36.81 \\
40.73 \\
40.87 \\
39.97 \\
39.00 \\
43.53 \\
41.33 \\
40.58 \\
22.82 \\
22.82 \\
41.64 \\
41.72 \\
41.22 \\
21.04 \\
21.00 \\
21.94\end{array}$ \\
\hline 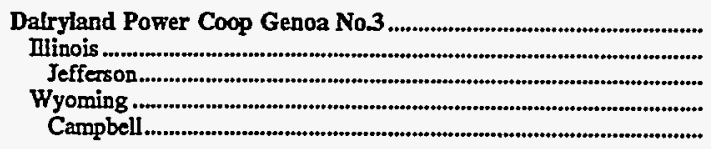 & $\begin{array}{l}953 \\
592 \\
592 \\
361 \\
361\end{array}$ & $\begin{array}{r}10,723 \\
12,093 \\
12,093 \\
8,475 \\
8,475\end{array}$ & $\begin{array}{l}.75 \\
.99 \\
.99 \\
.36 \\
.36\end{array}$ & $\begin{array}{l}.70 \\
.82 \\
.82 \\
.42 \\
.42\end{array}$ & $\begin{array}{l}5.15 \\
5.23 \\
5.23 \\
5.02 \\
5.02\end{array}$ & $\begin{array}{l}127.5 \\
131.1 \\
131.1 \\
119.1 \\
119.1\end{array}$ & $\begin{array}{l}27.35 \\
31.72 \\
31.72 \\
20.19 \\
20.19\end{array}$ \\
\hline 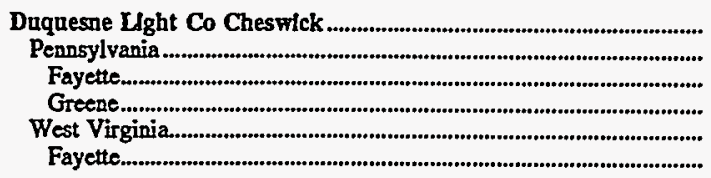 & $\begin{array}{r}1,237 \\
981 \\
302 \\
679 \\
256 \\
256\end{array}$ & $\begin{array}{l}13,016 \\
13,060 \\
12,790 \\
13,181 \\
12,848 \\
12,848\end{array}$ & $\begin{array}{r}1.72 \\
1.92 \\
1.19 \\
2.25 \\
.98 \\
.98\end{array}$ & $\begin{array}{r}1.33 \\
1.47 \\
.93 \\
1.70 \\
.76 \\
.76\end{array}$ & $\begin{array}{l}8.69 \\
8.55 \\
9.36 \\
8.18 \\
9.23 \\
9.23\end{array}$ & $\begin{array}{l}115.9 \\
112.8 \\
133.1 \\
104.0 \\
128.1 \\
128.1\end{array}$ & $\begin{array}{l}30.17 \\
29.46 \\
34.05 \\
27.42 \\
32.92 \\
32.92\end{array}$ \\
\hline 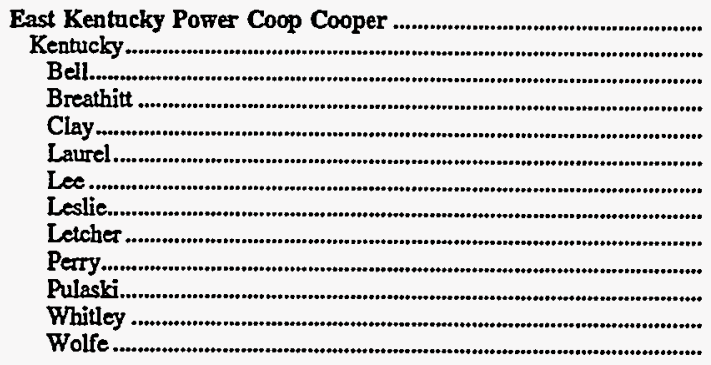 & $\begin{array}{r}609 \\
609 \\
50 \\
4 \\
147 \\
1 \\
6 \\
22 \\
2 \\
33 \\
318 \\
18 \\
8\end{array}$ & $\begin{array}{l}12,398 \\
12,398 \\
12,690 \\
12,166 \\
12,769 \\
11,145 \\
11,974 \\
12,456 \\
12,344 \\
12,473 \\
12,194 \\
12,440 \\
11,908\end{array}$ & $\begin{array}{r}1.28 \\
1.28 \\
.98 \\
1.26 \\
1.15 \\
1.63 \\
1.15 \\
1.13 \\
1.21 \\
.91 \\
1.41 \\
1.71 \\
1.52\end{array}$ & $\begin{array}{r}1.03 \\
1.03 \\
.77 \\
1.04 \\
.90 \\
1.46 \\
.96 \\
.91 \\
.98 \\
.73 \\
1.16 \\
1.38 \\
1.28\end{array}$ & $\begin{array}{r}9.74 \\
9.74 \\
8.17 \\
10.75 \\
7.19 \\
12.70 \\
9.05 \\
9.53 \\
10.30 \\
8.94 \\
11.27 \\
8.77 \\
11.00\end{array}$ & $\begin{array}{r}120.4 \\
120.4 \\
107.8 \\
121.3 \\
114.2 \\
74.1 \\
99.8 \\
114.7 \\
114.3 \\
111.9 \\
128.1 \\
108.6 \\
111.8\end{array}$ & $\begin{array}{l}29.85 \\
29.85 \\
27.37 \\
29.51 \\
29.16 \\
16.52 \\
23.91 \\
28.57 \\
28.22 \\
27.90 \\
31.25 \\
27.01 \\
26.63\end{array}$ \\
\hline 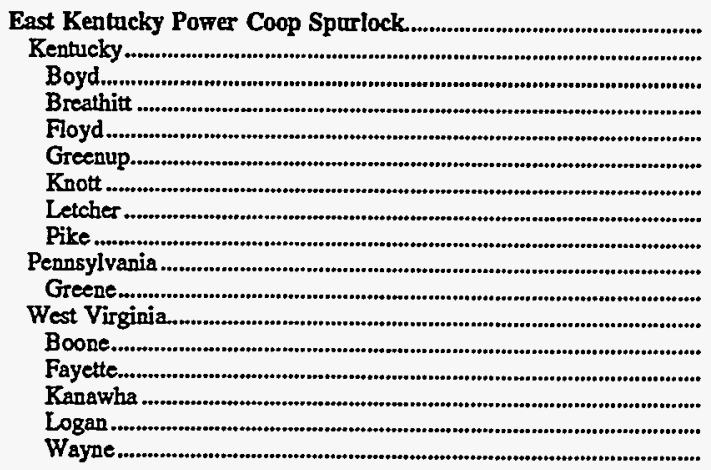 & $\begin{array}{r}2,203 \\
1,250 \\
407 \\
219 \\
96 \\
236 \\
157 \\
81 \\
54 \\
61 \\
61 \\
892 \\
24 \\
365 \\
79 \\
340 \\
84\end{array}$ & $\begin{array}{l}12,424 \\
12,461 \\
12,563 \\
12,223 \\
12,163 \\
12,379 \\
12,634 \\
13,118 \\
12,053 \\
13,210 \\
13,210 \\
12,319 \\
12,256 \\
12,333 \\
12,387 \\
12,318 \\
12,218\end{array}$ & $\begin{array}{l}.76 \\
.74 \\
.76 \\
.69 \\
.74 \\
.80 \\
.67 \\
.75 \\
.66 \\
1.54 \\
1.54 \\
.73 \\
.67 \\
.80 \\
.66 \\
.71 \\
.61\end{array}$ & $\begin{array}{l}.61 \\
.59 \\
.60 \\
.56 \\
.61 \\
.65 \\
.53 \\
.57 \\
.55 \\
1.17 \\
1.17 \\
.59 \\
.54 \\
.65 \\
.53 \\
.58 \\
.50\end{array}$ & $\begin{array}{r}10.55 \\
9.73 \\
8.80 \\
10.19 \\
10.49 \\
12.26 \\
8.49 \\
6.74 \\
10.63 \\
7.06 \\
7.06 \\
11.93 \\
12.97 \\
12.70 \\
10.94 \\
11.78 \\
9.81\end{array}$ & $\begin{array}{l}116.8 \\
117.9 \\
116.2 \\
121.2 \\
117.1 \\
114.5 \\
125.8 \\
114.7 \\
116.6 \\
107.2 \\
107.2 \\
116.0 \\
109.3 \\
114.8 \\
118.3 \\
115.3 \\
123.2\end{array}$ & $\begin{array}{l}29.03 \\
29.39 \\
29.19 \\
29.62 \\
28.49 \\
28.36 \\
31.78 \\
30.09 \\
28.11 \\
28.32 \\
28.32 \\
28.57 \\
26.80 \\
28.32 \\
29.32 \\
28.41 \\
30.11\end{array}$ \\
\hline Electric Energy Inc Joppa & 4,890 & 8,746 & .28 & 32 & 4.53 & 84.5 & 14.79 \\
\hline
\end{tabular}

Sce footnotes at end of table. 
Table B2. Profile of Coal Received at Table 1 Plants, 1995 (Continued)

\begin{tabular}{|c|c|c|c|c|c|c|c|}
\hline \multirow[b]{2}{*}{$\begin{array}{l}\text { Electric UtIllty Plant } \\
\text { Origin State } \\
\text { County }\end{array}$} & \multirow[b]{2}{*}{$\begin{array}{l}\text { Recelpts } \\
\text { (thousand } \\
\text { short tons) }\end{array}$} & \multicolumn{4}{|c|}{ Average Quality } & \multicolumn{2}{|c|}{$\begin{array}{l}\text { Average Delivered } \\
\text { Cost }\end{array}$} \\
\hline & & $\begin{array}{l}\text { Btu } \\
\text { (per } \\
\text { pound) }\end{array}$ & $\begin{array}{c}\text { Sulfur } \\
\text { (percent } \\
\text { by } \\
\text { welght) }\end{array}$ & $\begin{array}{l}\text { Sulfur } \\
\text { (pounds } \\
\text { per } \\
\text { MM Btu) }\end{array}$ & $\begin{array}{c}\text { Ash } \\
\text { (percent } \\
\text { by } \\
\text { welght) }\end{array}$ & $\begin{array}{l}\text { (cents } \\
\text { per } \\
\text { million } \\
\text { Bta) }\end{array}$ & $\begin{array}{l}\text { (dollars } \\
\text { per } \\
\text { short } \\
\text { ton) }\end{array}$ \\
\hline 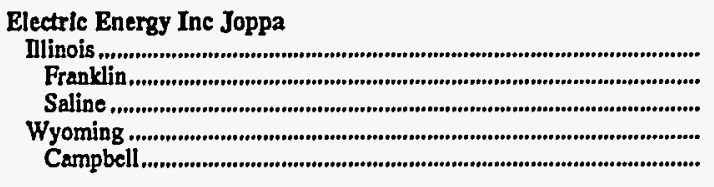 & $\begin{array}{r}96 \\
12 \\
84 \\
4,794 \\
4,794\end{array}$ & $\begin{array}{r}12,414 \\
12,308 \\
12,429 \\
8,673 \\
8,673\end{array}$ & $\begin{array}{r}1.65 \\
.77 \\
1.77 \\
.25 \\
.25\end{array}$ & $\begin{array}{r}1.33 \\
.63 \\
1.43 \\
.29 \\
.29\end{array}$ & $\begin{array}{l}7.92 \\
4.70 \\
8.38 \\
4.46 \\
4.46\end{array}$ & $\begin{array}{r}108.5 \\
108.5 \\
108.5 \\
83.8 \\
83.8\end{array}$ & $\begin{array}{l}26.94 \\
26.71 \\
26.97 \\
14.54 \\
14.54\end{array}$ \\
\hline 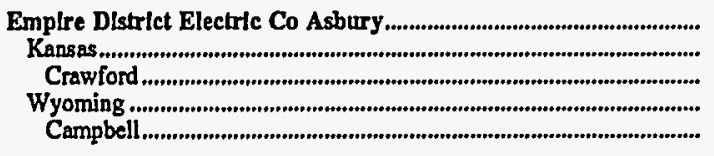 & $\begin{array}{l}860 \\
101 \\
101 \\
759 \\
759\end{array}$ & $\begin{array}{r}9,136 \\
11,811 \\
11,811 \\
8,781 \\
8,781\end{array}$ & $\begin{array}{r}.58 \\
3.42 \\
3.42 \\
.21 \\
.21\end{array}$ & $\begin{array}{r}.64 \\
2.89 \\
2.89 \\
.24 \\
.24\end{array}$ & $\begin{array}{r}5.58 \\
13.47 \\
13.47 \\
4.53 \\
4.53\end{array}$ & $\begin{array}{r}103.5 \\
125.8 \\
125.8 \\
99.5 \\
99.5\end{array}$ & $\begin{array}{l}18.90 \\
29.72 \\
29.72 \\
17.47 \\
17.47\end{array}$ \\
\hline 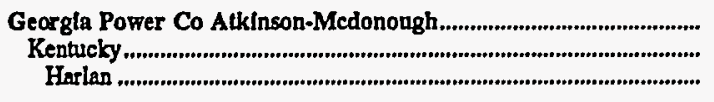 & $\begin{array}{l}1,202 \\
1,202 \\
1,202\end{array}$ & $\begin{array}{l}12,572 \\
12,572 \\
12,572\end{array}$ & $\begin{array}{l}.85 \\
.85 \\
.85\end{array}$ & $\begin{array}{l}.68 \\
.68 \\
.68\end{array}$ & $\begin{array}{l}9.74 \\
9.74 \\
9.74\end{array}$ & $\begin{array}{l}133.5 \\
133.5 \\
133.5\end{array}$ & $\begin{array}{l}33.56 \\
33.56 \\
33.56\end{array}$ \\
\hline 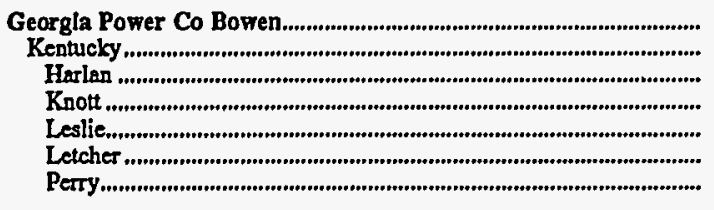 & $\begin{array}{r}7,545 \\
7,545 \\
427 \\
249 \\
4,173 \\
296 \\
2,400\end{array}$ & $\begin{array}{l}12,493 \\
12,493 \\
12,561 \\
12,289 \\
12,472 \\
12,835 \\
12,497\end{array}$ & $\begin{array}{r}1.04 \\
1.04 \\
.97 \\
1.02 \\
1.11 \\
.96 \\
.92\end{array}$ & $\begin{array}{l}.83 \\
.83 \\
.77 \\
.83 \\
.89 \\
.75 \\
.74\end{array}$ & $\begin{array}{r}9.90 \\
9.90 \\
9.54 \\
11.03 \\
10.07 \\
8.20 \\
9.74\end{array}$ & $\begin{array}{l}163.0 \\
163.0 \\
139.2 \\
141.3 \\
175.1 \\
137.7 \\
151.6\end{array}$ & $\begin{array}{l}40.72 \\
40.72 \\
34.97 \\
34.73 \\
43.68 \\
35.34 \\
37.90\end{array}$ \\
\hline 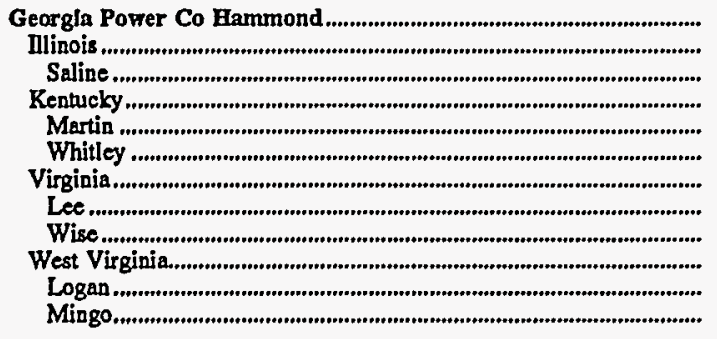 & $\begin{array}{r}1,037 \\
71 \\
71 \\
333 \\
294 \\
39 \\
450 \\
20 \\
430 \\
183 \\
79 \\
104\end{array}$ & $\begin{array}{l}12,552 \\
12,108 \\
12,108 \\
12,513 \\
12,415 \\
13,267 \\
12,647 \\
12,455 \\
12,656 \\
12,563 \\
12,753 \\
12,421\end{array}$ & $\begin{array}{r}.97 \\
1.16 \\
1.16 \\
.86 \\
.86 \\
.88 \\
1.15 \\
1.11 \\
1.15 \\
.66 \\
.66 \\
.65\end{array}$ & $\begin{array}{l}.77 \\
.96 \\
.96 \\
.69 \\
.69 \\
.66 \\
.91 \\
.89 \\
.91 \\
.52 \\
.52 \\
.53\end{array}$ & $\begin{array}{r}10.02 \\
5.99 \\
5.99 \\
9.08 \\
9.67 \\
4.60 \\
11.38 \\
11.22 \\
11.39 \\
9.96 \\
10.39 \\
9.63\end{array}$ & $\begin{array}{l}146.5 \\
140.6 \\
140.6 \\
143.5 \\
144.2 \\
138.4 \\
148.5 \\
184.2 \\
146.9 \\
149.3 \\
151.9 \\
147.4\end{array}$ & $\begin{array}{l}36.78 \\
34.04 \\
34.04 \\
35.90 \\
35.80 \\
36.72 \\
37.56 \\
45.88 \\
37.17 \\
37.53 \\
38.74 \\
36.62\end{array}$ \\
\hline 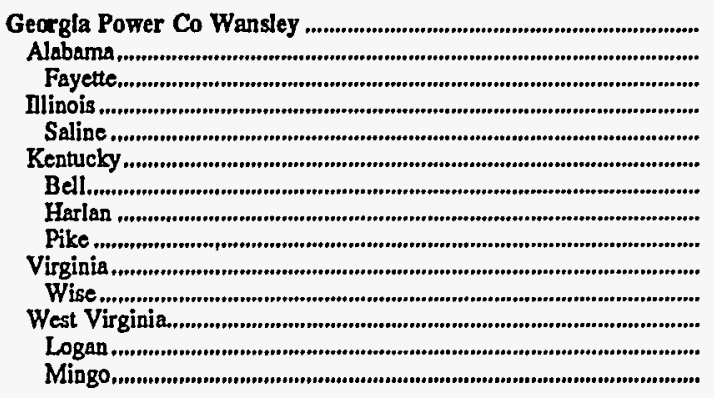 & $\begin{array}{r}2,801 \\
104 \\
104 \\
487 \\
487 \\
1,663 \\
9 \\
1,634 \\
20 \\
113 \\
113 \\
434 \\
30 \\
404\end{array}$ & $\begin{array}{l}12,722 \\
12,178 \\
12,178 \\
12,086 \\
12,086 \\
12,948 \\
11,913 \\
12,989 \\
10,001 \\
12,769 \\
12,769 \\
12,690 \\
12,748 \\
12,686\end{array}$ & $\begin{array}{r}.88 \\
1.85 \\
1.85 \\
1.11 \\
1.11 \\
.72 \\
.90 \\
.73 \\
.56 \\
.96 \\
.96 \\
.95 \\
.83 \\
.96\end{array}$ & $\begin{array}{r}.69 \\
1.52 \\
1.52 \\
.92 \\
.92 \\
.56 \\
.76 \\
.56 \\
.56 \\
.75 \\
.75 \\
.75 \\
.65 \\
.76\end{array}$ & $\begin{array}{r}8.40 \\
12.22 \\
12.22 \\
6.41 \\
6.41 \\
8.50 \\
10.14 \\
8.26 \\
27.14 \\
10.06 \\
10.06 \\
8.93 \\
10.37 \\
8.82\end{array}$ & $\begin{array}{l}189.4 \\
133.7 \\
133.7 \\
157.1 \\
157.1 \\
204.0 \\
205.3 \\
204.6 \\
132.5 \\
151.2 \\
151.2 \\
189.9 \\
154.0 \\
192.6\end{array}$ & $\begin{array}{l}48.20 \\
32.55 \\
32.55 \\
37.97 \\
37.97 \\
52.82 \\
48.91 \\
53.15 \\
26.50 \\
38.63 \\
38.63 \\
48.19 \\
39.26 \\
48.85\end{array}$ \\
\hline 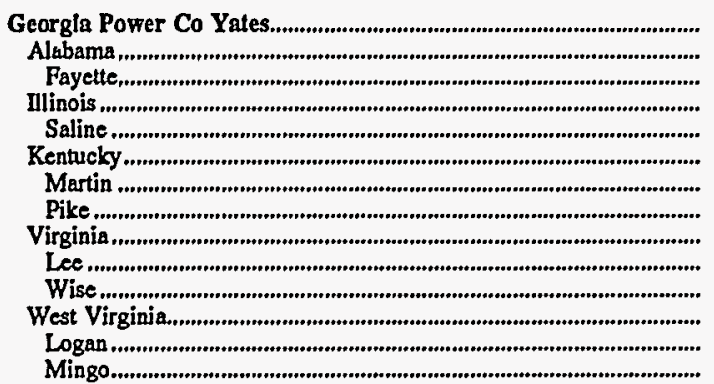 & $\begin{array}{r}1,235 \\
29 \\
29 \\
46 \\
46 \\
108 \\
50 \\
58 \\
682 \\
357 \\
325 \\
370 \\
174 \\
196\end{array}$ & $\begin{array}{l}12,534 \\
12,191 \\
12,191 \\
12,109 \\
12,109 \\
12,239 \\
12,126 \\
12,336 \\
12,608 \\
12,426 \\
12,809 \\
12,564 \\
12,813 \\
12,343\end{array}$ & $\begin{array}{r}.90 \\
1.89 \\
1.89 \\
1.12 \\
1.12 \\
.83 \\
.87 \\
.80 \\
.98 \\
1.10 \\
.84 \\
.67 \\
.67 \\
.68\end{array}$ & $\begin{array}{l}.72 \\
1.55 \\
1.55 \\
.92 \\
.92 \\
.68 \\
.72 \\
.65 \\
.78 \\
.89 \\
.66 \\
.53 \\
.52 \\
.55\end{array}$ & $\begin{array}{r}10.14 \\
11.96 \\
11.96 \\
6.72 \\
6.72 \\
10.94 \\
10.75 \\
11.10 \\
10.27 \\
11.17 \\
9.29 \\
9.94 \\
9.56 \\
10.27\end{array}$ & $\begin{array}{l}160.6 \\
132.4 \\
132.4 \\
146.9 \\
146.9 \\
155.2 \\
147.6 \\
161.6 \\
168.5 \\
189.8 \\
145.8 \\
151.2 \\
152.2 \\
150.3\end{array}$ & $\begin{array}{l}40.26 \\
32.28 \\
32.28 \\
35.58 \\
35.58 \\
37.99 \\
35.79 \\
39.87 \\
42.50 \\
47.18 \\
37.36 \\
37.99 \\
39.01 \\
37.10\end{array}$ \\
\hline
\end{tabular}

See footnotes at end of table. 
Table B2. Profile of Coal Received at Table 1 Plants, 1995 (Continued)

\begin{tabular}{|c|c|c|c|c|c|c|c|}
\hline \multirow{2}{*}{$\begin{array}{c}\text { Electric UtIIIty Plant } \\
\text { Origin State } \\
\text { County }\end{array}$} & \multirow{2}{*}{$\begin{array}{l}\text { Recelpts } \\
\text { (thousand } \\
\text { short tons) }\end{array}$} & \multicolumn{4}{|c|}{ Average Quallty } & \multicolumn{2}{|c|}{$\begin{array}{c}\text { Average Dellvered } \\
\text { Cost }\end{array}$} \\
\hline & & $\begin{array}{c}\text { Btu } \\
\text { (per } \\
\text { pound) }\end{array}$ & $\begin{array}{c}\text { Sulfur } \\
\text { (percent } \\
\text { by } \\
\text { welght) }\end{array}$ & $\begin{array}{c}\text { Sulfur } \\
\text { (pounds } \\
\text { per } \\
\text { MM Btu) }\end{array}$ & $\begin{array}{c}\text { Ash } \\
\text { (percent } \\
\text { by } \\
\text { welght) }\end{array}$ & $\begin{array}{l}\text { (cents } \\
\text { per } \\
\text { million } \\
\text { Btu) }\end{array}$ & $\begin{array}{l}\text { (dollars } \\
\text { per } \\
\text { short } \\
\text { ton) }\end{array}$ \\
\hline 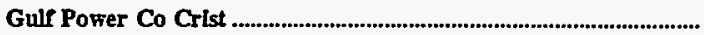 & 1,574 & 12,354 & 0.93 & 0.75 & 6.31 & 229.6 & 56.74 \\
\hline Illinois & 797 & 12,346 & .95 & .77 & 6.34 & 228.4 & 56.40 \\
\hline 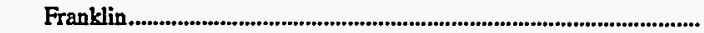 & 20 & 11,690 & 2.17 & 1.86 & 8.29 & 128.1 & 29.96 \\
\hline 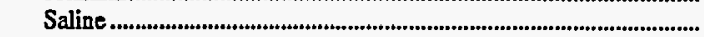 & 777 & 12,363 & .92 & .74 & 6.29 & 230.9 & 57.09 \\
\hline Imported & 777 & 12,363 & .92 & .74 & 6.29 & 230.9 & 57.09 \\
\hline 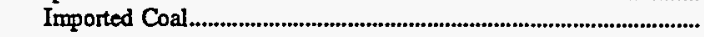 & 777 & 12,363 & .92 & .74 & 6.29 & 230.9 & 57.09 \\
\hline 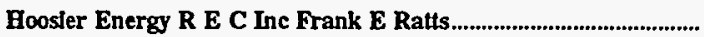 & 753 & 11,151 & 1.30 & 1.16 & $\mathbf{7 . 4 5}$ & 132.6 & 29.57 \\
\hline Indiana & 753 & 11,151 & 1.30 & 1.16 & 7.45 & 132.6 & 29.57 \\
\hline 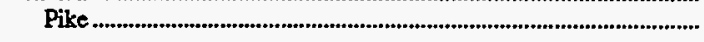 & 753 & 11,151 & 1.30 & 1.16 & 7.45 & 132.6 & 29.57 \\
\hline 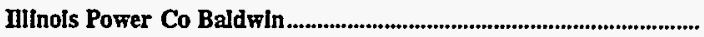 & 4,353 & 10,824 & 2.92 . & 2.70 & 10.16 & 109.7 & 23.75 \\
\hline 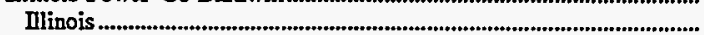 & 4,353 & 10,824 & 2.92 & 2.70 & 10.16 & 109.7 & 23.75 \\
\hline Peтту & 2,074 & 10,941 & 2.93 & 2.68 & 10.04 & 113.0 & 24.72 \\
\hline 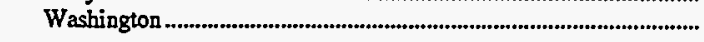 & 2,279 & 10,718 & 2.91 & 2.72 & 10.27 & 106.7 & 22.87 \\
\hline Illnols Power Co Hennepin & 583 & 10,703 & 293 & 2.74 & 10.32 & 113.5 & 24.29 \\
\hline Ilinois & 583 & 10,703 & 2.93 & 2.74 & 10.32 & 113.5 & 24.29 \\
\hline 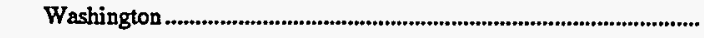 & 583 & 10,703 & 2.93 & 2.74 & 10.32 & 113.5 & 24.29 \\
\hline 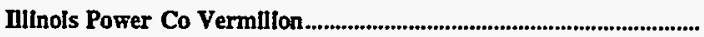 & 31 & 11,142 & 2.10 & 1.88 & 8.81 & 132.0 & 29.41 \\
\hline 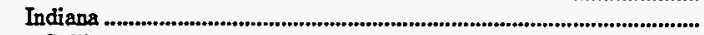 & 31 & 11,142 & 2.10 & 1.88 & 8.81 & 132.0 & 29.41 \\
\hline Sullivan & 31 & 11,142 & 2.10 & 1.88 & 8.81 & 132.0 & 29.41 \\
\hline Indlana \& Michigan Electric Co Tanners Creek............................... & 1,428 & 12,265 & 1.19 & 97 & 8.78 & 146.9 & 36.04 \\
\hline 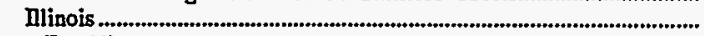 & 61 & 11,377 & 1.88 & 1.66 & 8.74 & 109.1 & 24.82 \\
\hline 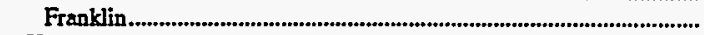 & 61 & 11,377 & 1.88 & 1.66 & 8.74 & 109.1 & 24.82 \\
\hline 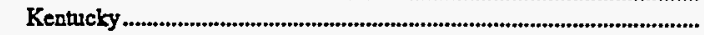 & 713 & 12,514 & 1.65 & 1.32 & 7.40 & 134.2 & 33.60 \\
\hline 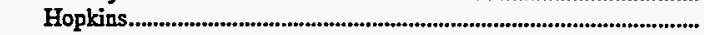 & 336 & 11,611 & 1.95 & 1.68 & 9.63 & 111.9 & 25.98 \\
\hline Letcher & 377 & 13,320 & 1.38 & 1.04 & 5.42 & 151.6 & 40.39 \\
\hline West Virginia & 553 & 12,684 & .70 & .56 & 11.34 & 168.8 & 42.82 \\
\hline 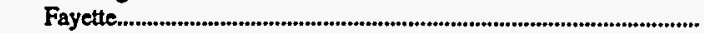 & 249 & 12,743 & .70 & .55 & 11.06 & 174.1 & 44.36 \\
\hline 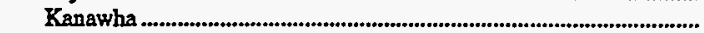 & 249 & 12,743 & .70 & .55 & 11.06 & 174.1 & 44.36 \\
\hline 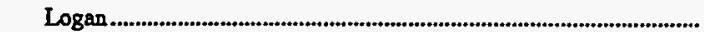 & 53 & 12,155 & .67 & .55 & 13.99 & 119.3 & 29.01 \\
\hline 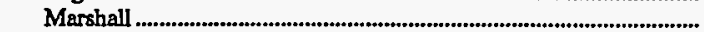 & 2 & 11,822 & 2.67 & 2.26 & 11.60 & 98.7 & 23.34 \\
\hline 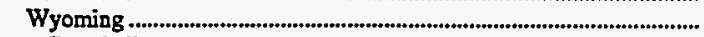 & 100 & 8,730 & .19 & .22 & 4.39 & 131.0 & 22.87 \\
\hline 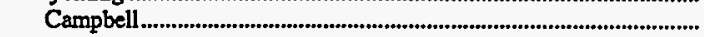 & 100 & 8,730 & .19 & .22 & 4.39 & 131.0 & 22.87 \\
\hline 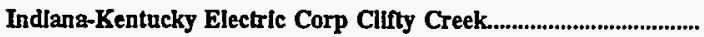 & 4,890 & 10,297 & 1.03 & 1.00 & 6.42 & 109.4 & 22.53 \\
\hline 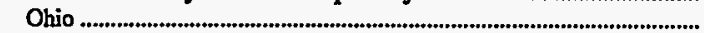 & 912 & 11,156 & 4.01 & 3.60 & 11.85 & 100.6 & 22.44 \\
\hline Belmont. & 93 & 12,213 & 4.40 & 3.60 & 10.18 & 94.4 & 23.05 \\
\hline 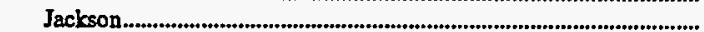 & 819 & 11,036 & 3.97 & 3.60 & 12.04 & 101.4 & 22.37 \\
\hline Virginia & 1,014 & 13,792 & .73 & .53 & 6.06 & 152.4 & 42.04 \\
\hline Buchanan & 1,014 & 13,792 & .73 & .53 & 6.06 & 152.4 & 42.04 \\
\hline 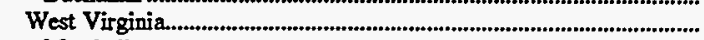 & 7 & 12,050 & 3.96 & 3.29 & 13.57 & 110.3 & 26.58 \\
\hline 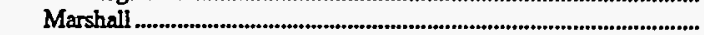 & 7 & 12,050 & 3.96 & 3.29 & 13.57 & 110.3 & 26.58 \\
\hline Wyoming & 2,957 & 8,830 & .20 & .23 & 4.86 & 89.8 & 15.85 \\
\hline Campbell & 95 & 8,774 & .19 & .22 & 4.26 & 81.9 & 14.37 \\
\hline Converse & 2,862 & 8,831 & .20 & .23 & 4.88 & 90.0 & 15.90 \\
\hline 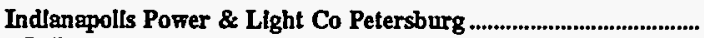 & 4,598 & 11,099 & 2.42 & 2.18 & 8.95 & 101.1 & 22.45 \\
\hline Indiana & 4,598 & 11,099 & 2.42 & 2.18 & 8.95 & 101.1 & 22.45 \\
\hline 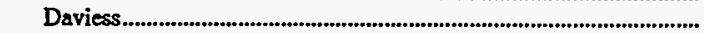 & 1,901 & 11,319 & 2.24 & 1.98 & 8.67 & 92.7 & 20.98 \\
\hline 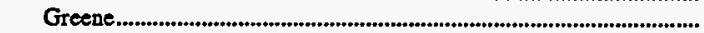 & 4 & 11,531 & 2.44 & 2.12 & 8.03 & 88.7 & 20.46 \\
\hline Knox & 360 & 10,871 & .63 & .58 & 8.35 & 120.4 & 26.18 \\
\hline 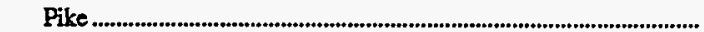 & 156 & 11,114 & 2.56 & 2.31 & 8.62 & 96.5 & 21.44 \\
\hline 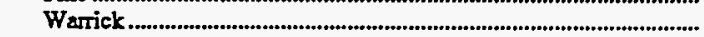 & 2,177 & 10,942 & 2.86 & 2.62 & 9.32 & 106.0 & 23.19 \\
\hline Indlanapolis Power \& Light Co Pritchard........................................... & 340 & 11,368 & 1.24 & 1.09 & 7.31 & 112.0 & 25.45 \\
\hline Indiana & 340 & 11,368 & 1.24 & 1.09 & 7.31 & 112.0 & 25.45 \\
\hline 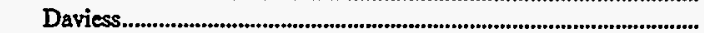 & 52 & 11,169 & 1.31 & 1.17 & 8.04 & 109.8 & 24.52 \\
\hline 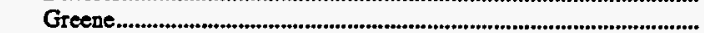 & 147 & 11,487 & 1.28 & 1.11 & 6.99 & 111.3 & 25.57 \\
\hline Owen & 141 & 11,316 & 1.17 & 1.03 & 7.37 & 113.4 & 25.67 \\
\hline 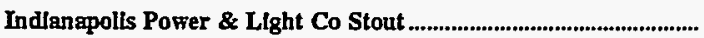 & 1,335 & 11,255 & 1.46 & 1.30 & 8.11 & 1135 & 25.54 \\
\hline
\end{tabular}

See footnotes at end of table. 
Table B2. Profile of Coal Received at Table 1 Plants, 1995 (Continued)

\begin{tabular}{|c|c|c|c|c|c|c|c|}
\hline \multirow{2}{*}{$\begin{array}{l}\text { Electric Uttlity Plant } \\
\text { Origin State } \\
\text { County }\end{array}$} & \multirow{2}{*}{$\begin{array}{l}\text { Recelpts } \\
\text { (thousand } \\
\text { short tons) }\end{array}$} & \multicolumn{4}{|c|}{ Average Quallty } & \multicolumn{2}{|c|}{$\begin{array}{l}\text { Average Dellvered } \\
\text { Cost }\end{array}$} \\
\hline & & $\begin{array}{l}\text { Btu } \\
\text { (per } \\
\text { pound) }\end{array}$ & $\begin{array}{l}\text { Sulfur } \\
\text { (percent } \\
\text { by } \\
\text { welght) }\end{array}$ & $\begin{array}{l}\text { Sulfur } \\
\text { (pounds } \\
\text { per } \\
\text { MM Btu) }\end{array}$ & $\begin{array}{l}\text { Ash } \\
\text { (percent } \\
\text { by } \\
\text { weight) }\end{array}$ & $\begin{array}{l}\text { (cents } \\
\text { per } \\
\text { millilon } \\
\text { Btu) }\end{array}$ & $\begin{array}{l}\text { (dollars } \\
\text { per } \\
\text { short } \\
\text { ton) }\end{array}$ \\
\hline \multicolumn{8}{|l|}{ Indlanapolis Power \& Llght Co Stout } \\
\hline 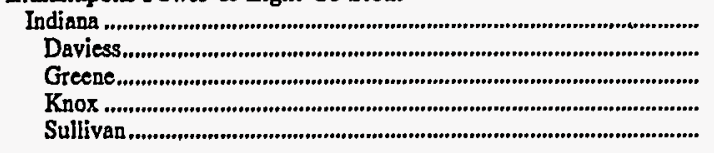 & $\begin{array}{r}1,335 \\
505 \\
665 \\
42 \\
123\end{array}$ & $\begin{array}{l}11,255 \\
11,151 \\
11,392 \\
11,199 \\
10,956\end{array}$ & $\begin{array}{l}1.46 \\
1.49 \\
1.48 \\
1.43 \\
1.28\end{array}$ & $\begin{array}{l}1.30 \\
1.33 \\
1.30 \\
1.28 \\
1.17\end{array}$ & $\begin{array}{r}8.11 \\
8.48 \\
7.47 \\
8.22 \\
10.06\end{array}$ & $\begin{array}{r}113.5 \\
111.9 \\
118.0 \\
115.6 \\
93.7\end{array}$ & $\begin{array}{l}25.54 \\
24.95 \\
26.88 \\
25.90 \\
20.54\end{array}$ \\
\hline 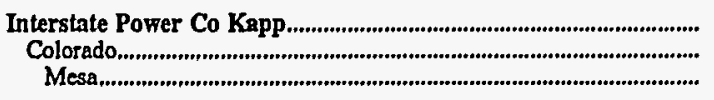 & $\begin{array}{l}372 \\
372 \\
372\end{array}$ & $\begin{array}{l}11,334 \\
11,334 \\
11,334\end{array}$ & $\begin{array}{l}.58 \\
.58 \\
.58\end{array}$ & $\begin{array}{l}.52 \\
.52 \\
.52\end{array}$ & $\begin{array}{l}11.32 \\
11.32 \\
11.32\end{array}$ & $\begin{array}{l}126.9 \\
126.9 \\
126.9\end{array}$ & $\begin{array}{l}28.78 \\
28.78 \\
28.78\end{array}$ \\
\hline 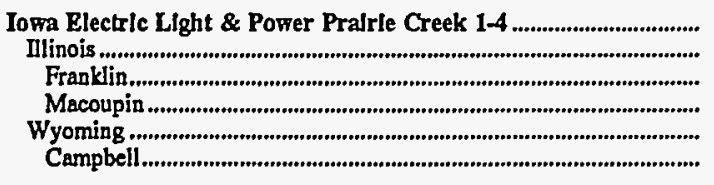 & $\begin{array}{r}846 \\
117 \\
103 \\
14 \\
729 \\
729\end{array}$ & $\begin{array}{r}8,868 \\
11,459 \\
11,603 \\
10,401 \\
8,452 \\
8,452\end{array}$ & $\begin{array}{r}.56 \\
1.96 \\
2.10 \\
.92 \\
.33 \\
.33\end{array}$ & $\begin{array}{r}.63 \\
1.71 \\
1.81 \\
.88 \\
.39 \\
.39\end{array}$ & $\begin{array}{l}5.66 \\
8.70 \\
8.78 \\
8.06 \\
5.17 \\
5.17\end{array}$ & $\begin{array}{l}112.7 \\
121.6 \\
121.8 \\
119.4 \\
110.7 \\
110.7\end{array}$ & $\begin{array}{l}19.98 \\
27.86 \\
28.27 \\
24.83 \\
18.72 \\
18.72\end{array}$ \\
\hline 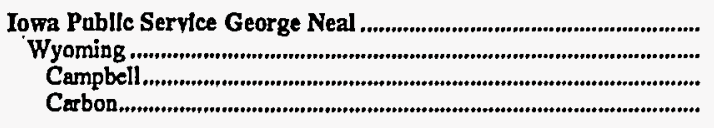 & $\begin{array}{r}5,934 \\
5,934 \\
5,316 \\
618\end{array}$ & $\begin{array}{r}8,728 \\
8,728 \\
8,526 \\
10,467\end{array}$ & $\begin{array}{l}.38 \\
.38 \\
.37 \\
.45\end{array}$ & $\begin{array}{l}.44 \\
.44 \\
.44 \\
.43\end{array}$ & $\begin{array}{l}5.31 \\
5.31 \\
5.14 \\
6.79\end{array}$ & $\begin{array}{r}81.4 \\
81.4 \\
76.9 \\
113.3\end{array}$ & $\begin{array}{l}14.21 \\
14.21 \\
13.11 \\
23.72\end{array}$ \\
\hline 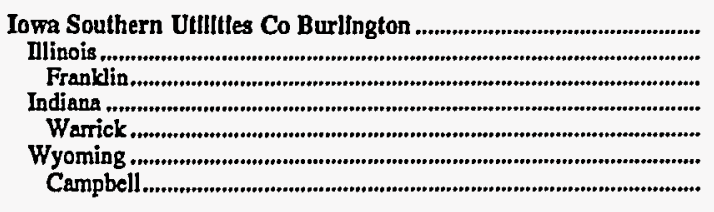 & $\begin{array}{r}482 \\
179 \\
179 \\
18 \\
18 \\
285 \\
285\end{array}$ & $\begin{array}{r}9,691 \\
11,589 \\
11,589 \\
11,434 \\
11,434 \\
8,389 \\
8,389\end{array}$ & $\begin{array}{r}1.05 \\
2.02 \\
2.02 \\
2.68 \\
2.68 \\
.33 \\
.33\end{array}$ & $\begin{array}{r}1.08 \\
1.74 \\
1.74 \\
2.34 \\
2.34 \\
.40 \\
.40\end{array}$ & $\begin{array}{l}6.46 \\
8.81 \\
8.81 \\
8.33 \\
8.33 \\
4.86 \\
4.86\end{array}$ & $\begin{array}{r}99.5 \\
105.4 \\
105.4 \\
132.2 \\
132.2 \\
91.7 \\
91.7\end{array}$ & $\begin{array}{l}19.29 \\
24.42 \\
24.42 \\
30.23 \\
30.23 \\
15.38 \\
15.38\end{array}$ \\
\hline 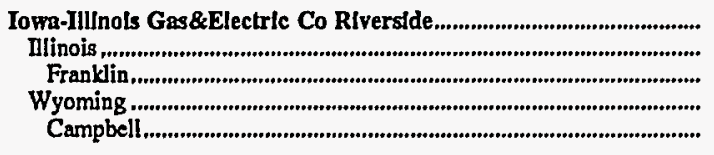 & $\begin{array}{r}348 \\
55 \\
55 \\
293 \\
293\end{array}$ & $\begin{array}{r}8,779 \\
11,281 \\
11,281 \\
8,309 \\
8,309\end{array}$ & $\begin{array}{r}.67 \\
1.96 \\
1.96 \\
.43 \\
.43\end{array}$ & $\begin{array}{r}.76 \\
1.74 \\
1.74 \\
.51 \\
.51\end{array}$ & $\begin{array}{l}6.65 \\
8.67 \\
8.67 \\
6.28 \\
6.28\end{array}$ & $\begin{array}{l}\mathbf{1 2 3 . 1} \\
108.2 \\
108.2 \\
127.0 \\
127.0\end{array}$ & $\begin{array}{l}21.62 \\
24.41 \\
24.41 \\
21.10 \\
21.10\end{array}$ \\
\hline 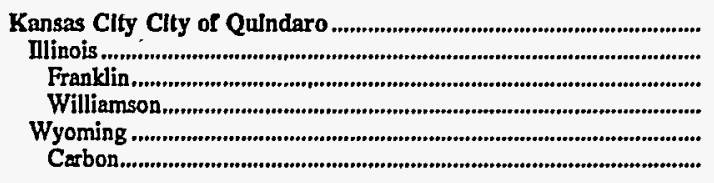 & $\begin{array}{r}402 \\
138 \\
9 \\
128 \\
264 \\
264\end{array}$ & $\begin{array}{l}10,817 \\
11,521 \\
11,280 \\
11,538 \\
10,450 \\
10,450\end{array}$ & $\begin{array}{r}1.07 \\
2.33 \\
1.90 \\
2.36 \\
.41 \\
.41\end{array}$ & $\begin{array}{r}.99 \\
2.02 \\
1.68 \\
2.04 \\
.39 \\
.39\end{array}$ & $\begin{array}{r}7.84 \\
10.25 \\
10.05 \\
10.26 \\
6.59 \\
6.59\end{array}$ & $\begin{array}{l}207.4 \\
339.2 \\
112.5 \\
355.5 \\
131.7 \\
131.7\end{array}$ & $\begin{array}{l}44.88 \\
78.16 \\
25.38 \\
82.05 \\
27.53 \\
27.53\end{array}$ \\
\hline 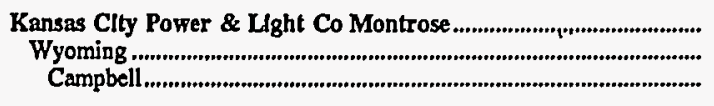 & $\begin{array}{l}1,653 \\
1,653 \\
1,653\end{array}$ & $\begin{array}{l}8,674 \\
8,674 \\
8,674\end{array}$ & $\begin{array}{l}.21 \\
.21 \\
.21\end{array}$ & $\begin{array}{l}.24 \\
.24 \\
.24\end{array}$ & $\begin{array}{l}5.02 \\
5.02 \\
5.02\end{array}$ & $\begin{array}{l}97.5 \\
97.5 \\
97.5\end{array}$ & $\begin{array}{l}16.91 \\
16.91 \\
16.91\end{array}$ \\
\hline 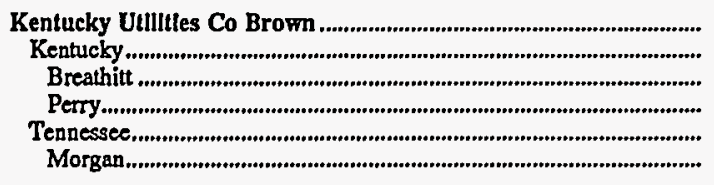 & $\begin{array}{r}1,031 \\
1,022 \\
387 \\
635 \\
9 \\
9\end{array}$ & $\begin{array}{l}11,913 \\
11,905 \\
11,845 \\
11,943 \\
12,791 \\
12,791\end{array}$ & $\begin{array}{l}1.29 \\
1.28 \\
1.05 \\
1.42 \\
2.54 \\
2.54\end{array}$ & $\begin{array}{r}1.08 \\
1.07 \\
.89 \\
1.19 \\
1.99 \\
1.99\end{array}$ & $\begin{array}{l}11.72 \\
11.72 \\
11.56 \\
11.82 \\
11.56 \\
11.56\end{array}$ & $\begin{array}{l}118.3 \\
118.3 \\
118.2 \\
118.3 \\
115.8 \\
115.8\end{array}$ & $\begin{array}{l}28.18 \\
28.17 \\
28.00 \\
28.27 \\
29.62 \\
29.62\end{array}$ \\
\hline 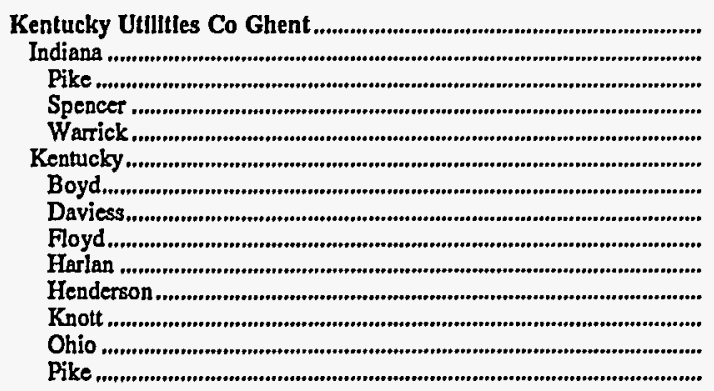 & $\begin{array}{r}4,728 \\
285 \\
178 \\
90 \\
17 \\
1,837 \\
23 \\
157 \\
213 \\
327 \\
250 \\
334 \\
80 \\
452\end{array}$ & $\begin{array}{l}12,234 \\
11,204 \\
11,331 \\
10,976 \\
11,075 \\
12,060 \\
11,864 \\
11,178 \\
12,155 \\
12,589 \\
11,228 \\
12,524 \\
11,166 \\
12,225\end{array}$ & $\begin{array}{r}1.38 \\
2.97 \\
3.21 \\
2.44 \\
3.13 \\
1.28 \\
.65 \\
2.91 \\
.66 \\
.73 \\
2.88 \\
.67 \\
3.32 \\
.66\end{array}$ & $\begin{array}{r}1.13 \\
2.65 \\
2.83 \\
2.23 \\
2.83 \\
1.07 \\
.55 \\
2.60 \\
.54 \\
.58 \\
2.56 \\
.54 \\
2.98 \\
.54\end{array}$ & $\begin{array}{r}9.92 \\
9.37 \\
9.19 \\
9.61 \\
10.08 \\
9.53 \\
10.59 \\
9.66 \\
11.71 \\
8.37 \\
9.16 \\
8.81 \\
10.28 \\
9.83\end{array}$ & $\begin{array}{r}117.3 \\
94.5 \\
94.5 \\
96.5 \\
83.6 \\
125.7 \\
121.2 \\
95.6 \\
121.3 \\
136.7 \\
101.2 \\
143.5 \\
81.6 \\
135.3\end{array}$ & $\begin{array}{l}28.70 \\
21.17 \\
21.42 \\
21.18 \\
18.51 \\
30.31 \\
28.77 \\
21.38 \\
29.49 \\
34.43 \\
22.73 \\
35.94 \\
18.23 \\
33.09\end{array}$ \\
\hline
\end{tabular}

See footnotes at end of table. 
Table B2. Profile of Coal Received at Table 1 Plants, 1995 (Continued)

\begin{tabular}{|c|c|c|c|c|c|c|c|}
\hline \multirow{2}{*}{$\begin{array}{l}\text { Electric Utulty Plant } \\
\text { Orlgin State } \\
\text { County }\end{array}$} & \multirow{2}{*}{$\begin{array}{l}\text { Recelpts } \\
\text { (thousand } \\
\text { short tons) }\end{array}$} & \multicolumn{4}{|c|}{ Average Quallty } & \multicolumn{2}{|c|}{$\begin{array}{l}\text { Average Dellvered } \\
\text { Cost }\end{array}$} \\
\hline & & $\begin{array}{l}\text { Btu } \\
\text { (per } \\
\text { pound) }\end{array}$ & $\begin{array}{l}\text { Sulfur } \\
\text { (percent } \\
\text { by } \\
\text { melght) }\end{array}$ & $\begin{array}{c}\text { Sulfur } \\
\text { (pounds } \\
\text { per } \\
\text { MM Btu) }\end{array}$ & $\begin{array}{l}\text { Ash } \\
\text { (percent } \\
\text { by } \\
\text { welght) }\end{array}$ & $\begin{array}{l}\text { (cents } \\
\text { per } \\
\text { million } \\
\text { Btu) }\end{array}$ & $\begin{array}{l}\text { (dollars } \\
\text { per } \\
\text { short } \\
\text { ton) }\end{array}$ \\
\hline \multicolumn{8}{|l|}{ Kentucky UtIIttes Co Ghent } \\
\hline Pennsylvania & 198 & 13,228 & 2.50 & 1.89 & 8.16 & 102.8 & 27.20 \\
\hline 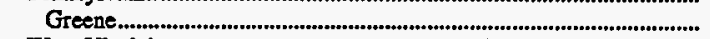 & 198 & 13,228 & 2.50 & 1.89 & 8.16 & 102.8 & 27.20 \\
\hline 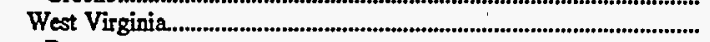 & 2,408 & 12,407 & 1.18 & .95 & 10.42 & 114.8 & 28.48 \\
\hline 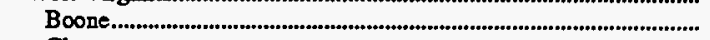 & 43 & 12,430 & .68 & .55 & 11.18 & 118.3 & 29.40 \\
\hline 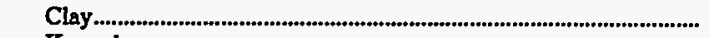 & 43 & 12,073 & .69 & .57 & 12.10 & 126.3 & 30.50 \\
\hline Kanawha & 821 & 12,657 & .70 & .55 & 10.51 & 120.2 & 30.41 \\
\hline Logan & 345 & 12,253 & .67 & .54 & 11.89 & 124.0 & 30.40 \\
\hline Marshall & 436 & 12,339 & 3.46 & 2.80 & 10.17 & 84.0 & 20.73 \\
\hline 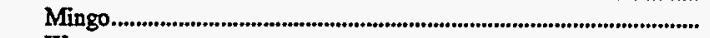 & 398 & 12,298 & .68 & .55 & 9.78 & 119.6 & 29.41 \\
\hline 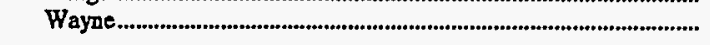 & 322 & 12,201 & .62 & .51 & 9.45 & 124.7 & 30.43 \\
\hline Kentucky Uttlties Co Green Rlver & 372 & 11,605 & 249 & 2.14 & 8.36 & 103.7 & 24.08 \\
\hline 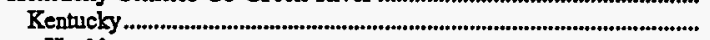 & 372 & 11,605 & 2.49 & 2.14 & 8.36 & 103.7 & 24.08 \\
\hline 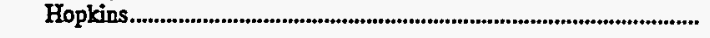 & 372 & 11,605 & 2.49 & 2.14 & 8.36 & 103.7 & 24.08 \\
\hline Metropolltan Edison Co Portland & 496 & 13,111 & 1.88 & 1.43 & $\mathbf{7 . 4 7}$ & 136.1 & $\mathbf{3 5 . 7 0}$ \\
\hline 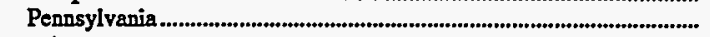 & 23 & 12,732 & 1.85 & 1.46 & 8.81 & 166.1 & 42.29 \\
\hline Armstrong & 15 & 12,852 & 2.04 & 1.58 & 8.97 & 166.9 & 42.90 \\
\hline 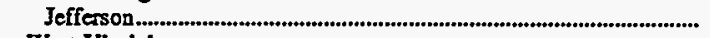 & 8 & 12,500 & 1.50 & 1.20 & 8.50 & 164.5 & 41.12 \\
\hline 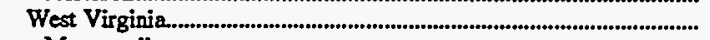 & 473 & 13,129 & 1.88 & 1.43 & 7.40 & 134.7 & 35.38 \\
\hline 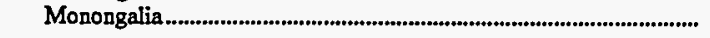 & 473 & 13,129 & 1.88 & 1.43 & 7.40 & 134.7 & 35.38 \\
\hline Mlssdsslppl Power Co Watson & 1,247 & 12,436 & 233 & 1.87 & 8.86 & 123.2 & 30.65 \\
\hline 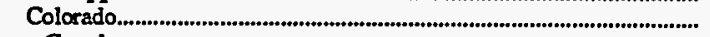 & 11 & 11,972 & .50 & .42 & 7.91 & 145.8 & 34.91 \\
\hline Gunnison & 11 & 11,972 & .50 & .42 & 7.91 & 145.8 & 34.91 \\
\hline Illinois & 1,236 & 12,440 & 2.35 & 1.89 & 8.86 & 123.0 & 30.61 \\
\hline Gallatin & 765 & 12,678 & 2.73 & 2.15 & 9.00 & 120.0 & 30.44 \\
\hline 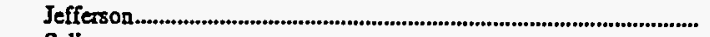 & 10 & 12,120 & .83 & .68 & 5.03 & 142.8 & 34.61 \\
\hline Saline & 460 & 12,052 & 1.75 & 1.45 & 8.73 & 127.8 & 30.81 \\
\hline 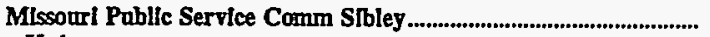 & 1,275 & 10,103 & .43 & .42 & 5.63 & 100.8 & 20.36 \\
\hline 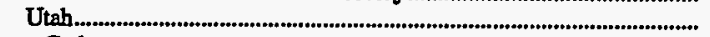 & 56 & 11,484 & .34 & .30 & 8.05 & 118.4 & 27.19 \\
\hline 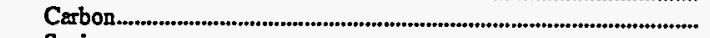 & 22 & 11,573 & .37 & .32 & 8.99 & 118.8 & 27.50 \\
\hline 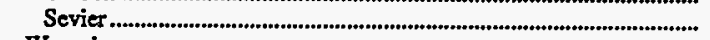 & 33 & 11,424 & .32 & .28 & 7.41 & 118.1 & 26.98 \\
\hline Wyoming & 1,219 & 10,040 & .43 & .43 & 5.52 & 99.9 & 20.05 \\
\hline 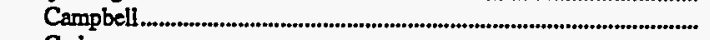 & 200 & 8,747 & .22 & .26 & 4.59 & 70.9 & 12.41 \\
\hline 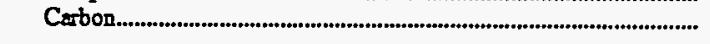 & 1,019 & 10,294 & .47 & .46 & 5.70 & 104.7 & 21.56 \\
\hline Monongahela Power Co Albright & 467 & 12,452 & 1.65 & 1.32 & 1244 & 96.9 & 24.13 \\
\hline 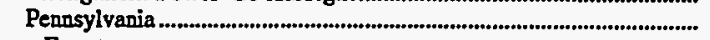 & 65 & 12,217 & 1.70 & 1.39 & 13.02 & 94.8 & 23.15 \\
\hline 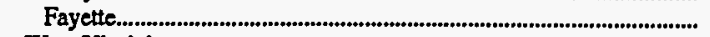 & 65 & 12,217 & 1.70 & 1.39 & 13.02 & 94.8 & 23.15 \\
\hline 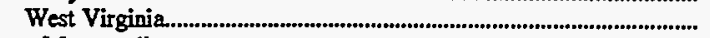 & 401 & 12,491 & 1.64 & 1.31 & 12.34 & 97.2 & 24.29 \\
\hline 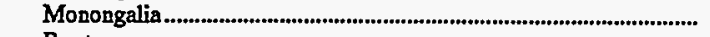 & 64 & 12,154 & 1.70 & 1.40 & 13.46 & 94.2 & 22.89 \\
\hline Preston & 337 & 12,555 & 1.63 & 1.30 & 12.13 & 97.8 & 24.56 \\
\hline 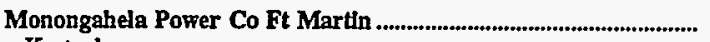 & 1,946 & 12,736 & 1.59 & 1.25 & 10.34 & 148.7 & 37.88 \\
\hline 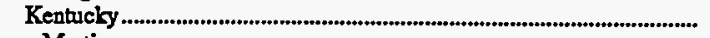 & 471 & 12,651 & .83 & .66 & 8.45 & 188.7 & 47.75 \\
\hline Martin & 471 & 12,651 & .83 & .66 & 8.45 & 188.7 & 47.75 \\
\hline 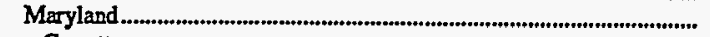 & 285 & 12,732 & 1.52 & 1.20 & 13.41 & 134.9 & 34.34 \\
\hline 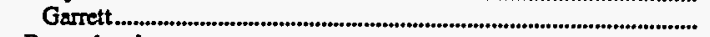 & 285 & 12,732 & 1.52 & 1.20 & 13.41 & 134.9 & 34.34 \\
\hline 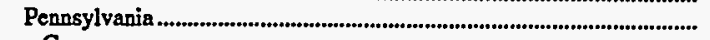 & 57 & 12,902 & 1.87 & 1.45 & 9.60 & 130.6 & 33.70 \\
\hline 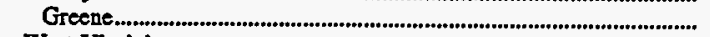 & 57 & 12,902 & 1.87 & 1.45 & 9.60 & 130.6 & 33.70 \\
\hline 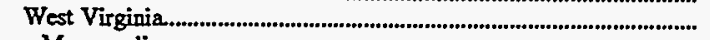 & 1,133 & 12,764 & 1.90 & 1.49 & 10.38 & 136.6 & 34.88 \\
\hline 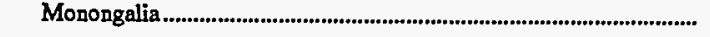 & 1,133 & 12,764 & 1.90 & 1.49 & 10.38 & 136.6 & 34.88 \\
\hline 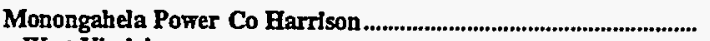 & 4,992 & 12,483 & 3.48 & 2.79 & 12.30 & 112.0 & 27.95 \\
\hline 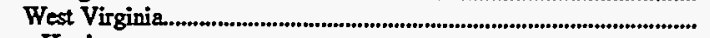 & 4,992 & 12,483 & 3.48 & 2.79 & 12.30 & 112.0 & 27.95 \\
\hline 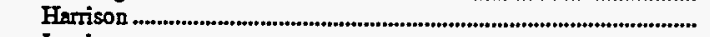 & 4,351 & 12,457 & 3.58 & 2.88 & 12.56 & 113.6 & 28.30 \\
\hline 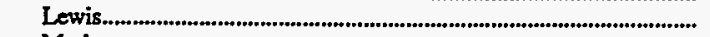 & 30 & 12,577 & 2.99 & 2.38 & 11.64 & 92.8 & 23.35 \\
\hline 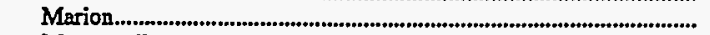 & 84 & 12,370 & 3.54 & 2.86 & 12.68 & 87.3 & 21.60 \\
\hline 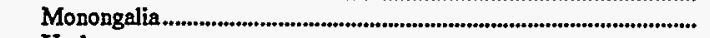 & 446 & 12,768 & 2.58 & 2.02 & 9.62 & 107.5 & 27.45 \\
\hline Upshur & 81 & 12,373 & 3.18 & 2.57 & 12.44 & 81.8 & 20.25 \\
\hline 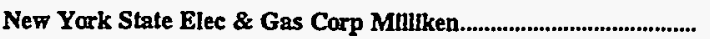 & 716 & 13,035 & 200 & 1.53 & 7.65 & 130.4 & 33.99 \\
\hline
\end{tabular}

See footnotes at end of table. 
Table B2. Profile of Coal Received at Table 1 Plants, 1995 (Continued)

\begin{tabular}{|c|c|c|c|c|c|c|c|}
\hline \multirow{2}{*}{$\begin{array}{l}\text { Electrie Utillty Plant } \\
\text { Origin State } \\
\text { County }\end{array}$} & \multirow{2}{*}{$\begin{array}{l}\text { Recelpts } \\
\text { (thousand } \\
\text { short tons) }\end{array}$} & \multicolumn{4}{|c|}{ Average Quallty } & \multicolumn{2}{|c|}{$\begin{array}{c}\text { Average Dellvered } \\
\text { Cost }\end{array}$} \\
\hline & & $\begin{array}{l}\text { Btu } \\
\text { (per } \\
\text { pound) }\end{array}$ & $\begin{array}{l}\text { Sulfur } \\
\text { (percent } \\
\text { by } \\
\text { melght) }\end{array}$ & $\begin{array}{l}\text { Sulfur } \\
\text { (pounds } \\
\text { per } \\
\text { MM Btu) }\end{array}$ & $\begin{array}{l}\text { Ash } \\
\text { (percent } \\
\text { by } \\
\text { weight) }\end{array}$ & $\begin{array}{l}\text { (cents } \\
\text { per } \\
\text { millilon } \\
\text { Btu) }\end{array}$ & $\begin{array}{l}\text { (dollars } \\
\text { per } \\
\text { short } \\
\text { ton) }\end{array}$ \\
\hline 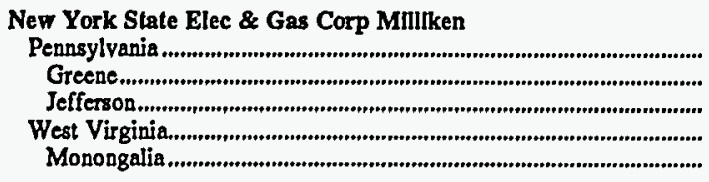 & $\begin{array}{r}239 \\
232 \\
8 \\
477 \\
477\end{array}$ & $\begin{array}{l}13,013 \\
13,023 \\
12,693 \\
13,046 \\
13,046\end{array}$ & $\begin{array}{l}1.56 \\
1.54 \\
2.06 \\
2.21 \\
2.21\end{array}$ & $\begin{array}{l}1.20 \\
1.19 \\
1.62 \\
1.70 \\
1.70\end{array}$ & $\begin{array}{r}6.97 \\
6.80 \\
12.10 \\
7.99 \\
7.99\end{array}$ & $\begin{array}{l}134.0 \\
133.7 \\
143.2 \\
128.6 \\
128.6\end{array}$ & $\begin{array}{l}34.87 \\
34.82 \\
36.35 \\
33.55 \\
33.55\end{array}$ \\
\hline 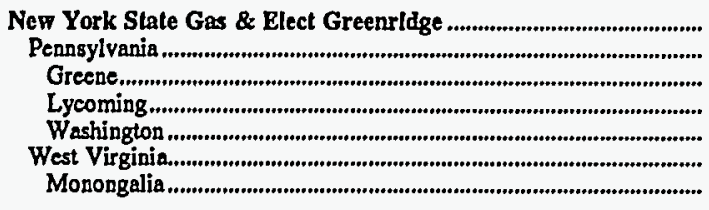 & $\begin{array}{r}242 \\
108 \\
67 \\
37 \\
5 \\
133 \\
133\end{array}$ & $\begin{array}{l}13,005 \\
12,589 \\
12,869 \\
11,976 \\
13,367 \\
13,344 \\
13,344\end{array}$ & $\begin{array}{r}1.80 \\
1.30 \\
1.51 \\
.90 \\
1.52 \\
2.21 \\
2.21\end{array}$ & $\begin{array}{r}1.39 \\
1.04 \\
1.17 \\
.75 \\
1.14 \\
1.66 \\
1.66\end{array}$ & $\begin{array}{r}8.54 \\
10.78 \\
7.28 \\
17.64 \\
7.00 \\
6.72 \\
6.72\end{array}$ & $\begin{array}{l}131.1 \\
133.8 \\
133.1 \\
133.6 \\
143.3 \\
129.1 \\
129.1\end{array}$ & $\begin{array}{r}34.10 \\
33.68 \\
34.26 \\
32.00 \\
38.31 \\
-34.45 \\
34.45\end{array}$ \\
\hline 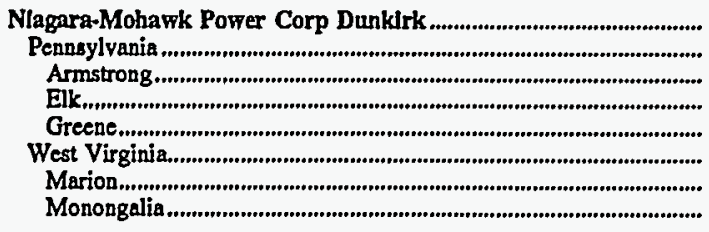 & $\begin{array}{r}1,356 \\
1,043 \\
49 \\
34 \\
960 \\
313 \\
17 \\
296\end{array}$ & $\begin{array}{l}13,044 \\
12,969 \\
13,052 \\
11,256 \\
13,026 \\
13,294 \\
13,143 \\
13,303\end{array}$ & $\begin{array}{l}2.06 \\
1.92 \\
2.38 \\
1.03 \\
1.93 \\
2.50 \\
2.50 \\
2.50\end{array}$ & $\begin{array}{r}1.58 \\
1.48 \\
1.83 \\
.92 \\
1.48 \\
1.88 \\
1.90 \\
1.88\end{array}$ & $\begin{array}{r}8.30 \\
8.57 \\
7.02 \\
13.00 \\
8.49 \\
7.40 \\
7.95 \\
7.37\end{array}$ & $\begin{array}{l}126.6 \\
126.8 \\
136.0 \\
122.1 \\
126.5 \\
126.0 \\
129.9 \\
125.8\end{array}$ & $\begin{array}{l}33.03 \\
32.89 \\
35.50 \\
27.49 \\
32.95 \\
33.51 \\
34.15 \\
33.48\end{array}$ \\
\hline 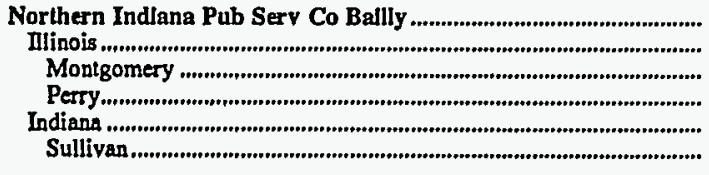 & $\begin{array}{r}1,336 \\
1,227 \\
79 \\
1,148 \\
109 \\
109\end{array}$ & $\begin{array}{l}10,970 \\
10,968 \\
10,750 \\
10,984 \\
10,993 \\
10,993\end{array}$ & $\begin{array}{l}2.94 \\
3.01 \\
3.28 \\
2.99 \\
2.08 \\
2.08\end{array}$ & $\begin{array}{l}2.68 \\
2.75 \\
3.05 \\
2.72 \\
1.90 \\
1.90\end{array}$ & $\begin{array}{r}9.99 \\
10.04 \\
8.28 \\
10.16 \\
9.45 \\
9.45\end{array}$ & $\begin{array}{l}137.6 \\
139.5 \\
113.1 \\
141.2 \\
116.4 \\
116.4\end{array}$ & $\begin{array}{l}30.18 \\
30.59 \\
24.31 \\
31.03 \\
25.60 \\
25.60\end{array}$ \\
\hline 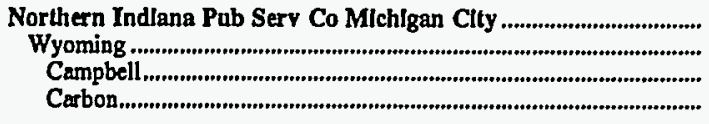 & $\begin{array}{r}1,444 \\
1,444 \\
770 \\
674\end{array}$ & $\begin{array}{r}9,782 \\
9,782 \\
8,719 \\
10,997\end{array}$ & $\begin{array}{l}.46 \\
.46 \\
.33 \\
.60\end{array}$ & $\begin{array}{l}.47 \\
.47 \\
.38 \\
.55\end{array}$ & $\begin{array}{l}5.84 \\
5.84 \\
5.33 \\
6.43\end{array}$ & $\begin{array}{l}146.5 \\
146.5 \\
102.6 \\
186.2\end{array}$ & $\begin{array}{l}28.66 \\
28.66 \\
17.89 \\
40.96\end{array}$ \\
\hline 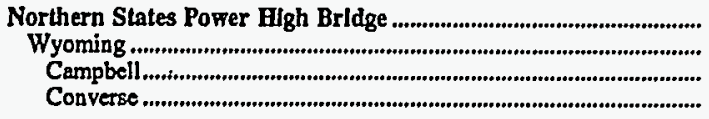 & $\begin{array}{r}580 \\
580 \\
526 \\
54\end{array}$ & $\begin{array}{l}8,753 \\
8,753 \\
8,750 \\
8,777\end{array}$ & $\begin{array}{l}.21 \\
.21 \\
.21 \\
.21\end{array}$ & $\begin{array}{l}.23 \\
.23 \\
.23 \\
.24\end{array}$ & $\begin{array}{l}4.64 \\
4.64 \\
4.64 \\
4.60\end{array}$ & $\begin{array}{l}114.9 \\
114.9 \\
114.8 \\
115.5\end{array}$ & $\begin{array}{l}20.12 \\
20.12 \\
20.10 \\
20.27\end{array}$ \\
\hline 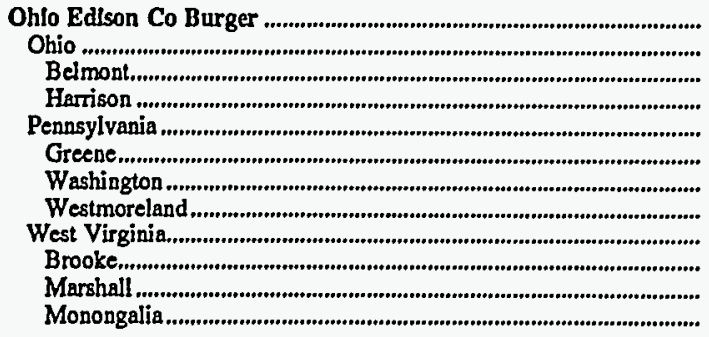 & $\begin{array}{r}564 \\
226 \\
106 \\
120 \\
180 \\
73 \\
64 \\
42 \\
158 \\
10 \\
73 \\
75\end{array}$ & $\begin{array}{l}12,470 \\
12,444 \\
12,580 \\
12,324 \\
12,635 \\
13,231 \\
11,951 \\
12,638 \\
12,320 \\
12,113 \\
12,426 \\
12,245\end{array}$ & $\begin{array}{l}2.98 \\
3.78 \\
4.22 \\
3.39 \\
2.41 \\
2.43 \\
2.83 \\
1.72 \\
2.49 \\
3.52 \\
3.31 \\
1.55\end{array}$ & $\begin{array}{l}2.39 \\
3.04 \\
3.35 \\
2.75 \\
1.90 \\
1.84 \\
2.37 \\
1.36 \\
2.02 \\
2.91 \\
2.66 \\
1.27\end{array}$ & $\begin{array}{r}10.57 \\
10.17 \\
9.35 \\
10.89 \\
10.26 \\
8.05 \\
11.93 \\
11.54 \\
11.49 \\
10.20 \\
10.13 \\
12.99\end{array}$ & $\begin{array}{r}93.1 \\
95.2 \\
82.6 \\
106.5 \\
93.0 \\
94.7 \\
87.4 \\
97.9 \\
90.5 \\
86.7 \\
79.0 \\
102.3\end{array}$ & $\begin{array}{l}23.23 \\
23.68 \\
20.79 \\
26.24 \\
23.49 \\
25.06 \\
20.88 \\
24.74 \\
22.29 \\
21.00 \\
19.63 \\
25.04\end{array}$ \\
\hline 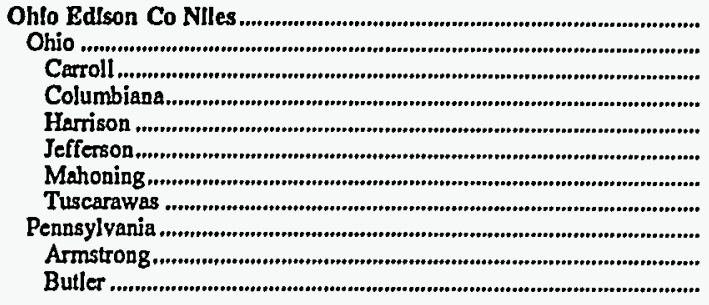 & $\begin{array}{r}473 \\
460 \\
133 \\
59 \\
147 \\
86 \\
10 \\
25 \\
13 \\
2 \\
11\end{array}$ & $\begin{array}{l}12,154 \\
12,145 \\
12,127 \\
12,100 \\
12,390 \\
11,964 \\
11,923 \\
11,628 \\
12,487 \\
12,579 \\
12,468\end{array}$ & $\begin{array}{l}2.92 \\
2.91 \\
2.64 \\
2.69 \\
3.40 \\
2.43 \\
3.02 \\
3.64 \\
3.00 \\
2.88 \\
3.02\end{array}$ & $\begin{array}{l}2.40 \\
2.40 \\
2.18 \\
2.22 \\
2.74 \\
2.04 \\
2.53 \\
3.13 \\
2.40 \\
2.29 \\
2.42\end{array}$ & $\begin{array}{r}10.98 \\
11.02 \\
10.84 \\
10.36 \\
10.44 \\
12.20 \\
11.58 \\
12.51 \\
9.76 \\
8.90 \\
9.93\end{array}$ & $\begin{array}{r}107.3 \\
107.2 \\
121.7 \\
112.1 \\
96.6 \\
106.0 \\
104.5 \\
86.5 \\
111.8 \\
110.5 \\
112.1\end{array}$ & $\begin{array}{l}26.08 \\
26.03 \\
29.51 \\
27.13 \\
23.93 \\
25.35 \\
24.92 \\
20.12 \\
27.92 \\
27.79 \\
27.95\end{array}$ \\
\hline 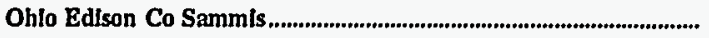 & 5,449 & 12,188 & .79 & .65 & 10.92 & 128.1 & 31.23 \\
\hline
\end{tabular}

Sec footnotes at end of table. 
Table B2. Profile of Coal Received at Table 1 Plants, 1995 (Continued)

\begin{tabular}{|c|c|c|c|c|c|c|c|}
\hline \multirow{2}{*}{$\begin{array}{c}\text { Electric Utility Plant } \\
\text { Origin State } \\
\text { County }\end{array}$} & \multirow{2}{*}{$\begin{array}{l}\text { Recelpts } \\
\text { (thousand } \\
\text { short tons) }\end{array}$} & \multicolumn{4}{|c|}{ Average Quality } & \multicolumn{2}{|c|}{$\begin{array}{l}\text { Average Dellvered } \\
\text { Cost }\end{array}$} \\
\hline & & $\begin{array}{c}\text { Btu } \\
\text { (per } \\
\text { pound) }\end{array}$ & $\begin{array}{c}\text { Sulfur } \\
\text { (percent } \\
\text { by } \\
\text { welght) }\end{array}$ & $\begin{array}{c}\text { Sulfur } \\
\text { (pounds } \\
\text { per } \\
\text { MM Btu) }\end{array}$ & $\begin{array}{c}\text { Ash } \\
\text { (percent } \\
\text { by } \\
\text { wetght) }\end{array}$ & $\begin{array}{l}\text { (cents } \\
\text { per } \\
\text { million } \\
\text { Btu) }\end{array}$ & $\begin{array}{l}\text { (dollars } \\
\text { per } \\
\text { short } \\
\text { ton) }\end{array}$ \\
\hline \multicolumn{8}{|l|}{ Ohlo Edison Co Sammis } \\
\hline 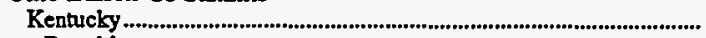 & 1,954 & 12,057 & 0.80 & 0.67 & 10.65 & 124.0 & 29.89 \\
\hline 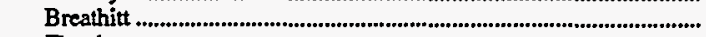 & 115 & 11,900 & .83 & .70 & 10.89 & 114.0 & 27.13 \\
\hline 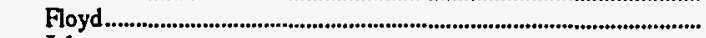 & 821 & 12,093 & .82 & .68 & 10.12 & 121.1 & 29.28 \\
\hline 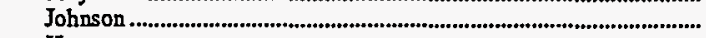 & 16 & 11,766 & .88 & .75 & 10.91 & 113.6 & 26.73 \\
\hline 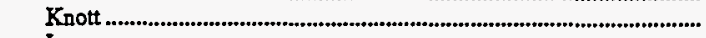 & 10 & 11,639 & .75 & .65 & 10.72 & 113.3 & 26.38 \\
\hline 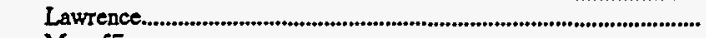 & 25 & 11,797 & .89 & .76 & 11.56 & 116.3 & 27.44 \\
\hline Magofin & 144 & 11,711 & .80 & .69 & 11.24 & 117.4 & 27.49 \\
\hline 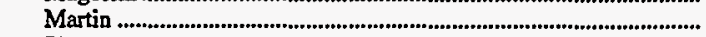 & 711 & 12,147 & .80 & .66 & 10.90 & 132.3 & 32.14 \\
\hline 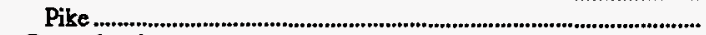 & 112 & 11,955 & .63 & .53 & 11.79 & 114.3 & 27.32 \\
\hline 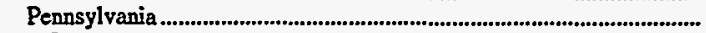 & 32 & 12,192 & .81 & .67 & 10.27 & 119.2 & 29.06 \\
\hline 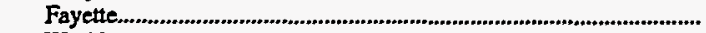 & 3 & 11,987 & .96 & .80 & 10.80 & 124.0 & 29.73 \\
\hline Washington & 9 & 11,949 & .87 & .73 & 9.16 & 113.8 & 27.20 \\
\hline 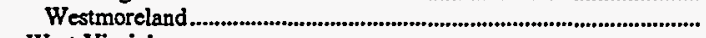 & 19 & 12,342 & .76 & .62 & 10.72 & 120.9 & 29.85 \\
\hline 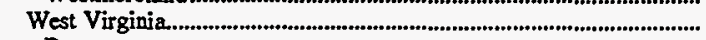 & 3,464 & 12,263 & .78 & .64 & 11.08 & 130.5 & 32.00 \\
\hline 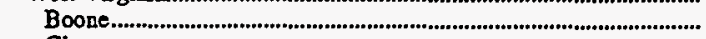 & 13 & 11,875 & .77 & .65 & 12.10 & 115.6 & 27.45 \\
\hline 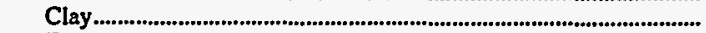 & 48 & 12,208 & .77 & .63 & 12.86 & 112.9 & 27.55 \\
\hline 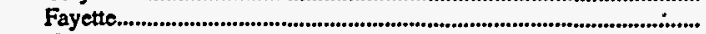 & 69 & 12,596 & .73 & .58 & 8.82 & 118.6 & 29.89 \\
\hline 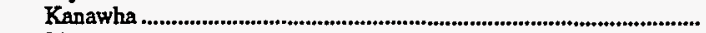 & 2,054 & 12,290 & .76 & .62 & 11.06 & 131.1 & 32.23 \\
\hline Lincoln & 12 & 11,542 & .81 & .70 & 11.30 & 127.2 & 29.36 \\
\hline Logan & 60 & 11,990 & .82 & .68 & 11.04 & 113.5 & 27.22 \\
\hline Mingo & 821 & 12,190 & .78 & .64 & 10.72 & 137.3 & 33.46 \\
\hline Webster & 387 & 12,301 & .86 & .70 & 12.09 & 120.4 & 29.61 \\
\hline 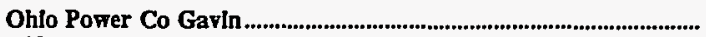 & 5,805 & 11,416 & 3.02 & 2.65 & 11.58 & 160.3 & 36.60 \\
\hline 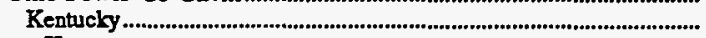 & 2 & 12,000 & .72 & .60 & 12.00 & 131.3 & 31.51 \\
\hline Knott & 1 & 12,000 & .72 & .60 & 12.00 & 131.3 & 31.51 \\
\hline Magoffin & 1 & 12,000 & .72 & .60 & 12.00 & 131.3 & 31.51 \\
\hline Perry & & 12,000 & .72 & .60 & 12.00 & 131.3 & 31.51 \\
\hline 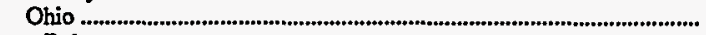 & 5,804 & 11,416 & 3.02 & 2.65 & 11.58 & 160.3 & 36.60 \\
\hline 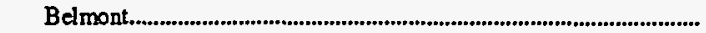 & 225 & 11,866 & 2.83 & 2.39 & 12.27 & 114.0 & 27.05 \\
\hline 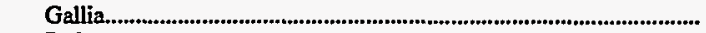 & 305 & 11,112 & 2.99 & 2.69 & 11.85 & 109.6 & 24.36 \\
\hline Jackson & 305 & 11,112 & 2.99 & 2.69 & 11.85 & 109.6 & 24.36 \\
\hline 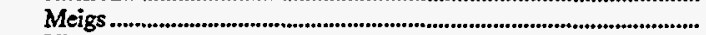 & 4,656 & 11,454 & 3.04 & 2.65 & 11.50 & 172.4 & 39.48 \\
\hline Vinton & 313 & 11,112 & 2.99 & 2.69 & 11.85 & 109.6 & 24.36 \\
\hline Ohlo Porrer Co Kammer & 1,952 & 12,307 & 3.44 & 2.79 & 10.76 & 86.3 & 21.23 \\
\hline 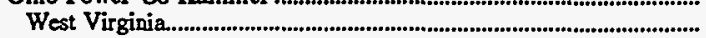 & 1,952 & 12,307 & 3.44 & 2.79 & 10.76 & 86.3 & 21.23 \\
\hline 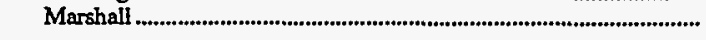 & 1,952 & 12,307 & 3.44 & 2.79 & 10.76 & 86.3 & 21.23 \\
\hline Ohlo Power Co Mitchell & 3,257 & 12,310 & .96 & .78 & 1288 & 141.9 & 34.95 \\
\hline 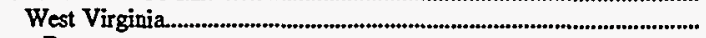 & 3,257 & 12,310 & .96 & .78 & 12.88 & 141.9 & 34.95 \\
\hline 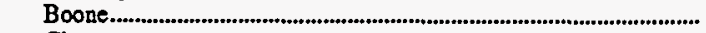 & 1,445 & 12,431 & .75 & .60 & 11.73 & 147.9 & 36.76 \\
\hline 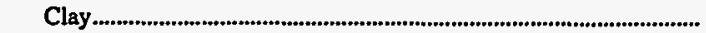 & 488 & 12,195 & .74 & .61 & 13.41 & 142.3 & 34.72 \\
\hline 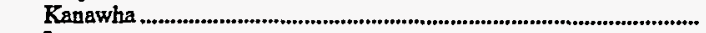 & 54 & 12,643 & .72 & .57 & 11.09 & 112.5 & 28.45 \\
\hline Logan & 154 & 12,328 & .66 & .54 & 12.74 & 117.9 & 29.06 \\
\hline 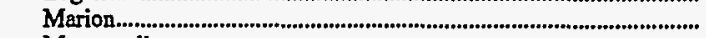 & 855 & 12,120 & 1.51 & 1.24 & 14.75 & 148.2 & 35.93 \\
\hline 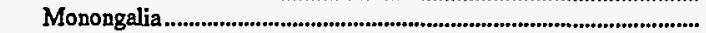 & 38 & 12,227 & 1.33 & 1.08 & 13.31 & 101.8 & 24.89 \\
\hline Webster & 223 & 12,426 & .85 & .68 & 12.42 & 109.9 & 27.30 \\
\hline 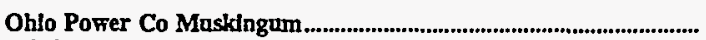 & 2,229 & 12,010 & 256 & 2.13 & 11.54 & 182.3 & 43.80 \\
\hline Ohio & 1,064 & 11,722 & 4.57 & 3.90 & 11.59 & 239.3 & 56.10 \\
\hline 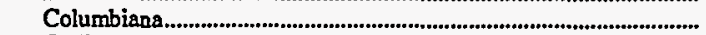 & 12 & 12,336 & 1.11 & .90 & 8.38 & 173.2 & 42.72 \\
\hline 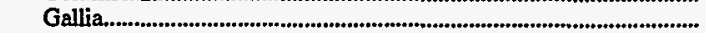 & 3 & 10,920 & .87 & .80 & 8.75 & 186.0 & 40.63 \\
\hline 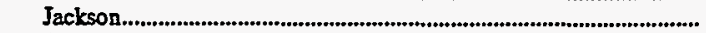 & 3 & 10,920 & .87 & .80 & 8.75 & 186.0 & 40.63 \\
\hline 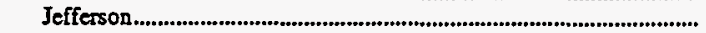 & $\overline{7}$ & 12,274 & .68 & .55 & 10.46 & 180.0 & 44.19 \\
\hline 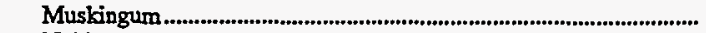 & 106 & 11,678 & 4.63 & 3.97 & 11.75 & 245.7 & 57.38 \\
\hline 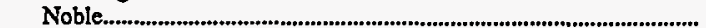 & 858 & 11,678 & 5.01 & 4.29 & 11.75 & 245.7 & 57.38 \\
\hline Vinton & 3 & 10,919 & .87 & .80 & 8.75 & 186.0 & 40.62 \\
\hline Unknown 1 & $\overrightarrow{1}$ & 12,463 & 1.11 & .89 & 8.40 & 179.5 & 44.74 \\
\hline 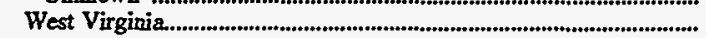 & 1,165 & 12,273 & .72 & .58 & 11.49 & 132.7 & 32.58 \\
\hline 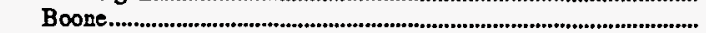 & 95 & 12,040 & .78 & .65 & 12.77 & 122.1 & 29.40 \\
\hline Logan & 998 & 12,281 & .70 & .57 & 11.37 & 134.3 & 32.98 \\
\hline Webster & 72 & 12,473 & .88 & .70 & 11.49 & 124.9 & 31.17 \\
\hline 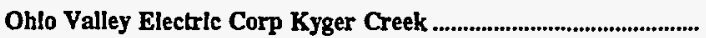 & 2,663 & 13,092 & 1.56 & 1.19 & 6.65 & 122.9 & 3218 \\
\hline
\end{tabular}

See footnotes at end of table. 
Table B2. Profile of Coal Received at Table 1 Plants, 1995 (Continued)

\begin{tabular}{|c|c|c|c|c|c|c|c|}
\hline \multirow{2}{*}{$\begin{array}{c}\text { Electric UtIllty Plant } \\
\text { Orlgin State } \\
\text { County }\end{array}$} & \multirow{2}{*}{$\begin{array}{l}\text { Recelpts } \\
\text { (thousand } \\
\text { short tons) }\end{array}$} & \multicolumn{4}{|c|}{ Average Quality } & \multicolumn{2}{|c|}{$\begin{array}{l}\text { Average Dellvered } \\
\text { Cost }\end{array}$} \\
\hline & & $\begin{array}{l}\text { Btu } \\
\text { (per } \\
\text { pound) }\end{array}$ & $\begin{array}{l}\text { Sulfur } \\
\text { (percent } \\
\text { by } \\
\text { weight) }\end{array}$ & $\begin{array}{c}\text { Sulfur } \\
\text { (pounds } \\
\text { per } \\
\text { MM Btu) }\end{array}$ & $\begin{array}{c}\text { Ash } \\
\text { (percent } \\
\text { by } \\
\text { welght) }\end{array}$ & $\begin{array}{l}\text { (cents } \\
\text { per } \\
\text { million } \\
\text { Btu) }\end{array}$ & $\begin{array}{l}\text { (dollars } \\
\text { per } \\
\text { short } \\
\text { ton) }\end{array}$ \\
\hline 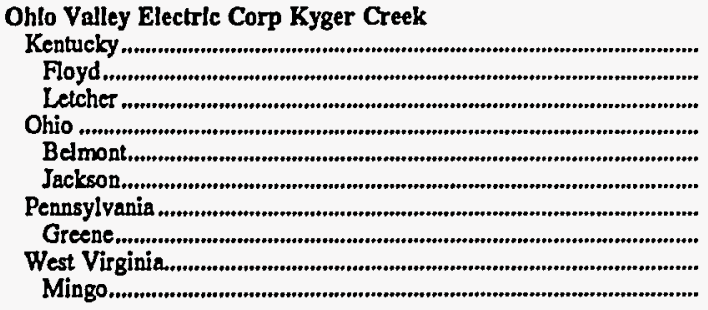 & $\begin{array}{r}1,224 \\
238 \\
986 \\
132 \\
22 \\
110 \\
977 \\
977 \\
330 \\
330\end{array}$ & $\begin{array}{l}13,333 \\
13,203 \\
13,364 \\
11,294 \\
12,171 \\
11,118 \\
13,047 \\
13,047 \\
13,049 \\
13,049\end{array}$ & $\begin{array}{l}1.39 \\
1.39 \\
1.39 \\
3.71 \\
3.93 \\
3.67 \\
1.49 \\
1.49 \\
1.54 \\
1.54\end{array}$ & $\begin{array}{l}1.04 \\
1.05 \\
1.04 \\
3.29 \\
3.23 \\
3.30 \\
1.14 \\
1.14 \\
1.18 \\
1.18\end{array}$ & $\begin{array}{r}5.69 \\
6.36 \\
5.53 \\
11.94 \\
12.15 \\
11.89 \\
6.96 \\
6.96 \\
7.18 \\
7.18\end{array}$ & $\begin{array}{r}125.7 \\
124.9 \\
125.9 \\
86.8 \\
83.1 \\
87.6 \\
122.2 \\
122.2 \\
127.0 \\
127.0\end{array}$ & $\begin{array}{l}33.51 \\
32.97 \\
33.65 \\
19.60 \\
20.24 \\
19.47 \\
31.88 \\
31.88 \\
33.15 \\
33.15\end{array}$ \\
\hline 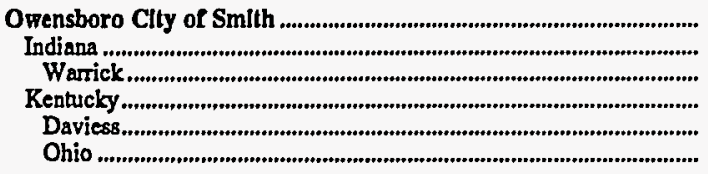 & $\begin{array}{r}1,065 \\
278 \\
278 \\
787 \\
551 \\
236\end{array}$ & $\begin{array}{l}11,202 \\
11,352 \\
11,352 \\
11,149 \\
11,177 \\
11,082\end{array}$ & $\begin{array}{l}2.97 \\
3.00 \\
3.00 \\
2.95 \\
2.81 \\
3.28\end{array}$ & $\begin{array}{l}2.65 \\
2.64 \\
2.64 \\
2.65 \\
2.52 \\
2.96\end{array}$ & $\begin{array}{r}8.71 \\
7.96 \\
7.96 \\
8.98 \\
8.38 \\
10.38\end{array}$ & $\begin{array}{l}95.1 \\
97.0 \\
97.0 \\
94.4 \\
96.0 \\
90.7\end{array}$ & $\begin{array}{l}21.30 \\
22.02 \\
22.02 \\
21.05 \\
21.46 \\
20.10\end{array}$ \\
\hline $\begin{array}{l}\text { Pennsylvanla Electric Co Conemaugh } \\
\text { Pennsylvania } \\
\text { Armstrong } \\
\text { Cambria. } \\
\text { Centre. } \\
\text { Clearfield } \\
\text { Fayette } \\
\text { Indiana } \\
\text { Somerset } \\
\text { Westmoreland }\end{array}$ & $\begin{array}{r}4,123 \\
4,123 \\
508 \\
144 \\
18 \\
42 \\
247 \\
375 \\
2,589 \\
200\end{array}$ & $\begin{array}{l}12,502 \\
12,502 \\
12,579 \\
12,770 \\
12,355 \\
12,480 \\
12,523 \\
12,400 \\
12,497 \\
12,361\end{array}$ & $\begin{array}{l}2.25 \\
2.25 \\
2.36 \\
2.18 \\
2.44 \\
2.31 \\
2.37 \\
2.14 \\
2.23 \\
2.37\end{array}$ & $\begin{array}{l}1.80 \\
1.80 \\
1.88 \\
1.70 \\
1.98 \\
1.85 \\
1.90 \\
1.72 \\
1.78 \\
1.92\end{array}$ & $\begin{array}{l}13.40 \\
13.40 \\
11.63 \\
11.15 \\
15.10 \\
14.41 \\
13.24 \\
13.70 \\
13.82 \\
13.23\end{array}$ & $\begin{array}{l}114.1 \\
114.1 \\
108.4 \\
112.8 \\
116.3 \\
106.2 \\
103.1 \\
110.7 \\
117.4 \\
107.9\end{array}$ & $\begin{array}{l}28.53 \\
28.53 \\
27.27 \\
28.81 \\
28.72 \\
26.51 \\
25.81 \\
27.46 \\
29.35 \\
26.68\end{array}$ \\
\hline 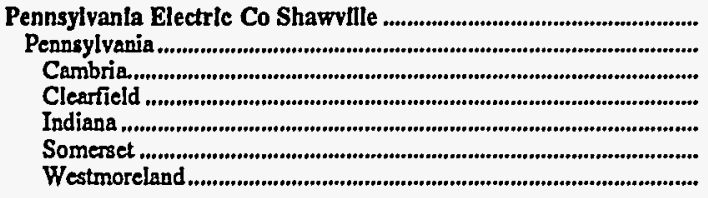 & $\begin{array}{r}1,530 \\
1,530 \\
84 \\
1,401 \\
14 \\
16 \\
15\end{array}$ & $\begin{array}{l}12,279 \\
12,279 \\
12,238 \\
12,285 \\
12,162 \\
12,201 \\
12,129\end{array}$ & $\begin{array}{l}1.82 \\
1.82 \\
1.65 \\
1.83 \\
1.84 \\
1.68 \\
2.09\end{array}$ & $\begin{array}{l}1.48 \\
1.48 \\
1.35 \\
1.49 \\
1.51 \\
1.38 \\
1.72\end{array}$ & $\begin{array}{l}13.30 \\
13.30 \\
12.18 \\
13.37 \\
14.36 \\
11.99 \\
13.93\end{array}$ & $\begin{array}{l}113.3 \\
113.3 \\
117.1 \\
113.2 \\
112.8 \\
110.6 \\
109.2\end{array}$ & $\begin{array}{l}27.82 \\
27.82 \\
28.67 \\
27.80 \\
27.44 \\
26.98 \\
26.48\end{array}$ \\
\hline 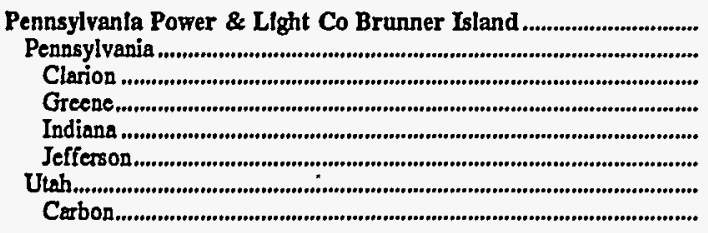 & $\begin{array}{r}2,756 \\
2,747 \\
90 \\
2,257 \\
351 \\
49 \\
9 \\
9\end{array}$ & $\begin{array}{l}13,067 \\
13,070 \\
12,704 \\
13,127 \\
12,786 \\
13,166 \\
12,239 \\
12,239\end{array}$ & $\begin{array}{r}1.61 \\
1.61 \\
1.60 \\
1.56 \\
2.00 \\
1.16 \\
.50 \\
.50\end{array}$ & $\begin{array}{r}1.23 \\
1.23 \\
1.26 \\
1.19 \\
1.56 \\
.88 \\
.41 \\
.41\end{array}$ & $\begin{array}{r}8.06 \\
8.05 \\
8.97 \\
7.43 \\
11.57 \\
9.83 \\
10.10 \\
10.10\end{array}$ & $\begin{array}{l}150.2 \\
150.1 \\
139.7 \\
151.5 \\
145.3 \\
135.7 \\
184.9 \\
184.9\end{array}$ & $\begin{array}{l}39.25 \\
39.23 \\
35.49 \\
39.78 \\
37.17 \\
35.74 \\
45.26 \\
45.26\end{array}$ \\
\hline 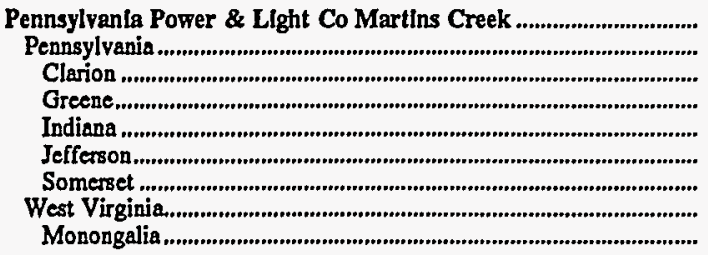 & $\begin{array}{r}288 \\
269 \\
21 \\
147 \\
10 \\
81 \\
10 \\
19 \\
19\end{array}$ & $\begin{array}{l}13,055 \\
13,030 \\
12,776 \\
13,106 \\
12,817 \\
13,044 \\
12,557 \\
13,412 \\
13,412\end{array}$ & $\begin{array}{l}1.59 \\
1.55 \\
1.65 \\
1.58 \\
2.30 \\
1.31 \\
2.04 \\
2.13 \\
2.13\end{array}$ & $\begin{array}{l}1.21 \\
1.19 \\
1.29 \\
1.21 \\
1.79 \\
1.00 \\
1.62 \\
1.59 \\
1.59\end{array}$ & $\begin{array}{r}8.71 \\
8.83 \\
8.83 \\
7.72 \\
11.90 \\
9.77 \\
14.50 \\
7.00 \\
7.00\end{array}$ & $\begin{array}{l}146.9 \\
148.5 \\
143.3 \\
155.2 \\
137.6 \\
139.8 \\
142.1 \\
124.8 \\
124.8\end{array}$ & $\begin{array}{l}\mathbf{3 8 . 3 7} \\
38.71 \\
36.61 \\
40.68 \\
35.27 \\
36.48 \\
35.69 \\
33.48 \\
33.48\end{array}$ \\
\hline 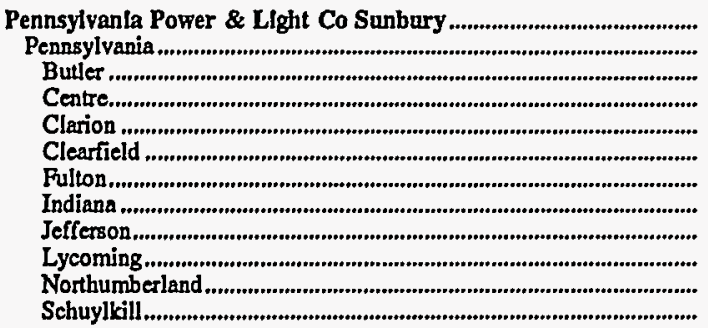 & $\begin{array}{r}1,205 \\
1,205 \\
2 \\
31 \\
26 \\
363 \\
3 \\
2 \\
25 \\
12 \\
79 \\
384\end{array}$ & $\begin{array}{r}9,729 \\
9,729 \\
9,305 \\
12,321 \\
12,676 \\
12,263 \\
12,306 \\
12,522 \\
12,784 \\
12,303 \\
7,738 \\
7,253\end{array}$ & $\begin{array}{r}1.02 \\
1.02 \\
1.16 \\
1.17 \\
1.60 \\
1.55 \\
1.54 \\
1.82 \\
1.61 \\
.89 \\
.74 \\
.50\end{array}$ & $\begin{array}{r}1.05 \\
1.05 \\
1.25 \\
.95 \\
1.26 \\
1.27 \\
1.25 \\
1.45 \\
1.26 \\
.72 \\
.95 \\
.69\end{array}$ & $\begin{array}{r}26.15 \\
26.15 \\
27.90 \\
15.08 \\
9.47 \\
14.76 \\
14.27 \\
13.50 \\
11.08 \\
16.57 \\
33.48 \\
38.01\end{array}$ & $\begin{array}{r}124.9 \\
124.9 \\
96.7 \\
130.8 \\
135.7 \\
142.8 \\
136.4 \\
139.0 \\
136.1 \\
134.8 \\
71.2 \\
95.6\end{array}$ & $\begin{array}{l}24.31 \\
24.31 \\
18.00 \\
32.24 \\
34.41 \\
35.03 \\
33.58 \\
34.81 \\
34.80 \\
33.17 \\
11.02 \\
13.86\end{array}$ \\
\hline
\end{tabular}

See footnotes at end of table. 
Table B2. Profile of Coal Received at Table 1 Plants, 1995 (Continued)

\begin{tabular}{|c|c|c|c|c|c|c|c|}
\hline \multirow{2}{*}{$\begin{array}{l}\text { Electric Utility Piant } \\
\text { Origin State } \\
\text { County }\end{array}$} & \multirow{2}{*}{$\begin{array}{l}\text { Recelpts } \\
\text { (thousand } \\
\text { short tons) }\end{array}$} & \multicolumn{4}{|c|}{ Average Quality } & \multicolumn{2}{|c|}{$\begin{array}{l}\text { Average Dellvered } \\
\text { Cost }\end{array}$} \\
\hline & & $\begin{array}{l}\text { Btar } \\
\text { (per } \\
\text { pound) }\end{array}$ & $\begin{array}{l}\text { Sulfur } \\
\text { (percent } \\
\text { by } \\
\text { weight) }\end{array}$ & $\begin{array}{l}\text { Sulfur } \\
\text { (pounds } \\
\text { per } \\
\text { MM Btu) }\end{array}$ & $\begin{array}{l}\text { Ash } \\
\text { (percent } \\
\text { by } \\
\text { weIght) }\end{array}$ & $\begin{array}{l}\text { (cents } \\
\text { per } \\
\text { millilon } \\
\text { Btu) }\end{array}$ & $\begin{array}{l}\text { (dollars } \\
\text { per } \\
\text { short } \\
\text { ton) }\end{array}$ \\
\hline $\begin{array}{l}\text { Pennsylvanla Power \& Llght Co Sunbury } \\
\text { Pennsylvania } \\
\text { Somerset } \\
\text { Unknown } 1 \text {. }\end{array}$ & $\begin{array}{r}19 \\
259\end{array}$ & $\begin{array}{r}12,641 \\
9,172\end{array}$ & $\begin{array}{r}1.77 \\
.93\end{array}$ & $\begin{array}{l}1.40 \\
1.02\end{array}$ & $\begin{array}{l}13.92 \\
28.32\end{array}$ & $\begin{array}{l}137.6 \\
133.8\end{array}$ & $\begin{array}{l}34.79 \\
24.54\end{array}$ \\
\hline 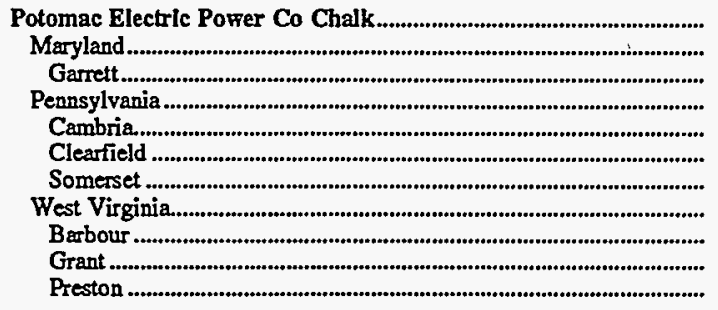 & $\begin{array}{r}1,353 \\
244 \\
244 \\
872 \\
186 \\
344 \\
342 \\
237 \\
28 \\
150 \\
59\end{array}$ & $\begin{array}{l}13,206 \\
13,210 \\
13,210 \\
13,190 \\
12,860 \\
13,285 \\
13,273 \\
13,261 \\
14,210 \\
13,139 \\
13,122\end{array}$ & $\begin{array}{r}1.36 \\
1.46 \\
1.46 \\
1.34 \\
1.35 \\
1.51 \\
1.17 \\
1.34 \\
.98 \\
1.38 \\
1.41\end{array}$ & $\begin{array}{r}1.03 \\
1.11 \\
1.11 \\
1.02 \\
1.05 \\
1.14 \\
.88 \\
1.01 \\
.69 \\
1.05 \\
1.07\end{array}$ & $\begin{array}{l}9.20 \\
9.60 \\
9.60 \\
9.24 \\
9.18 \\
8.94 \\
9.56 \\
8.67 \\
6.65 \\
9.21 \\
8.27\end{array}$ & $\begin{array}{l}153.7 \\
162.3 \\
162.3 \\
149.5 \\
147.6 \\
149.4 \\
150.8 \\
160.2 \\
151.8 \\
158.0 \\
170.0\end{array}$ & $\begin{array}{l}40.60 \\
42.88 \\
42.88 \\
39.45 \\
37.95 \\
39.69 \\
40.02 \\
42.48 \\
43.15 \\
41.51 \\
44.62\end{array}$ \\
\hline 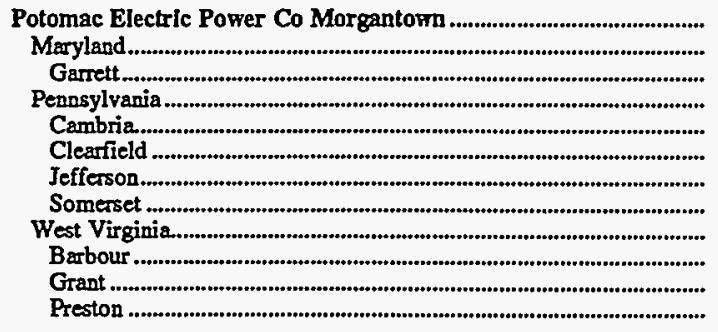 & $\begin{array}{r}2,250 \\
776 \\
776 \\
694 \\
154 \\
235 \\
16 \\
289 \\
780 \\
105 \\
477 \\
198\end{array}$ & $\begin{array}{l}13,169 \\
13,247 \\
13,247 \\
13,084 \\
13,022 \\
12,893 \\
12,925 \\
13,282 \\
13,166 \\
13,242 \\
13,134 \\
13,205\end{array}$ & $\begin{array}{l}1.39 \\
1.49 \\
1.49 \\
1.34 \\
1.33 \\
1.52 \\
1.49 \\
1.19 \\
1.35 \\
1.16 \\
1.35 \\
1.45\end{array}$ & $\begin{array}{r}1.06 \\
1.12 \\
1.12 \\
1.02 \\
1.02 \\
1.18 \\
1.16 \\
.90 \\
1.02 \\
.88 \\
1.03 \\
1.10\end{array}$ & $\begin{array}{r}9.35 \\
9.57 \\
9.57 \\
9.77 \\
9.21 \\
10.39 \\
9.75 \\
9.55 \\
8.75 \\
7.59 \\
9.25 \\
8.17\end{array}$ & $\begin{array}{l}158.7 \\
161.5 \\
161.5 \\
152.6 \\
147.8 \\
157.2 \\
147.9 \\
151.7 \\
161.2 \\
163.2 \\
157.8 \\
168.3\end{array}$ & $\begin{array}{l}41.79 \\
42.78 \\
42.78 \\
39.93 \\
38.50 \\
40.54 \\
38.22 \\
40.30 \\
42.45 \\
43.22 \\
41.44 \\
44.46\end{array}$ \\
\hline 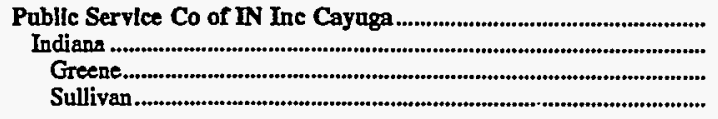 & $\begin{array}{r}2,514 \\
2,514 \\
10 \\
2,504\end{array}$ & $\begin{array}{l}10,978 \\
10,978 \\
11,153 \\
10,978\end{array}$ & $\begin{array}{l}1.56 \\
1.56 \\
1.33 \\
1.56\end{array}$ & $\begin{array}{l}1.42 \\
1.42 \\
1.19 \\
1.42\end{array}$ & $\begin{array}{l}9.56 \\
9.56 \\
8.80 \\
9.57\end{array}$ & $\begin{array}{l}129.0 \\
129.0 \\
127.6 \\
129.0\end{array}$ & $\begin{array}{l}28.32 \\
28.32 \\
28.46 \\
28.32\end{array}$ \\
\hline 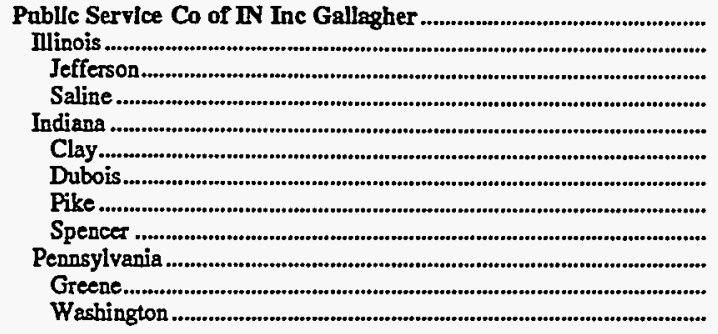 & $\begin{array}{r}1,126 \\
445 \\
120 \\
325 \\
133 \\
6 \\
114 \\
2 \\
11 \\
547 \\
538 \\
9\end{array}$ & $\begin{array}{l}12,405 \\
11,913 \\
11,698 \\
11,993 \\
11,064 \\
11,210 \\
11,100 \\
12,132 \\
10,431 \\
13,131 \\
13,128 \\
13,299\end{array}$ & $\begin{array}{l}1.86 \\
1.43 \\
1.62 \\
1.36 \\
1.31 \\
1.05 \\
1.24 \\
2.40 \\
2.00 \\
2.35 \\
2.37 \\
1.21\end{array}$ & $\begin{array}{r}1.50 \\
1.20 \\
1.38 \\
1.14 \\
1.18 \\
.94 \\
1.12 \\
1.98 \\
1.92 \\
1.79 \\
1.80 \\
.91\end{array}$ & $\begin{array}{r}7.80 \\
7.05 \\
7.42 \\
6.91 \\
9.65 \\
7.80 \\
9.69 \\
8.00 \\
10.50 \\
7.97 \\
8.01 \\
5.60\end{array}$ & $\begin{array}{r}111.9 \\
123.4 \\
119.6 \\
124.8 \\
116.2 \\
114.6 \\
119.0 \\
101.5 \\
88.6 \\
102.4 \\
102.6 \\
89.3\end{array}$ & $\begin{array}{l}27.75 \\
29.41 \\
27.99 \\
29.93 \\
25.72 \\
25.69 \\
26.42 \\
24.63 \\
18.48 \\
26.90 \\
26.95 \\
23.75\end{array}$ \\
\hline 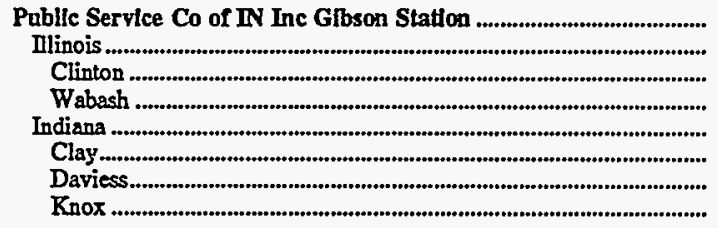 & $\begin{array}{r}7,517 \\
7,108 \\
3,002 \\
4,106 \\
409 \\
26 \\
111 \\
271\end{array}$ & $\begin{array}{l}10,951 \\
10,937 \\
10,868 \\
10,988 \\
11,198 \\
10,977 \\
11,873 \\
10,943\end{array}$ & $\begin{array}{r}2.22 \\
2.26 \\
3.30 \\
1.50 \\
1.53 \\
.78 \\
.63 \\
1.97\end{array}$ & $\begin{array}{r}2.03 \\
2.07 \\
3.03 \\
1.37 \\
1.37 \\
.71 \\
.53 \\
1.80\end{array}$ & $\begin{array}{r}9.42 \\
9.47 \\
7.92 \\
10.61 \\
8.58 \\
8.81 \\
5.51 \\
9.82\end{array}$ & $\begin{array}{l}143.9 \\
145.0 \\
142.9 \\
146.6 \\
125.1 \\
124.8 \\
124.1 \\
125.5\end{array}$ & $\begin{array}{l}31.52 \\
31.72 \\
31.07 \\
32.21 \\
28.01 \\
27.40 \\
29.46 \\
27.47\end{array}$ \\
\hline 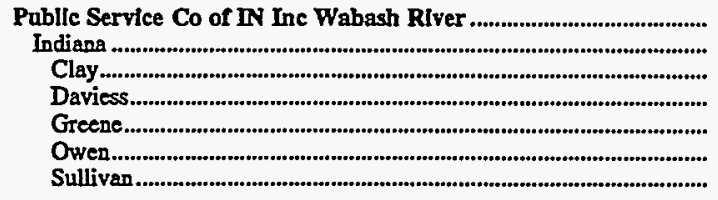 & $\begin{array}{r}1,156 \\
1,156 \\
50 \\
16 \\
794 \\
58 \\
239\end{array}$ & $\begin{array}{l}11,126 \\
11,126 \\
11,075 \\
11,335 \\
11,240 \\
11,106 \\
10,747\end{array}$ & $\begin{array}{l}1.58 \\
1.58 \\
1.28 \\
1.55 \\
1.64 \\
1.38 \\
1.48\end{array}$ & $\begin{array}{l}1.42 \\
1.42 \\
1.16 \\
1.37 \\
1.46 \\
1.25 \\
1.38\end{array}$ & $\begin{array}{l}8.50 \\
8.50 \\
8.83 \\
7.50 \\
8.05 \\
8.63 \\
9.95\end{array}$ & $\begin{array}{l}118.8 \\
118.8 \\
123.8 \\
119.1 \\
121.3 \\
124.9 \\
107.2\end{array}$ & $\begin{array}{l}26.43 \\
26.43 \\
27.43 \\
27.00 \\
27.27 \\
27.74 \\
23.05\end{array}$ \\
\hline 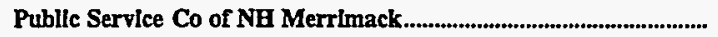 & 1,013 & 13,234 & 1.64 & 1.24 & 6.73 & 157.9 & 41.80 \\
\hline
\end{tabular}

See footnotes at end of table. 
Table B2. Profile of Coal Received at Table 1 Plants, 1995 (Continued)

\begin{tabular}{|c|c|c|c|c|c|c|c|}
\hline \multirow{2}{*}{$\begin{array}{c}\text { Electric Utllity Plant } \\
\text { Orlgin State } \\
\text { County }\end{array}$} & \multirow{2}{*}{$\begin{array}{l}\text { Recelpts } \\
\text { (thousand } \\
\text { short tons) }\end{array}$} & \multicolumn{4}{|c|}{ Average Quallty } & \multicolumn{2}{|c|}{$\begin{array}{c}\text { Average Dellvered } \\
\text { Cost }\end{array}$} \\
\hline & & $\begin{array}{c}\text { Btu } \\
\text { (per } \\
\text { pound) }\end{array}$ & $\begin{array}{c}\text { Sulfur } \\
\text { (percent } \\
\text { by } \\
\text { welght) }\end{array}$ & $\begin{array}{c}\text { Sulfur } \\
\text { (pounds } \\
\text { per } \\
\text { MM Btu) }\end{array}$ & $\begin{array}{c}\text { Ash } \\
\text { (percent } \\
\text { by } \\
\text { welght) }\end{array}$ & $\begin{array}{l}\text { (cents } \\
\text { per } \\
\text { millilon } \\
\text { Btu) }\end{array}$ & $\begin{array}{l}\text { (dollars } \\
\text { per } \\
\text { short } \\
\text { ton) }\end{array}$ \\
\hline 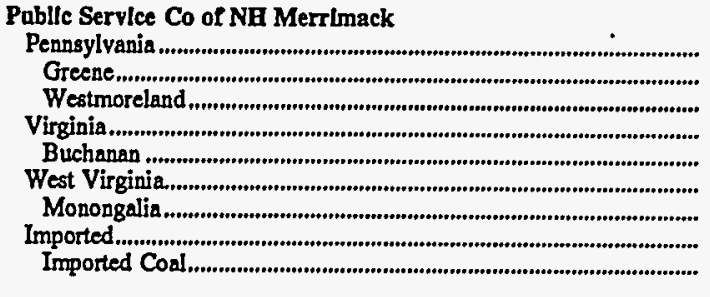 & $\begin{array}{r}759 \\
750 \\
9 \\
19 \\
19 \\
223 \\
223 \\
12 \\
12\end{array}$ & $\begin{array}{l}13,203 \\
13,202 \\
13,345 \\
13,910 \\
13,910 \\
13,366 \\
13,366 \\
11,578 \\
11,578\end{array}$ & $\begin{array}{r}1.49 \\
1.49 \\
1.44 \\
.68 \\
.68 \\
2.29 \\
2.29 \\
.53 \\
.53\end{array}$ & $\begin{array}{r}1.12 \\
1.13 \\
1.08 \\
.49 \\
.49 \\
1.72 \\
1.72 \\
.46 \\
.46\end{array}$ & $\begin{array}{l}6.90 \\
6.91 \\
6.20 \\
7.00 \\
7.00 \\
6.28 \\
6.28 \\
3.80 \\
3.80\end{array}$ & $\begin{array}{l}161.1 \\
161.1 \\
159.8 \\
203.5 \\
203.5 \\
141.7 \\
141.7 \\
192.9 \\
192.9\end{array}$ & $\begin{array}{l}42.53 \\
42.53 \\
42.65 \\
56.61 \\
56.61 \\
37.89 \\
37.89 \\
44.67 \\
44.67\end{array}$ \\
\hline 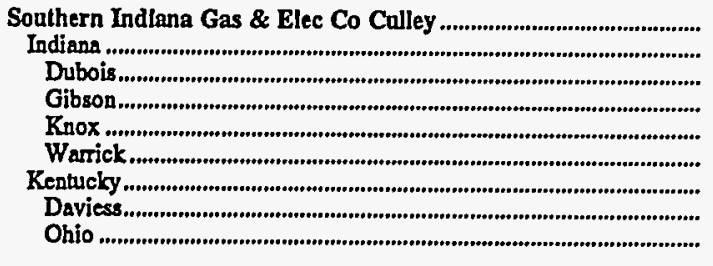 & $\begin{array}{r}1,007 \\
1,000 \\
106 \\
130 \\
10 \\
753 \\
8 \\
2 \\
6\end{array}$ & $\begin{array}{l}11,265 \\
11,262 \\
11,022 \\
11,390 \\
10,979 \\
11,278 \\
11,581 \\
11,024 \\
11,719\end{array}$ & $\begin{array}{l}3.10 \\
3.11 \\
1.83 \\
3.22 \\
1.33 \\
3.30 \\
1.76 \\
3.50 \\
1.33\end{array}$ & $\begin{array}{l}2.75 \\
2.76 \\
1.66 \\
2.83 \\
1.21 \\
2.92 \\
1.52 \\
3.17 \\
1.13\end{array}$ & $\begin{array}{r}9.50 \\
9.53 \\
10.21 \\
9.27 \\
8.90 \\
9.48 \\
6.21 \\
10.20 \\
5.22\end{array}$ & $\begin{array}{l}114.3 \\
114.1 \\
132.4 \\
120.2 \\
146.5 \\
110.1 \\
141.6 \\
119.8 \\
146.7\end{array}$ & $\begin{array}{l}25.76 \\
25.71 \\
29.19 \\
27.38 \\
32.17 \\
24.84 \\
32.81 \\
26.41 \\
34.38\end{array}$ \\
\hline 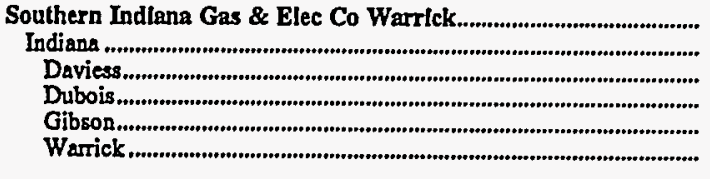 & $\begin{array}{r}439 \\
439 \\
14 \\
9 \\
265 \\
150\end{array}$ & $\begin{array}{l}11,276 \\
11,276 \\
11,451 \\
11,193 \\
11,441 \\
10,972\end{array}$ & $\begin{array}{l}2.82 \\
2.82 \\
2.24 \\
2.73 \\
2.78 \\
2.97\end{array}$ & $\begin{array}{l}2.50 \\
2.50 \\
1.96 \\
2.44 \\
2.43 \\
2.71\end{array}$ & $\begin{array}{l}8.46 \\
8.46 \\
9.10 \\
9.70 \\
8.07 \\
9.02\end{array}$ & $\begin{array}{r}104.3 \\
104.3 \\
102.0 \\
96.7 \\
103.3 \\
106.8\end{array}$ & $\begin{array}{l}23.52 \\
23.52 \\
23.36 \\
21.65 \\
23.64 \\
23.44\end{array}$ \\
\hline 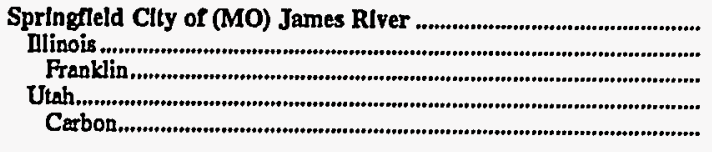 & $\begin{array}{r}351 \\
18 \\
18 \\
333 \\
333\end{array}$ & $\begin{array}{l}11,786 \\
11,658 \\
11,658 \\
11,793 \\
11,793\end{array}$ & $\begin{array}{r}.54 \\
2.56 \\
2.56 \\
.43 \\
.43\end{array}$ & $\begin{array}{r}.46 \\
2.20 \\
2.20 \\
.37 \\
.37\end{array}$ & $\begin{array}{l}8.31 \\
8.53 \\
8.53 \\
8.30 \\
8.30\end{array}$ & $\begin{array}{l}150.3 \\
138.6 \\
138.6 \\
150.9 \\
150.9\end{array}$ & $\begin{array}{l}35.42 \\
32.33 \\
32.33 \\
35.58 \\
35.58\end{array}$ \\
\hline 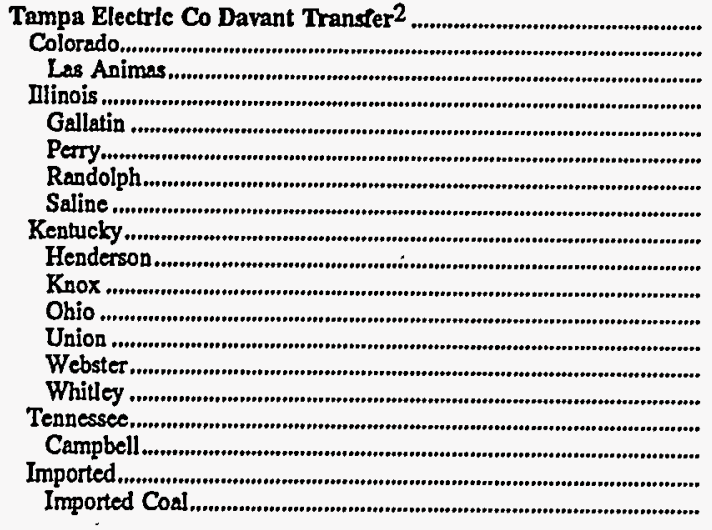 & $\begin{array}{r}5,388 \\
811 \\
811 \\
2,371 \\
28 \\
1,132 \\
119 \\
1,092 \\
1,737 \\
388 \\
2 \\
335 \\
783 \\
146 \\
84 \\
120 \\
120 \\
349 \\
349\end{array}$ & $\begin{array}{r}11,713 \\
12,745 \\
12,745 \\
11,536 \\
12,703 \\
11,002 \\
10,995 \\
12,120 \\
11,818 \\
11,249 \\
12,541 \\
11,407 \\
12,028 \\
12,704 \\
12,572 \\
12,565 \\
12,565 \\
9,696 \\
9,696\end{array}$ & $\begin{array}{r}1.95 \\
.43 \\
.43 \\
2.26 \\
2.71 \\
3.03 \\
3.06 \\
1.36 \\
2.62 \\
2.48 \\
.90 \\
2.69 \\
2.79 \\
2.82 \\
1.09 \\
1.12 \\
1.12 \\
.31 \\
.31\end{array}$ & $\begin{array}{r}1.66 \\
.34 \\
.34 \\
1.96 \\
2.13 \\
2.75 \\
2.78 \\
1.12 \\
2.22 \\
2.21 \\
.72 \\
2.36 \\
2.32 \\
2.22 \\
.87 \\
.89 \\
.89 \\
.32 \\
.32\end{array}$ & $\begin{array}{r}7.76 \\
9.84 \\
9.84 \\
8.27 \\
8.85 \\
9.44 \\
9.56 \\
6.89 \\
7.35 \\
8.26 \\
10.50 \\
8.89 \\
6.18 \\
7.44 \\
7.73 \\
8.66 \\
8.66 \\
1.16 \\
1.16\end{array}$ & $\begin{array}{l}162.5 \\
184.3 \\
184.3 \\
170.5 \\
142.9 \\
195.1 \\
135.9 \\
151.4 \\
139.0 \\
130.0 \\
166.6 \\
122.0 \\
135.7 \\
160.9 \\
227.8 \\
229.2 \\
229.2 \\
143.8 \\
143.8\end{array}$ & $\begin{array}{l}38.06 \\
46.99 \\
46.99 \\
39.33 \\
36.30 \\
42.94 \\
29.88 \\
36.70 \\
32.86 \\
29.26 \\
41.79 \\
27.83 \\
32.65 \\
40.88 \\
57.28 \\
57.59 \\
57.59 \\
27.88 \\
27.88\end{array}$ \\
\hline 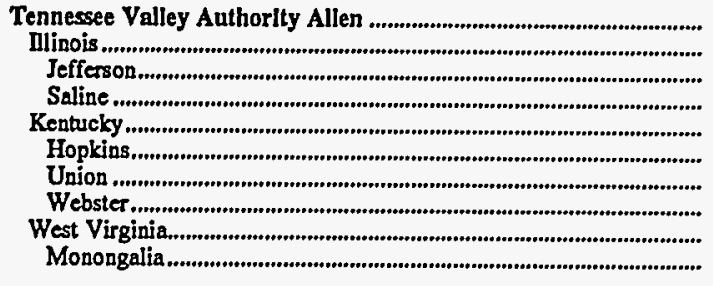 & $\begin{array}{r}873 \\
338 \\
166 \\
173 \\
459 \\
245 \\
13 \\
201 \\
76 \\
76\end{array}$ & $\begin{array}{l}12,040 \\
11,913 \\
11,746 \\
12,074 \\
12,207 \\
11,906 \\
12,200 \\
12,574 \\
11,600 \\
11,600\end{array}$ & $\begin{array}{l}1.98 \\
1.81 \\
1.79 \\
1.83 \\
2.13 \\
2.03 \\
2.37 \\
2.24 \\
1.80 \\
1.80\end{array}$ & $\begin{array}{l}1.64 \\
1.52 \\
1.52 \\
1.51 \\
1.75 \\
1.71 \\
1.94 \\
1.78 \\
1.55 \\
1.55\end{array}$ & $\begin{array}{r}8.42 \\
8.47 \\
7.69 \\
9.22 \\
8.54 \\
8.15 \\
12.00 \\
8.80 \\
7.50 \\
7.50\end{array}$ & $\begin{array}{l}116.9 \\
112.9 \\
112.5 \\
113.3 \\
120.5 \\
119.8 \\
117.8 \\
121.6 \\
111.9 \\
111.9\end{array}$ & $\begin{array}{l}28.15 \\
26.91 \\
26.44 \\
27.36 \\
29.43 \\
28.52 \\
28.75 \\
30.58 \\
25.96 \\
25.96\end{array}$ \\
\hline 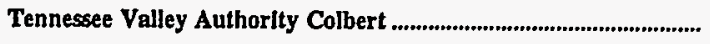 & 2,746 & 12,000 & 1.23 & 1.02 & 11.04 & 118.9 & 28.53 \\
\hline
\end{tabular}

See footnotes at end of table. 
Table B2. Profile of Coal Received at Table 1 Plants, 1995 (Continued)

\begin{tabular}{|c|c|c|c|c|c|c|c|}
\hline \multirow[b]{2}{*}{$\begin{array}{c}\text { Electric Uttllty Plant } \\
\text { Origin State } \\
\text { County }\end{array}$} & \multirow[b]{2}{*}{$\begin{array}{l}\text { Recelpts } \\
\text { (thousand } \\
\text { short tons) }\end{array}$} & \multicolumn{4}{|c|}{ Average Quallty } & \multicolumn{2}{|c|}{$\begin{array}{l}\text { Average Dellvered } \\
\text { Cost }\end{array}$} \\
\hline & & $\begin{array}{c}\text { Btu } \\
\text { (per } \\
\text { pound) }\end{array}$ & $\begin{array}{c}\text { Sulfur } \\
\text { (percent } \\
\text { by } \\
\text { welght) }\end{array}$ & $\begin{array}{c}\text { Sulfur } \\
\text { (pounds } \\
\text { per } \\
\text { MM Btu) }\end{array}$ & $\begin{array}{c}\text { Ash } \\
\text { (percent } \\
\text { by } \\
\text { welght) }\end{array}$ & $\begin{array}{l}\text { (cents } \\
\text { per } \\
\text { millilon } \\
\text { Bta) }\end{array}$ & $\begin{array}{l}\text { (dollars } \\
\text { per } \\
\text { short } \\
\text { ton) }\end{array}$ \\
\hline \multicolumn{8}{|l|}{ Tennessee Valley Authorlty Colbert } \\
\hline 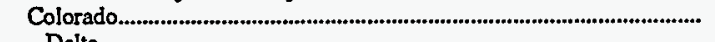 & 10 & 11,013 & 0.37 & 0.34 & 8.79 & 126.9 & 27.95 \\
\hline 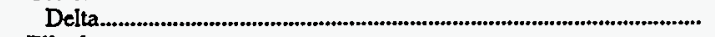 & 10 & 11,013 & .37 & .34 & 8.79 & 126.9 & 27.95 \\
\hline 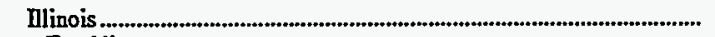 & 660 & 11,658 & 1.74 & 1.49 & 8.26 & 107.0 & 24.95 \\
\hline 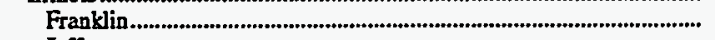 & 49 & 11,500 & 2.24 & 1.95 & 8.46 & 118.0 & 27.15 \\
\hline 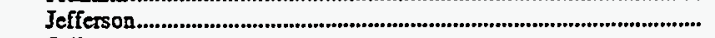 & 516 & 11,576 & 1.68 & 1.45 & 8.13 & 106.5 & 24.65 \\
\hline 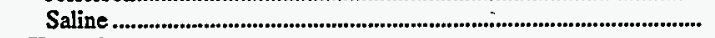 & 94 & 12,193 & 1.80 & 1.48 & 8.89 & 104.4 & 25.45 \\
\hline 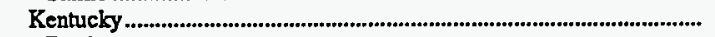 & 904 & 12,003 & 1.27 & 1.05 & 10.74 & 119.2 & 28.62 \\
\hline 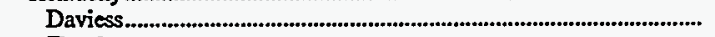 & 3 & 11,300 & 1.15 & 1.02 & 9.54 & 116.0 & 26.22 \\
\hline 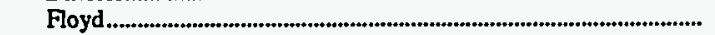 & 323 & 11,883 & .86 & .72 & 11.04 & 119.2 & 28.33 \\
\hline 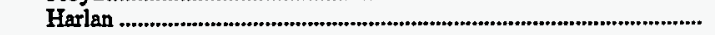 & 25 & 12,182 & .62 & .51 & 11.72 & 129.7 & 31.59 \\
\hline Johnson & 161 & 11,903 & 1.14 & .96 & 10.76 & 127.1 & 30.27 \\
\hline Knox & 17 & 11,832 & .82 & .69 & 11.80 & 113.0 & 26.74 \\
\hline 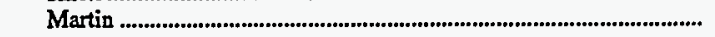 & 3 & 11,331 & .71 & .63 & 11.96 & 132.2 & 29.95 \\
\hline Perry & 7 & 12,307 & .78 & .63 & 9.96 & 115.1 & 28.32 \\
\hline 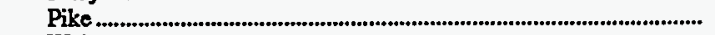 & 54 & 11,881 & 1.04 & .88 & 11.17 & 115.6 & 27.46 \\
\hline Webster & 310 & 12,204 & 1.89 & 1.55 & 10.21 & 115.4 & 28.16 \\
\hline Pennsylvania & 38 & 13,259 & 1.63 & 1.23 & 7.02 & 120.6 & 31.98 \\
\hline 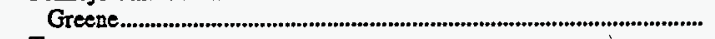 & 38 & 13,259 & 1.63 & 1.23 & 7.02 & 120.6 & 31.98 \\
\hline Tennessee. & 114 & 12,356 & .88 & .71 & 12.71 & 135.4 & 33.45 \\
\hline 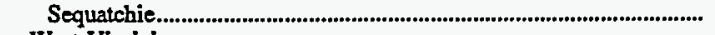 & 114 & 12,356 & .88 & .71 & 12.71 & 135.4 & 33.45 \\
\hline 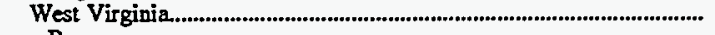 & 1,020 & 12,141 & .89 & .74 & 13.09 & 123.9 & 30.08 \\
\hline 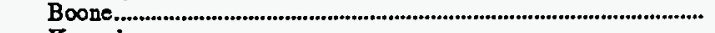 & 33 & 11,999 & 1.00 & .83 & 12.97 & 111.7 & 26.81 \\
\hline 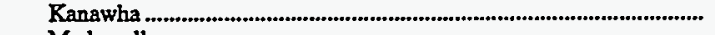 & 966 & 12,151 & .88 & .73 & 13.10 & 124.5 & 30.25 \\
\hline 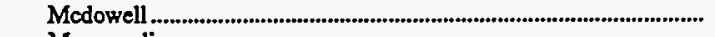 & 19 & 11,842 & 1.03 & .87 & 13.29 & 114.3 & 27.08 \\
\hline 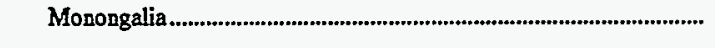 & 2 & 12,725 & 2.34 & 1.84 & 8.77 & 113.6 & 28.90 \\
\hline Tennessee Valley Authority Cumberland.............................................. & 8,619 & 11,637 & 2.83 & 2.43 & 8.97 & 102.4 & 23.84 \\
\hline 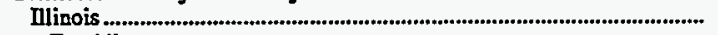 & 1,639 & 11,620 & 2.63 & 2.27 & 9.08 & 93.2 & 21.66 \\
\hline 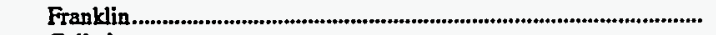 & 1,128 & 11,346 & 2.59 & 2.29 & 9.09 & 93.3 & 21.18 \\
\hline Gallatin & 199 & 12,722 & 2.76 & 2.17 & 8.90 & 96.7 & 24.60 \\
\hline 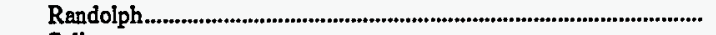 & 152 & 11,621 & 2.52 & 2.17 & 8.48 & 82.8 & 19.25 \\
\hline Saline & 159 & 12,182 & 2.89 & 2.37 & 9.76 & 97.1 & 23.67 \\
\hline Kentucky & 6,416 & 11,513 & 2.91 & 2.53 & 9.03 & 104.3 & 24.02 \\
\hline 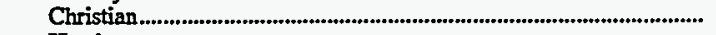 & 81 & 11,057 & 2.79 & 2.53 & 9.93 & 102.0 & 22.55 \\
\hline 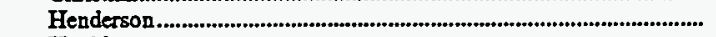 & 9 & 11,190 & 2.57 & 2.30 & 8.40 & 94.5 & 21.15 \\
\hline 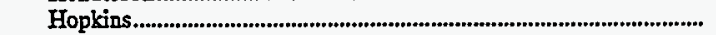 & 280 & 11,936 & 2.55 & 2.13 & 8.46 & 108.7 & 25.94 \\
\hline 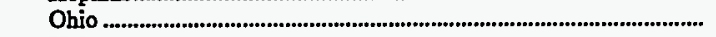 & 257 & 11,439 & 3.27 & 2.85 & 9.09 & 85.7 & 19.60 \\
\hline 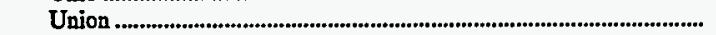 & 5,371 & 11,435 & 2.89 & 2.53 & 9.08 & 104.2 & 23.84 \\
\hline 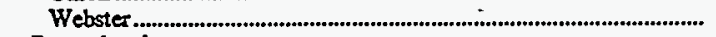 & 419 & 12,371 & 3.26 & 2.64 & 8.48 & 113.9 & 28.18 \\
\hline 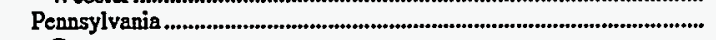 & 543 & 13,136 & 2.43 & 1.85 & 7.86 & 107.0 & 28.12 \\
\hline 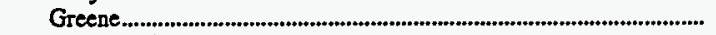 & 543 & 13,136 & 2.43 & 1.85 & 7.86 & 107.0 & 28.12 \\
\hline 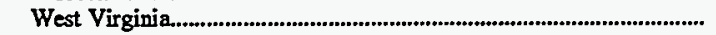 & 21 & 12,200 & 4.00 & 3.28 & 11.00 & 103.3 & 25.20 \\
\hline 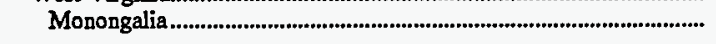 & 21 & 12,200 & 4.00 & 3.28 & 11.00 & 103.3 & 25.20 \\
\hline Tennessee Valley Anthority Gallatin & 2,322 & 12,264 & 204 & 1.67 & 9.50 & 122.7 & 30.09 \\
\hline Colorado & 23 & 11,600 & .70 & .60 & 9.75 & 141.6 & 32.86 \\
\hline 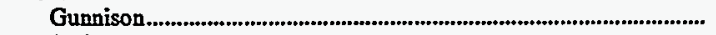 & 23 & 11,600 & .70 & .60 & 9.75 & 141.6 & 32.86 \\
\hline 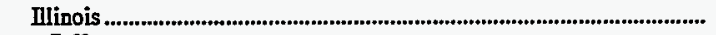 & 119 & 11,565 & 2.37 & 2.05 & 9.75 & 132.5 & 30.65 \\
\hline Jefferson & 18 & 11,519 & 1.66 & 1.44 & 7.33 & 136.0 & 31.34 \\
\hline Saline & 101 & 11,573 & 2.50 & 2.16 & 10.18 & 131.9 & 30.53 \\
\hline 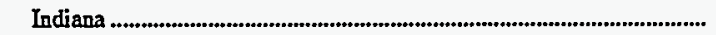 & 9 & 10,949 & 1.55 & 1.42 & 8.14 & 115.2 & 25.23 \\
\hline 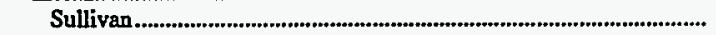 & 9 & 10,949 & 1.55 & 1.42 & 8.14 & 115.2 & 25.23 \\
\hline 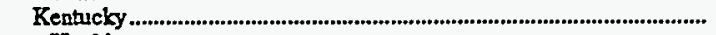 & 2,172 & 12,314 & 2.04 & 1.66 & 9.49 & 122.0 & 30.05 \\
\hline 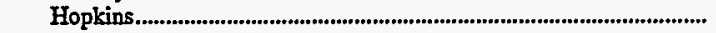 & 425 & 12,073 & 2.57 & 2.12 & 7.81 & 108.8 & 26.28 \\
\hline Perтy & 17 & 12,194 & 1.44 & 1.18 & 10.02 & 132.6 & 32.34 \\
\hline Union & 268 & 12,282 & 2.16 & 1.76 & 11.03 & 129.6 & 31.84 \\
\hline 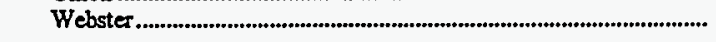 & 1,462 & 12,391 & 1.88 & 1.51 & 9.69 & 124.2 & 30.79 \\
\hline 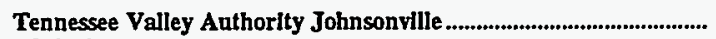 & 2,901 & 11,936 & 1.77 & 1.49 & 9.16 & 119.7 & 28.58 \\
\hline 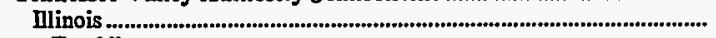 & 1,853 & 11,728 & 1.78 & 1.52 & 8.75 & 123.4 & 28.95 \\
\hline 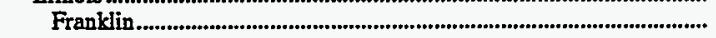 & 1,219 & 11,639 & 1.79 & 1.54 & 9.20 & 131.3 & 30.56 \\
\hline 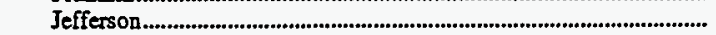 & 275 & 11,700 & 1.68 & 1.44 & 7.50 & 109.5 & 25.62 \\
\hline 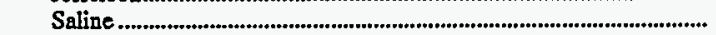 & 359 & 12,052 & 1.81 & 1.51 & 8.21 & 108.1 & 26.05 \\
\hline 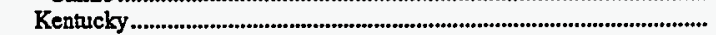 & 919 & 12,252 & 1.78 & 1.46 & 9.93 & 112.5 & 27.57 \\
\hline 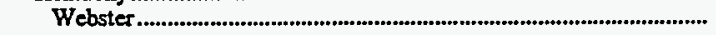 & 919 & 12,252 & 1.78 & 1.46 & 9.93 & 112.5 & 27.57 \\
\hline
\end{tabular}

See footnotes at end of table. 
Table B2. Profile of Coal Received at Table 1 Plants, 1995 (Continued)

\begin{tabular}{|c|c|c|c|c|c|c|c|}
\hline \multirow[b]{2}{*}{$\begin{array}{c}\text { Electric UtIlfty Plant } \\
\text { Origin State } \\
\text { County }\end{array}$} & \multirow[b]{2}{*}{$\begin{array}{l}\text { Recelpts } \\
\text { (thousand } \\
\text { short tons) }\end{array}$} & \multicolumn{4}{|c|}{ Average Quallty } & \multicolumn{2}{|c|}{$\begin{array}{c}\text { Average Dellvered } \\
\text { Cost }\end{array}$} \\
\hline & & $\begin{array}{l}\text { Btu } \\
\text { (per } \\
\text { pound) }\end{array}$ & $\begin{array}{c}\text { Sulfur } \\
\text { (percent } \\
\text { by } \\
\text { welght) }\end{array}$ & $\begin{array}{c}\text { Sulfur } \\
\text { (pounds } \\
\text { per } \\
\text { MM Bto) }\end{array}$ & $\begin{array}{c}\text { Ash } \\
\text { (percent } \\
\text { by } \\
\text { welght) }\end{array}$ & $\begin{array}{l}\text { (cents } \\
\text { per } \\
\text { milllon } \\
\text { Btu) }\end{array}$ & $\begin{array}{l}\text { (dollars } \\
\text { per } \\
\text { short } \\
\text { ton) }\end{array}$ \\
\hline 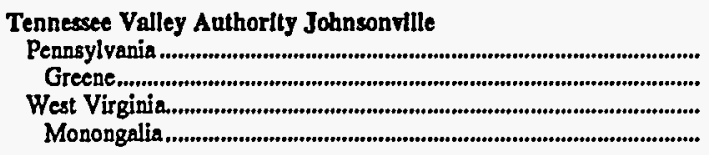 & $\begin{array}{l}73 \\
73 \\
56 \\
56\end{array}$ & $\begin{array}{l}13,040 \\
13,040 \\
12,211 \\
12,211\end{array}$ & $\begin{array}{l}1.59 \\
1.59 \\
1.58 \\
1.58\end{array}$ & $\begin{array}{l}1.22 \\
1.22 \\
1.29 \\
1.29\end{array}$ & $\begin{array}{r}7.33 \\
7.33 \\
12.62 \\
12.62\end{array}$ & $\begin{array}{l}121.5 \\
121.5 \\
118.3 \\
118.3\end{array}$ & $\begin{array}{l}31.68 \\
31.68 \\
28.88 \\
28.88\end{array}$ \\
\hline 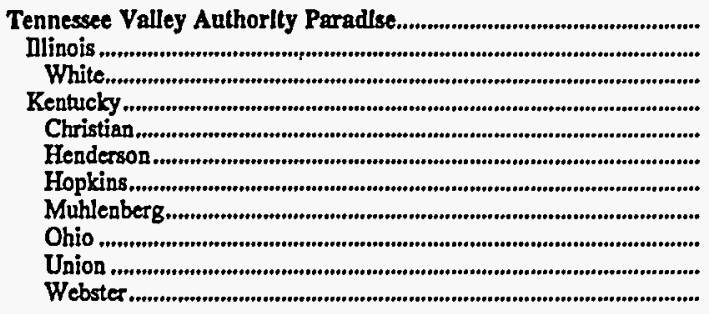 & $\begin{array}{r}7,095 \\
22 \\
22 \\
7,073 \\
1,419 \\
225 \\
1,165 \\
2,263 \\
587 \\
275 \\
1,137\end{array}$ & $\begin{array}{l}10,677 \\
11,649 \\
11,649 \\
10,674 \\
10,479 \\
11,231 \\
10,840 \\
10,317 \\
11,366 \\
10,252 \\
11,091\end{array}$ & $\begin{array}{l}4.35 \\
2.83 \\
2.83 \\
4.35 \\
4.56 \\
2.64 \\
3.96 \\
4.64 \\
3.58 \\
3.94 \\
4.77\end{array}$ & $\begin{array}{l}4.07 \\
2.43 \\
2.43 \\
4.08 \\
4.35 \\
2.35 \\
3.65 \\
4.50 \\
3.15 \\
3.84 \\
4.30\end{array}$ & $\begin{array}{r}17.90 \\
8.80 \\
8.80 \\
17.93 \\
16.11 \\
8.59 \\
18.10 \\
20.60 \\
10.84 \\
18.86 \\
19.99\end{array}$ & $\begin{array}{r}92.7 \\
112.5 \\
112.5 \\
92.7 \\
85.4 \\
91.4 \\
88.8 \\
95.4 \\
80.2 \\
89.7 \\
107.7\end{array}$ & $\begin{array}{l}19.81 \\
26.20 \\
26.20 \\
19.79 \\
17.90 \\
20.54 \\
19.24 \\
19.69 \\
18.23 \\
18.38 \\
23.88\end{array}$ \\
\hline 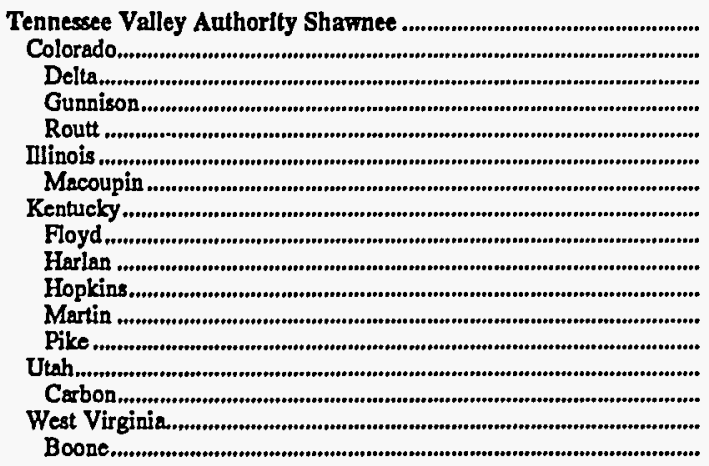 & $\begin{array}{r}3,821 \\
1,781 \\
30 \\
1,018 \\
734 \\
11 \\
11 \\
1,518 \\
38 \\
1,009 \\
422 \\
3 \\
45 \\
12 \\
12 \\
499 \\
499\end{array}$ & $\begin{array}{l}11,861 \\
11,536 \\
11,336 \\
11,804 \\
11,174 \\
10,700 \\
10,700 \\
12,009 \\
11,776 \\
12,143 \\
11,653 \\
12,000 \\
12,542 \\
12,395 \\
12,395 \\
12,581 \\
12,581\end{array}$ & $\begin{array}{r}.84 \\
.49 \\
.50 \\
.49 \\
.48 \\
3.65 \\
3.65 \\
1.30 \\
.69 \\
.67 \\
2.92 \\
.72 \\
.63 \\
.65 \\
.65 \\
.66 \\
.66\end{array}$ & $\begin{array}{r}.71 \\
.42 \\
.44 \\
.41 \\
.43 \\
.4 .41 \\
3.41 \\
11.08 \\
.59 \\
.55 \\
2.50 \\
.60 \\
.50 \\
.52 \\
.52 \\
.52 \\
.52\end{array}$ & $\begin{array}{r}10.83 \\
9.42 \\
8.01 \\
8.53 \\
10.72 \\
8.50 \\
8.50 \\
12.30 \\
12.69 \\
13.04 \\
10.82 \\
13.50 \\
9.24 \\
9.98 \\
9.98 \\
11.42 \\
11.42\end{array}$ & $\begin{array}{r}121.4 \\
121.4 \\
98.3 \\
123.3 \\
119.6 \\
91.9 \\
91.9 \\
118.9 \\
122.7 \\
122.3 \\
107.9 \\
118.8 \\
137.9 \\
144.0 \\
144.0 \\
128.4 \\
128.4\end{array}$ & $\begin{array}{l}28.79 \\
28.02 \\
22.28 \\
29.11 \\
26.73 \\
19.67 \\
19.67 \\
28.56 \\
28.91 \\
29.71 \\
25.14 \\
28.50 \\
34.59 \\
35.71 \\
35.71 \\
32.31 \\
32.31\end{array}$ \\
\hline 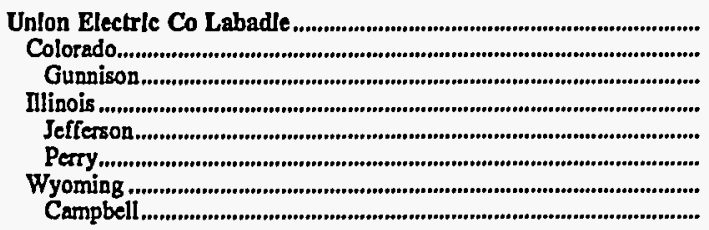 & $\begin{array}{r}6,951 \\
395 \\
395 \\
1,937 \\
519 \\
1,418 \\
4,619 \\
4,619\end{array}$ & $\begin{array}{r}9,591 \\
11,750 \\
11,750 \\
11,280 \\
11,500 \\
11,200 \\
8,698 \\
8,698\end{array}$ & $\begin{array}{r}.92 \\
.47 \\
.47 \\
2.61 \\
1.27 \\
3.10 \\
.24 \\
.24\end{array}$ & $\begin{array}{r}.96 \\
.40 \\
.40 \\
2.31 \\
1.10 \\
2.77 \\
.28 \\
.28\end{array}$ & $\begin{array}{r}6.65 \\
9.60 \\
9.60 \\
10.61 \\
12.00 \\
10.10 \\
4.73 \\
4.73\end{array}$ & $\begin{array}{r}110.6 \\
160.2 \\
160.2 \\
134.6 \\
142.1 \\
131.7 \\
91.8 \\
91.8\end{array}$ & $\begin{array}{l}21.22 \\
37.65 \\
37.65 \\
30.36 \\
32.67 \\
29.51 \\
15.98 \\
15.98\end{array}$ \\
\hline 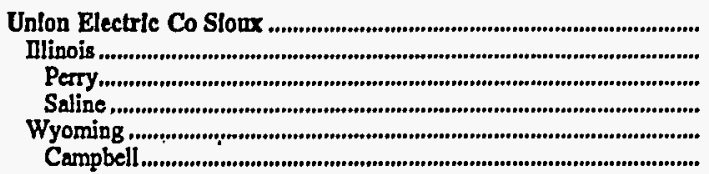 & $\begin{array}{r}2,108 \\
583 \\
573 \\
10 \\
1,525 \\
1,525\end{array}$ & $\begin{array}{r}9,119 \\
11,209 \\
11,200 \\
11,700 \\
8,320 \\
8,320\end{array}$ & $\begin{array}{r}1.13 \\
3.07 \\
3.10 \\
1.28 \\
.38 \\
.38\end{array}$ & $\begin{array}{r}1.24 \\
2.74 \\
2.77 \\
1.09 \\
.46 \\
.46\end{array}$ & $\begin{array}{r}6.62 \\
10.05 \\
10.10 \\
7.10 \\
5.31 \\
5.31\end{array}$ & $\begin{array}{r}108.1 \\
144.9 \\
144.9 \\
147.2 \\
89.1 \\
89.1\end{array}$ & $\begin{array}{l}19.71 \\
32.48 \\
32.45 \\
34.44 \\
14.83 \\
14.83\end{array}$ \\
\hline 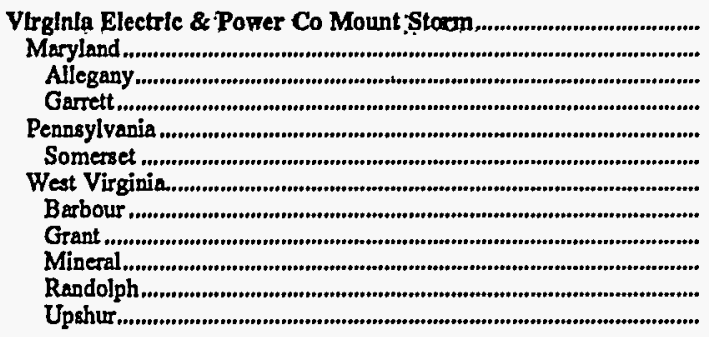 & $\begin{array}{r}4,230 \\
1,573 \\
79 \\
1,494 \\
32 \\
32 \\
2,625 \\
123 \\
2,426 \\
53 \\
4 \\
19\end{array}$ & $\begin{array}{l}12,341 \\
12,563 \\
11,904 \\
12,598 \\
11,683 \\
11,683 \\
12,216 \\
11,770 \\
12,251 \\
11,811 \\
11,782 \\
11,952\end{array}$ & $\begin{array}{l}1.68 \\
1.60 \\
1.66 \\
1.60 \\
1.55 \\
1.55 \\
1.73 \\
1.75 \\
1.73 \\
1.66 \\
1.86 \\
1.49\end{array}$ & $\begin{array}{l}1.36 \\
1.28 \\
1.40 \\
1.27 \\
1.33 \\
1.33 \\
1.41 \\
1.49 \\
1.41 \\
1.40 \\
1.58 \\
1.25\end{array}$ & $\begin{array}{l}14.45 \\
13.51 \\
16.89 \\
13.33 \\
16.46 \\
16.46 \\
14.99 \\
17.98 \\
14.83 \\
14.76 \\
13.37 \\
16.56\end{array}$ & $\begin{array}{l}126.8 \\
123.2 \\
110.2 \\
123.8 \\
108.0 \\
108.0 \\
129.3 \\
110.4 \\
130.7 \\
114.1 \\
100.0 \\
110.4\end{array}$ & $\begin{array}{l}31.31 \\
30.95 \\
26.24 \\
31.20 \\
25.24 \\
25.24 \\
31.59 \\
25.98 \\
32.03 \\
26.94 \\
23.56 \\
26.39\end{array}$ \\
\hline 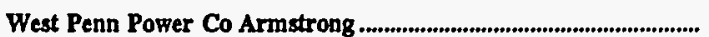 & 551 & 12,598 & 1.68 & 1.33 & 10.70 & 129.5 & 32.63 \\
\hline
\end{tabular}

See footnotes at end of table. 
Table B2. Profile of Coal Received at Table 1 Plants, 1995 (Continued)

\begin{tabular}{|c|c|c|c|c|c|c|c|}
\hline \multirow{2}{*}{$\begin{array}{c}\text { Electric Utllity Plant } \\
\text { Origin State } \\
\text { County }\end{array}$} & \multirow{2}{*}{$\begin{array}{l}\text { Recejpts } \\
\text { (thousand } \\
\text { short tons) }\end{array}$} & \multicolumn{4}{|c|}{ Average Quallty } & \multicolumn{2}{|c|}{$\begin{array}{l}\text { Average Dellvered } \\
\text { Cost }\end{array}$} \\
\hline & & $\begin{array}{c}\text { Btu } \\
\text { (per } \\
\text { pound) }\end{array}$ & $\begin{array}{c}\text { Sulfur } \\
\text { (percent } \\
\text { by } \\
\text { relght) }\end{array}$ & $\begin{array}{c}\text { Sulfur } \\
\text { (pounds } \\
\text { per } \\
\text { MM Btu) }\end{array}$ & $\begin{array}{c}\text { Ash } \\
\text { (percent } \\
\text { by } \\
\text { welght) }\end{array}$ & $\begin{array}{c}\text { (cents } \\
\text { per } \\
\text { million } \\
\text { Btu) }\end{array}$ & $\begin{array}{l}\text { (dollars } \\
\text { per } \\
\text { short } \\
\text { ton) }\end{array}$ \\
\hline \multicolumn{8}{|l|}{ West Penn Power Co Armstrong } \\
\hline 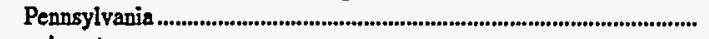 & 551 & 12,598 & 1.68 & 1.33 & 10.70 & 129.5 & 32.63 \\
\hline 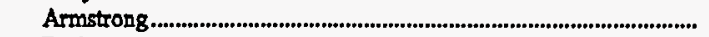 & 72 & 12,278 & 1.94 & 1.58 & 11.68 & 99.9 & 24.54 \\
\hline 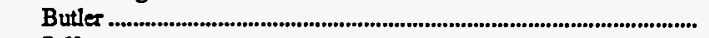 & 29 & 12,110 & 1.97 & 1.63 & 12.37 & 99.1 & 24.01 \\
\hline Jefferson & 450 & 12,681 & 1.62 & 1.28 & 10.43 & 136.0 & 34.49 \\
\hline West Penn Porrer Co Hatfleld & 3,361 & 13,013 & 231 & 1.77 & 8.86 & 130.9 & 34,06 \\
\hline Pennsylvania & 485 & 13,021 & 2.30 & 1.76 & 8.77 & 130.7 & 34.03 \\
\hline 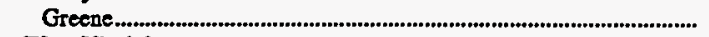 & 485 & 13,021 & 2.30 & 1.76 & 8.77 & 130.7 & 34.03 \\
\hline 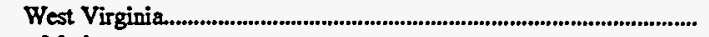 & 2,877 & 13,012 & 2.31 & 1.77 & 8.87 & 130.9 & 34.07 \\
\hline 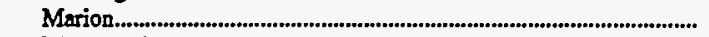 & 14 & 13,149 & 2.25 & 1.71 & 7.80 & 123.8 & 32.56 \\
\hline 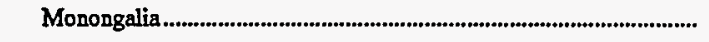 & 2,862 & 13,011 & 2.31 & 1.77 & 8.88 & 130.9 & 34.07 \\
\hline Wisconsin Electrie Power Co Oak Creek & 2,091 & 12,289 & .60 & .49 & 11.21 & 150.8 & 37.08 \\
\hline 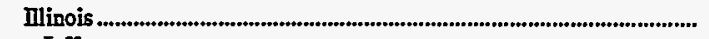 & 258 & 12,227 & .88 & .72 & 7.49 & 126.2 & 30.87 \\
\hline 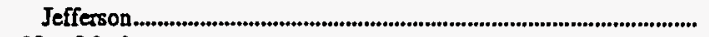 & 258 & 12,227 & .88 & .72 & 7.49 & 126.2 & 30.87 \\
\hline 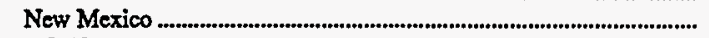 & 1,578 & 12,372 & .50 & .41 & 12.53 & 158.1 & 39.13 \\
\hline Colfax & 1,578 & 12,372 & .50 & .41 & 12.53 & 158.1 & 39.13 \\
\hline 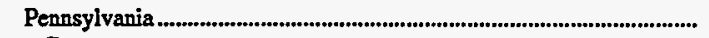 & 124 & 13,146 & 1.54 & 1.17 & 6.70 & 133.0 & 34.98 \\
\hline Greene & 124 & 13,146 & 1.54 & 1.17 & 6.70 & 133.0 & 34.98 \\
\hline 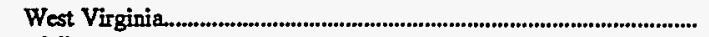 & 57 & 12,908 & .66 & .51 & 9.39 & 152.7 & 39.42 \\
\hline 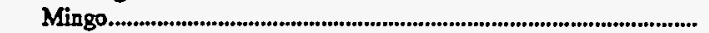 & 57 & 12,908 & .66 & .51 & 9.39 & 152.7 & 39.42 \\
\hline Wyoming & 73 & 8,809 & .18 & .20 & 4.92 & 93.9 & 16.54 \\
\hline Campbell & 73 & 8,809 & .18 & .20 & 4.92 & 93.9 & 16.54 \\
\hline 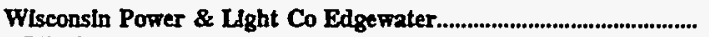 & 2,633 & 8,831 & 34 & .38 & 5.57 & 122.8 & $\mathbf{2 1 . 7 0}$ \\
\hline Illinois & 108 & 12,127 & 1.00 & .83 & 5.74 & 157.9 & 38.29 \\
\hline Jeffersoa & 108 & 12,127 & 1.00 & .83 & 5.74 & 157.9 & 38.29 \\
\hline 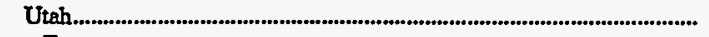 & 72 & 12,585 & .55 & .44 & 8.02 & 154.4 & 38.87 \\
\hline 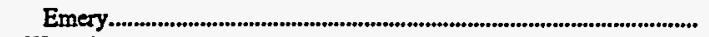 & 72 & 12,585 & .55 & .44 & 8.02 & 154.4 & 38.87 \\
\hline 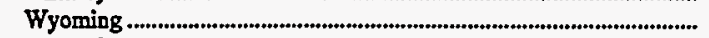 & 2,452 & 8,576 & .30 & .35 & 5.49 & 119.3 & 20.46 \\
\hline 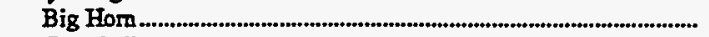 & 111 & 10,398 & .49 & .47 & 6.63 & 144.8 & 30.12 \\
\hline Campbell & 2,342 & 8,490 & .29 & .34 & 5.43 & 117.8 & 20.00 \\
\hline 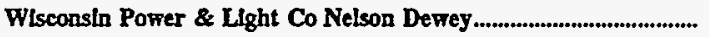 & 588 & 9,472 & 37 & 39 & 4.33 & 119.3 & 22.61 \\
\hline 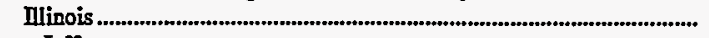 & 30 & 12,126 & .95 & .79 & 5.09 & 140.0 & 33.96 \\
\hline 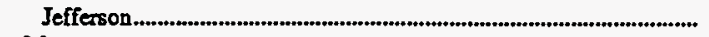 & 30 & 12,126 & .95 & .79 & 5.09 & 140.0 & 33.96 \\
\hline 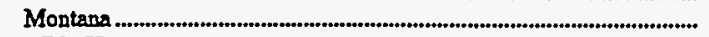 & 499 & 9,394 & .34 & .36 & 4.14 & 118.3 & 22.23 \\
\hline Big Hom & 499 & 9,394 & .34 & .36 & 4.14 & 118.3 & 22.23 \\
\hline Wyoming & 59 & 8,763 & .33 & .37 & 5.51 & 113.9 & 19.96 \\
\hline 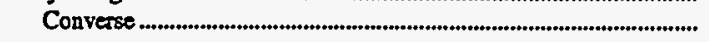 & 59 & 8,763 & .33 & .37 & 5.51 & 113.9 & 19.96 \\
\hline Wisconsin Pablic Service Corp Palliam & 1,171 & 8,834 & .21 & .24 & 4.54 & 1153 & 20.36 \\
\hline 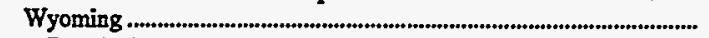 & 1,171 & 8,834 & .21 & .24 & 4.54 & 115.3 & 20.36 \\
\hline Campbell & 1,171 & 8,834 & .21 & .24 & 4.54 & 115.3 & 20.36 \\
\hline Total & 226,244 & 11,406 & 1.62 & 1.42 & 9.39 & 129.3 & 29.49 \\
\hline
\end{tabular}

1 Refers to coal in which the county of origin in not known.

2 The Tampa Electric Company reports coal destined for the Big Bend power plant as it is received at this facility located in Louisiana. The cost reported under Davant Transfer is the weighted average cost of coal delivered to this facility. The Tampa Electric Company incurs additional costs for transporting coal from Davant to the Big Bend power plant located in Florida.

- = Number less than 0.5 thousand short tons.

Notes: - Plants affected by Phase 1 but not shown in this table include the following: Edgewater (Ohio Edison) is using natural gas. Northport and Port Jefferson (Long Island Lighting) use petroleum Des Moines (Midwest Power) is out of service. Breed (Indiana Michigan Power) is retired. • Totals may not equal sum of components because of independent rounding. - Data are for electric generating plants with a total steam-electric and combined-cycle nameplate capacity of 50 or more megawatts.

Source: Federal Energy Regulatory Commission, FERC Form 423, "Monthly Report of Cost and Quality of Fuels for Electric Plants." 
Appendix C

Costs and Characteristics of Selected Phase I Units, by Utility 


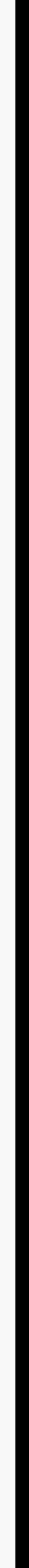




\section{Appendix C}

\section{Costs and Characteristics of Selected Phase I Units, by Utility}

This appendix presents detailed information pertaining to the compliance activities of the six utilities discussed in Chapter 2 . These utilities were selected to obtain a representative sample of generating capacities, sulfur dioxide $\left(\mathrm{SO}_{2}\right)$ emissions, locations, and initial compliance strategies. Also, the willingness to participate and share information was essential. The six utilities are Cincinnati Gas and Electric Company, Georgia Power Company, Illinois Power Company, Potomac Electric Power Company, Pennsylvania Power and Light Company, and Southern Indiana Gas and Electric Company.

Information on allowance allocations and sulfur dioxide $\left(\mathrm{SO}_{2}\right)$ emissions, compliance strategies and compliance costs is provided for each unit. Cost information covers $\mathrm{SO}_{2}$, nitrogen oxides (NO ${ }_{x}$ ), and Continuous Emission
Monitoring System (CEMS) components. Capital costs and operations and maintenance costs are also provided.

A detailed analysis of compliance strategies and preliminary compliance costs for these six utilities was presented in a previous report. ${ }^{108}$ This report updates the earlier analysis by (1) taking into consideration substitution units, (2) finalizing cost data, and (3) accounting for changes in compliance strategies.

Each utility was asked to update its compliance strategies and costs for all units affected by Phase I and to provide similar information on Phase II units. Definitive plans for Phase II have not been developed. Further, because of increased competition in the electric industry, some utilities are reluctant to share detailed information.

${ }^{108}$ Energy Information Administration, Acid Rain Compliance Strategies for the Clean Air Act Amendments of 1990, DOE/EIA-0582 (Washington, DC, March 1994). 


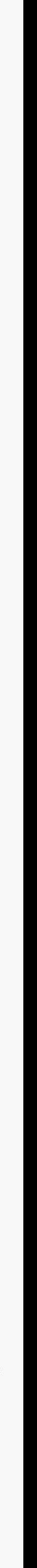




\begin{tabular}{|c|c|c|c|c|c|c|c|c|c|c|}
\hline Type of Unit & Unit & Plant & State & $\begin{array}{c}\text { Year } \\
\text { Online }\end{array}$ & $\begin{array}{c}\text { Affected } \\
\text { Utility } \\
\text { Owned } \\
\text { Nameplate } \\
\text { Capacity } \\
\text { (MW) }\end{array}$ & $\begin{array}{c}1995 \\
\text { Allocation } \\
\text { of } \mathrm{SO}_{2} \\
\text { Allowances }\end{array}$ & $\begin{array}{c}\text { Allowances } \\
\text { Deducted for } \\
\text { Emissions } \\
\text { (tons) }\end{array}$ & $\begin{array}{c}\text { Difference } \\
\text { Between } \\
\text { Total and } \\
1995 \\
\text { Emissions } \\
\text { Deductions } \\
\end{array}$ & $\begin{array}{c}\text { Allowances }^{\mathrm{a}} \\
\text { Carried } \\
\text { Over } \\
\text { to } 1996\end{array}$ & $\begin{array}{c}1995 \mathrm{SO}_{2} \\
\text { Compllance } \\
\text { Strategy }\end{array}$ \\
\hline \multicolumn{11}{|c|}{ Cincinnati Gas \& Electrlc Company } \\
\hline Table $1 \ldots \ldots \ldots$ & 5 & Miami Fort & $\mathrm{OH}$ & 1949 & 100 & 834 & 263 & 571 & 571 & Fuel Swilch \\
\hline Table $1 \ldots . . .$. & 5 & Beckjord & $\mathrm{OH}$ & 1962 & 238 & 9,822 & 8,347 & 1,475 & 4,525 & Fuel Switch \\
\hline Table $1 \ldots . . .$. & 6 & Beckjord * & $\mathrm{OH}$ & 1969 & 158 & 9,463 & 6,555 & 2,908 & 3,213 & Fuel Switch \\
\hline Table $1 \ldots . . .$. & 4 & Conesville * & $\mathrm{OH}$ & 1973 & 312 & 21,385 & 25,176 & $(3,791)$ & 8,498 & Allowances \\
\hline Substitution...... & 2 & East Bend* & KY & 1981 & 414 & 12,038 & 7,851 & 4,187 & 3,425 & Scrubber \\
\hline Substltution ...... & 1 & J. M. Stuart" & $\mathrm{OH}$ & 1971 & 238 & 16,064 & 8,916 & 7,148 & 7,109 & Fuel Switch \\
\hline \multicolumn{11}{|c|}{ Georgla Power Company } \\
\hline Table $1 . . . . . .$. & 1 & Bowen & GA & 1971 & 806 & 54,838 & 32,617 & 22,221 & 4,217 & Fuel Switch \\
\hline Table $1 . . . . . .$. & 2 & Bowen & GA & 1972 & 789 & 53,329 & 39,641 & 13,688 & 5,684 & Fuel Switch \\
\hline Table $1 \ldots . .$. & 3 & Bowen & GA & 1974 & 952 & 69,862 & 42,137 & 27,725 & 10,221 & Fuel Switch \\
\hline Table $1 \ldots . .$. & 4 & Bowen & GA & 1975 & 952 & 69,852 & 46,258 & 23,594 & 6,090 & Fuel Switch \\
\hline Table $1 \ldots . . .$. & 1 & Hammond & GA & 1954 & 125 & 8,549 & 2,466 & 6,083 & 6,083 & Fuel Switch \\
\hline Table $1 \ldots \ldots$. & 2 & Hammond & GA & 1954 & 125 & 8,977 & 2,466 & 6,511 & 6,511 & Fuel Switch \\
\hline Table $1 \ldots . .$. & 3 & Hammond & GA & 1955 & 125 & 8,676 & 2,466 & 6,210 & 6,210 & Fuel Switch \\
\hline Table $1 \ldots . .$. & 4 & Hammond & GA & 1970 & 578 & 36,650 & 14,297 & 22,353 & 14,353 & Fuel Switch \\
\hline Table $1 \ldots . .$. & 1 & McDonough & $\mathrm{GA}$ & 1963 & 299 & 33,290 & 9,793 & 23,497 & 11,285 & Fuel Switch \\
\hline Table 1 ........ & 5 & Yates & GA & 1958 & 156 & 9,162 & 1,940 & 7,222 & 7,222 & Fuel Switch \\
\hline Table $1 \ldots . .$. & 6 & Yates & GA & 1974 & 404 & 28,726 & 6,535 & 22,191 & 13,718 & Fuel Switch \\
\hline Table $1 \ldots . .$. & 7 & Yates & GA & 1974 & 404 & 22,318 & 5,683 & 16,635 & 8,491 & Fuel Switch \\
\hline Table $1 \ldots . .$. & 1 & Gaston * & $\mathrm{AL}$ & 1960 & 136 & 8,812 & 4,009 & 4,803 & 4,804 & Fuel Switch \\
\hline Table $1 \ldots . . .$. & 2 & Gaston * & $A L$ & 1960 & 136 & 9,026 & 3,758 & 5,268 & 5,269 & Fuel Switch \\
\hline Table $1 \ldots . . .$. & 3 & Gaston * & $A L$ & 1961 & 136 & 8,914 & 4,893 & 4,021 & 4,022 & Fuel Switch \\
\hline Table $1 \ldots . .$. & ST4 & Gaston * & $A L$ & 1962 & 122 & 9,387 & 3,626 & 5,761 & 5,761 & Fuel Switch \\
\hline Substitution...... & ST1 & Arkwright & GA & 1941 & 46 & 2,437 & 784 & 1,653 & 1,653 & Fuel Switch \\
\hline Substitution ...... & ST2 & Arkwright & GA & 1942 & 46 & 2,240 & 783 & 1,457 & 1,457 & Fuel Switch \\
\hline Substitution ...... & 3 & Arkwright & GA & 1943 & 40 & 3,944 & 783 & 3,161 & 3,161 & Fuel Switch \\
\hline Substltution ...... & 4 & Arkwright & GA & 1948 & 49 & 3,159 & 784 & 2,375 & 2,375 & Fuel Switch \\
\hline Substifution ...... & 1 & Harlee Branch & GA & 1965 & 299 & 19,221 & 13,715 & 5,506 & 5,506 & Fuel Switch \\
\hline Substltution ...... & 2 & Harlee Branch & GA & 1967 & 359 & 22,735 & 13,715 & 9,020 & 9,020 & Fuel Switch \\
\hline Substitultion ...... & 3 & Harlee Branch & GA & 1968 & 544 & 31,280 & 27,014 & 4,266 & 4,266 & Fuel Switch \\
\hline Substitution ...... & 4 & Harlee Branch & GA & 1969 & 544 & 31,042 & 27,015 & 4,027 & 4,027 & Fuel Switch \\
\hline Substitutlon ...... & 3 & Mitchell & GA & 1964 & 163 & 10,792 & 3,570 & 7,222 & 7,222 & Fuel Switch \\
\hline Substitution ...... & 3 & Scherer* & GA & 1986 & 75 & 0 & 17,151 & $(17,151)$ & 849 & Fuel Switch \\
\hline Total for Utility .. & & & & & 10,252 & 715,187 & 372,586 & 342,601 & 211,835 & \\
\hline
\end{tabular}

See notes at end of table. 


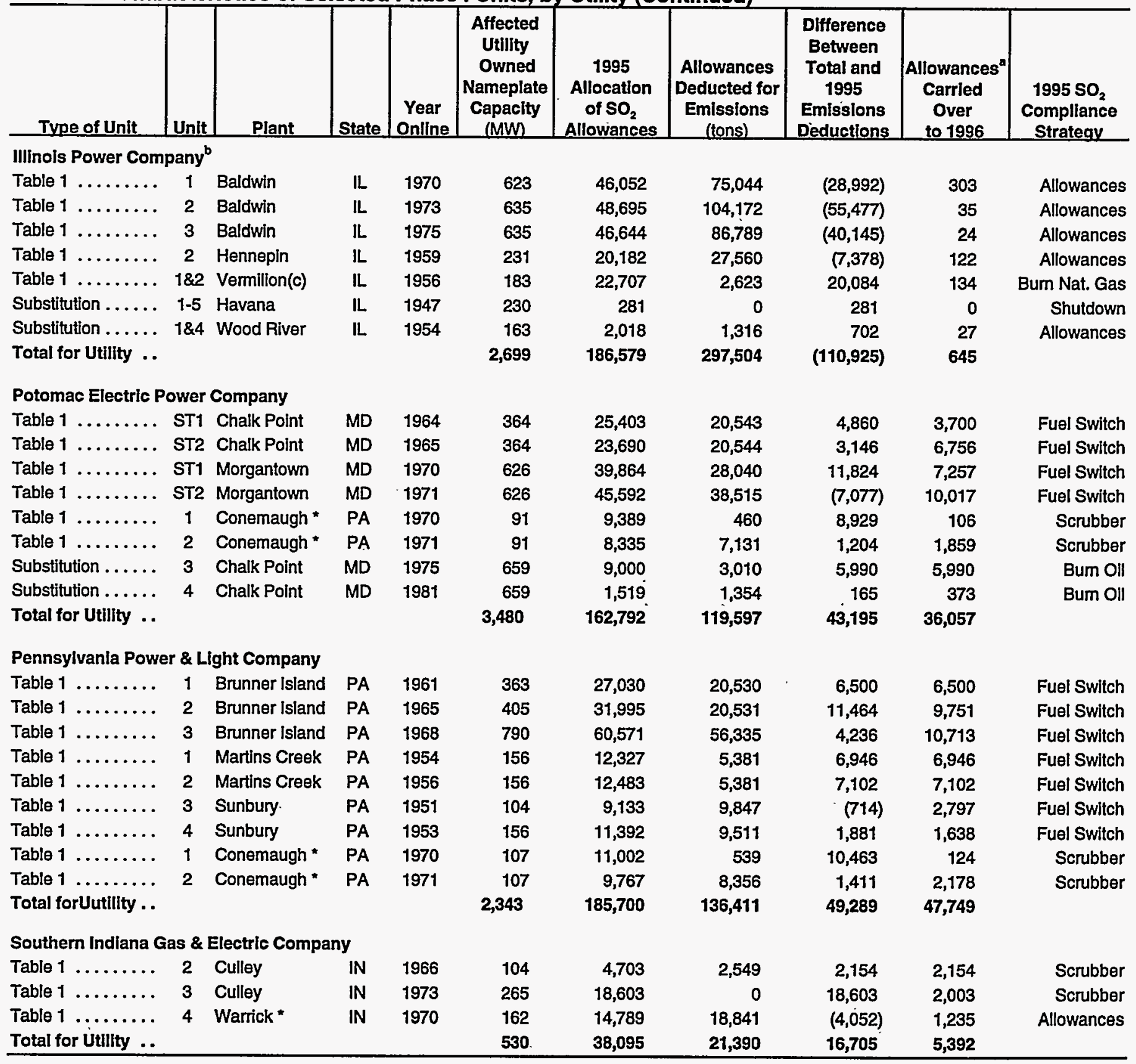

\footnotetext{
a Allowances carried over to 1996 may not equal the differences between allocated and 1995 emissions (e.g., Cincinnati Gas and Electric) due to purchases or sales of additional allowances. The data in this table do not account for purchases and sale transactions of the utility.

billinois Power purchased enough emission allowances to cover its 1995 emissions.

'Vermillion 1 is a substitution unit.

$\mathrm{SO}_{2}=$ Sulfur dioxide.

$M W=$ Megawatt.

- = Plant jointly owned by more than one utility.

Sources: Personal contact with llinois Power, Pennsylvania Power and Light, Potomac Electric Power, Cincinnati Gas and Electric, Georgia Power, and Southem Indiana Gas and Electric; Environmental Protection Agency, "1995 Compliance Results Acld Rain Program," EPA430-R-96-012 (Washington, DC, July 1996).
} 
Table C2. Cost of Phase I Compliance for Selected Units, by Utility

\begin{tabular}{|c|c|c|c|c|c|c|c|c|c|c|c|c|c|c|c|}
\hline \multirow{3}{*}{\multicolumn{3}{|c|}{ Iype of Unit }} & \multirow{3}{*}{ Unit } & \multirow[b]{3}{*}{ Plant } & \multirow{3}{*}{$\begin{array}{c}\begin{array}{c}\text { Number } \\
\text { of }\end{array} \\
\text { Low-NOx } \\
\text { Burners }\end{array}$} & \multirow{3}{*}{\multicolumn{2}{|c|}{\begin{tabular}{|l|l|} 
Number & $\begin{array}{c}\text { Number } \\
\text { of }\end{array}$ \\
of CEMs & Scrubbers \\
\end{tabular}}} & \multicolumn{2}{|c|}{$\mathrm{SO}_{2}$ Control } & \multirow{2}{*}{$\begin{array}{c}\text { Nox } \\
\text { Control } \\
\text { Capital } \\
\text { Cost } \\
\end{array}$} & \multicolumn{2}{|c|}{ CEMS } & \multirow{3}{*}{$\begin{array}{l}\text { Total } \\
\text { Capital } \\
\text { Cost }\end{array}$} & \multirow{3}{*}{$\begin{array}{l}\text { Annual } \\
\text { O\&M } \\
\text { Cost } \\
\end{array}$} & \multirow{3}{*}{$\begin{array}{c}\text { Average } \\
\text { Capital } \\
\text { Cost } \\
\text { (dollars/KW } \\
\text { affected) } \\
\end{array}$} \\
\hline & & & & & & & & $\begin{array}{c}\text { Capital } \\
\text { Cost }\end{array}$ & $\begin{array}{l}\text { O\&M } \\
\text { Cost } \\
\end{array}$ & & $\begin{array}{c}\text { Capital } \\
\text { Cost }\end{array}$ & $\begin{array}{l}\text { O\&M } \\
\text { Cost } \\
\end{array}$ & & & \\
\hline & & & & & & & & \multicolumn{5}{|c|}{ million dollars } & & & \\
\hline $\bar{\Xi}$ & \multicolumn{7}{|c|}{ Cincinnati Gas \& Electric Company } & & & & & & & & \\
\hline 总 & Table 1 & $\ldots \ldots \ldots$ & 5 & Miami Fort & 0.0 & 0.5 & 0.0 & 0.00 & 0.00 & 0.00 & 0.59 & c & 0.59 & 0.00 & 5.90 \\
\hline ב⿱乛龰ㅁ & Table 1 & $\ldots \ldots \ldots$ & 6 & Miami Fort & 0.0 & 0.5 & 0.0 & 2.24 & c & 0.00 & 0.62 & c & 2.86 & 0.00 & 17.51 \\
\hline$\overline{0}$ & Table 1 & $\ldots \ldots \ldots$ & 7 & Miami Fort * & 0.0 & 0.6 & 0.0 & 4.89 & c & 0.00 & 0.52 & c & 5.41 & 0.00 & 16.90 \\
\hline $\int_{5}^{5}$ & Table 1 & $\ldots \ldots \ldots$ & 5 & Beckjord & 1.0 & 1.0 & 0.0 & 5.28 & c & 5.00 & 0.90 & $c$ & 11.17 & 0.00 & 46.94 \\
\hline$\underline{3}$ & Table 1 & $\ldots \ldots \ldots$ & 6 & Beckjord * & 0.4 & 0.4 & 0.0 & 0.00 & 0.00 . & 1.90 & 0.29 & c & 2.19 & 0.00 & 13.89 \\
\hline 产 & Table 1 & $\ldots \ldots \ldots$ & 4 & Conesville * & 0.0 & 0.4 & 0.0 & 0.00 & $\mathrm{~b}$ & 0.00 & b & c & b & 0.00 & b \\
\hline 范 & \multicolumn{2}{|c|}{ Substitution ... } & 2 & East Bend" & 0.0 & 0.7 & 1.0 & b & b & 0.00 & 0.61 & $b$ & 0.61 . & b & 1.47 \\
\hline 苛 & \multicolumn{2}{|c|}{ Substitution } & 1 & J. M. Stuart" & 0.0 & 0.4 & 0.0 & b & $\mathrm{b}$ & 0.00 & b & b & b & b & b \\
\hline .9 & \multicolumn{2}{|c|}{ Substitution } & 2 & J. M. Stuart* & 0.0 & 0.4 & 0.0 & b & $b$ & 0.00 & b & b & b & b & b \\
\hline$\frac{m}{\mathrm{~m}}$ & \multicolumn{2}{|c|}{ Substitution } & 3 & J. M. Stuart* & 0.0 & 0.4 & 0.0 & b & $b$ & 0.00 & b & $b$ & b & b & b \\
\hline 営 & \multirow{2}{*}{\multicolumn{2}{|c|}{$\begin{array}{l}\text { Substitution } \ldots . . \\
\text { Total for Utility } \ldots\end{array}$}} & 4 & J. M. Stuart & 0.0 & 0.4 & 0.0 & b & b & 0.00 & b & b & b & b & b \\
\hline 䆘弯 & & & & & 1.4 & 5.7 & 1.0 & 12.40 & $\mathbf{b}$ & 6.90 & 3.53 & b & 22.83 & b. & 16.39 \\
\hline $\overrightarrow{\overline{8}} \overrightarrow{\mathrm{g}}$ & \multicolumn{15}{|c|}{ Georgia Power Company } \\
\hline$\stackrel{2}{\square}$ & Table 1 & $\ldots \ldots \ldots$ & 1 & Bowen & 1.0 & 1.0 & 0.0 & 0.40 & 0.00 & 7.19 & 0.74 & b & 8.33 & 0.00 & 10.34 \\
\hline Co & Table 1 & $\ldots \ldots \ldots$ & 2 & Bowen & 1.0 & 1.0 & 0.0 & 0.27 & 0.00 & 8.23 & 0.82 & b & 9.32 & 0.00 & 11.82 \\
\hline 晏焉 & Table 1 & $\ldots \ldots \ldots$ & 3 & Bowen & 1.0 & 1.0 & 0.0 & 2.06 & 0.00 & 9.11 & 0.61 & b & 11.78 & 0.00 & 12.37 \\
\hline$\stackrel{0}{\overrightarrow{0}} \stackrel{\overline{0}}{\Omega}$ & Table 1 & $\ldots \ldots \ldots$ & 4 & Bowen & 1.0 & 1.0 & 0.0 & 1.94 & 0.00 & 9.28 & 0.55 & b & 11.77 & 0.00 & 12.36 \\
\hline$\frac{1}{90}$ & Table 1 & $\ldots \ldots \ldots$ & 1 & Hammond & 0.0 & 0.5 & 0.0 & 1.45 & 0.00 & 0.00 & 0.53 & b & 1.98 & 0.00 & 15.84 \\
\hline$D$ & Table 1 & $\ldots \ldots \ldots$ & 2 & Hammond & 0.0 & 0.5 & 0.0 & 2.77 & 0.00 & 0.00 & 0.73 & b & 3.50 & 0.00 & 28.00 \\
\hline$\rightarrow$ & Table 1 & $\ldots \ldots \ldots$ & 3 & Hammond & 0.0 & 0.5 & 0.0 & 0.64 & 0.00 & 0.00 & 0.47 & b & 1.16 & 0.00 & 8.88 \\
\hline 焉 & Table 1 & $\ldots \ldots \ldots$ & 4 & Hammond & 1.0 & 0.5 & 0.0 & 1.00 & 0.00 & 22.00 & 0.45 & b & 23.45 & 0.00 & 40.57 \\
\hline 3 & Table 1 & $\ldots \ldots \ldots$ & 1 & McDonough & 1.0 & 0.5 & 0.0 & 2.35 & 0.00 & 9.18 & 0.62 & b & 12.15 & 0.00 & 40.61 \\
\hline 覀 & Table 1 & $\ldots \ldots \ldots$ & 2 & McDonough & 1.0 & 0.5 & 0.0 & 2.34 & 0.00 & 8.47 & 0.48 & b & 11.29 & 0.00 & 37.73 \\
\hline$\frac{2}{3}$ & Table 1 & $\ldots \ldots \ldots$ & 1 & Wansley * & 0.5 & 0.3 & 0.0 & 2.51 & 0.00 & 9.13 & 0.77 & b & 12.41 & 0.00 & 24.37 \\
\hline$\stackrel{\mathrm{g}}{\overrightarrow{\mathrm{g}}}$ & Table 1 & $\ldots \ldots \ldots$ & 2 & Wansley * & 0.5 & 0.3 & 0.0 & 2.15 & 0.00 & 5.95 & 0.59 & b & 8.69 & 0.00 & 17.06 \\
\hline $\begin{array}{l}5 \\
0 \\
0\end{array}$ & Table 1 & $\ldots \ldots \ldots$ & 1 & Yates (d) & 0.0 & 0.7 & 1.0 & 17.00 & 2.00 & 0.00 & 0.78 & b & 17.78 & 2.00 & 145.14 \\
\hline $\overrightarrow{0}$ & Table 1 & $\ldots \ldots \ldots$ & 2 & Yates & 0.0 & 0.7 & 0.0 & 1.98 & 0.00 & 0.00 & 0.47 & b & 2.45 & 0.00 & 20.00 \\
\hline & Table 1 & $\ldots \ldots \ldots$ & 3 & Yates & 0.0 & 0.7 & 0.0 & 1.53 & 0.00 & 0.00 & 0.40 & $b$ & 1.93 & 0.00 & 15.76 \\
\hline & Table 1 & $\ldots \ldots \ldots$ & 4 & Yates & 1.0 & 0.7 & 0.0 & 1.59 & 0.00 & 2.07 & 0.40 & $b$ & 4.06 & 0.00 & 25.98 \\
\hline & Table 1 & $\ldots \ldots \ldots$ & 5 & Yates & 1.0 & 0.7 & 0.0 & 1.36 & 0.00 & 2.07 & 0.33 & b & 3.76 & 0.00 & 24.06 \\
\hline & Table 1 & $\ldots \ldots \ldots$ & 6 & Yates & 1.0 & 0.7 & 0.0 & 1.82 & 0.00 & 6.13 & 0.85 & $b$ & 8.80 & 0.00 & 21.79 \\
\hline
\end{tabular}


Table C2. Cost of Phase I Compllance for Selected Units, by Utility (Continued)

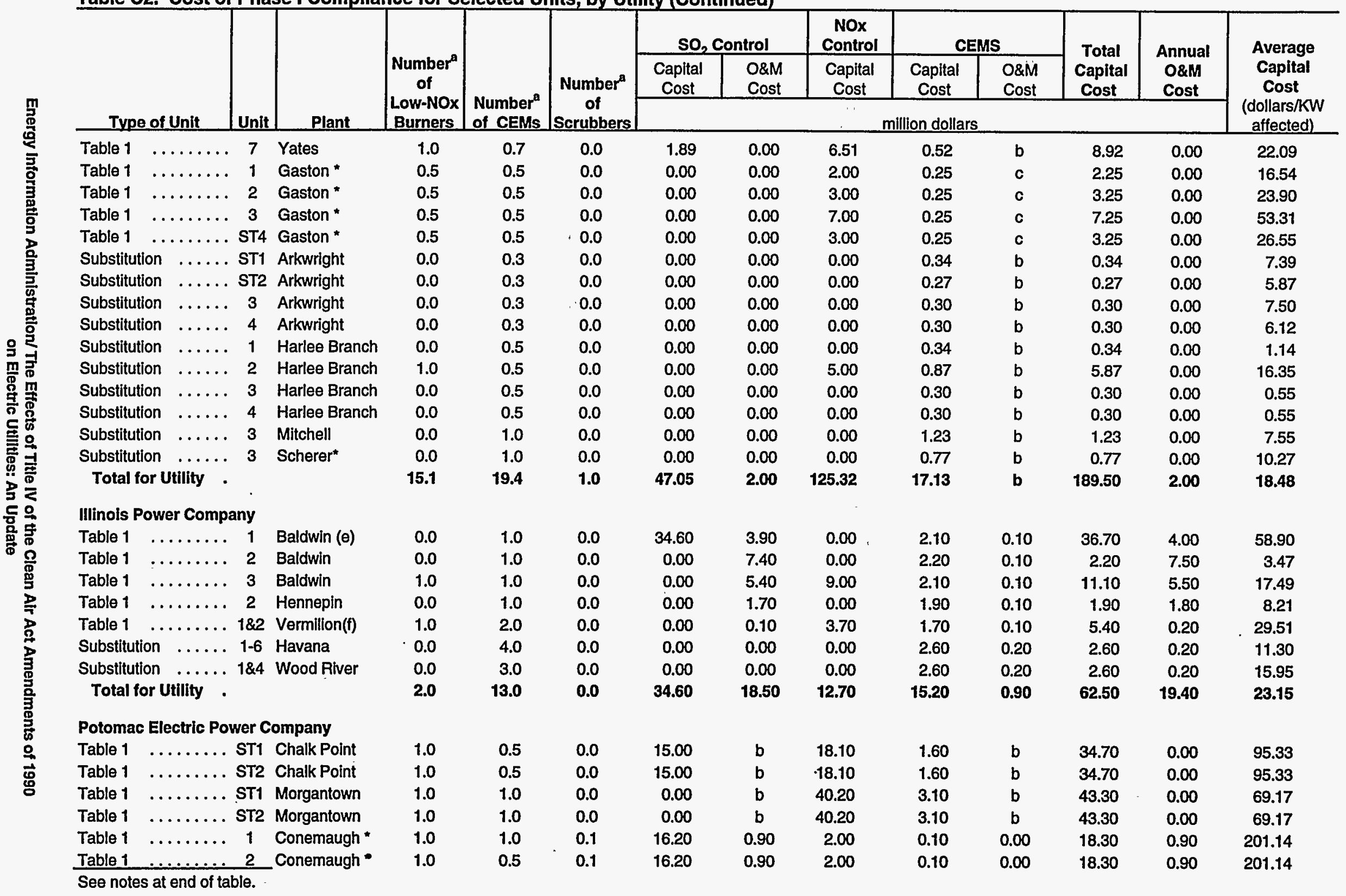


Table C2. Cost of Phase I Compliance for Selected Units, by Utility (Continued)

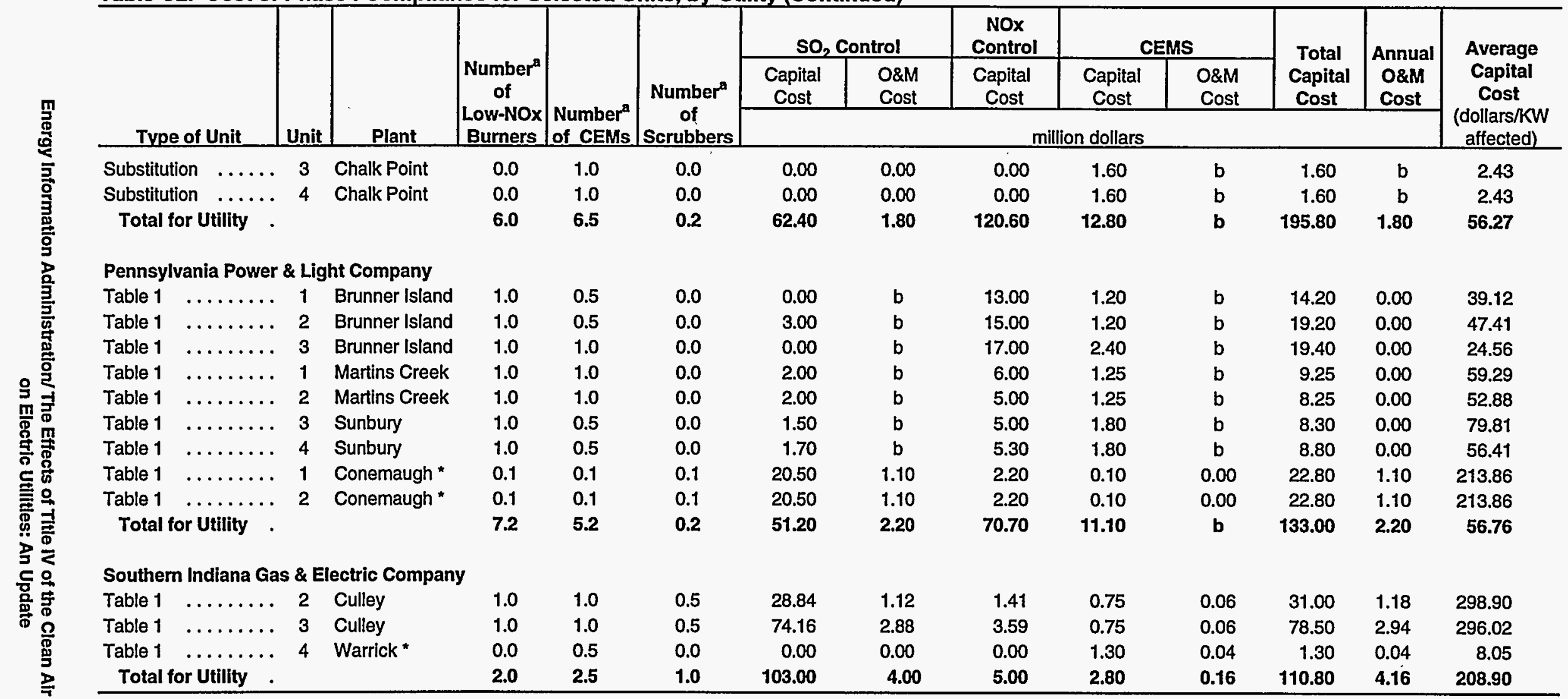

Note: Totals may not equal sum of individual components because of rounding.

${ }^{a} A$ fractional value indicates that ownership of equipment was allocated across more than 1 unit.

${ }^{\mathrm{b}}$ Costs not estimated.

Estimated to be negligible by utility.

Includes only one-haif of scrubber capital costs. The other half is paid by the Department of Energy as a demonstration project.

Installation of the scrubber for the Baldwin 1 unit was suspended in 1992.

Vermillion 1 is a substitution unit.

*Partially owned unit.

CEMS = Continuous emission monitoring systems.

$\mathrm{NO}_{x}=$ Nitrogen oxides.

$\mathrm{SO}_{2}=$ Sulfur dioxide.

$\mathrm{KW}=$ Kilowatts.

Sources: Personal contact with Illinois Power, Pennsylvania Power and Light, Potomac Electric Power, Cincinnati Gas and Electric, Georgia Power, and Southern Indiana Gas and Electric. 



\section{Glossary}

Acid Rain: Also called acid precipitation or acid deposition, acid rain is precipitation containing harmful amounts of nitric and sulfuric acids formed primarily by nitrogen oxides and sulfur oxides released into the atmosphere when fossil fuels are burned. It can be wet precipitation (rain, snow, or fog) or dry precipitation (absorbed gaseous and particulate matter, aerosol particles, or dust). Acid rain has a pH below 5.6. Normal rain has a pH of about 5.6 , which is slightly acidic. The term $\mathrm{pH}$ is a measure of acidity or alkalinity and ranges from 0 to 14 . A pH measurement of 7 is regarded as neutral. Measurements below 7 indicate increased acidity, while those above indicate increased alkalinity.

Allowance: One $\mathrm{SO}_{2}$ allowance permits one ton of $\mathrm{SO}_{2}$ emissions.

Anthracite: A hard, black lustrous coal, often referred to as hard coal, containing a high percentage of fixed carbon and a low percentage of fixed volatile matter.

Ash: Impurities consisting of silica, iron, alumina, and other noncombustible matter that are contained in coal. Ash increases the weight of the coal, adds to the cost of handling, and can affect its burning characteristics. Ash content is measured as a percent by weight of coal on an "as received" or a "dry" (moisture-free, usually part of a laboratory analysis) basis.

Ash Fusion Temperature: The temperature at which ash from coal melts.

Bituminous Coal: The most common coal. It is dense and black (often with well-defined bands of bright and dull material). Its moisture content usually is less than 20 percent. It is used for generating electricity, making coke, and space heating.

Boiler: A device for generating steam for power, processing, or heating purposes or for producing hot water for heating purposes or hot water supply. Heat from an external combustion source is transmitted to a fluid contained within the tubes in the boiler shell. This fluid is delivered to an end-use at a desired pressure, temperature, and quality.

Bureau of Mines, District 1: Maryland - All mines in the State. Pennsylvania - All mines in the following counties:
Bedford, Blair, Bradford, Cambria, Cameron, Centre, Clarion, Clearfield, Clinton, Elk, Forest, Fulton, Huntingdon, Jefferson, Lycoming, McKean, Mifflin, Potter, Somerset, and Tioga. Selected mines in the following counties: Armstrong County (part), all mines east of the Allegheny River, and those mines served by the Pittsburgh and Shawmut Railroad located on the west bank of the river; Fayette County (part), all mines located on and east of the line of Indian Creek Valley branch of the Baltimore \& Ohio Railroad; Indiana County (part), all mines not served by the Saltsburg branch of the Consolidated Railroad Corporation; and Westmoreland County (part), all mines served by the Consolidated Rail Corporation from Torrance, east. West Virginia - All mines in the following counties: Grant, Mineral, and Tucker.

Bureau of Mines District 2: Pennsylvania - All mines in the following counties: Allegheny, Beaver, Butler, Greene, Lawrence, Mercer, Venango, and Washington. Selected mines in the following counties: Armstrong County (part), all mines west of the Allegheny river except those mines served by the Pittsburgh \& Shawmutt Railroad; Fayette County (part), all mines except those on and east of the line of Indian Creek. Valley branch of the Baltimore \& Ohio Railroad; Indiana County (part), all mines served by the Saltsburg branch of the Consolidated Rail Corporation; and Westmoreland County (part), all mines except those served by the Consolidated Rail Corporation from Torrance, east.

Btu (British Thermal Unit): A standard unit for measuring the quantity of heat energy equal to the quantity of heat required to raise the temperature of 1 pound of water by 1 degree Fahrenheit.

CAAA90: The Clean Air Act Amendments of 1990.

Capital Costs: The costs of the long-term productive assets of a utility including scrubbers and continuous emissions monitors.

Coal: A black or brownish-black solid combustible substance formed by the partial decomposition of vegetable matter without access to air. The rank of coal, which includes anthracite, bituminous coal, subbituminous coal, and lignite, is based on fixed carbon, volatile matter, and heating value. Coal rank indicates the 
progressive alternation from lignite to anthracite. Lignite contains approximately 9 million to 17 million Btu per ton. The contents of subbituminous and bituminous coal range from 16 million to 24 million Btu per ton and from 19 million to 30 million Btu per ton, respectively. Anthracite contains approximately 22 million to 28 million Btu per ton.

Low-sulfur coal: The EIA sulfur content category of coal with less than 0.60 pounds of sulfur per million Btu.

Medium-sulfur coal: The EIA sulfur content category of coal with 0.60 to 1.67 pounds of sulfur per million Btu.

High-sulfur coal: The EIA sulfur content category of coal with greater than 1.67 pounds of sulfur per million Btu.

Compensating Unit: A unit designated by a Table 1 unit that reduced its utilization below its baseline. The compensating unit provides compensating generation to account for the reduced utilization of the Table 1 unit.

Consumption (Fuel): The amount of fuel used for gross generation, providing standby service, start-up and/or flame stabilization.

Continuous Emission Monitor (CEM): A device that approximates a continuous measurement of certain characteristics of a gas by making separate measurements frequently. For compliance with the CAAA90, the measurements must be taken at least every 15 minutes.

Extractive Continuous Emission Monitor: A CEM that draws exhaust gas away from the combustion system to the measurement equipment through special ducts.

In Situ Continuous Emission Monitor: A CEM that makes measurements directly in the flue or exhaust pipe.

Cost: The amount paid to acquire resources, such as plant and equipment, fuel, or labor services.

Demand-Side Management: The planning, implementation, and monitoring of utility activities that are designed to influence consumer use of electricity in ways that will produce desired changes in a utility's load shape, including direct Load Control, Interruptible Load, and Conservation and Other Demand-Side Management categories. Demand-Side Management includes utility- administered programs that are designed to reduce load growth, and any other programs designed for strategic load growth.

Dry Dust Baghouse Collector: A fabric filter that collects the dry particulate matter as the cooled flue gas passes through the filter material.

Electric Utility: A corporation, person, agency, authority, or other legal entity or instrumentality that owns and/or operates facilities within the United States, its territories, or Puerto Rico for the generation, transmission, distribution, or sale of electric energy primarily for use by the public and files forms listed in the Code of Federal Regulations, Title 18, Part 141. Facilities that qualify as cogenerators or small power producers under the Public Utility Regulatory Policies Act (PURPA) are not considered electric utilities.

Electrostatic Precipitator (ESP): A unit comprised of a series of parallel vertical plates through which the flue gas passes. It electrically charges the ash particles in the flue gas to collect and remove them.

Energy: The capacity for doing work as measured by the capability of doing work (potential energy) or the conversion of this capability to motion (kinetic energy). Energy has several forms, some of which are easily convertible and can be changed to another form useful for work. Most of the world's convertible energy comes from fossil fuels that are burned to produce heat that is then used as a transfer medium to mechanical or other means in order to accomplish tasks. Electrical energy is usually measured in kilowatthours, while heat energy is usually measured in British thermal units.

Facility: An existing or planned location or site at which prime movers, electric generators, and/or equipment for converting mechanical, chemical, and/or nuclear energy into electric energy are situated, or will be situated. A facility may contain more than one generator of either the same or different prime mover type.

Federal Energy Regulatory Commission (FERC): A quasi-independent regulatory agency within the Department of Energy having jurisdiction over interstate electricity sales, wholesale electric rates, hydroelectric licensing, natural gas pricing, oil pipeline rates, and gas pipeline certification.

Flue Gas Desulfurization Unit (Scrubber): Equipment used to remove sulfur oxides from the combustion gases of a boiler plant before discharge to the atmosphere. Chemicals, such as lime, are used as the scrubbing media. 
Flue Gas Particulate Collectors: Equipment used to remove fly ash from the combustion gases of a boiler plant before discharge to the atmosphere. Particulate collectors include electrostatic precipitators, mechanical collectors (cyclones), fabric filters (baghouses), and wet scrubbers.

Fly Ash: Particulate matter from coal ash in which the particle diameter is less than $1 \times 10^{-4}$ meter. This is removed from the flue gas using flue gas particulate collectors such as fabric filters and electrostatic precipitators.

Fossil Fuel: Any naturally occurring organic fuel, such as petroleum, coal, and natural gas.

Fouling: The formation of high temperature bonded deposits on convective heat absorbing surfaces that are not exposed to radiant heat.

Fuel Expenses: These costs include the fuel used in the production of steam or driving another prime mover for the generation of electricity. Other associated expenses include unloading the shipped fuel and all handling of the fuel up to the point where it enters the first bunker, hopper, bucket, tank, or holder in the boiler-house structure.

Generating Unit: Any combination of physically connected generator(s), reactor(s), boiler(s), combustion turbine(s), or other prime mover(s) operated together to produce electric power.

Generation (Electricity): The process of producing electric energy from other forms of energy; also, the amount of electric energy produced, expressed in watthours (Wh).

Gross Generation: The total amount of electric energy produced by the generating units at a generating station or stations, measured at the generator terminals.

Net Generation: Gross generation less the electric energy consumed at the generating station for station use.

Generator: A machine that converts mechanical energy into electrical energy.

Generator Nameplate Capacity: The full-load continuous rating of a generator, prime mover, or other electric power production equipment under specific conditions as designated by the manufacturer. Installed generator nameplate rating is usually indicated on a nameplate physically attached to the generator.
Gigawatt (GW): One billion watts of capacity.

Greenfield Unit: A newly constructed generating unit.

Hardgrove Grindability Index (HGI): A measure of the relative ease with which coal can be pulverized or ground. Higher grindability indicates coal which are easier to grind.

Kilowatt (kW): One thousand watts of capacity.

Kilowatthour (kWh): One thousand watthours.

Lignite: A brownish-black coal of low rank with high inherent moisture and volatile matter (used almost exclusively for electric power generation). It is also referred to as brown coal.

Low-NO $\mathrm{N}_{x}$ Burners: Burners that utilize special arrangements of fuel and air injection ports, which reduce the formation of $\mathrm{NO}_{x}$ during combustion.

Megawatt (MW): One million watts of capacity.

Megawatthour (MWh): One million watthours of electric energy.

$\mathrm{NO}_{\mathrm{x}}$ : Nitrogen oxides.

Natural Gas: A naturally occurring mixture of hydrocarbon and nonhydrocarbon gases found in porous geological formations beneath the earth's surface, often in association with petroleum. The principal constituent is methane.

Opacity: The degree of imperviousness to the passage of light.

Operations and Maintenance Costs: Operations costs are the components of power production that incur cost for operations that are directly related to producing electricity. The major item is almost always fuel that has to be burned to generate the electricity. Maintenance costs are the portion of operating expenses consisting of labor, materials, and other direct and indirect expenses incurred for preserving the operating efficiency and/or physical condition of utility plants used for power production, transmission, and distribution of energy.

Petroleum: A mixture of hydrocarbons existing in the liquid state found in natural underground reservoirs, often associated with gas. Petroleum includes fuel oil No. 2,No. 4, No. 5, No. 6; topped crude; Kerosene; and jet fuel. 
Petroleum (Crude Oil): A naturally occurring, oily, flammable liquid composed principally of hydrocarbons. Crude oil is occasionally found in springs or pools but usually is drilled from wells beneath the earth's surface.

Plant: A facility at which are located prime movers, electric generators, and auxiliary equipment for converting mechanical, chemical, and/or nuclear energy into electric energy. A plant may contain more than one type of prime mover. Electric utility plants exclude facilities that satisfy the definition of a qualifying facility under the Public Utility Regulatory Policies Act of 1978.

Plant-Use Electricity: The electric energy used in the operation of a plant. This energy total is subtracted from the gross energy production of the plant; for reporting purposes the plant energy production is then reported as a net figure. The energy required for pumping-storage plants is, by definition, subtracted, and the energy production for these plants is then reported as a net figure.

Pulverizers: Mills of various designs used to finely grind the coal which is swept from the mills by air for pneumatic transport directly to the burners.

$\mathrm{SO}_{2}$ : Sulfur dioxide.

Slagging: The formation of molten, partially fused resolidified deposits on furnace walls or other surface exposed to radiant heat.
Subbituminous Coal: A dull black coal of rank intermediate between lignite and bituminous.

Substitution Unit: A unit brought into Phase I to assist a Table 1 unit in meeting emissions reduction obligations. Utilities may make cost-effective emissions reductions at the substitution unit instead of at the Table 1 unit by achieving the same overall emissions reductions that would have occurred without the participation of the substitution unit.

Sulfur: One of the elements present in varying quantities in coal which contributes to environmental degradation when coal is burned. In terms of sulfur content by weight, coal is generally classified as low (less than or equal to 1 percent), medium (greater than 1 percent and less than or equal to 3 percent), and high (greater than 3 percent). Sulfur content is measured as a percent by weight of coal on an "as received" or a "dry" (moisturefree, usually part of a laboratory analysis) basis.

Watthour (Wh): An electrical energy unit of measure equal to 1 watt of power supplied to, or taken from, an electric circuit steadily for 1 hour. 